\title{
Identification of Energy
}

Conservation Research

Opportunities: A Review and

Synthesis of the Literature
W. J. Hopp
R. E. Williford
G. J. Hane
T. A. Williams
S. G. Hauser
W. B. Ashton
W. E. Gurwell

March 1982

Prepared for the U.S. Department of Energy under Contract DE-AC06-76RLO 1830

Pacific Northwest Laboratory Operated for the U.S. Department of Energy by Battelle Memorial Institute 


\title{
DISCLAIMER
}

This report was prepared as an account of work sponsored by an agency of the United States Government. Neither the United States Government nor any agency thereof, nor any of their employees, makes any warranty, express or implied, or assumes any legal liability or responsibility for the accuracy, completeness, or usefulness of any information, apparatus, product, or process disclosed, or represents that its use would not infringe privately owned rights. Reference herein to any specific commercial product, process, or service by trade name, trademark, manufacturer, or otherwise, does not necessarily constitute or imply its endorsement, recommendation, or favoring by the United States Government or any agency thereof. The views and opinions of authors expressed herein do not necessarily state or reflect those of the United States Government or any agency thereof.

\author{
PACIFIC NORTHWEST LABORATORY \\ operated by \\ BATTELLE \\ for the \\ UNITED STATES DEPARTMENT OF ENERGY \\ under Contract DE-AC06-76RLO 1830
}

\begin{tabular}{|c|c|}
\hline \multicolumn{2}{|c|}{ Printed in the United States of America } \\
\hline \multirow{2}{*}{\multicolumn{2}{|c|}{$\begin{array}{c}\text { Available from } \\
\text { National Technical Information Service }\end{array}$}} \\
\hline & \\
\hline \multirow{3}{*}{\multicolumn{2}{|c|}{$\begin{array}{c}\text { United States Department of Commerce } \\
5285 \text { Port Royal Road } \\
\text { Springfield, Virginia 22151 }\end{array}$}} \\
\hline & \\
\hline & \\
\hline \multirow{2}{*}{\multicolumn{2}{|c|}{$\begin{array}{l}\text { NTIS Price Codes } \\
\text { Microfiche A01 }\end{array}$}} \\
\hline & \\
\hline \multicolumn{2}{|c|}{ Printed Copy } \\
\hline & Price \\
\hline Pages & Codes \\
\hline 001-025 & $\mathrm{A} 02$ \\
\hline 026-050 & $\mathrm{A} 03$ \\
\hline $051-075$ & A04 \\
\hline $076-100$ & A05 \\
\hline $101-125$ & A06 \\
\hline $126-150$ & A07 \\
\hline $151-175$ & $\mathrm{~A} 08$ \\
\hline $176-200$ & A09 \\
\hline $201-225$ & A010 \\
\hline $226-250$ & A011 \\
\hline $251-275$ & A012 \\
\hline $276-300$ & A013 \\
\hline
\end{tabular}




\title{
33679000597551
}

IDENTIFICATION OF ENERGY CONSERVATION RESEARCH

OPPORTUNITIES: A REVIEW AND SYNTHESIS

OF THE LITERATURE
W. J. Hopp
G. J. Hane
W. E. Gurwe 11
S. G. Hauser
R. E. Williford
T. A. Williams
W. B. Ashton

March 1982

\begin{abstract}
Prepared for
Energy Conversion and Utilization Technologies Division Office of Energy Systems Research Conservation and Renewable Energy U.S. Department of Energy under Contract DE-AC06-76RLO 1830
\end{abstract}

Pac ific Northwest Laboratory Richland, Washington 99352 


\section{ACKNOWLEDGMENTS}

The research staff of this project would like to thank Theodore willke and W. Bradford Ashton for the ir conceptual guidance and managerial support of this effort. We also thank Benjamin Johnson for $h$ is technical overview of our work. Finally, we extend our appreciation to our sponsors, E. Karl Bastress and Michael Shapiro of the Department of Energy, for the open-minded and enthusiastic support they gave us throughout this project. 
• 


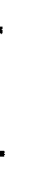




\section{PREFACE}

This report provides a review and synthesis of several significant studies that were conducted to assess R\&D needs and opportunities for advanced energy conservation systems. The authors feel that it is important to emphasize that this effort was not intended to be a comprehensive review of the energy conservation research literature. The purpose of this study was primarily to provide information that could be used in identifying candidate R\&D opportunities for a companion report, An Overview of Energy Conservation Research Opportunities. It is also important to note that the studies that were reviewed in each of the energy end-use areas are not necessarily the most widely known or most complete studies that have been performed in those areas. Rather, this report provides a preliminary overview of a representative sample of 38 energy conservation research opportunities studies using a consistent critical review format. This format allows a comparison of the types of information typically provided in the reports and initial development of a master catalog of the energy conservation and research opportunities that have been identified by a variety of sources.

This report is one of a series of studies in support of the research planning effort for the Division of Energy Conversion and Utilization Technologies in the U.S. Department of Energy. Other documents in the series contain assessments of energy conservation technology areas, methods to appraise research projects for support, and data reference sources. Publications from this project include:

Hopp, W. et a 1. 1981. An Overview of Energy Conservation Research Opportunities. PNL-3944, Pacific Northwest Laboratory, Richland, Washington.

Hopp, W. et a 1. 1981. An Overview of Energy Conservation Research Opportunities. Executive Summary. PNL-3944 Ex. Sum., Pacific Northwest Labor-

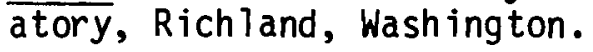

Imhoff, C. H. et a T. 1982. U.S. Energy Conversion and Use Characteristics. PNL-4075, Pac ific Northwest Laboratory, Richland, Washington.

U.S. Department of Energy. 1981. The 1981 Work Element Appraisal. DOE/CE0024, U.S. Department of Energy, Washington, D.C. 


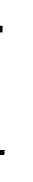


CONTENTS

PREFACE

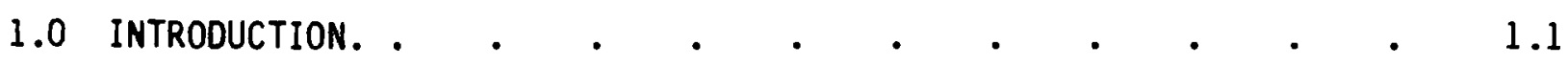

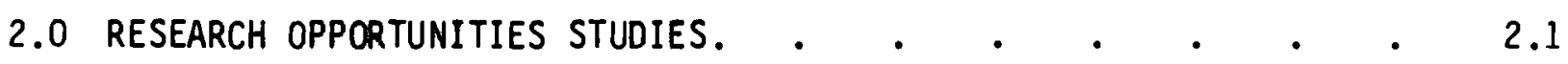

3.0 ENERGY CONSERVATION RESEARCH OPPORTUNITIES. • • • • • • •

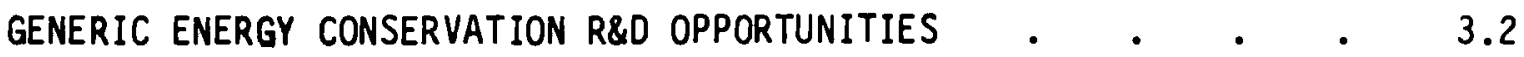

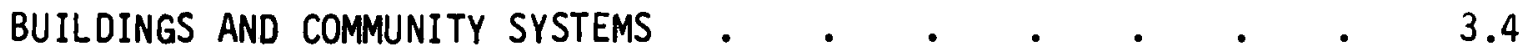

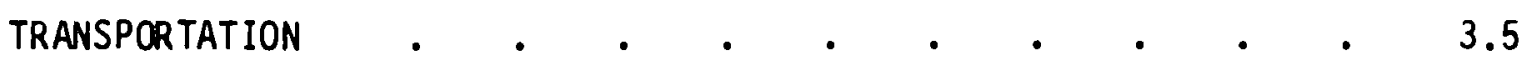

INDUSTRY • • • .

SUMMARY AND CONCLUSIONS •

APPENDIX A - TABLES OF ENERGY CONSERVATION R\&D OPPORTUNITIES . . A.1

APPENDIX B - CRITICAL REVIEWS.$\quad \cdot \quad \cdot \quad \cdot \quad \cdot \quad \cdot \quad \cdot \quad \cdot \quad B .1$

B.1 CRITICAL REVIEWS--FORMAT • . . . . . • . . . B. B

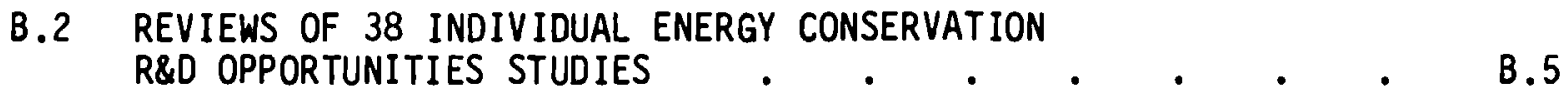

Report No. 1 - Environmental Considerations of Selected

Energy-Conserving Manufacturing Process

Options, by A.D. Little, Inc. • . . B.7

Report No. 2 - RD\&D for Energy Conservation Preliminary Identification in Iron and Steelmaking,

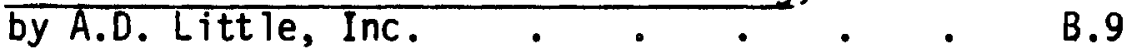

Report No. 3 - An Assessment of the Potential Impact of

Combustion Research on Internal Combustion

Engine Emissions and Fuel Consumption,

by Aerodyne Research, Inc. • • . . B.15

Report No. 4 - Efficient Use of Energy: AIP Conference Proceedings No. 25, by American Institute of Physics . . . . . . . B.27

Report No. 5 - Research Needs Report: Environmental and Conservation Research, by the American Soc iety of Mechanica T Engineers $\quad$ B. 35 
Report No. 6 - Research Needs Report: Fundamental Research Needs, by the American Soc iety of Mechanical Engineers . . . . B.37

Report No. 7 - Research and Development Needs for Transportation, by C. J. Anderson

Report No. 8 - Developing a Maximum Energy Efficiency Improvement Target for SIC 28: Chemicals and Allied Products, by Battelle Columbus Laboratories

Report No. 9 - Implementation of Energy Conservation Technology in the Steel Industry, by Battelle Columbus Laboratories . .

Report No. 10 - Energy Conservation in Industry: The Present Approach, The Future Opportunities, by C. A. Berg. . . . . .

Report No. 11 - Future Raw Materials and Energy Use in Industry - A Research Agenda, by the Brookhaven National Laboratories . .

Report No. 12 - Energy in Transition 1985-2010, by Committee on Nuclear and Alternative Energy Systems

Report No. 13 - "Environmental and Conservation Research Needs in the Eighties," by C.J. Cremers . B.87

Report No. 14 - Department of Energy Program Objectives, Fluid Waste Heat Recovery and Utilization, by the Department of Energy . . . . . . .

Report No. 15 - Report of the Proceedings of the DOE Workshop on Energy Conservation in the Textile Industry, by the Department of Energy

Report No. 16 - Research Workshop on Energy Conservation through Enhanced Heat Transfer, Department of Energy . . .

Report No. 17 - Agricultural Processing Industry Workshop on Energy Conservation, by the Energy Research and Development Administration

Report No. 18 - ERDA Workshop on Energy Conservation in Agricultural Production, by the Energy Research and Development Admin istration 
Report No. 19 - ERDA Workshop on Fluid Waste Heat Recovery and Utilization, by the Energy Research and Deve lopment Administration . .

Report No. 20 - ERDA Workshop on High Temperature Waste Heat Recovery and Utilization, by the Energy Research and Development Administration

Report No. 21 - Federal Council for Science and Technology, Needs for Energy-Re lated Materials Research and Development. Vol. I Near-Term Energy Program, by the Energy Task Group, Committee on

Report No. 22 - Basic Research in Engineering: Advanced Industrial Technology, by the Engineering Societies Commission on Energy

Report No. 23 - Basic Research in Engineering, Fluid Dynamics and Thermal Processes, by the Engineering Societies Commission on Energy

Report No. 24 - Energy Conservation in the Paper and Allied Products Industry, Phase 1, by the Georgia Institute of Techno logy .

Report No. 25 - IEA Steel R\&D Report, Final Report, by Gordian Associates

Report No. 26 -"Fuel Conservation and Applied Research," by J. Grey, G. W. Sutton, and M. 2lotnick .

Report No. 27 - Basic Research Needs in Energy Conservation, by J. M. Hollander

Report No. 28 - Tribology: Research and Development Needs in Advanced Energy Technology, by R. M. Johnson . . . •

Report No. 29 - "Energy Conservation in Road Transportation Through Lubrication Technology," by E. E. Klaus.

Report No. 30 - Reducing Fuel Usage Through Applications of Conservation and Solar Energy, by K. E. May and D. W. Hooker . 
Report No. 31 - An Agenda for Research and Development on End-Use Energy Conservation, by the MITRE Corporation . . . . . B.181

Report No. 32 - Residential Energy Conservation, by the Office of Technology Assessment . . B.183

Report No. 33 -"Combustion R\&D - Key to Our Energy Future", by A. K. Oppenhe im and F. J. Weinburg . . B.185

Report No. 34 - Strategy for Energy Conservation Through Tribology, by 0. Pinkus and 0. Wi lcock . B.187

Report No. 35 - Implementation of Energy Conservation \begin{tabular}{ll} 
Technology in the Paper and Pulp Industry, & \\
\hline by Resource Planning Associates . . . B . B . B
\end{tabular}

Report No. 36 - Our Energy: Regaining Control, by M. H. Ross and R. H. Williams . . . B.201

Report No. 37 - Energy in America's Future: The Choices Before Us, by S. H. Schurr, et. a1. . . B.205

Report No. 38 - Materials Technology Assessment for Stirling Engine, by J. R. Stephens, W. R. Witzke, G. K. Watson, J. R. Johnson, and W. J. Croft

B.3 - BIBLIOGRAPHY OF ENERGY CONSERVATION RESEARCH OPPORTUNITIES STUDIES 
TABLES

2.1 Sumary of Research Opportunities Studies . • • • • • 2.2

2.2 Categorization of Research Opportunities Studies by End-Use

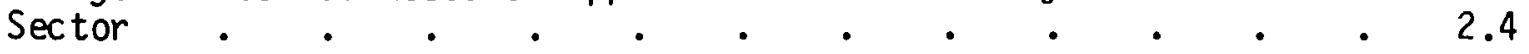

2.3 Categorization of Research Opportunities Studies by General Research Area . . . . . . . . . 2.4

A.1 Generic Energy Conservation R\&D Opportunities . . . . A.2

A.2 Examples of R\&D Opportunities in Technologies Across End-Use Sectors . . . . . . . . . A.10

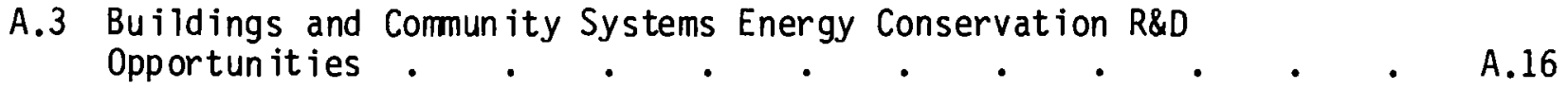

A.4 Transportation Energy Conservation R\&D Opportunities . . - . A.21

A.5 Industrial Energy Conservation R\&D Opportunites . . . . . A.25 


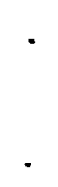




\subsection{INTRODUCTION}

Identifying research opportunities that will promote more efficient energy use is an immense task that many authors have addressed from various perspectives and with a variety of results. Consequently, a vast diversity of literature concerning opportunities for energy conservation research exists. A representative sample of this literature is reviewed with two purposes in mind: first, to synthesize the studies' results to provide a broad list of the suggested research ideas and second, to produce an overview of the studies to guide the use of this literature. This list forms a pool of candidates that can be investigated further and that is drawn upon in the companion report, An Overview of Energy Conservation Research Opportunities (Hopp et al. 1981). These reports are sponsored by and written in support of the Energy Conversion and Utilization Technologies Program of the U.S. Department of Energy (DOE).

In th is report 38 studies of energy conservation research opportunities are reviewed. A list of the titles and authors for these studies is presented in the Table of Contents. Note that this effort was not intended to be a comprehensive review of the literature. Many other studies identify energy conservation research opportunities, and a more extensive bibliography including 50 additional reports has been developed by the PNL assessment staff and is included in Appendix B. However, the 38 studies chosen for review include many of the major efforts in the identification of energy conservation research and development (R\&D) opportunities and provide a representative sample of the types of studies that have been performed. The sample includes studies that focus on specific energy use (e.g., auto transport), as well as studies that focus on specific types of research (e.g., materials science). The sample also includes studies that $c$ an be further contrasted in terms of long-term vs. shortterm projects, evolutionary vs. revolutionary ideas, generic vs. processspecific activities, and technology base research vs. hardware development. Each of these perspectives contributes toward assuring coverage of the breadth of energy conservation R\&D opportunities.

In reviewing the 38 studies the PNL assessment staff cormented on the documents through a predetermined review format, which is presented in 
Appendix B. In each review the technical or end-use focus is described, the research ideas identified in the study are listed, and a critical sumary is given. The reviews also indicate whether the studies present end-use consumption data, estimate potential energy savings, estimate times to commercialization, summarize existing research programs, or describe the identification methodology.

A consistent summary of the studies as a whole and of the suggested research ideas provides an insight into the work that has been done to date on identifying energy conservation research opportunities. The descriptions of the individual research ideas allow a comprehensive list of topics that have been identified in the literature to be synthesized and categorized. This list may not be well justified or may not necessarily consist of promising ideas, but is a broad and complete list because it is a combination of the lists prepared in the other studies. Also, identifying each study's focus enables topical areas that have and have not been adequately covered to be systematically reviewed. Th is review permits an assessment of technology areas that may need further analysis of energy conservation opportunities. Further, identifying specific types of information provided by each study allows its comprehensiveness to be compared to other similar efforts. It also allows the critical reviews to act as an annotated bibliography for persons reviewing the literature.

In Section 2.0 the various research studies are compared. In Section 3.0 the characteristics of an aggregated list of research ideas are discussed. The characteristics were collected from the research opportunities studies, which are included in Appendix A. Appendix A contains a compilation of energy conservation R\&D opportunities arranged by energy end-use applications. Appendix $B$ contains an outline of the format followed in writing the critical reviews of the studies, the individual study reviews and the extended bibliography of 88 studies that describe energy conservation research opportunities. 


\subsection{RESEARCH OPPORTUNITIES STUDIES}

The critical reviews of the 38 research opportunities studies examined in this report ind icate whether the following five types of information are presented in each document:

(1) reviews of energy consumption data

(2) estimates of the conservation potential of the technologies under consideration

(3) estimates of the commercialization dates or research times of the technologies

(4) sumaries of existing research programs relating to the technologies

(5) a description of the method for identifying energy conservation research opportunities used in the study.

In Table 2.1 the types of information and also the focus and the approximate number of research opportunities identified in each report are indicated. The first columns in this table refer to the numbering system used for the reports in the Table of Contents. This summary can serve as a guide to the usefulness of the various studies for different applications. It also allows some interesting comparisons and generalizations to be made about the studies.

The first characteristic that is apparent from the information in Table 2.1 is a correlation between the focus of the report and the level of specificity of the research opportunities identified in the report. The research opportunities in each report have been classified as "specific," "intermediate," and "genera 1." "Specific" research opportunities refer to ideas for which both particular technical problems relating to energy conservation have been identified and research solutions have been proposed. An example of this might be "development of longer-lasting titanium diboride cathodes to improve the efficiency of the aluminum smelting process." "Intermediate" refers to ideas for which particular problems or needed improvements have been identified, but for which research solutions have not been specified. An example might be 
TABLE 2.1. Summary of Research Opportunities Studies

\begin{tabular}{|c|c|c|c|c|c|c|c|c|}
\hline $\begin{array}{l}\text { Report } \\
\text { Number } \\
\text { from } \\
\text { Biblio. }\end{array}$ & $\begin{array}{c}\text { Focus } \\
\text { of Report }\end{array}$ & $\begin{array}{c}\begin{array}{c}\text { Reviews } \\
\text { End-Use } \\
\text { Consumption } \\
\text { Data }\end{array} \\
\end{array}$ & $\begin{array}{c}\text { Estimates } \\
\text { Conservation } \\
\text { Potential } \\
\text { of Technologies } \\
\end{array}$ & $\begin{array}{l}\text { Estimates Time to } \\
\text { Commercialization } \\
\text { of Technologies }\end{array}$ & $\begin{array}{c}\text { Summarizes } \\
\text { Existing } \\
\text { Research } \\
\text { Programs } \\
\end{array}$ & $\begin{array}{l}\text { Gives and } \\
\text { uses a Meth- } \\
\text { odology for } \\
\text { Identifying } \\
\text { Research } \\
\text { Opportunities }\end{array}$ & $\begin{array}{l}\text { Approximate } \\
\text { Number of } \\
\text { Research } \\
\text { Opportunties } \\
\text { Identified } \\
\end{array}$ & $\begin{array}{l}\text { Level of } \\
\text { Specificity } \\
\text { of Research } \\
\text { Opportunities }\end{array}$ \\
\hline 1 & Cement Industry & yes & no & no & no & partially & 4 & general/inter. \\
\hline 2 & Iron \& Steel Industry & yes & yes & yes & yes & yes & 30 & intermediate \\
\hline $\begin{array}{l}3 \\
4\end{array}$ & $\begin{array}{l}\text { Combustion Engines } \\
\text { Physics-Oriented Con- }\end{array}$ & no & no & no & no & no & 20 & intermediate \\
\hline 5 & $\begin{array}{l}\text { servation Research } \\
\text { Mech. Engineering R\&D }\end{array}$ & yes & no & no & no & yes & 75 & intermediate. \\
\hline & Needs & no & no & no & no & no & 10 & genera? \\
\hline 6 & Broad Conservation & & & & & & & \\
\hline & $R \& D$ & no & no & no & no & no & 6 & general \\
\hline 7 & Transportation Sector & yes & no & partially & no & no & 2 & general \\
\hline 8 & Chemicals Industry & yes & no & no & no & no & 3 & general/inter. \\
\hline 9 & Steel Industry & yes & yes & yes & yes & yes & 93 & specific \\
\hline $\begin{array}{l}10 \\
11\end{array}$ & $\begin{array}{l}\text { Iron \& Steel Industry } \\
\text { Industrial Energy Con- }\end{array}$ & yes & partially & partially & yes & no & 15 & medium \\
\hline & servation & no & no & no & no & no & 150 & specific/inter. \\
\hline $\begin{array}{l}12 \\
13\end{array}$ & $\begin{array}{l}\text { National Energy Scenarios } \\
\text { Mech. Engineering R\&D }\end{array}$ & yes & no & no & no & no & 50 & intermediate \\
\hline & Needs & no & no & no & no & no & 10 & general \\
\hline 14 & Fluid waste Heat Recovery & no & yes & yes & yes & no & 100 & specific \\
\hline 15 & Textiles Industry & no & yes & partially & yes & no & 40 & specific/inter. \\
\hline 16 & Heat Transfer & no & no & no & yes & no & 13 & intermedia te \\
\hline 17 & Agricuiture Industry & no & yes & yes & no & no & 90 & specific \\
\hline 18 & Agricultural Production & no & yes & yes & no & no & 110 & intermediate \\
\hline $\begin{array}{l}19 \\
20\end{array}$ & Fluid Waste Heat Recovery & no & yes & partially & no & no & 93 & specific/inter. \\
\hline & $\begin{array}{l}\text { High Temp. Waste Heat } \\
\text { Recovery }\end{array}$ & no & yes & partially & no & no & 15 & intermediate \\
\hline 21 & Materials & no & no & no & yes & no & 19 & general/inter. \\
\hline $\begin{array}{l}22 \\
23\end{array}$ & $\begin{array}{l}\text { Advanced Industrial Tech. } \\
\text { Fluid Dynamics \& Thermal }\end{array}$ & partially & no & no & no & yes & 110 & intermediate \\
\hline & Process & no & no & no & no & yes & 100 & specific \\
\hline 24 & Paper and. Allied Products & no & partially & no & no & no & 2 & specific \\
\hline 25 & Steel Industry & no & no & partially & no & no & 20 & general \\
\hline 26 & Automobile R\&D & yes & yes & no & no & yes & 12 & intermediate \\
\hline 27 & General Basic R\&D Needs & no & no & no & no & no & 30 & inter/general \\
\hline 28 & Tribology & no & no & no & yes & no & 9 & intermediate \\
\hline 29 & Lubricant Technology & yes & yes & no & partially & partially & 5 & intermediate \\
\hline $\begin{array}{l}30 \\
31\end{array}$ & $\begin{array}{l}\text { Industrial Conservation } \\
\text { Conservation Budget/ }\end{array}$ & yes & no & no & no & no & 2 & general \\
\hline & Recommendation & yes & partially & no & no & no & 10 & intermediate \\
\hline 32 & Residential Energy Con- & & & & & & & \\
\hline & servation & yes & no & yes & yes & partially & 50 & intermediate \\
\hline 33 & Combustion Processes & no & no & no & yes & no & 5 & general \\
\hline 34 & Tribology & yes & yes & partially & partially & yes & 40 & intermediate \\
\hline 35 & Paper and Pulp Industry & yes & yes & yes & no & yes & 46 & general/specific \\
\hline 36 & Space Heat, Cogener., Auto & 0 yes & no & no & no & yes & 10 & specific/general \\
\hline 37 & National Energy Policy & yes & partially & no & no & no & 20 & inter/general \\
\hline 38 & Stirling Engines & no & no & no & no & yes & 2 & specific \\
\hline
\end{tabular}


"decreased rolling resistance in automotive tires." "General" research opportunities merely refer to ideas in which end-use areas or topics where research would presumably promote energy conservation have been identified. Examples might be research into "space heating of buildings" or "tribology." The major end-use or research focus of each report is also identified in Table 2.1. In some reports a particular area of energy use, such as the agricultural industry, is examined, whereas a particular generic research area, such as fluid dynamics, is the focus for others. In still other reports an attempt is made to cover the entire energy end-use spectrum and to consider all types of generic research. A review of Table 2.1 clearly indicates that the studies with very limited focuses, for example, to a particular industry or technology, tended to be much more specific in their descriptions and listed more research opportunities. The studies that attempted to cover a broad scope of end uses or technologies tended to be much more general in their discussions and listed fewer broad areas of research opportunities. This pattern is not surprising because identifying research opportunities in energy conservation is so broad that comprehensive and in-depth coverage is a difficult task.

Cataloging the research opportunities studies by their area of focus is another way to systematize the literature search process and to identify gaps in the literature. In Table 2.2 the studies are categorized according to the ir end-use focus. This sumary shows that the buildings and transportation enduse sectors are we 11 represented in the sample of 38 studies reviewed. Reports from the major manufacturing industries plus agriculture were also included in the reviews; however, because industry is composed of diverse technology areas, on ly a few studies describe a specific industry.

Table 2.3 categorizes the research opportunities studies according to the ir generic research focus. Whereas the list in Table 2.3 is far from exhaustive, it does include most of the major research areas generally considered to be applicable to energy conservation.

Table 2.1 permits further overview of the literature by providing an indication of which of the five types of information previously mentioned are included in the studies. The number of studies either completely or only partially including the corresponding information is sumarized in the following list: 
TABLE 2.2. Categorization of Research Opportunities Studies by End-Use Sector

End-Use Focus

Buildings and Community Systems

Transportation

Industry

Chemicals

Primary Metals

Pulp and Paper

Stone, Clay, and Glass

Food Processing

Textiles

Agriculture

General Industry
Report Numbers

$12,32,36$ $3,4,7,12,21,26,29$
$33,34,36$
8
$2,9,25$
24,35
1
$17,18,19$
15
$17,18,19$
$10,11,12,21,22$,
36

TABLE 2.3. Categorization of Research Opportunities Studies by General Research Area

Genera 7 Research Area

Tribology (Material, Lubrication)

Materials (Corrosion, Composites, Net Shape, Processes,...)

Heat Transfer/Waste Heat Recovery

Fluid Mechanics (Distillation, Membrane Separation,...)

Combustion/Engine Development

Chemical Processes
Report Numbers

$22,28,34$

21,28

$14,16,19,20,21$

23

$3,21,33,38$

8 


\begin{tabular}{|c|c|c|}
\hline Information Type & $\begin{array}{l}\text { Comp lete ly } \\
\text { Included } \\
\end{array}$ & $\begin{array}{l}\text { Partially } \\
\text { Included } \\
\end{array}$ \\
\hline Reviews end-use consumption data & 17 & 1 \\
\hline $\begin{array}{l}\text { Estimates conservation potential } \\
\text { of technologies }\end{array}$ & 12 & 4 \\
\hline $\begin{array}{l}\text { Estimates technologies' time to } \\
\text { commercialization }\end{array}$ & 7 & 7 \\
\hline Summarizes existing research programs & 10 & 2 \\
\hline $\begin{array}{l}\text { Gives a methodology for ident ifying } \\
\text { research opportun it ies }\end{array}$ & 10 & 3 \\
\hline
\end{tabular}

Briefly, of the 38 reports, 18 presented some type of energy end-use data. In general, the reports that focused on particular energy-use functions gave enduse consumption data, whereas those that concentrated on generic research areas did not. Sixteen of the 38 studies made some effort to est imate the conservation potential of the technologies under consideration. Seven studies estimated the time to commercialization of the technologies, while another seven estimated the length of research required for particular tasks. Estimating research times is a less sophisticated form of analys is than estimating times to commercialization and was therefore marked as "partially" providing the required information in the fifth column of Table 2.1. Twelve of the 38 studies gave some form of summary of existing research programs relating to the research ideas identified.

Finally, on ly 13 studies used some form of systematic methodology for identifying research opportunities. The other 25 studies merely presented unjustified "laundry lists" of energy conservation research opportunities. The studies that did make use of a methodology generaliy used one of two basic approaches. First, some studies surveyed various experts in the field to solic it research ideas. While this method may produce reasonable results, the justification of the ideas is left up to the reader, unless detailed descriptions are provided with the ideas.

In the second method used to identify research opportunities, end-use energy data were reviewed for areas of large consumption and 1oss. Research ideas were then proposed to address these areas. This method is used by the 
American Institute of Physics (report No. 4), Grey (report No. 26), and Ross and Williams (report No. 36). Because this method directs the search for research opportunities toward areas where significant energy savings are possible, it produces ideas that have clear application to energy conservation. For this reason, the PNL assessment staff feels that this method is the more promising approach to identifying energy conservation research opportunities and deserves further analytical attention.

The PNL assessment staff's view of this sample of research opportunities studies has led to three general conclusions. First, the staffs feel that at this time research opportunities identification is more of an art than a science. However, the beginnings of systematic approaches are apparent in some of the above-mentioned studies. Given continued development of this approach, research opportunities identification could be made into a more systematic and rigorous activity than in previous work.

Second, the studies that focused on fairly narrow segments of the end-use sectors generally were able to produce more detailed, well-justified research ideas than were the broad, sweeping studies of the entire energy picture. For this reason, the staff feels that a single, all-encompassing analys is is not the proper approach to produce a detailed, comprehensive study of energy conservation research opportunities. Rather, a synthes is of the many small, detailed studies should be performed, using additional analyses only to fill in the gaps. Tables 2.2 and 2.3 are a first step in categorizing the various studies into consistent end-use and technical formats. Additional work is needed to further develop these formats, to locate the available studies and fit them into the structure, and to identify the areas where additional analyses are required.

A third conclusion drawn from these 38 sample studies is that a considerable difference exists between the studies that focused on end-use energy consumption and those that focused on generic research. The studies of generic research areas frequently failed to give the specific applications and conservation potential of their research ideas. An integrating effort is needed to 
collect these generic research ideas and to apply them to the energy conservation problems listed in the end-use oriented reports. Both the generic research and the end-use reports contain a wealth of ideas. A systematic compilation and integration of these ideas has been initiated here, and further work would significantly help to provide a prioritized agenda of research opportunities that would promote more efficient energy use. 


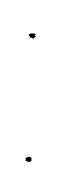




\subsection{ENERGY CONSERVATION RESEARCH OPPORTUNITIES}

The R\&D activities relating to energy conservation in the sample 38 studies are presented and discussed in this section. These activities, which were collected from the critical reviews, are categorized into the major energy end-use sectors: buildings and community systems, transportation, and industry. A generic category also is included for activities that cut across all end-use sectors but were not suggested as specific to any single sector. The classification includes a second level that indicates the general application or industry under which the R\&D need falls. In buildings and community systems, broad applications such as space conditioning and water heating are used. In transportation the general application is the mode of transport, such as auto and truck or aircraft. The categories in industry are divided among the various Standard Industrial Code (SIC) classes, although precise SIC classifications are not provided. The transportation and industrial areas are further divided into more specific processes and devices. Note that the classification levels below each end-use sector heading were chosen as the most conven ient for the available data. As the data base expands and the classification technique matures, these categories most likely will adjust.

The R\&D activities in each end-use sector are briefly discussed through a comparison of the following characteristics:

- short-term vs. long-term projects

- evolutionary vs. revolutionary ideas

- generic vs. process-specific activities

- technology base research vs. hardware deve lopment.

The first comparison, short-term vs. long-term projects, indicates the time horizon of both the suggested activity and in many cases the original reference. For example, several reports sponsored by the DOE were directed toward near-term needs in various industries. This comparison is also an indication of the potential role for technological developments in promoting energy efficiency. That is, long-term opportunities are unlikely to be abundant in sectors or processes that are not technologically sophisticated.

Evolutionary R\&D projects represent increases in the thermal or mechanical efficiency of current processes or devices, whereas revolutionary activities 
represent dramatic changes in current practices. The comparison indicates the potential for radically different technological options to achieve a given task. Radically different options are typically high-risk ventures that often offer a significant potential for energy savings. The comparison also indicates that some forms of nontechnical entrenchment occur for certain modes of a technology in an end-use sector. Several suggested R\&D opportunities may fall largely within an established mode of delivering a service, which is deeply rooted for institutional or other nontechnical reasons, while much less effort is placed on exploring alternate modes of providing the service. An example would be the substitution of communications for travel.

Generic activities, as previously defined, apply to more than one end-use sector, whereas process-specific technologies are generally applicable to a particular process. Levels of process-specific technologies indicate the degree of technological specificity of energy uses in a given sector. Conversely, levels of generic activities in the sectors point to degrees of crosscutting that might be achieved with various technology areas that share the need for common advancements and identify relevant process-spec if ic applications.

Finally, a comparison of work or iented toward technology base research vs. hardware development indicates whether the sector can benefit more from specific component development or from a broader fundamental base of development. This comparison also reflects a sector's technology intensiveness since a low technology area such as buildings and community systems does not seem to benefit from fundamental research as do the higher technology transportation and industrial sectors.

\section{GENERIC ENERGY CONSERVATION R\&D OPPORTUNITIES}

As mentioned several times, the generic category comprises activities that apply to more than one end-use sector and that were not specific to any particular end use in the reports. Generic opportunities are listed in Table A.1 in Appendix $A$. These activities are significant because of their broad potential application. Generic activities that may be applied to all three end-use sectors include research into heat exchangers, controls and sensors, alternate 
fuels combustion, tribology, high-temperature and corrosion resistant materials, and electric energy storage. Because of the diversity of R\&D opportu$n$ ities, these activities encompass the range of short-term to long-term research. As expected from generic projects, these advancements are also predominately characterized by evolutionary changes. Both generic hardware development and generic technology base research are represented in the list of activities. These categories interact with technology base projects, which include high-temperature, corrosion-resistant materials and which provide support for hardware development such as improved heat exchangers.

To illustrate the breadth of specific applications that may benefit from the development of certa in technologies, four areas have been selected: heat exchangers, heat pumps, sensors and controls, and alternate fuels and feedstocks. The R\&D examples have been se lected from Tables A. 3 through A.5 of Appendix $A$ and are intended to underscore the potential for specific and applied uses of generic developments. Table A.2 in Appendix A contains a list of the R\&D opportunities suggested in these four areas and the end uses to which they apply. Because Table A.2 is not intended to be comprehensive, the breadth of the information shown is more significant than specific items that might be missing. None of the R\&D opportunities listed in Table A.1 have been included in Table A.2 because the applications appropriate for the technologies in Table A.1 were not specified in the original reports. All four areas were mentioned in at least seven of the ten end-use focuses listed in Table 2.2. The controls and sensors area was most frequently included, having been mentioned in nine of the ten end-use areas.

Table A.2 also illustrates the wide variation in the detail of the R\&D opportunities suggested in the 38 reports reviewed. Some of the applied needs have very general descriptions of the technology and its application (e.g., heat pumps in the chemicals industry), whereas other descriptions are specific in delineating the application (e.g., air-to-air heat exchangers for ventilation in buildings). These two categories apply to most of the R\&D opportunities listed. A few R\&D suggestions offered are specific in describing the technological opportunity (e.g., ultrasonic methods of hot iron surface inspection); however, such detail was uncommon. 
Aga in, note that Table A.2 is not intended as a list solely composed of promising energy conservation R\&D opportunities. Some needs, such as the need for a heat pump to increase waste-water temperature from $100^{\circ} \mathrm{F}$ to $180^{\circ} \mathrm{F}$ for sanitizing and thawing in food processing, may already be largely realized, whereas others, such as the need for a heat pump to elevate $250^{\circ} \mathrm{F}$ waste heat to $400^{\circ} \mathrm{F}$ in cereal manufacturing, remain. Rather, Table A.2 illustrates the potential applications of crosscutting technologies through the example of heat exchangers, heat pumps, controls and sensors, and alternate fuels and feed stocks.

\section{BUILDINGS AND COMMUNITY SYSTEMS}

The buildings and community systems sector has the simplest taxonomic structure due to the limited variety of major energy uses. The primary end uses include space conditioning, water heating, lighting, appliances, and generic activities. The category of generic activities applies to R\&D suggestions that are generally appropriate to several end uses or that do not strictly apply to any of the previous categories. Table A.3 in Appendix A surmarizes from the literature review the research opportunities that address the buildings and community systems sector.

In building and community systems, space conditioning consumes the largest fraction of energy, 59\% in 1977, and appropriately comprises the largest number of identified R\&D activities relating to this sector. These activities include the areas of passive solar design and modeling, insulation, window technologies, infiltration, home instruments for monitoring and control, and active conditioning, which includes heat pumps, furnace efficiency improvements, and aircond itioner improvements.

The R\&D activities identified in these systems are predominately short-term efforts, mainly because building and community systems is not a technologically sophisticated sector. In many cases, such as passive design and modeling, the technologies exist but must be reapplied to meet new needs. The few long-term activities include developing advanced heat pumps, such as the Stirling and absorption cycle devices, and characterizing heat exchanger parameters. The demand ing conditions that challenge energy-use technology in both the transportation and industrial sectors are largely absent in buildings and community 
systems. Harsh environments with high-temperature, corrosive energy streams are uncharacteristic of this sector. Similarly, large energy loads, large fluctuations and the need for precise sensors and systems controls are uncommon.

Essentially all of the R\&D suggestions in these systems are evolutionary. No dramatic changes in building processes and design have been suggested. This situation again appears to have its roots in the low technology intensiveness of this sector and in the nontechnical barriers of radically altering the form of accepted building conventions.

Although most of the R\&D suggestions are device specific, a few can be applied to the industrial and transportation sectors. The relevant suggestions include the development of advanced heat pump cycles, heat exchangers, including better characterization of flow distribution and fouling, heat loss diagnostic equipment, and improved electric motors.

The R\&D activities in buildings and community systems also focus predominantly on hardware development as opposed to efforts that would establish a technology base. The exceptions are certain efforts in heat exchanger deve1opment and passive solar design research, such as the characterization of heat transfer at solid surfaces bounded by air.

\section{TRANSPORTATION}

R\&D opportunities identified in the transportation sector have been divided among the various transportation modes. From the studies reviewed, these categories are autos and trucks, aircraft, and generic activities. Generic areas include those that are common to several modes, such as alternate fuels and basic studies, and those activities that do not clearly fit into one of the defined modes, such as the substitution of communication for travel. Table A.4 of Appendix A presents the list of research opportunities that are collected from the individual reports and that address the transportation sector. Each mode is further divided into specific elements. In autos and trucks, which received the majority of attention in the reports surveyed, these elements include the engine/driver, aerodynamic design, transmission, tribology, materials, other losses, accessories, and advanced concepts. Because the auto and truck subsector dominates the R\&D activities presented here, it will be the focus of further discussion. 
The auto industry is unique in being a large, centralized and technologyintensive sector. In the U.S. the industry is composed of a few corporations that have the resources to support a significant leve 1 of R\&D. The R\&D suggestions obtained through the critical reviews span the breadth of short- to long-term projects. Short-term projects would include automatic control technology to better monitor and adjust the fuel mixture, timing and accessories and to reduce aerodynamic drag, which was cited in four of the ten reports dealing with the transportation sector. However, most of the suggested activities are weighted toward long-term projects, probably resulting from recognition of the industry's capacity to resolve short-term problems when necessary. Examples of long-term projects cited in the reports include the development of Stirling engines, ceramic materials, alternate fuels capability, reduced rolling resistance, and understanding the kinetics and mechanisms of combustion.

Although a clear bias exists toward long-term R\&D efforts, this bias is weighted toward evolutionary rather than revolutionary changes. The activities recommended are largely directed at improving the thermal, mechanical and aerodynamic efficiency of components through hardware development and basic studies. Similarly, the changes advocated in fuel type occur within the existing distribution system with an emphas is on those that are compatible with existing engine types. This evolutionary character seems to be due to a deeply established acceptance of the current modes of transportation support industries. The only revolutionary suggestion resulting from the reviews is the previously mentioned substitution of communications for travel.

The generic vs. process-specific nature of the R\&D activities is more balanced. Many of the advancements in engine development can be applied to both the industrial and buildings and cormunity systems sectors. For example, Stirling engine development would increase the efficiency and operating range of heat pumps. Tribological advancements, piston ring optimization and valve mechanization are other areas of generic engine application. Alternate fuels combustion and basic studies are also of generic value. These broad areas were identified with the understanding that the size and load differences between 
the transportation and other sectors would inhibit the direct application of new developments, but the similarities in needs will certainly enhance parallel development.

The transportation sector is also well represented by process-specific R\&D activities such as improved transmissions, reduced aerodynamic drag, and reduced rolling resistance. These types of activities, unique to uses in transportation, are directed at reduced losses by focusing on the primary contributors of loss: drag, weight, and engine inefficiencies.

Comparing efforts that aid in developing a technology base with efforts that aid hardware development also appears to result in an even balance. Basic studies in the areas of combustion processes, fluid mechanics, the modeling of unregulated and hydrocarbon emissions, and tribological studies can assist the design process through modeling, thus preventing traditional practices of individual design iteration. Hardware development received equal emphas is on the list of R\&D activities and cut across both generic and process-specific activities. Identified needs include the development of flywhee ls for regenerative braking, the continuously variable transmission, ceramic components, and the improvement of 0tto, diesel and stratified charge engines, as well as the development of Stirling and Brayton cycle engines. These two aspects, hardware development and technology base research, complement each other. Hardware development benefits from information provided by technology base research, especially in transportation where the relatively narrow focus of technologies facilitates interaction between these two classes of work.

\section{INDUSTRY}

Because industry is both the most diverse and most technology intensive enduse sector, a wide spectrum of R\&D opportunities exists. Industrial R\&D opportunities from the literature review are summarized in Table A.5 in Appendix A. The list of activities is rich in both short-term and long-term suggestions. However, the literature reviewed tended to lean toward short-term projects, largely because of a sponsor bias toward the shorter time frame. For example, in several DOE studies investigators were directed to focus on options that could be implemented by 1985. Even though the thorough evaluations in these reports focused on short-term activities, the studies were still useful in identifying possible long-term projects. 
The R\&D activities in this sector are also well represented by both generic and process-specific activities. Generic activities are considered to be both those cutting across several industries and those applicable to the other end-use sectors. Generic retrofits tend to focus upon improvements that do not change the flow of current processes. Examples of generic retrofits include high-temperature recuperators for recovering the exhaust from iron blast furnaces and glass furnaces, heat pumps and vapor recompression for drying processes, and high-temperature, corrosion-resistant sensing technologies for improved monitoring and control over processes in steel, glass, and ceramic furnaces. Generic activities are therefore evolutionary. The truly revolutionary processes are suspected to arise from process-specific developments. Through this mode, intermediate process steps can be eliminated, thereby improving both energy consumption and productivity. Examples include direct one-step steelmaking, direct casting of steel and strip, ore-to-powder systems, advanced food sterilization systems, and catalysts to modify chemical processes. However, the bulk of process-specific technologies presented in the reports tended to be evolutionary or incremental improvements over current methods. This bias aga in relates back to the time focus of the reports and is not a result of the relative merits of either improvements.

Similarly, a bias toward hardware development vs. technology base activities is evident in the list of R\&D activities and again appears to be a result of the time focus. Examples include the mach nozzle dryer in textiles and paper and pulp; microwave drying in food processing, grain, and paper; and pulp, heat pumps and high-and low-temperature heat exchangers in virtually all industries. Technology base ideas generally arise from documents that approach the topic from a fundamental perspective such as the ESCOE reports (Report Nos. 22 and 23) on fluid and thermal processes and advanced industrial processes and the Wolfe report (Report No. 4) on the efficient use of energy.

\section{SUMMARY AND CONCLUSIONS}

Because the purpose of this effort primarily was to provide information that would meet the needs of a companion report, An Overview of Energy Conservation Research Opportunities, the lists of R\&D opportunities in this study are not intended to be comprehensive. Rather, this report provides a 
broad catalog of previously published research ideas that could promote energy conservation. Additional work is needed to more systematically appraise available R\&D opportunities reports and to evaluate specific research ideas.

Reviews of the R\&D opportunities listed in the tables clearly indicated that certain activities that were applied to a specific process may also be applied to others equally as well. For example, in the chemicals industry one suggested opportunity is the use of alternate sources of feedstocks to replace natural gas and coal in ammonia plants. This opportunity most likely can extend to other chemical industries; however, further investigation would be necessary to identify the full breath of such potential.

Among the reports reviewed, the transportation and buildings and community systems were we 11 represented. The industrial sector was more difficult to thoroughly review because of the variety of diverse energy-using applications. The chemicals, textiles, and stone, clay and glass industries were least well covered, with only one report reviewed from each industry. The paper and pulp industry could also benefit from further coverage since only two reports were reviewed in that area. The primary metals, food processing and agriculture industries were better represented, with three reports reviewed in each.

In sumary, the greatest diversity of R\&D opportunities clearly appears in the industrial end-use sector. The transportation sector is technology intensive but far less diverse than the industries sector, and buildings and community systems offers the smallest variety of energy conservation R\&D opportunities. Generally, in these studies buildings and community systems tended to lean towards short-term projects, transportation to lean towards long-term projects and industry to mix both, but with slight emphasis towards short-term projects. The buildings and community systems and transportation sectors are generally characterized by evolutionary elements, whereas the industry is a mix of both evolutionary and revolutionary ideas. Additionally, although the buildings and community systems sector focuses slightly on specific devices, all three sectors are we 11 represented in process-specific and generic technologies. Further, technology base research is sparse in buildings and community systems, reflecting the sector's low technology intensiveness. All three sectors are well represented in hardware development opportunities. 
Finally, it is interesting to note that none of the studies reviewed thoroughly appraised advanced basic materials processes, such as the direct casting of stee 1 in industry. These processes may offer very significant energy savings and may therefore warrant further investigation. 
APPENDIX A

TABLES OF ENERGY CONSERVATION R\&D OPPORTUNITIES 


\section{APPENDIX A}

\section{TABLES OF ENERGY CONSERVATION R\&D OPPORTUNITIES}

The tables in this appendix present a categorized listing of the energy conservation $R \& D$ opportunities collected from the critical reviews included in Appendix B. Table A.l lists generic R\&D opportunities that weren't applied to specific end uses. To illustrate the specific end-use potential more clearly, applied R\&D opportunities for four example technologies are listed in Table A.2. These opportunities were extracted from the end-use-oriented opportunities listed in Tables A.3, A.4, and A.5. These last three tables show the R\&D opportunities according to the three major end-use sectors, buildings and community systems, transportation, and industry. The opportunities in the tables are further arranged according to narrower energy-use categories. 
TABLE A.1: GENERIC ENERGY CONSERVATION R\&D OPPORTUNITIES

R\&D Activity

Original Reference

Materials

(Report No.)

Tribology

Investigation of two phase bearings 27

Continued investigation of lubrication 27

Continued investigation of wear $\quad 27$

Water lubricated bearings for utilities 34

High temperature Babbitt-like materials 34

Characterization of long term stability of materials 28

in high temperature, harsh environments

Properties of wear resistant materials, especially 28 at high temperatures

Analys is and development of cylindrical roller bearings 34

for 3.0 million DN operation tapered roller bearings for 3.5 million DN

Mechan ism of fore ign particle wear 34

Refrigerant lubricated bearings 34

Foil bearing materials 34

Bearings for oxygen compressor service 34

Cage design and lubrication for small high speed 34 ball bearings

Series hybrid bearing 34

Development of rolling element bearing materials 34 having high fracture toughness

Gaspath seals active control of labyrinth seal 34 concentricity

Correlate microstructures and materials properties 28 with friction and wear behavior

Characterize the time-temperature effects on hard 28 surfacing materials

Standardization of wear testing methods and materials 28

Existing and future data need organization to be of 28 maximum design use

Wear control handbook 34

Documentation of energy-tribology statistics 34

Establish a list of reference properties for wear 28 technology related materials

Support of a national tribology testing 28

Establishment of a tribology information center 28

Advisory board 34

Applications workshop 34

Processing

Assessment of alternate processes 21

New and improved processes 21

Modification of material properties to reduced energy 12 intensiveness of materials 
Gener ic

R\&D Activity

Original Reference

Materials (cont'd)

Turbomach inery

Active control of blade tip clearance

Abradable blade tips and shrouds

Recycling

Materials from urban wastes

Energy from urban wastes

Energy and resources from agricultural wastes

Materials from combustion and conversion wastes

Energy and materials from waste-water sludges

21

Energy and materials from industrial waste

High Temperature

Investigation of materials properties at high

5,12 temperatures

Mechanics

Research on product failure, mechanism and fracture mechanics

Solar

Continued studies of the semiconductor physics of photovoltaic cells

\section{Genera 1}

Improve the data base on energy use in the materials 21 cycle

Materials property assessment for emerging energy 21 technologies

Ceramic materials assessment

Development of substitute materials

Systems study of the materials cycle

Integrated studies to support policy implementation

Heat Transfer

Enhancement

Understand the effect of finned tubes with shroud shapes 16

Investigate variable fin density 
Gener ic

$\underline{R} \& D$ Activity

Original Reference

(Report No.)

Heat Transfer (cont'd)

Enhancement (cont'd)

Understand the influence of tube row spacing, fin 16 height, and up stream turbulence

Vibration to increase gas side heat transfer coefficients 7

Boundary layer thinning techniques to achieve higher $\quad 7$

gas convective heat transfer coefficients

Study of heat transfer at interfaces

- role of convection and surfaces irregularities and surfaces irregularities

Surface roughness to achieve higher gas convective coefficients

- research is needed to improve our understanding of 7 the basic phenomena involved in high flux heat transfer and prevention of burn-out

- knowledge of how materials perform in high heat flux systems must be developed; improved materials may be needed

Degradation

Corrosion

Understand the fouling of augmented surfaces

$6,13,27,30$

Fundamentals

Flows around tubes and baffles

Multidimensional modeling of turbulent flows, including

a general stability condition

Transient phase geometry determination

Nonconventional

Focusing of heat transfer to achieve selective transfer, 7 through the use of electrostatic or magnetic fields

Electrostatic fields to increase gas side heat transfer 7 for coefficients

Investigate thermoe lectric elements $\quad 16$

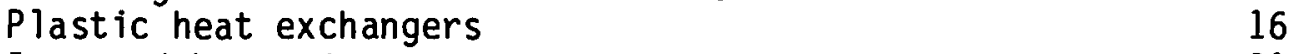

Improved heat pipes 31

General

Single phase heat exchanger improvements $\quad 13$

$\begin{array}{ll}H i g h \text { effectiveness } & 13\end{array}$

$0 i 1$ coolers 
Gener ic

R\&D Activity

Original Reference

Energy Conversion

(Report No.)

Combustion

A better fundamental understanding of the effects of turbulence on combustion, especially solid fuels, flame shaping, effects of combustion variables on flame heat transfer, and on pollution

Development of furnace design methodology, especially with regard to heat transfer, to make furnace design more of a science than an art and to reduce dependence on empirical design of limited applicability

Improved fluid bed combustors

Reactions of nitrogen and sulfur species in fluidized bed combustion

Develop scaling methods for fluid bed coal combustors and kinetics of coal combustion at high pressures

Localized temperature fluctuations in fluidized bed combustion and gasifiers as related to ash and agg lomeration

Particular or droplet behavior in liquid slurries and gas/vapor carriers

Hydrogen/hydrocarbon reactions in slurry reactors

Solid/hydrocarbon interactions in fluidized bed pyrolys is

Reactions and transport processes and solid state transformations in limestone particles under combustion, gasification and coal pyrolys is conditions

Relative rates of thermal catalytic reactions in hydrogenation catalysts particles

Mechanics and chemistry of char consumption and the interaction with ash under both combustion and gasification conditions

Lean combustion problems

Investigative problem of hydrocarbon destruction in the freeboard space of fluidized bed combustion

Combustion characteristics

- mixtures over an extended fuel-air range

- stability

- heat transfer from combustion products

Improved methods for scrubbing combustion gas

5,12

5,12

5,12

12,27

Alternate Fuels

Improved combustion of marginal fuels

Determine combustion characteristics

Coal utilization for energy and raw materials

$5, \frac{12}{12}$ 
Generic

R\&D Activity

Original Reference

Energy Conversion (con'd)

(Report No.)

Alternate Fuels (cont'd)

Coal fired gas turbine 37

Coal fired Stirling or Ericsson engines 37

Coal fired diesel engines 37

Motors

High efficiency electric motors

- alternating current synthesizer 36

Heat Pumps

Modeling 13

Seasonal operation 13

Furnaces

Heat exchange design and controls 13

Draft control 13

Cogeneration

Cogeneration of heat and electricity

- alternate engines (Stirling, closed cycle Brayton) 12

Gas Turbines

High temperature materials 13

Advanced turbine and compressor configurations 13

5-25 MW size for pumping and integrated energy systems 5

Coal fired gas turbines 37

25-100 MWe highly efficient, heavy fuel tolerant 5

gas turbines for cogeneration

Fuel Cells

Advanced fuel cells including molten carbonate fuel cell 5

Processes that produce chemical fuel from waste energy

7

which is, in time, used in a fuel cell to produce

electricity during peak periods

Higher reliability

Fuel flexibility

5

Lower costs

5 
Gener ic

$\underline{R \& D \text { Activity }}$

Original Reference

Energy Conversion (cont'd)

(Report No.)

Electrodes

Electrode reaction mechanisms including gas nucleation and evolution dissolution and precipitation reactions and solid transformation

Transport phenomena such as ionic transport in membranes and solid electrolytes and heat and mass transfer in porous electrodes

Understanding and improvement of electrode catalyses with emphasis on aging processes in oxygen, hydrogen and chlor ine electrodes, and electrocatalys is

Advanced

Themion ic converters

Lysholm helical screw expander

High temperature power cycles--up to $2500^{\circ} \mathrm{C}$

Fluid Mechanics

Separations

Investigation of osmosis

Basic research on transport in membranes

Investigation of absorption

4,27

Improved understanding of thin $\mathrm{f} i \mathrm{~lm}$ mechan isms

- establishment, maintenance, boiling

Hydraulics

Hydraulic transmissions

Mechanisms of turbulence and inertia in hydrodynamic bearings

Reduction of power loss in turbulent bearings

Fundamenta ls

Fundamental investigation of two-phase flow

Basic studies of boiling-aging effect

$16, \quad 27$

Turbomach inery

High speed pumps/turbines

- centrifugal separation effect

- theory and data for rotating flows

- steady and unsteady flow behaviors

- improved understanding of cavitation on phenomena 7 7 
Gener ic

R\&D Activity

Original Reference

Controls

(Report No.)

Sensors

Research on non-destructive testing

Quantitative NDE for energy conservation transmission and production systems

Self powered sensors for remote monitoring

22

Real time process control for manufacturing operations 22

Automated inspection systems for remote or hazardous 22 environments

Sensors for we 11 logging and minerals exploration 22

Automatic

Automatic monitoring of energy performance

Improved automatic control technology

$12, \begin{array}{r}12 \\ 27\end{array}$

General

Improved methods for energy monitoring and housekeeping

Storage

Therma 1

Thermal energy storage by freezing and melting 7 of high freezing point materials

Endothermic chemical storage, exothermic

Electric

Novel batteries

Rechargeable batteries of greater power density

Genera 1

Process

Process retrofit technologies

Advance physical understanding and mathematical modeling techniques

Analys is of energy required for various materials and processes to produce a specific part 
Gener ic

R\&D Activity

Original Reference

General (cont'd)

(Report No.)

Process (cont'd)

Basic new processes that reduce overall requirements

for energy and other resources per unit output

(e.g., recycling, durability)

Methods to assess and reduce net energy content of manufactured parts (i.e., starting with new net shape forms in machining processes)

Design

Greater incorporation of computer aided design,

computational methods, and optimization techniques

Incorporating life cycle energy accounting
Data bank and advanced design methodology handbook

Oxygen

Develop low energy, inexpensive method of producing crude oxygen or enriched air (e.g., absorption, diffusion, or para-magnetic separation)

A. 10 
R\&D Activity

Original Reference

Heat Exchangers

(Report No.)

Buildings and Community Systems

Air-to-a ir heat exchangers for ventilation

Heat exchangers to recover both latent and sensibie

27,37 heat

Improved heat exchangers for fuel-fired equipment

Basic heat transfer studies at solid-fluid interfaces, with a view to decreasing the temperature across heat exchangers operating close to ambient temperature

Applied toward improving air conditioners/refrigerators

- augmented surfaces to yield enhanced performance under dehumidifying, frosting or icing conditions

- contact resistance in the use of augmented fin surfaces must be reduced

- fouling factors

Chemicals Industry

Low cost heat exchangers

Exchanger coolant flow control

Primary Metals Industry

Heat exchanger development

High temperature heat exchangers and recuperators 25

Ceramic recuperators

Ceramic heat whee 1

Metallic counterflow recuperators 9

Flexible membrane development $\quad 19$

Fluid bed cooling 25

Textiles Industry

Heat recovery of contaminated exhausts 15

Heat recovery from boiler stack gas 15

Food Processing Industry

Improved heat recovery systems 17

Heat exchanger cleaning and filtering for fouling 17 prevention

Dryer exhaust recovery with fouling control 17 
R\&D Activity

Heat Exchangers (cont'd)

Stone, Clay, \& Glass Industry

More efficient heat exchangers to preheat raw materials using waste heat

Paper \& Pulp Industry

Improved low temperature heat exchangers

Application of fluid bed heat exchangers to waste heat recovery

Utilization of heat sinks or balancing condensors

ASME coding of compact heat exchangers

19

Improved paper mach ine hood economizers

Corrosion resistant economizers

19

Heat recovery from paper dryers using heat wheels

19

Reradiant recuperator

Agriculture

Utilization of lined tunnels below grade as heat 18 exchangers

Design equations for heat pipes \& heat exchangers 19

Heat Pumps

Buildings and Community Systems

Heat pump cycles and technoloty to extend the usefur 4 temperature range

Systems studies of solar-assisted heat pumps

Systems studies (and hydrology) of using ground water as the low temperature reservoir of a heat pump

Fuel fired heat pumps

Absorption heat pumps

Chemicals Industry

Industrial heat pumps

Textiles Industry

Heat pump utilization of waste heat streams

Food Processing Industry

Utilization of heat pumps in current manufacturing processes 
Food Process ing Industry (cont'd)

Heat pump for $200 \mathrm{~F}$ waste heat elevated to $450 \mathrm{~F}$ in 17 cereal manuf acturing

Waste water from $100 \mathrm{~F}$ to $180 \mathrm{~F}$ for sanitizing and 17

Stone, Clay, \& Glass Industry

Utilization of heat pumps

Paper \& Pulp Industry

Conserving hood waste heat $v$ ia heat pumps

Conserving waste heat in low temperature water to higher temperature water via heat pumps

Rankine and electric heat pumps

Agriculture

Evaluation of technical and economic feasibility of heat pumps for grain drying

\section{Controls \& Sensors}

Buildings and Community Systems

Development of an easy to use local heat flux meter

Development of infared equipment for diagnostic studies of houses

Development of cheap home instruments for monitoring and control

- degree-days-per-gallon meter (with suitable time 4 averaging)

- clock-programmed thermostat

- on-line monitor of furnace burner efficiency

Packaging of a meter to measure air exchange rate

The development for larger buildings of on-line monitoring of several features of air quality coupled with control of reconditioned air vs., fresh air

Advanced zoned temperature control (toward localized task heating

Controls for space heating and cooling

Basic studies of automat ic control technology

Meters for time-dependent utility pricing 
Controls \& Sensors (cont'd)

Transportation

Automatic control technology (fuel mixture, timing, $\quad 12$ and accessories)

Implementation of other monitoring meters of engine efficiency, fuel flow, and automatic transmission gear

Inexpensive miles-per-gallon meter

Idle-off systems

Primary Metals Industry

Computer optimization of power use in electric arc furnaces 9 High temperature inspection and surface conditioning 2, 9 Surface inspection

- ultrasonic methods

- eddy current methods

- optical and other methods

- hot grinding

Air-fuel ratio controllers

- multiburner combustors

Improvements in temperature sensing

High temperature sensors

Energy management through computer control

Computer control of blast furnace thermal \& metallurgical processes 
Paper \& Pulp Industry

Automatic control bleaching 35

Automatic control digester 35

Advanced a ir-fuel ratio control systems 35

Agriculture

Development of simplified flow meter

Alternate Fuels \& Feedstocks

Buildings and Community Systems

Water-oil emulsion for heating equipment

Transportation

Preparation and characterization of test fuels

Nove 1 fuels

Fuel emulsions

Hardware deve lopment testing

Development of auxilliary apparatus and instruments 33

Engine tests

Laboratory simulation tests

Data analys is and recommendations

Development of exhaust analys is techniques

Chemicals Industry

Biomass conversion to chemicals and polymers

Alternate sources of feedstocks for ammonia plants

11 to replace natural gas with coal

Coal liquefaction and gasification to provide chemical 11 feedstocks

Primary Metals Industry

Direct use of coal in manufacturing of oxide pellets 9 (replace oil or natural gas)

Biomass as fuel/reductant for iron ore

Hydrogen as fuel/reductant for iron ore

Stee lforming furnace using direct coal firing rather than $0 i l$ or natural gas

Heavy oil combustion

Pyrolys is of low grade coals

Cothane process for making methane from waste $\mathrm{CO}$ 
Alternate Fuels and Feedstocks (cont'd)

Textiles Industry

Alternate fuels for finishing

Ginning waste as a substitute fuel for drying

Generation of power for cotton gins by using gin waste

Food Processing Industry

Alternate fuels to replace natural gas

Utilization of solid wastes as an energy source

Methane production and anaerobic digestion of wastes

Paper \& Pulp Industry

Fundamentals of wood combustion (gasification, cogeneration applications)

Alternative fuels for lime $k i$ ins

Coal derived fuels for combined gas steam turbines

Bark and hog fuel preparation

Agriculture

Substitution of scarce fuels

Alternative source of energy - coal fired steam turbine

Alternative sources of energy for pumping energy

18

Feasibility of converting feedlot wastes to industrially useful oxychemicals

Integration of animal feeding, fuel production and fertilizer use in the use of crop residues and animal wastes

Define and demonstrate optimum systems for production of industrial chemicals from collected agricultural residues

Define and demonstrate optimum liquid fuel production production systems

Utilization of waste heat to enhance biogas production

Improvement of biogas production system reliability

Define and demonstrate gas-generating systems for farm and off-the-farm use

Define and demonstrate direct combustion of field crop residues for on-the-farm and off-the-farm use 
Table A.3: BUILDINGS AND COMMUNITY SYSTEMS CONSERVATION R\&D OPPORTUNITIES

$\underline{R \& D \text { Activity }}$

Original Reference

Space Conditioning

Passive solar design

- indirect and direct gain and thermal storage

Theoretical and experimental studies of external features, including sun control and surfaces of variable reflectivity

Microscopic studies, experimental and theoretical, (Report No.) moving air

Investigation of a "thermal diode"

$12,32,37$

Re-insulation methodologies

Movable window insulation

Improved insulating materials (flow phenomena in

porous media-pressure and temperature drop through insulation)

Development of layered material with variable, controllable conductivity

Optimization of insulation for the distribution of space heat

Environmental and health effects of insulation

Investigation of building materials with large spec if ic heats

Radon gas and other health impacts from building 27 materials

Development of window coatings to control heat loss 4 (low IR absorpitivity, photosensitive coatings....)

Inside: development of methods to control air flow, 4 especially near walls, windows, and ducts

Outside: studies of micrometeorology, wind effects 4 on heat transfer and infiltration, control of local air flow patterns

More flexible computer modeling to include the effect 4 of wind

Measurement and modeling of thermal response functions 4 of buildings (to changing weather conditions)

Theoretical modeling together with experimental studies to select new materials and filler gases, to control cell size, and to enhance fire resistance

Utilizing effluent waste energy in heating/cooling buildings

Systems analys is of district systems to supply both heat and electricity to a building house or group

Studies of heat transport over long distances (including heat transported as chemical potential energy)

Air-to-air heat exchangers (ventilation) 
Buildings and Community Systems

R\&D Activity

Original Reference

Space Conditioning ( cont'd)

(Report No.)

The development of devices to recondition air

Heat exchangers to recover both latent and sensible heat

Basic study of air infiltration

Search for new desiccants, especially with a view to

lowering the regeneration temperature

Heat pumps cycles and technology to extend the useful 4

temperature range

Systems studies of solar-assisted heat pumps 4

Systems studies (and hydrology) of using ground water 4

as the low temperature reservoir of a heat pump system
32

$\begin{array}{ll}\text { Advanced fuel-fired equipment } & 32 \\ \text { - fuel-fired heat pumps } & 32\end{array}$

- more efficient compressors 32

- multiple compressors (enhance part-load efficiency) 32

- improved heat exchangers 32

- more efficient motors 32

- automatic fan controls

- improved airflow 32

- absorption air conditioners 32

- absorption heat pumps 32

- gas turbine $\quad 32$

- Stirling engine 32

- diesel engine 32

- Rankine engines 32

Basic heat-transfer studies at solid-fluid interfaces, 4

with a view to decreasing $T$ across heat exchangers operating close to ambient temperature

Pilot/Burner retrofit

Electric pilot for gas furnace

12

Direct fossil-fired heating equipment

- reduce burner firing rate (by $25 \%$ )

- boiler water temperature reduction (35 F) 32

- burner efficiency adjustment 32

- retention head burner 32

- stack heat reclaimer 32

- low input/variable firing rate burners 32

- ducting combustion air from outdoors 32

- vent damper

- modern high efficiency burner-boiler

32,37

- blue flame burner-boiler

- outdoor boiler installation

32

- combustion a ir humidification

- water-oil emulsion 32 
R\&D Activity

Space Cond itioning ( cont 'd)

Advanced fuel-fired equipment

- pulse combustion furnaces and boilers

Development of easy-to-use local heat flux meter

Development of infared equipment for diagnostic studies of houses

Development of cheap home instruments for monitoring and control, such as a degree-days-per-gallon meter (with suitable time averaging)

Development of cheap home instruments for monitoring and control, such as a clock-programmed thermostat

Development of cheap home instruments for monitoring and control, such as an on-line monitor of furnace burner efficiency

Packaging of a meter to measure air exchange rate in a room 4 or building

The development for larger buildings of on-line monitoring of several features of air quality coupled with control of reconditioned air vs. fresh air

Advanced zoned temperature control (toward localized task heating)

Controls and distribution system

$$
\text { - controls for space heating and cooling }
$$

Solar space cooling

Systems studies of groundwater cooling

Interdisciplinary studies of ground-water hydrology for heat transfer applications

Broad search for new techniques using heat to power air conditioners; experimental studies of absorption nd absorption cycles

Improved air conditioners/refrigerators

- augmented surfaces to yield enhanced performance under dehumidifying, frosting, or icing conditions

- contact resistance in the use of augmented fin surfaces must be reduced

- study maldistribution of fluid

- fouling factors

- steady and unsteady flows in orifices, entrances, exits, branches

\section{Water Heating}

Continued development of solar hot water heating systems

Systems studies of heating or "boosting" water at the point of use

Detailed measurements and modeling of patterns of hot water heating and use in houses
Original Reference

(Report No.) 
Development of small and/or screw-in fluorescent lamps 4 (mostly engineering)

Basic research on gas discharges and on fluorescence with a view to increasing the efficacy of light sources and controlling the color

Development of efficient $\mathrm{kHz}$ power supplies and further studies of frequency-dependence of fluorescent-lamp efficacy

Exploration of more effective ways to use sunlight indoors

Interdisciplinary studies of lighting needs for various tasks - intensity, uniformity, spectral distribution

Appliances

Improved air conditioners/refrigerators

- augmented surfaces to yield enhanced performance under dehumidifying, frosting, or icing conditions

- contact resistance in the use of augmented fin surfaces must be reduced

- study of maldistribution of fluid

- fouling factors

- steady and steady flows in orifices, entrances 16

Integrated app liances

- air conditioner/water heater

- furnace/water heater

- refrigerator/water heater

- drain water heat recovery

High performance electric motors (appliances) 12

Gener ic

Systems studies of house-scale heat and electricity systems based on fuel cells (possibly ones deliberately chosen to have low electrical efficiency)

Solar: seasonal storage, cogeneration, heat pumps

Systems analys is of district systems to supply both

heat and electricity to a building house or group

Impact of waste heat utilization on power plant engineering Waste heat utilization for multicultural biological systems

Waste heat for desalination

Recreational use of waste heat

Energy transport and storage

Research on heat storage for better load averaging of both

solar and electric power 
Buildings and Community Systems

R\&D Activity

Original Reference

Generic (cont'd) (Report No.)

Basic studies of automatic control technology

Meters for time-dependent utility pricing

$\frac{12}{12}$

Controls and distribution systems

- controls for individual equipment (lights, etc.)

Extensive data gathering and modeling of energy-use patterns

4

of existing houses and buildings of various types

Inventory of energy sources and energy needs

19 

$\underline{R} \&$ D Activity

Original Reference

Autos and Trucks

(Report No.)

Engine/Driver

Improved Ot to cycle

Combustion efficiency and emissions research

Adiabatic diese 1

Reduction in size and weight of the diesel engine

Reduced no ise and emissions from the diesel engine

Gas floated pistons for adiabatic diesel

Lubrication system for adiabatic diesel

Coatings for extreme temperatures in an adiabatic diesel engine

Concepts and techniques for extreme high-temperature lubrication in an adiabatic diesel engine

Heater head design for the Stirling engine

Ceramic parts for the Stirling engine

General development of the stratified charge engine

General development of the Brayton engine

$4,26,31$

$4,26,31$

$4,26,31$

34

General development of the Rankine engine

Hybrid power plants (small internal combustion engines plus a source of boost power)

Electric vehicles

- high performance batteries

Aerodynamics

Reduced aerodynamic drag (experimental studies of autos and trucks, including effect of relative vehicle belly and road motion)

Transmission

Improved transmissions (continuously variable...)

Rheology of traction fluids

Traction fluid development

29,34

Concepts and designs of traction drives

34

Tractor CVT prototype development and testing

Thrust bearing for CVT

Materials for traction drives

Traction contact study

Tribo logy

Mechanics of boundary friction (sliding wear)

Piston ring - cylinder friction reduction 
Autos and Trucks

Tribology (cont'd)

Analytical model of $r$ ing lubrication

Piston ring optimization studies

Piston ring materials and coatings 34

Measurement of piston ring losses 34

Friction reduction

- xylan coatings

Coatings for extreme temperatures in an adiabatic 34 diese 1 engine

Concepts and techniques for extreme high-temperature 34 lubrication in an adiabatic diesel engine

Automotive engine lubricants

Improved understanding of non-Newtonian viscosity improvers

Improved understanding of relationships between viscosity, volatility, temperature and wear

Improved understanding and chemistry of interactions between lubricant add itives (compatibility and formulation techniques)

Materials

Reduced vehicle weight

- materials, crashworthiness of lighter vehicles

Ceramic materials assessment

Other losses

Reduced rolling resistance

- viscoelastic materials 31

- radial tire designs 31

- trade-offs between functions of wheels, tires and 31 suspension

Accessories

Automatic control technology (fuel mixture, timing, 12 accessories)

Implementation of other monitoring meters of engine 4 efficiency, fuel flow, automatic transmission gear

Inexpensive miles-per-gallon meter (real time data) 4

Idle-off systems 26

Valve resizing 26

Valve mechanization 3

Valve control assessment 3

Turbine design studies for compressive charging 3 
Autos and Trucks

Accessories (cont'd)

Supercharging assessment studies

Reduced accessory power

- heat powered air conditioners 31

Advanced working fluids 27

Advanced Concepts

Experimental and theoretical studies of flywheels 4

Harnessing braking energy with a dynameter 4

$\begin{array}{ll}\text { Chemical energy storage } & 12\end{array}$

Transportable heat engine van capable of delivering 31

steam and refrigerant to part-time food processing

plants during harvest

Aircraft

Materials

Lighter weight aircraft

- materials

12

- structural design

12

Aircraft engines with higher efficiencies and lower emissions

Gener ic

Alternate Fuels

Preparation and characterization of test fuels

Novel fuels

4,7

Fuel emuls ions

Hardware development testing

4,7

Development of auxilliary apparatus and instruments

33

Engine tests

Laboratory simulation tests

Data analys is and recommendations

Development of exhaust analys is techniques

Basic Studies

Theoretical and analytical studies

Spray combustion studies 


\section{Transportation}

R\&D Activity

Original Reference

Gener ic (cont 'd) (Report No.)

Basic Studies (cont'd)

Spray formation studies

Fuel injection dynamics studies

Engine modification design and evaluation

Modeling of unregulated $\mathrm{HC}$ emissions

Chemical kinetics and mechanisms

- experimental studies of unregulated HC emissions chemistry

- oil decomposition modeling

- emissions vs. oil consumption, engine measurement

Fluid mechanics

- rationalization of engine fluid mechanics

Miscellaneous

Improved intermodel transfer technology

Improved traffic control methods

Nove 1 ideas

Communications substituted for travel

27,37 
TABLE A.5: INDUSTRIAL ENERGY CONSERVATION R\&D OPPORTUNITIES

\author{
Chemicals
}

R\&D Activity

Original Reference

Processing

(Report No.)

Fundamental research in catalys is

Specialized catalysts for solution processes

Polymer characterization in a fundamental sense

Process development for polymer product ion in SIC 2821 (plastics, materials, and resins)

Developing less energy intensive processes for synthet ic rubber prroduction. Rubber prroduction via slurry or bulk reaction could be significantly less energy intensive than solution processes currently used

Fundamental research in surface chemistry

Determination of fluid pphysical and thermodynamic properties

Investigation of advanced water desalination methods

Exploration of catalyzed solar photolys is of water

Solar evaporation of potash brines to concentrate and crystallize potash

Conservation of energy during production of phosphoric acid 17

Wet grinding of phosphate rock

Conserve energy in phosphate rock mining by extracting $\mathrm{P}_{2} \mathrm{O}_{5}$ directly from rock-clay matrix

Improve heat reecovery in existing ammonia plants

Combine the operations of an anhydrous ammonia plant and a stee 1 blast furnace

Conservation of electrical power in granulation plants

Conservation of energy in granulation plants

Efficient marketing and distribution of fertilizers and agricultural chemicals

Study total energy consumption of marketing sytems for 17 anhydrous ammonia versus $n$ itrogen solution

\title{
Sources
}

Biomass conversion to chemicals \& polymers

Alternate souurces of feedstocks for ammonia plants to replace natural gas with coal

Use of coal as a fuel for ammonia plants instead of natural gas

Coal liquefaction \& gasification to provide chemical feed stocks (1) 


\section{Chemicals}

$\underline{R Q D \text { Activity }}$

Original Reference

Heat Recovery

(Report No.)

Heat exchangers

Lower cost heat exchangers

20

Exhanger coolant flow control

Gener ic

Electrical power generation $\quad 20$

Bottoming cycles 20

$\begin{array}{ll}\text { Industrial heat pumps } & 19\end{array}$

$\begin{array}{ll}\text { Expander technology } & 19\end{array}$

Absorption refirgeration $\quad 20$

Low cost chilled water 19

Pipe tracing, monitoring and control 19

$\begin{array}{ll}\text { Study of insulation characteristics } & 19\end{array}$

Fundamental research on corrosion 11

High temperature preheated combustion air and burners 20

Studies of adsorption techniques for molecular seperation 4

Utilization of government owned \& operated high energy 11 radiation sources for chemical process research

\section{General}

Provide (through NBS) continuing charcterization of basic 11 physical 7 thermochemical data on materials of interest to chemical \& polymer industry

Handbook on waste heat recovery systems and applications 19

Study of possible modes for federal incentives regarding 19 energy conservation 
R\&D Activity

Original Reference

Iron \& Stee 1

(Report No.)

Ore Preparation

Improved particle reduction (low energy)

- pelletizing

Direct use of coal in the manufacture of oxide pellets (replace oil or gas)

Conversion from natural gas or fuel oil to coal in pelletizing plants

Tar-bonded green briquetts charged to BF

Improved sintering process (McDowe 11-Wellman)

Self-reducing agg lomerates (carbon-bearing) for BF

Prereduction during final stages of agglomeration

Optimized fuel mix for agglomeration

Substitution of semicoke or char for coke breeze for agg lomeration

Grinding of iron ore

- improvement in particle classification

Recovery of heat from flue gas in agglomerating plant

Cokemaking Form coke

2,9

Dry quenching of coke

$2,9,25$

Improved particle reduction

- cokemaking

Coal injection

Charging of preheated coal to ovens

Automatic thermal control of coke batteries

Thermal stabilization of coke

Thin-wall coke ovens

Reduced-temperature coking (semi-coke)

Partial (surface) coking (semi-coke)

Ironmaking

Electrolytic refining of iron

Decreased slag volume ( $r$ icher ore)

Direct elecrolytic reduction of iron oxides to pure iron

Nuclear-derived heat for reduction of iron ore

Alkaline carbonates as catalysts for reduction of iron ore

Biomass as fuel/reductant for iron ore

Hydrogen as reductant for iron ore

9,10 
Steel Casting

Direct casting of thin-gage steel sheet 9

Continuous rheocasting of steel strip 9

Continous casting of preforms like beam blanks 2

Solidification (form nearer to final product)

- studies of effects on properties and processing 11

- formation properties of surfaces 11 
R\&D Activity

Original Reference

Iron \& Steel

(Report No.)

Steel Casting (cont'd)

- basic properties of melts \& slurriesll

- effects of non-uniformities such as fluid-flow, heat transfer, fusion temperature, \& compositonal variations on processing and properties

- modification of limiting factors (thermal diffusity..) 11

Stee lmak ing

Preheating of scrap charges to steelmaking furnaces

Electric arc furnace scrap

9,25

Woolworth scrap preheater

CO collection from BOF for scrap preheating

Use of EAF top gas to preheat scrap

Increased use of direct reduced iron

Electric arc furnace

- Modeling

Electric arc furnace modification

Computer optimization of power use in EAF

Conversion of regular-power EAF's to high power

Direct steelmaking with nuclear energy

Plasma-arc stee lmaking

Increased use of BOF off gas (suppressed combustion)

Utilization of BOF off-gases other than for scrap

preheating

Stee lf orming

High-temperature inspection and surface conditioning

2,9

Surface inspection

- ultrasonic methods

- eddy current methods

- optical \& other methods

- hot grinding

Direct rolling of ingots and slabs

Heating furnace designs for increased efficiency

Induction heating of slabs, billets, and bars

High frequency induction

Electric resistance heating of billets

DC electric resistance heating of continuous

sheets

Pulse heating

Monobeam slab-reheating furnace

Vacuum furnace 
R\&D Activity

Original Reference

Iron \& Stee 1

(Report No.)

Stee lf orming (cont'd)

Basic research into heating steel (electrical

properties of steel, effect of heating rates \&

method of energy application on properties, methods of applying energy)

Evaporative cooling of skids in reheat furnaces

Hot working and heat treatment

Improved forge furnaces efficiencies

Improved slot forge furnaces

Projectile forming

Elec troforming

Plasma arc spray forming

Fluidized-bed heat treatment

Computerized annealing system for batch coil annealing

Nitrogen-based carburizing atmospheres

Direct firing for batch annealing (replace radiant)

Furnace using direct coal firing rather than gas or oil

Continuous casting slurries

Powder metal lurgy

Powder rolling

Steel sheet via powder metallurgy

Mechanism of metal rolling

Metal processing

Waste heat recovery in annealing

Novel Processes

Direct (continuous) ironmaking/steelmaking (ore to steel in one step)

Advanced alternatives to the blast furnace--direct stee lmak ing

- basic mechanisms of oxidation and reduction 11

- problem of containment (refractory)

"S" process; DR shaft over vertical shaft melter

Plasma arc stee lmaking and spray forming together

Advanced alternatives to the blast furnace--plasma arc

- generating and maintaining plasma flowsll

Advanced alternates to the blast furnace

- methods of applying energy, particularly electrical

Produce electric power during $0 x$-Red reaction, also to generate hydrogen as a reducing agent

Advanced alternatives to the blast furnace--nuclear stee lmaking

- material requirements (severe in nuclear steelmaking) 11

Nuclear-derived heat for reduction of iron ore

Steam coal or lignite based process

\section{A. 32}




\section{Primary Metals}

R\&D Activity

Original Reference

Iron \& Steel

(Report No.)

Recycling

Increased recycling of scrap

Recovery of metallic and carbon values

Impurities removal from scrap

Heat Recovery

Waste heat recovery

Heat exchanger development

2,9

High temperature heat exchangers and recuperators

Ceramic recuperators

Ceramic heat whee 1

Metallic counterflow recuperators

Low temperature heat recovery

Flexible membrane heat exchanger development

Fluid bed cooling

Gener ic

Improvements in burner design

New coal burner

Blue flame burner

Coal injection with plasma burner

High-temperature recuperator/burner/ducting

Air-fuel ratio controllers

- multiburner combustors

Enrichment of combustion air in oxygen content

(by means other than addition of elemental oxygen)

Improvements in control of combustion

Heavy fuel oil combustion

Pyrolys is of low grade coals

Cogeneration

Gasification of coal to produce fuel

2

Continuous gasification of coal

Blast gasifier

Cothane process for making methane from waste $\mathrm{CO}$

Improvements in high-temperature materials

2,9

Ceramic-fiber insulation

Coatings with high IR reflectance and high durability

Improvements in temperature sensing

High-temperature sensors

Energy management through computer modeling and control

Computer control of BF thermal and metallurgical processes

Vapor recompression of $125^{\circ} \mathrm{F}$ steam 
R\&D Activity

Original Reference

Iron \& Steel (cont'd)

(Report No.)

Genera 1

Regional energy management

Improvements in plant energy management

Source-sink location coordination

Increase yield of various iron and steel processes

0xygen use in lime kilns; fluid bed process

Bleedwater chemical treatment

Environmenta 1

Basic mechanisms of fume formation, fine particle technology, dust formation, gas cleaning mechanisms, slag processing, materials recovery

Foundary

Cupola modification to eliminate after-burners

Coal-fired rotary furnace for melting iron (replace oil)

9

Alloys

Codeposition of alloys

Aluminum

Processing

Direct reduction of aluminum 11

Inert anodes

11

Purification technology for recycling aluminum alloys 11

Replacement of petroleum coke $w /$ coke from coal in anodes 11

Recover energy from spent bauxite discharge

Gener ic

Recycling

Recover valuable minerals from waste products (mill

tailings, smelter dust \& slag, scrubber sludge, steel plant slag, thermal power plant ash, garbage) 
R\&D Activity

Original Reference

Generic (cont'd)

(Report No.)

Fluid Mechanics

Improved understanding of fluid flow through

static \& dynamic particle systems

Separation \& Mining

Improve separation of minerals by use of high-gradient,

high-field magnets

Methods to extract minerals or metals from seawater

Develop alternative processes for extracting copper, lead, zinc, and nickel from sulfide ores

Study of energy inefficiencies in ore beneficiation to approach more closely the min imum separative work

Find better ways of fracturing rock

Basic research in grinding (only about $5 \%$ efficient)

Chemistry \& Materials

Improve flotation \& flocculation processes by research on surface active agents

Augment understanding of the physics \& chemistry involved in mineral processing

Study of impurity element distribution between slag, metal, matte and gas phases

Develop a data bank on the physical and chemical properties of metals and their compounds

Electrolyte

Basic reseach on the physics of charge transfer at

electrolyte-e lectrode interfaces

Research into principles of solid electrolytes 
Grind ing

Roller mill for raw material grinding

$\mathrm{Kiln}$

New cement process which uses no pyro processing step - 1

oxygen enrichment of kiln combustion air

Develop small non-rotating furnaces to produce Portland 11 cement

Recycling

Use of slag or other pozzolonic additives to Portland cement

Study processes to produce high quality clinker from waste cement dust

Generic

High temperature filtration to use $800-900^{\circ} \mathrm{F}$ waste heat from cement plants to produce electricity

Develop coal gasification units so that ash, sulfur and alkalies are not added to clinker composition

Genera 1

Ability to predict fundamental properties of cement products - reduces the requirement for overdesign

Development of radically changed compound composition in cement (e.g., silicates and aluminates that form at lower temperatures)

Advanced energy storage and transport

Change in standards from composition to performance 1 standards - permits substitional materials in cements

Glass

Me lt ing/F in ing

Glass and steel furnace refractories research to improve vessel life and product quality Innovative glass melting process research, e.g., high energy concentration in a small area and with rapid transport of batch through the zone 
R\&D Activity

Original Reference

Glass (cont'd)

Heat recovery

Thermal audit of waste heat sources

Stack gas heat recovery

Generic

Oxygen-enriched combustion air

General

Alkali resistant glass applicable to reinforce concrete, (e.g., reactions of cement with other filler materials)

Ceramics

Forming

Coating of fine mineral particles, e.g., coating of

fluxing materials in aggregate materials of proper size distribution in order to develop better ceramic bodies at lower temperatures

Genera 1

Fundamental research on surfaces of ceramics

Foamed ceramic materials; high strength at low density. (Low with construction group)

Fundamental studies on the brittle nature of ceramic materials; success will permit use of high temperature stable materials for turbine applications yielding magnificantly higher efficiencies

Fundamental studies for increasing the fuel effectiveness in firing ceramic products; some processes are on ly 5-10\% efficient.

Gener ic

Furnaces

High temperature preheated combustion air and burners 
Generic (cont'd)

Heat Recovery

Heat exchangers

More efficient heat exchangers to preheat raw materials 11 using waste heat

Heat pumps

Grind ing

Fundamental research on grinding processes

Recycling

Fundamental research on fly ash

Utilization of waste materials, tailings, recycle, etc.,
a) fly ash
b) calcium sulfate
c) slags and scorias
d) substitution for asbestos or other materials where there are environmental problems

Cogeneration

Electrical power generation

Cogeneration

Sensors \& Controls

Reliable temperature measurement process diagnostics

Mode ling

Fundamental system analys is for net process energy consumption, e.g., conversion to electricity from gas or oil for glass melting

Development of algorithms models for use in real industrial processes

\section{Storage}

Heat storage, (high temperature regenerative process) encapsulation in stable refractory material of materials which will change phases 
R\&D Activity

Original Reference

Gener ic (cont' $d)$

Genera 1

Lower temperature processes 11

Understand fine particle processes and characterization 11 techniques

Prereaction of materials, thermal or chemical, prior to 11 processing

Selected phase equilibrium diagrams

High temperature phase composition studies, would lead to high temperature processing units

New plants follow markets, need for local material and process variations to fit optimal model; basics of reformulation are not well established and research is necessary 
$\underline{R \& D \text { Activity }}$

Original Reference

Wood Preparation

Bark separation from chips

Pulping

Pulp washing

Pulp pressing

Mechanical pulping

Automatic control digester

Reuse of low-value heat to heat chips

Hydropyrolys is

Chemical Recovery

Plasma technology

Electrochemical regeneration using reducing power of black liquor

New lime producing technology

B leaching

Automatic control bleaching

Chemistry of causticization

Papermaking

Dry forming

High consistency forming/cleaning

11,35

Electromagnetic displacement

11,35

Fluid displacement

11

Physical displacement

11

Paper pressing

11

Extended $n$ ip press

High temperature forming

11,35

Mach nozzle drying

Mechanical dewatering

35

11

Fluidized bed drying

Microwave drying

Fundamentals of fiber-solvent interaction

24,35

Fundamentals of fiber-fiber bonding

Waste \& Heat Recovery

Improved low temperature heat exchangers $\quad 19$

Low level heat utilizationll

Application of fluidized bed heat exchangers to waste heat recovery 
Utilization of heat sinks or balancing condensers $\quad 19$

Reduce water to recovery boiler

ASME coding of compact heat exchangers 19

Improved paper machine hood economizers 19

Corrosion resistant economizers $\quad 35$

Heat recovery from paper dryers using heat wheels 35

Reradiant recuperator $\quad 35$

Conserving hood waste heat via heat pumps 19

Converting waste heat in low temperature water to 19

higher temperature water $v$ ia heat pump

Investigation of feasibility of bark drying for $\quad 19$ heat recovery

Economics of solar augmentation and conceptual design 19

of system for waste stream heat recovery

New recovery technology

Resource recovery logistics 35

Wastepaper recycling $\quad 35$

Wastepaper characterization $\quad 35$

Solid waste (sludge) utilization 11

Batch-digester heat reuse $\quad 35$

Freeze crystallization of black liquor $\quad 35$

Bark and hog fuel preparation $\quad 35$

Generic

Use of hot water from flue gas scrubbing 35

Cogeneration $\quad 35$

Vapor compression $\quad 35$

Rankine and electric heat pump $\quad 35$

Automatic control recovery boiler $\quad 35$

Advanced air/fuel ratio control systems 35

Clean-burning bark burners $\quad 35$

Fundamentals of wood combustion (gasification, 11 cogeneration applications)

Alternative fuels for lime kilns $\quad 35$

Coal-derived fuels for combined gas steam turbines 35

Membrane technology for air enrichment $\quad 35$

Pressurized fluidized bed $\quad 35$

Gasifier $\quad 35$

Low cost gasifier 11

Steam distillation of methanol 35

General

Higher feedstock temperatures - allows for reduced 24 $v$ iscosity, surface tension, and increased drainage (reduces pumping losses); also means less heat would be needed in the drying section 


\section{Paper \& Pulp}

R\&D Activity

General (cont'd)
Original Reference

(Report No.)

Solid waste disposal

Non-biological effluent treatment

Improved pest control

11

Biological, genetic improvements in trees

Increased end product mo isture

35

Computer applications to energy management

35

Technical information

35

Energy management handbook 
Development and dissemination of technical educational materials and technology transfer

Development of alternatives to current package sealing techn iques

Integrated energy systems for dried food products

Identification and evaluations of constraints on energy utilized by the dairy products industry

Development of a $2: 1$ sterile concentrate milk beverage

Improvement of energy efficiency of in-plant clean-up practices

Phase I: Feasibility study of sterile fluid milk as a major conservation measure; Phase II: Development and demonstration of a pilot system

Fruits \& Vegetables

Improved refrigeration equipment and processes

Earth covered and/or underground storage of cold and/or

frozen products

Water removal

Sterilization

Bulk reduction to decrease handling, warehousing and transportation costs

Grain

Improved equipment design

Alternate processing and formulation methods to reduce energy consumption

Liquid concentration

Improved technology for process and moisture control

Re-use of hot and/or tempered water through filtration

Reduce energy used in high pressure and high temperature water beef carcass washer

Systems analysis of energy use in the meat industry

Recycle waste water effluents through reclamation system to produce crystal clear potable water certifiable by U.S. Health Dept. Laboratories

Reduce energy used in beef and hog viscera inspection tables Investigate use of outside winter air for refrigeration in northern plants 


\section{Food Processing}

R\&D Activity

Original Reference

(Report No.)

Meats (cont'd)

Substitution of sanitation for refrigeration energy to reduce 17 energy used in chilling red meats

Elimination of after-burners

Reduce natural gas consumption in hog singeing operation

Develop means of eliminating condensation on plant ceiling

that is less energy intensive than current procedure

Hot deboning

Industrial boiler system

Development of alternate methods for chilling carcasses

Develop alternate method of removing water from material to be rendered inedible

Improving scalding and de-hairing methods for hogs, on-line with mechanical equipment and chemicals

Vacuum chilling and storage of red meat

Reduction of the amount of water used in all meat and poultry processing plants

Immersion chilling of red meats

Microwave for processing - new construction

Pressurize meat processing smoke houses

Reduce energy use in refrigerated transport

Demonstration of energy conservation measures

Minimize packaging material for meats

Gener ic

Improved combustion efficiency

Automatic air/fuel ratio control for small boilers

Recovery of lost heat escaping plant in waste effluent

Better ammonia and freon refrigeration systems and controls for defrosting

Elimination of steam traps with introduction of a sump at

lower physical level and pumping of condensate under

pressure to steam generator

Improved steam traps

Improved heat transfer and heat recovery capability of

drying systems

Improved heat recovery systems

Heat recovery - gases and water

Refrigeration waste heat recovery

Raise low pressure steam to 100 psig level by compression 17 cycle

Vapor compression with wetter steam

Utilization of heat pumps in current manufacturing processes

Improve the efficiency of absobbers for $140 \mathrm{~F}$ input water Heat pymp or heat pipe for $250 \mathrm{~F}$ waste heat elevated to $400 \mathrm{~F}$ in cereal manufacturing 


\section{Food Processing}

$\underline{R \& D \text { Activity }}$

Original Reference

Generic (cont'd)

(Report No.)

Waste water $100^{\circ} \mathrm{F}$ to $180^{\circ} \mathrm{F}$ for sanitizing and thawing 17

Increase of water temperature for clean-up using solar 17 augmentation

Heat exchanger cleaning and filtering for fouling prevention 17

Dryer exhaust recovery with fouling control 17

Recovery of contaminated condensate for reuse 17

Electrical production during generation of low pressure steam 17

Fuel cell application 17

Reuse of hot or tempered water through filtration 17

Fuel substitution $\quad 17$

Alternate fuels to replace natural gas 17

Utilization of solid wastes as an energy source 17

$\begin{array}{ll}\text { Heat storage in small volumes } & 17\end{array}$

Methane production and anaerobic digestion of wastes 17

Genera 1

Pack aging

Equipment ratings

Systems studies of industrial parks

Evaluation of current practices in food processing firms

Education of the public

4-day, 40-hour work week effect on energy consumption, and effect on economies of various plant capacities 
Textiles

R\&D Activity

Original Reference

Preparation \& Dyeing

(Report No.)

Mo isture analyzer

$\mathrm{Pad} / \mathrm{batch}$ preparation and dyeing

15,19

Energy optimization in textile scouring

15

Energy efficient mo isture removal systems

15

Direct application of process chemicals

15

Low-energy continous dye systems

15

Sludge incineration

15

Anaerobic digestion of sludge

15

Wet process modification

15

Foam dyeing

19

19

Spray dyeing

19

Wet-on-wet dyeing

19

Vapor dyeing

Electrostatic deposition of dyes

Conversion from pneumatic to mechanical materials handling at gins

Reduction of energy consumption in wool scouring

Reduction of hot water usage in wet-processing of cottoncontaining textiles

Elimination of drying processes in wet-processing of cotton-containing textiles

Field cleaning of seed cotton

Improved lint cleaning at gins

Improvement of efficiency of gin seed cotton dryers 17

Fiber and raw material

- maximize use of raw materials

11

- separation, recovery, and resuse of fiber, chemicals

11

Yarn and Fabric

Tuft to yarn system

Low energy sizing

Electrostatic waste removal

Optimizing power needs of greige mill

Curriculum for fixers \& changers

Energy conservation in yarn forming and preparation

Electrostatic spinning

Computer model of energy needs of a mill

Energy conservation in texturing

Energy conservation in weaving

New fiber-to-yarn techniques for agricultural fibers

Fin ishing

Mo isture analyzer

Low temperature curing

15,19

Improvement of drying technology 


\section{Textiles}

R\&D Activity

Original Reference

Fin ishing (cont'd)

(Report No.)

Optimization of drying techniques 15

Metering techniques for finishing agents 15

New size development $\quad 15$

Development of effective mechanical dewatering techniques 11 to minimize energy required for drying (paper industry ana logy)

$\begin{array}{ll}\text { Study of the machnozzle } & 15\end{array}$

Radiation curing $\quad 15$

Systems analysis of a finishing plant $\quad 15$

New bleaching technology 15

Microwave or dielectric heating $\quad 15$

Modification of steam can technology 15

Flame curing finishes $\quad 15$

Mass and energy flows in a textile finishing plant 19

Tenter frame drying 19

$\begin{array}{ll}\text { Radiation curing } & 19\end{array}$

Spray finishing 19

Wet-on-wet finishing 19

Vapor finishing 19

Electrostatic deposition of finishes 19

Heat recovery

Heat recovery of contaminated exhausts $\quad 15$

Heat pump utilization of waste heat streams 19

$\begin{array}{ll}\text { Cleaning exhaust emissions for heat recovery } & 15\end{array}$

Heat recovery from boiler stack gas 19

Gener ic

Development of cogeneration systems $\quad 15$

Development of coal boiler 15

Exhaust gas incineration $\quad 15$

Power measurement equipment $\quad 15$

Energy conservation via lubricants $\quad 15$

Alternate fuels for finishing 15

Ginning waste as a substitute fuel for drying 17

Generation of power for cotton gins by using gin waste 17

Application of heat pumps to specific textile processes 19

Compression process using hydraulic power instead of steam 17 power

Development of pressurized hot water vs. steam for process 11 heating systems (includes reuse of hot process liquors) 
Textiles

R\&D Activity

Original Reference

Generic (cont'd)

(Report No.)

Development of improved insulation and heat storage technologies to minimize heat energy requirements

Development of automatic power factor correction techniques for individual electric motors

Control and correction of high-frequency transient peaks by Lener diodes

Development of more efficient electrical motors

Improved management and control of electrical energy demand

Improved synchronous switching of heavy electrical loads

Minimize air cooling and humidification requirements

Effluent neutralization via flue gases

Anaerobic digestion of concentrated waste

Projection of future solar collector costs

General

Improved screening and evaluation of developments and 11 innovations

Energy analysis of textile processes

State-of-the-art review of energy use in textiles 15

Dewatering processes

Improved process efficiency

Improved in-plant environment for process control and 11 workp lace

More efficient machines 11

Continuous product flow 11

Retrofits for improved efficiency 11

Process improvement

- new, more efficient routes from fiber to product

fiber to product

Low-energy processing

Reduce use of liquids

Compressed process lines

Continuous flow, improved materials handling

Product modification

Product improvement

- improved durabilty, useful life 11

- improved performance

- individualization of basic product through finishing 11 versus construction

Development of new end uses for textile and apparel 11 industry by-products

Development of new generic fibers from renewable resources 11

Development of new natural fibrous and auxiliary 
Textiles

R\&D Activity

Original Reference

Genera 1 (cont'd) (Report No.)

Optimization of fiber blends and fabric finishes for both function and ease of separation and recycling

Development of economic recycling techniques for extraction of fibrous materials from fin ished fabrics

Development of effective energy cost accounting by style, shade, etc.

More effective manpower training in energy-conservative skills (possible new incentives for conservation) 


\section{Agriculture}

$\underline{R \& D \text { Activity }}$

Original Reference

Crop Production

(Report No.)

Increased fertilizer efficiency 18

Biological nitrogen fixation 18

Energy reduction through increased pesticide efficiency 18

Energy conservation through reduced tillage 17,18

Reduced weather vulnerability 18

Cropping for more energy-efficient food chains 18

Multiple cropping for energy efficiency 18

Loss reduction in harvesting 18

Increase efficiency of nutrient utilization 18

Energy conservation through genetic improvement 18

(photosynthetic efficiency)

Effect of continuous crop residue removal on soil 18 productivity

Agricultural utilization of non-agricultural by-products 18

A systems approach to energy conservation in agricultural 18 production

Alternate portable fuel systems for agricultural production 18

Reduction of transport energy in crop production 18

Systems approach to utilizing waste heat in intensive crop 19 production and marketing

Animal Production

Improved milk-handling procedures $\quad 18$

The facts of meat animals and energy use 18

$\begin{array}{ll}\text { Potential for energy-flexible systems } & 18\end{array}$

Promotion, acceptance, and adoption of energy-saving methods 18 of livestock production

Develop and demonstrate forage and grain handling systems 18

Feasibility of the utilization of industrial low temperature 18 waste heat

Integrated milk production and sanitation systems 18

Future requirements for energy in an imal and poultry 18 production

Energy self-sufficient animal production systems 18

Minimizing energy costs of environmental modifications of 18 animal production systems

Improve motor efficiency and make more efficient use of 18 motors in farmstead equipment

Matching animal production with processing or manufacturing 18 process

Conservation of energy used to control the environment in 18

livestock housing

Conservation of energy in the construction and use of 18

buildings for livestock production 
Agriculture

R\&D Activity

Original Reference

(Report No.)

Animal Production (cont'd)

Development of effective animal manure management systems 18

Conservation of energy used for handling livestock waste 18

Recovery and development of energy from animal excreta 18

Energy conservation in feed-handling equipment 18

Improvement of the energetic efficiency of animals by 18

physiological and nutritional means

Conserving energy in transport

18

Environmental control of swine houses utilizing waste 19 heat contained in liquid streams

Environmental control of poultry houses utilizing waste $\quad 19$ heat contained in liquid streams

Development of intensive catfish finger ling production $\quad 19$ systems utilizing power plant discharge water

Intensive integrated fish production utilizing waste heat $\quad 19$

Other Production

Combination systems for aquacultural production 18

Domestic aquacultural production 18

Improving efficiencies of vehicle use in aquacultural 18 production

Utilizing low grade waste heat in aquacultural production 18

Increasing efficiency of materials - handling systems in 18 aquacultural production

Utilizing waste heat from steam electric-generating plants 19 in the culture of aquatic food

Combination systems

Establishing data base for energy conservation in controlledenvironment agriculture

Substitution of scarce fuels

Reduction of energy use in the transportation and marketing of vegetables, fruits, and flowers

Systems analys is of intensive vegetable, grain and flower 18 production for energy conservation

Biological and physiological alterations of crops 18

Development of new construction materials for greenhouses 18

Increased space utilization in greenhouses 18

$\begin{array}{ll}\text { Greenhouse orientation and shape } & 18\end{array}$

$\begin{array}{ll}\text { Improved greenhouse heating systems } & 18\end{array}$

Reducing energy consumption for cooling greenhouses 18

Reducing heat losses in greenhouses 18

Energy-effective use of lighting systems for heating and 18 constant year-round production

Utilizing power plant waste heat for greenhouse environmental 19 control 


\section{Agriculture}

R\&D Activity

Original Reference

(Report No.)

Other Production (cont'd)

Heating greenhouse crop-rooting media and enhancement of

greenhouse above root media atmosphere with $\mathrm{CO}_{2}$ from

relatively clean stack heating

Utilization of area waste heat by area agriculture

Crop variety testing in waste heat-warmed soil conditions

Economic feasibility of soil warming systems

19

Distribution for piping systems for soil warming and subsurface irrigation

Heat and mass transfer in soils as applied to soil warming

Enhanced water plant producton for food, feed, and biomass via waste heat

Large scale environmental control complexes

On Farm Processing

Use of industrial waste heat for crop drying

Identification of potential areas of using waste heat

for crop drying

Mechanisms for utilizing waste heat to dry agricultural crops

Preservatives to delay drying as applied to cereal grains

Development and demonstration of dryeration

18

Utilization of lined tunnels below grade as a heat exchanger

18

Direct oil-fired burner for crop drying

Evaluation of technical and economic feasibility of heat pumps for grain drying

Investigation of the technical and economic feasibility of a coal-fired grain dryer

Innovative design of grain dryers

Low temperature grain drying

Heat recovery systems for crop dryers

Grain dryer fuel from non-grain plant parts

Containerization for low-energy grain handling

Establishing energy use patterns for livestock feed processing/hand ling systems

Energy conserved and effect on electrical demands resulting 18 from peak load shifting

Demonstrating energy conservation through recycled heat from 18 dairy farm milk refrigeration units

On-farm milk volume reduction systems

Annual cycle energy systems applied to farm processing

Use of low grade energy contained in liquid effluents for dairy operations

Heat storage for agricultural uses

Methods for waste heat transport with distance limitations

Utilization of waste heat in closed-loop, dehydrationpelletizing systems 
Agriculture

R\&D Activity

Original Reference

Water Resources (cont'd)

(Report No.)

Recharge of aquifiers to reduce lift for pumped irrigation 18

Measures for retaining water on land to reduce irrigation 18 pumping

Development of a simplified flow meter 18

Drainage materials and design practices for energy conservation 18

Energy conservation by improved drainage pumping plant 18 efficiencies

Energy conservation in agricultural drainage installation $\quad 18$

$\begin{array}{ll}\text { Irrigation system efficiency } & 18\end{array}$

Improvements of motor and engine efficiencies 18

Energy conservation due to improved pumping plant efficiencies 18

$\begin{array}{ll}\text { Irrigation management } & 18\end{array}$

Energy limitations for reclamation of submerged lands 18

National impacts of energy conservation in water resources 18

Development of educational material for evaluating alternatives 18

to improve pumping plant efficiency

Water harvesting as an alternative to pumped irrigation 18

Water application efficiency 18

Development of new we 11 screens and gravel pack procedures 18

to reduce drawdown in wells

Use of waste water to replace pumped water 18

Crop response to limited water and nitrogen input 18

Solar energy as an alternate source of energy for pumping 18 water

$\begin{array}{ll}\text { Wind as a source of energy for pumping water } & 18\end{array}$

$\begin{array}{ll}\text { Improvement of pump efficiency } & 18\end{array}$

Alternate source of energy - coal fired steam turbine 18

Alternate sources of energy for pumping water 18

Gener ic

Waste heat utilization to improve quality of inland 19

water streams

Frost control via waste heat sources $\quad 19$

Advancement of refrigeration and air conditioning 19

$\begin{array}{ll}\text { technologies utilizing waste heat } & \\ & 19\end{array}$

Survey of waste heat recovery and utilization for 19

agricultural applications

Production of fresh water in arid regions using waste heat $\quad 19$

Design equations for heat pipes/heat exchangers 19

Substitution of scarce fuels 18

Methods for waste heat transport with distance limitations 19

Byproducts

Use of byproducts in agriculture

17

Feasibility of converting feedlot wastes to industrially 18 useful oxychemicals 
Agriculture

R\&D Activity

Original Reference

Byproducts (cont'd)

(Report No.)

$\begin{array}{ll}\text { Demonstration of cascade feeding systems for poultry, } & 18\end{array}$ steers, and brood cattle

Health and consumer aspects in the feeding of animal wastes 18 to livestock

Development of energy-efficient equipment to collect, process, 18 store and re-feed livestock wastes

Relative efficiency and economic aspects of utilizing manure 18

Use of mineral content derived from crop residues 18

Integration of animal feeding, fuel production and fertilizer 18 use in the use of crop residues and animal wastes

Demonstration of practical methods of $\mathrm{CO}_{2}$ enrichment for 18 crop growth

Increase developmental efforts on the enzymatic hydrolysis of 18 cellulosic residues to sugars

Define and demonstrate optimum systems for production of industrial chemicals from collected agricultural residues

Define and demonstrate optimum liquid fuel production systems 18

Utilization of waste heat to enhance biogas production 19

Improvement of biogas production system reliability 19

Define and demonstrate gas-generating systems for farm and 18 and off-the-farm use

Demonstration of direct combustion of field crop residues for 18 off-the-farm use

Demonstration of direct combustion of field crop residues for 18 on-the-farm use

Definition of economical methods of whole crop harvesting for 18 optimum grain quality, energy use, and residues collection

Practicality of the redesign of grain crops to maintain grain 18 yield but increase total biomass

Availability of field crop residues for specific crops and 18 regions

Development of methods for harvesting, storing and transporting 18 crop residues considering off-the-farm use

Use of waste heat to enhance composting 
APPENDIX B

CRITICAL REVIEWS 
APPENDIX B

CRITICAL REVIEWS

The first section ' format utilized by the assessment staff of this study to write the reviews of individual research opportunities studies. This outline is followed in each of the individual reviews included in this Appendix.

The second section of the Appendix presents the written reviews of the 38 reports that were surveyed for this study. The summaries in Tables 2.1, A.1, A.2, A.3, and $A .4$ are taken from these reviews. Each written review presents a sumary of the types of information provided in the report, a list of R\&D opportunities and a critical summary by the reviewer that follows the outline shown in section one. Many of the individual reviews also attach material from the reports, such as tables, figures, or bibliographies. These reviews and attachments provide a summary of the salient information on energy conservation research opportunities presented in the 38 reports reviewed for this study.

The third section of this Appendix presents a bibliography of 88 reports that discuss energy conservation research opportunities. The 38 reports that were reviewed for this study are included in this section and are indicated by a bullet ( $(\bullet)$. The additional 50 reports shown in this bibliography are those that we feel should be reviewed in any further efforts of this type. 

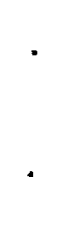

. 


\section{B.1 CRITICAL REVIEWS--FORMAT}

1. Standard Bibliographic Reference -including source of funding (sponsor)

11. Areas of Technical and/or End-Use Focus -describe at level of detail appropriate for report

III. Types of Information Provided (describe where necessary)

1. Did report review energy end-use data relating to focus of study?

2. Did report estimate energy savings that could result from research?

3. Did report est imate time to commercialization of technologies being considered?

4. Did report review existing research programs relating to technologies being considered?

5. Did report present a methodology for identifying research opportunities? (if so, describe briefly)

IV. List of Individual R\&D Opportunities

1. Description of Research Opportunity (as presented in report) -page in report that refers to R\&D opportunity -sector/device/process to which R\&D applies -technical barrier addressed

-why is this R\&D needed? (in end-use or technical terms)

2. Est imated Energy Savings from Use

3. Time to Commercialization

4. Existing R\&D Programs

5. References that Offer Additional Information

V. Critical Summary -comprehensiveness

- level of detail

-technical accuracy

-justification of R\&D opportunities

VI. Individual Reviewer's Comments -compatibility with other studies -any remarks not addressed elsewhere in review 
VII. Attachments -summary tables or figures that describe research opportunities -bibliographies of other research opportunities studies 
B.2: REV IEWS OF 38 INDIV IDUAL

ENERGY CONSERVATION R\&D

OPPORTUNITIES STUDIES 

- Report No. 1

I. A.D. Little, Inc. Environmental Considerations of Selected Energy Conserving Manufacturing Process Options. Volume $X$. Cement Industry Report. EPA-600/7-76-034j. U.S. Environmental Protection Agency, Cincinnati, Ohio. 1976.

II. Technical and/or End Use Focus

The report focuses on the calcining step which uses 70 to $80 \%$ of the energy used in cement production. Only process changes having a high probability of implementation by 1991 were studied in detail; this limited the study to four processes which exist today and are the product of a considerable number of years of active development. Four other processes are mentioned on page 4. The report assesses the four selected processes with respect to pollution and environmental consequences, probability of potential for change, and energy conservation consequences.

III. Types of Information Provided

1. Energy use data were reviewed for the cement industry (yearly) and the predominating cement production process (Btu/ton of cement) and for each of the four selected clinker processes (Btu/ton).

2. Energy savings from R\&D not estimated.

3. Time to commercialization not estimated.

4. Existing research in cement production not reviewed.

5. Selection of processes to be studied based on highest energy-using step and existing commercial processes.

IV. R\&D Opportunties

No R\&D opportunities were listed for the four focus calcining processes, presumably since they are already fully developed. There may be R\&D opportunities, not expressed in this report, for the four other energy conserving processes mentioned:

- roller mill for raw material grinding

- oxygen enrichment of kiln combustion air

- new cement process which uses no pyroprocessing step

- use of slag or other pozzolonic additives to Portland cement.

V. Critical Summary

Comprehensiveness, level of detail and technical accuracy for the process changes studied are very good. Apparently, there are no significant remaining R\&D opportunities in those four processes. R\&D opportunities identified have only to do with characterization of gaseous and particulate emissions and possible use of waste kiln dust (apparently not a big problem). 
VI. Comments

The four processes mentioned in III above should be reviewed for energy conservation potential and possible R\&D opportunities.

Reviewed by WEG. 
- Report No. 2

I. A.D. Litt le, Inc. RD\&D for Energy Conservation Preliminary Identification in Iron and Steelmaking. SAN/1692-1. Division of Industrial Energy Conservation, U.S. Department of Energy, January 1978.

II. Technical and/or End-Use Focus

This report focused on near-term (5-10 yr) research needs in the Iron and Steel industry. This study only discussed the direct use of energy and did not consider secondary effects (e.g., manufacture of materials used in stee lmaking).

III. Types of Information Provided

1. Energy use data were given for each process discussed.

2. Estimates of possible energy savings were given.

3. Development times for the projects were normally included.

4. Existing $R \& D$ programs in each project area were mentioned.

5. An approach for identifying the research opportunities was given. In the study, three types of conservation opportunities were examined: 1) conceptual opportunities with in each process, 2) new technologies that could replace current technologies, and 3) general technologies. To gather information, major steel companies were visted, a meeting was held with the American Iron and Steel Institute, and previous studies were reviewed. Because the time frame was less than ten years, the authors judged that major portions of any idea worth considering must have already been piloted or tested on a large scale. Cost benefit assessments were also performed for each of the processes.

IV. R\&D Opportunities

See attached sheets.

V. Critical Summary

Following a process-to-process outline, this report presented a coherent and comprehensive picture of conservation research needs in the steel industry. The projects discussed were examined technically and economically and the explanations were clear and not overburdened with technical detail.

A major drawback limiting the usefulness of this report to the ECUT project is the short time frame of the report: less than 10 years. This caused the authors to rely on technologies which have already been demonstrated on a large scale. Therefore, untested or sparsely tested ideas, regardless of the ir merit and possible impact on energy conservation in the longer term, were not investigated. 


\section{Comments}

The literature reviewed to aid in compiling this report is listed below:

- "Energy Conservatin in the Steel Industry," by American Iron and Stee 1 Institute, 26 May 1976;

- "Evaluation of the Theoretical Potential for Energy Conservation in Seven Basic Industries," prepared for FEA by Battelle Columbus Laboratories, 11 July 1975;

- "Recommendations for Future Government-Sponsored Research and Development in the Paper and Steel Industries," prepared for ERDA by Thermo Electron Corp., August 1976;

- "Energy Use Patterns in Metallurgical and Non-Metallic Processing, Phase 8: Opportunities to Improve Energy Efficiency" (NTIS PB-26i 152) prepared for the Bureau of Mines by Battelle Columbus Laboratories, Onio, 17 September 1975;

- "Potential for Energy Conservation in Nine Selected Industries," prepared for FEA by Gordian Associates;

- "Environmental Considerations of Selected Energy-Conserving Manufacturing Process Options" (EPA-600-7 - 76-034), prepared for EPA by Arthur D. Litt le, Inc., December 1976;

- "Steel and the Environment - A Cost Impact Analysis," prepared for the AISI by Arthur D. Litt le, Inc., May 1975;

- "Risk/Rate of Return Tradoff Analysis: A Case for Federal Support" (draft) prepared for ERDA by Energy and Environmental Analys is, Inc., 30 August 1976.

Reviewed by GJH. 
TABLE I-1

MAJOR ENERGY CONSERVATION OPPORTUNITIES FOR ENGINEERING DEVELOPMENT IN IRON AND STEEIMAKING •

Sector

Examples of Energy-

Conserving Technology
Minimum Total Funding
to Demonstrate a New
Technology
(s Millions)

Reheating, Including

Annealing

Coke Making

Monobeam furnace (B)

Better heat recuperation (B)

Furnace using direct coal

firing rather than gas

or oil (A)

Improved forge furnace

efficiencies (C)

Waste heat recovery in

annealing (C)

Blagt Furnace

Coal injection (A)

External desulfurization (A)

Reducing gas injection to stack (A)

Dry quenching (A)

Form coke (A)

More Scrap Use in

steelmaking.

Including Pre-

heating Technologies

Co collection from BOF for scrap preheating (A)

Electric arc furnace scrap

preheat (B)

Coal-based Gasifier/

Burner

Blast gasifier (A)

New coal burner (A)

Yield Improvement:

Conserving slab heac Hot inspection, and spot

scarfing (A)

Casting and Rolling Continuous casting of pre-

forms like beam blanks (B)

$$
15-25
$$

$15-50$

$1-20$

$5-10$

$5-25(?)$

$15-25$

$30-100$

$1-10$

$1-5$

$20-60$

$1-40(?)$

$50-100$
$1-10(?)$
Comments

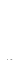

(a)

(a)

Engineering problems need to be resolved

(a)

(a)

(a)

Demonstration needed on

a continuous basis

potentially interesting if

economic coal gasifier developed

U.S. demonstration of foreign

technology needed

Medium Btu by-product

gas process desirable

cood engineering

concept needed

Good engineering

concept needed

$$
\text { (a) }
$$

Sulfur and ash

removal needed

from hot gas stream

Research and development

required

New semi-finished steel forming

technology requires conceptual

development and demonstration.

ISlab, bloom, and billet cast-

ing need economic incentives

for implementation.)

(A) Potential for national energy conservation of 50-500 × $10_{12}^{12} \mathrm{Btu} / \mathrm{yr}$.

(B) Potential for national energy conservation of $5-50 \times 10_{12}^{12} \mathrm{Btu} / \mathrm{yr}$.

(C) Potential for national energy conservation of $0.5-5 \times 10^{12} \mathrm{Btu} / \mathrm{yr}$.

(a) Reasonable to moderate extrapolation of currently available technology 
TABLE I -2

EXAMPLES OF OTHER ENERGY CONSERVATION

OPPORTUNITIES IN THE IRON AND STEEL INDUSTRY

\begin{tabular}{|c|c|c|c|}
\hline sector & $\begin{array}{c}\text { Example of } \\
\text { Concepts }\end{array}$ & $\begin{array}{l}\text { ergy } \\
\text { ervation } \\
\text { ential* }\end{array}$ & Comments \\
\hline Agglomeration & $\begin{array}{l}\text { Conversion from } \\
\text { natural gas or } \\
\text { fuel oil to } \\
\text { coal in pellet- } \\
\text { izing plants }\end{array}$ & B & Technology established \\
\hline $\begin{array}{l}\text { Grinding of } \\
\text { Iron Ore }\end{array}$ & $\begin{array}{l}\text { Improvement in } \\
\text { particle class- } \\
\text { ification }\end{array}$ & B & $\begin{array}{l}\text { Small improvements } \\
\text { over time }\end{array}$ \\
\hline $\begin{array}{l}\text { Electric Arc } \\
\text { Furnace }\end{array}$ & Modeling & B & $\begin{array}{l}\text { Small improvements } \\
\text { over time }\end{array}$ \\
\hline $\begin{array}{l}\text { Basic oxygen } \\
\text { Furnace }\end{array}$ & $\begin{array}{l}\text { Utilization of } \\
\text { Bof off-gases } \\
\text { other than for } \\
\text { scrap preheating }\end{array}$ & B & $\begin{array}{l}\text { co gas collection } \\
\text { technology estab- } \\
\text { lished, but an } \\
\text { economic system for } \\
\text { use of co is still } \\
\text { to be devised }\end{array}$ \\
\hline $\begin{array}{l}\text { Flue Dusts and } \\
\text { sludges }\end{array}$ & $\begin{array}{l}\text { Recovery of metal- } \\
\text { lic and carbon } \\
\text { values }\end{array}$ & B & $\begin{array}{l}\text { An important problem } \\
\text { relating to waste } \\
\text { disposal }\end{array}$ \\
\hline Ladle Preheating & $\begin{array}{l}\text { More efficient } \\
\text { ladle preheater }\end{array}$ & B & $\begin{array}{l}\text { Logistical and engi- } \\
\text { neering problem }\end{array}$ \\
\hline $\begin{array}{l}\text { Direct Reduc- } \\
\text { tion }\end{array}$ & $\begin{array}{l}\text { Steam coal or lig- } \\
\text { nite based pro- } \\
\text { cess }\end{array}$ & A & $\begin{array}{l}\text { Conserves metallur- } \\
\text { gical coal; process } \\
\text { development expected } \\
\text { to be capital-inten- } \\
\text { sive }\end{array}$ \\
\hline $\begin{array}{l}\text { Lime Manufac- } \\
\text { ture }\end{array}$ & $\begin{array}{l}\text { oxygen use in lime } \\
\text { kilns; fluid bed } \\
\text { process }\end{array}$ & B & $\begin{array}{l}\text { Most applications would } \\
\text { be outside of steel } \\
\text { industry }\end{array}$ \\
\hline
\end{tabular}

Agglom
Grindi
Iron
Electr
Furna
Basic
Furna
Lume Mare
ture
Sludge

A: Potential for national

$B$ : Potential for national 
TABLE I-3

OTHER MAJOR ENERGY CONSERVATION

OPPORTUNITIES USEFUL TO THE IRON AND STEEL INDUSTRY

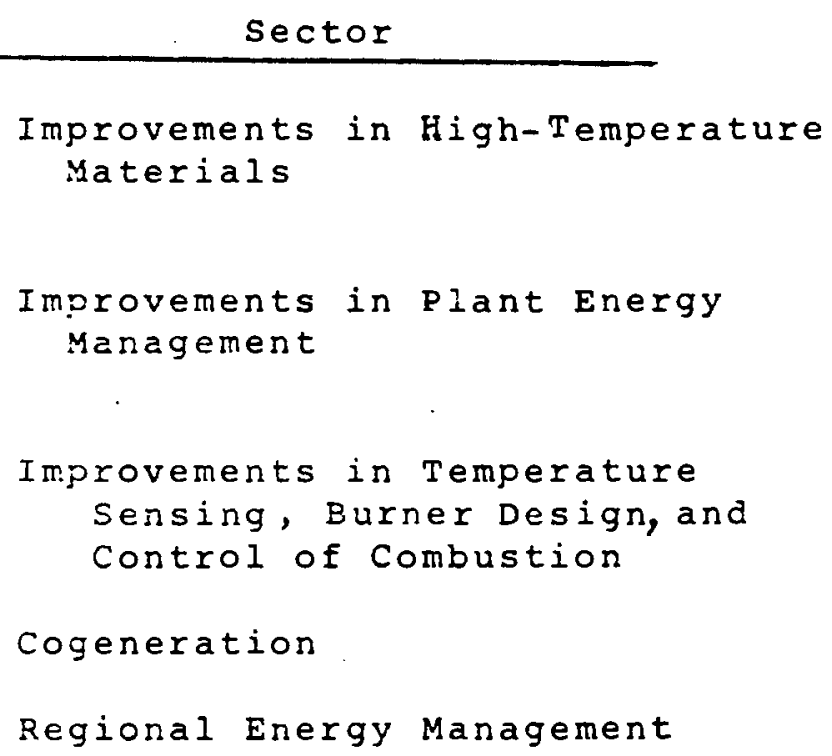

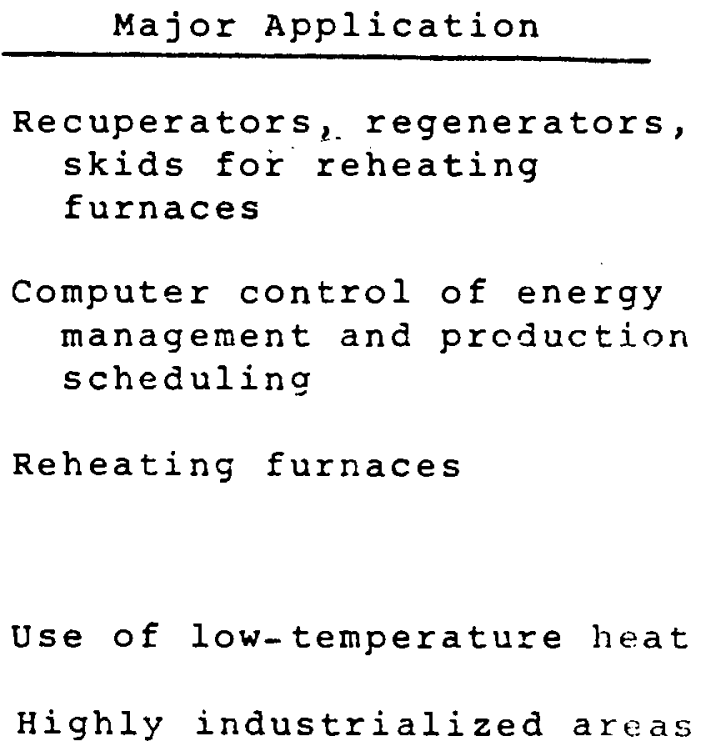



- Report No. 3

I. Aerodyne Research, Inc. An Assessment of the Potential Impact of Combustion Research on Internal Combustion Engine Emissions and Fuel Consumption. PB-0290953. Aerodyne Research, Inc. Bedford, MA, January 1979.

II. Technical and/or End-Use Focus

The technical focus is on automotive combustion engines.

III. Types of Information Provided

1. No review of end-use data was made.

2. No estimates of energy savings from research were made.

3. The report recommended a level of effort for the various research projects suggested. As part of the level of effort a contract time was presented; however, because the research is much more basic than applied toward the commercialization of a device, times to commercialization were not included.

4. Current programs were not reviewed as the work of others directly relate to the suggested research activities.

5. No methodology presented.

IV. R\&D Opportunities

See attached pages.

v. Critical Summary

This report is a very technically or iented view at needed research in engine combustion. Quantitative estimates of potential energy savings from the suggested research was not included. Rather, justification for the research stemmed from the expressed need to optimize fuel consumption while controlling pollutants by understanding the basic combustion processes. That is, the need is assumed if optimum engine designs are desired. Meaningful energy conservation estimates may we 11 be much more appropriate after the basic processes are understood and various design changes are postulated.

Technical explanations of the need for research are included with thorough descriptions of major factors controlling fuel consumption and pollution.

VI. Comments

Reviewed by GJH. 
TABLE 7-1 SUMMARY OF RECOMMENDED RESEARCH PROGRAMS

Research

Topic/Task
Number of Contracts
Duration of Total Level of Total Expenditure Contracts (yrs.) Effort (\$K/yr.) Over Program (\$K)

1. Fluid Mechanics
a. Rationalization of Engine Fluid Mechanics

2. Chemical IKInetics and Mechanisms
a. Emissions vs. Oll Consumption Englne Meas.
b. Emissions vs. Oll Characteristics Englne Meas.

c. Oll Decomposition Modoling

d. Experimental Studies of Unregulated HC Emissions Chemistry

e. Modeling of Unregulated HC Emissions

f. Engino Modification Design and Evaluation
2 (Spark Ignition Engines) 2 (Dlesel Engines)
600 to 1000

3000 to 4200
1

1

1

2

2

2
1

2

2

5

5

3
200

200

200

200 to 600

200 to 300

1200

100 to 500
400

400

2400

1800 
TABLE 7-1 SUMMARY OF RECOMMENDED RESEARCH PROGRAMS (Cont.)

Research Toplc/Task
Number of Contracts
Duration of Contracts (yrs.) Effort (\$K/yr.)
Total Expenditure

Over Program (\$15)

3. Fuel Injection and Spray Combustion
a. Tuel Injection Dynamics Studies
2
2
b. Spray Formation Studies
c. Spray Combustion Studies
3
5
5
300
100
200 300
1000
1500

4. Fuel Characteristics and Modifications
a. Preparation and Characlerization of Test Fuels

1

1

75

75
b. Development of Exhaust Analysis Techniques

c. Laboratory Simulation Tests

d. Engine Tests

e. Data Analysis and Recommendations
2 to 3

1

1

1
2

2

2

2
60

100 
TABLE 7-1 SUMMARY OF RECOMMENDED RESEARCH PROGRAMS (Cont.)

Research

Topic/Task
Number of

Contracts
Duration of Total Level of Total Expenditure Contracts (yrs.) Effort (\$K/yr.) Over Program (\$K)

5. Cycle Modification
a. Supercharging Assossment Studies
1
1
50
50
b. Ceramic Materials Development
2
3
600
1800
c. Turibine Design
Studies
2
1
2
400
800
d. Valve Control Assessment
e. Valve Mechanization
1
50
50
Contingent on 5 a 
1. Lichtz, L.C., Internal Combustion Engines, McGraw-Hull (1951).

2. Taylor, C.F., The Internal Combustion Engine in Theory and Practice, Vol. I and II, MTT Press (1960).

3. Austin, T.C. and McFadden, J.J., "A Study of Stratifled Charge for LightDuty Power Plants," Vol. I, Ricardo \& Co., EPA-460/374-011A (October 1975).

4. Inoue, K., Ukawa, H., Fuji1, I., "Fuel Economy and Exhaust Emissions of the Honda CVCC Engine, "Combustion Sclence and Technology, Vol. 12, pp. 11 - 27 (1976).

5. Mitchell, E. and Alperstein, M., "Texaco Controlled-Combustion System Multifuel, Efficient, Clean, and Practical, " Combustion Sclence and Technology, Vol. 8, pp. $39-49$ (1973).

6. Miyake, M., Okada, S., Kawahara, Y., and Asal, K., "A New Stratified Charge Combustion System (MCP) for Reducing Exhaust Emissions," Combustion Science and Technology, pp. 29 - 46 (1976).

7. Leighton, P.A. Photochemistry of Alr Pollution, Academic Press, New York, N.Y. (1961)

8. Niki, H., Daby, E.E., and Weinstock, B., "Photochemical Smog and Ozone Reactions," Adv. Chem., 113, 16 (1972).

9. Hecht, T.A., Seinfeld, J.H., and Dodge, M.C., "Further Development of Generalized Kinetic Mechanics for Photochemical Smog, " Envir. Sc1. \& Tech. $\underline{8}, 327(1974)$.

10. Calvert, J.G., "Hydrocarbon Involvement in Photochemical Smog Formation in Los Angeles Atmosphere," Envir. Sci. \& Tech., 10, 256 (1976).

11. Chameodes, W.L. and Walker, J.C.G., "A Time-Dependent Photochemical Model for Ozone Near the Ground, "J. Geophys. Res., 81, 413 (1976).

12. Fishman, J. and Crutzen, P.J., "A Numerical Study of Tropospheric Photochemistry Using a One-Dimensional Model, " J. Geophys. Res., 82, 5897 (1977). 


\section{References (Cont.)}

13. Johnston, H.S., "Recuction of Stratospheric Ozone by Nitrogen Oxide Catalysts from Supersonic Transport Exhausts," Science, 173, 517 (1971).

14. "The Effects of Stratospheric Pollution by Aircraft," Final Report of the CIAP Program, Department of Transportation, Washington, D.C. (December 1974).

15. Calvert, J.G., "Test of the Theory of Ozone Generation in' Los Angeles Atmosphere," Envir, Sci. \& Tech., 10, 248 (1976).

16. Vuk, C.T., Jones, M.A., and Johnson, J.H., "The Measurement and Analysis of the Physical Character of Diesel Particulate Emissions," SAE Transactions, Paper No. 760131, 556 (1976).

17. Laresgoiti, A., Loos, A.C., and Springer, G.S., "Particulate and Smoke Emission from a Light-Duty Diesel Engine," Envir. Sci. \& Tech., 11, 973 (1977).

18. Spindt, R.S., "Second Year Report on Polynuclear Aromatic Content of Heavy Duty Diesel Engine Exhaust Gases, " Gulf Research and Development Co., Pittsburgh, Pennsylvania (January 1977).

19. Gross, G.P., "The Effect of Fuel and Vehicle Varlables on Polynuclear Aromatic Hydrocarbon and Phenol Emissions, " SAE, Paper No. 720210, (1972).

20. Newhall, H.K., Jetoft, R.E., and Ballinger, P.R., "The Effect of Unleaded Gasoline Composition on Polynuclear Aromatic Hydrocarbon Emissions," SAE, Paper No. 730834, (1973).

21. Zughini, N., Menglini, S., Arteconi, M., and Sezzi, F., "Polynuclear Aromatic Hydrocaroons in Vehicle Exhaust," SAE, Paper No. 7308361.

22. Blumer, M., Blumer, W., and Reich, T., "Polycycllc Aromatic Hydrocarbons in Soils of a Mountain Valley: Correlation with Highway Traffic and Cancer Incidence," Envir. Sci. \& Tech., 12, 1082 (1977).

23. Gage, S., "Precautionary Notice on Laboratory Handling of Exhaust Products from Diesel Engines," EPA Memo (November 1977).

24. Spindt, R.S., Barnes, G.J., and Somers, J.H., "The Characterization of Odor Components in Diesel Exhaust Gas," SAE, Paper No. 710605 (1971).

25. "Chemical Identification of the Odor Components in Diesel Engine Exhaust," Arthur D. Little, Inc., Final Report to CRC and NAPCA, CRC Project CAPE-7-68, HEW Contract No. CPA-22-69-63 (June 1970). 


\section{References (Cont.)}

26. Somers, J.H., and KAttridge, G.D., "Revlew of Federally-Sponsored Research on Diesel Exhaust Odors," Report No. 71-75, EPA, Ann Arbor, Michigan (July 1971).

27. Levins, P.L., Kendall, D.A., Caragay, A.G., Leonardos, G., and Oberholtzer, J.E., "Chemical Analysis of Diesel Exhaust Odor Species," SAE, Paper No. 740216, SAE Transations, 949 (1974).

28. Springer, K.J., "Investigations of Diesel-Powered Vehicle Emissions VII, !" EPA Publication, No. EPA-460/3-76-034 (February 1977 ).

29. Henein, N.A., "Analysis of Pollutant Formation and Control and Fuel Economy in Diesel Engines," Prog. Energy Comb. Sci., 1, 165 (1976).

30. Patterson, D.J. and Henein, N.A., Emissions from Combustion Engines and Their Control, Ann Arbor Science, Ann Arbor, Michigan (1972).

31. Darnall, K.R., Lloyd, A.C., Winer, A.M., and Pitts, J.H., Jr., "Reactivity Scale for Atmospheric Hydrocarbons Based on Reaction with Hydroxyl Radical, " Envir. Sci. \& Tech., 10, 692 (1976).

32. Keeling, C.D. and Rotty, R.M., "The Global Carbon Dioxide Problem," Baes, C.F., et al., Eds., Report No, ORNL-5194, Dept. of Commerce, Washington, D.C. p. 18 (1976).

33. Stuiver, M., "Atmospherlc Carbon Dioxdde and Carbon Reservoir Changes," Sclence, 197, 253 (1978).

34. Woodall, G., et al., "The Biota and the World Carbon Budget," Science, 199,14 (1978).

35. Mercer, J.H., "West Anartic Ice Sheet and $\mathrm{CO}_{2}$ Greenhouse Effect: A Threat of Disaster, " Nature, 271, 321 (1978).

36. McElroy, M.B. and McConnel, J.C., "Nitrous Oxdde: A Natural Source of Stratospheric NO," J. Atmos. Sci., 28, 1095 (1971).

37. McElroy, M.B., Wofsy, S.C., and Yung, Y.L., "The Nitrogen Cycle: Perturbations Due to $\mathrm{Man}$ and Thetr Impact on Atmospheric $\mathrm{N}_{2} \mathrm{O}$ and $\mathrm{O}_{3}, "$ Phili. Trans, Roy. Soc., 277B, 159 (1977).

38. Wang, W.C., Yung, Y.L. Lucis, A.A., Mo, T., and Hansen, J.E., "Greenhouse Effects Due to Man-made Perturbations of Trace Gases," Sctence, 194, 685 (1976). 


\section{References (Cont.)}

39. Weiss, R.F. and Craig, H., "Production of Atmospheric Nitrous Oxide by Combustion," Geophys. Res, Lett. , 3, 751 (1976).

40. Plerotti, D. and Rasmussen, R.A., "Combustion As a Source of Nitrous Oxide in the Atmosphere, " Geophys. Res. Lett., 2, 265 (1976).

41. Elkins, J.W., Kolb, C.E., and Wofsy, S.C., Unpublished results.

42. Kaplan, W.A., Elkins, J.W., Kolb, C.E., McElroy, M.B., Wofsy, S.C., and Duran, A.P., "Nitrous Oxdde in Fresh Water Systems: An Estimate for the Yield of Atmospheric $\mathrm{N}_{2} \mathrm{O}$ Associated with Disposal of Human Waste," Pure Appl. Geophys., in press.

43. Esser, J. and Laidler, K.J., "The Pyrolysis of Ethane in the Presence of Nitric Oxide," Int. J. Chem. Kinet., 2,37 (1970).

44. Schuchmann, H.P. and Laidler, K.J., "The Pyrolysis of Acetaldehyde in the Presence of Nitric Oxide," Int. J. Chem. Kinet., 2, 349 (1970).

45. Fenimore, C.P., "Formation of Nitric Oxide in Premixed Hydrocarbon Flames," Thirteenth Symposium (International) on Combustion, p. 373, The Combustion Institute, (1971).

46. Iverach, D., Basden, K.S., and Kirov, N.Y., "Formation of Nitric Oxide in Fuel-Lean and Fuel-Rich Flames, "Fourteenth Symposium (International) on Combustion, p. 767, The Combustion Institute (1973).

47. Schuchmann, H.P. and Laidler, K.J., "Nitrogen Compounds Other Than NO in Automobile Exhaust Gas," J. Air. Pollut. Cont. Assoc., 22, 52 (1972).

48. Myerson, A.L. and Blair, D.W., "Reduction of Nitric Oxide in Automobile Engine Exhaust by Ethane-Air Injection," Envir. Sci. \& Tech., 10, 461 (1976).

49. Somers, J.H., EPA Office of Mobile Source Emission Control, Research Triangle Park, NC - Private Communication.

50. Heywood, J.B., "Pollutant Formation and Control in Spark-Ignition Engines," Prog. Engr. Comb. Sci., 1, 135 (1976).

51. Cadle, S.H., Chock, D.P., Monson, P.R., and Heuss, J.M., "General Motors Sulfate Dispersion Experiment: Experimental Procectures and Results, "J. Air Pollut. Control Assoc., 27, No. 1 (1977). 
References (Cont.)

52. Chock, D.P., "General Motors Sulfate Dispersion Experiment: Assessment of the EPA Hiway Model," J. Air Pollut. Control Assoc., 27, No. 1 (1977).

53. Wilson, W.E., et al., "General Motors Sulfate Dispersion Experiment: Summary of EPA Measurements," J. Air Pollut. Control Assoc., 27, No. 1 (1977).

54. Bowman, C.T., "Kinetics of Pollutant Formation and Destruction in Combustion," Prog. Energy Combust., Science, No. 1, 33 (1ษ75).

55. Raine, R.R., Duggal, V.K., and Pratt, N.H., "A Comprehensive Review of Diesel Combustion Models for $\mathrm{NO}_{\mathrm{x}}$ and Smoke Emissions, " Consultation Report No. 108176, University of Southampton, Southampton, England (November 1976).

56. Zeldovich, Y.B., Sodovnikov, P.Y., and Frank-Kamenetski, D.A., "Oxidation of Nitrogen in Combustion," Academy of Sciences of USSR, Institute of Chemical Physics, Moscow-Lenigrad (1947).

57. Lavoie, G.A., Heywood, J.B., and Keck, J.C., "Experimental and Theoretical Study of Nitric Oxide Formation in Internal Combustion Engines," Combust. Sci. Technology, 1,313 (1970).

58. Baulch, D. L. Drysdale, D.D., Horne, D.B., and Lloyd, A.C., "Evaluated Kinetlc Data for High Temperature Reactions, " Vol. 2, CRC Press, Cleveland, Ohio (1973).

59. Sarofin, A.G. and Pohl, J.H., "Kinetics of Nitric Oxide Formation in Premixed Laminar Flames, " Fourteenth Symposium (International) on Combustion, p. 739, The Combustion Institute (1973).

60. Homer, J.G. and Sutton, M.M., "Nitric Oxide Formation and Radical Overshoot in Premixed Hydrogen Flames," Combust. Flame, 20, 1 (1973).

61. Bowman, C.T., "Investigation of NO Formation Kinetics in Combustion Processes: The $\mathrm{H}_{2}, \mathrm{O}_{2}, \mathrm{~N}_{2}$ Reaction," Combust. Sci. Tech., $\underline{3}, 37$ (1971)

62. Fenimore, C.P., "Reactions of Fuel-Nitrogen in Rick Flame Gases," Combust. Flame, 26, 249 (1976).

63. Fenimore, C.P., "Formation of Nitric Oxide From Fuel Nitrogen in Ethylene Flames," Combust. Flame, 19, 289 (1972).

64. Lyon, R.K. and Lungwell, J.P., "Selectrive Noncatalytic Reduction of $\mathrm{NO}_{\mathrm{x}}$ with $\mathrm{NH}_{3}$, " EPRI NO $\mathrm{N}_{\mathrm{x}}$ Control Technology Seminar, San Francisco (February 1976). 
References (Cont.)

65. Begeman, C.R. and Coliccl, J.M., "Polynuclear Aromatic Hydrocarbon Emissions From Automotive Engines, " SAE, Paper 700469 (1970).

66. Giger, W. and Blumer, M., "Polycyclic Aromatic Hydrocarbons in the Environment: Isolation and Characterization by Chromatography, Visible, Ultraviolet, and Mass Spectroscopy," Anal. Chem., 46, 1663 (1974).

67. Greinke, R.A. and Lewis, I.C., "Development of a Gas Chromatographic Ultraviolet Absorption Spectroscopic Method for Monitoring Petroleum Pitch Volatiles in the Environment, "Anal. Chem., 47, 2151 (1975).

68. Lavol, G.A. and Blumber, P.N., "Measurements of NO Emissions From a Stratified Charge Engine: Comparison of Theory and Experiment," Combust. Sci. Tech., $\underline{8}, 25$ (1973).

69. Lefebvre, A.H. (Ed), "Lean Premixed/Prevaporized Cobustion," Workshop at Lewis Research Center, Cleveland, Ohio, NASA CP-2016 (January 20-21, 1977).

70. "Aircraft Engine Emissions," Conference held at Lewis Research Center, NASA CP-2021 (May 18-19, 1977).

71. Roberts, R., Pectuzzi, H., and Niedzwieck, R.W., "Low Pollution Combustor Designs for CTOL Engines - Results of the Experimental Clean Combustor Program," AIAA Paper No. 76-762 (July 26-29, 1976).

72. Gleason, C.C. and Niedzwlecki, R.W., "Results of the NASA/General Electric Experimental Clean Combustor Program, " AIAA Paper 76-763 (July 26-29, 1976).

73. Tabaczynski, R.J., "Turbulence and Turbulent Combustion in Spark Ignition Engines, " Prog. Energy Comb. Sci., 2, 143 (1976).

74. Semenov, E.S., "Studies of Turbulent Gas Flow in Piston Engines," NASA Technical Transaction F-97 (1963).

75. Taylor, E.S., Personal Communication (March 1978).

76. Chigier, N.A., "The Atomization and Burning of Liquid Fuel Sprays," Prog. Energy Comb. Sci., 2, 97 (1976).

77. Samson, R., Bedeaux, D., Saxton, M.J., and Deutch, J.M., "A Sample Model of Fuel Spray Burning I: Random Sprays," Combust. Flame, 31. 215-221 (1978). "A Sample Model of Fuel Spray Burning II: Linear Droplet Streams," Combust. Flame, 31, 223 (1978). 
References (Cont.)

78. Jones, A.R., "A Review of Drop Size Measurement - The Application of Techniques to Dense Fuel Sprays, " Prog. Energy Comb. Scl., 3, 225 (1977).

79. Faeth, G.M., "Current Status of Droplet and Liquid Combustion," Prog. Energy Comb. Scl., 3, 191 (1977).

80. Charles, R., Private Communication, 1977.

81. "A New Approach to Varlable Displacement, " Automotive Ener., 85, 30 (May 1977).

82. Bryzik, W., "Adabatic Diesel Engine," Research/Development, (January 1978). 

- Report No. 4

I. American Institute of Physics. Efficient Use of Energy: AIP Conference Proceedings No. 25. American Institute of Physics, New York, 1975.

- funding by National Science Foundation, Federal Energy Administration and Electric Power Research Institute.

II. Technical and/or End-Use Focus

Technically, this report concentrates on Physics-oriented research that $c$ an contribute to energy efficiency. In end-use terms, it concentrated on energy use in buildings, the automobile, and selected industrial processes.

III. Types of Information Provided

1. Energy use in broad sectors as well as specific devices was reviewed.

2. Report did not identify the conservation potential for individual research tasks. Broad efficiency improvements that are possible were identified for many areas, however.

3. No estimates of times to commercialization were made.

4. No review of existing research programs was made.

5. The report used a 2 nd 1 aw approach to indicate areas of large potential improvement and then examined areas of knowledge that could be improved to increase efficiencies in these areas.

IV. R\&D Opportunities

SECOND LAW EFFICIENCY (p. 9).

(1) Systematic investigation of points of entropy increase in energyusing systems.

(2) Calculations of second-law efficiencies for industrial processes with a view to identifying the most fruitful areas for technical improvement.

(3) Systems studies of the cascading of heat energy in specific industries.

(4) Classification of processes according to the minimum required energy quality with a view to better matching of energy source and energy use.

(5) Interdisciplinary investigation of more sophisticated procedures of energy and entropy accounting.

Second Law Efficiency provides a norm or standard of performance against which present use of energy can be evaluated. This is crucial for determining allocation of funding for research ( $p .5)$.

References:

C. A. Berg, "Conservation in Industry", Science '84, 264 (19 Apri1 1974). 
Federal Power Commission, A Technical B asis for Energy Conservation, staff report FPC/OCE /2 (U. S. FederalPower Commission, ApriT 1974).

J. H. Keenan, E. P. Gyf topoulos, G. H. Hatsopoulos, "The Fuel Shortage and Thermodynamics", in Proceedings of the MIT Ener gy Conference (MIT Press, Cambridge, MA, 1973).

BURDINGS (p. 9-11)

\section{(A) Energy Management}

(1) Studies of heat transport over long distances (including heat transported as chemical potential energy).

(2) Systems analysis of district systems to supply both heat and electricity to a building or a group of houses.

(3) Systems studies of house-scale heat and electricity systems based on fuel cells (possibly ones deliberately chosen to have low electrical efficiency).

(4) Extensive data gathering and modeling of energy-use patterns of existing houses and buildings of various types.

(5) Research on heat storage for better load averaging of both solar and electric power.

(B) Thermal Properties of Buildings

(1) More flexible computer modeling to include the effect of wind.

(2) Measurement and modeling of thermal response functions of buildings.

(3) Investigation of building materials with large specific heats.

(4) Theoretical and experimental studies of external features, including sun control and surfaces of variable reflectivity.

(C) Insulation

(1) Theoretical modeling together with experimental studies to select new materials and filler gases, to control cell size, and to enhance fire resi st ance.

(2) Investigation of a "thermal diode".

(3) Development of layered material with variable, controllable conductivity.

(4) Development of window coatings to control heat loss.

(5) Optimization of insulation for the distribution of space heat.

(D) Aerodynamics

(1) Outside: studies of micrometeorology, wind effects on heat transfer and infiltration, control of local air flow patterns. 
(2) Inside: development of methods to control air flow, especially near walls, windows, and ducts.

(3) General: microscopic studies, experimental and theoretical, of heat transfer at solid surfaces bounded by moving air.

(E) Air Conditioning

(1) Broad search for new techniques using heat to power air conditioners; experimental studies of absorption and absorption cycles.

(2) Search for new desiccants, especially with a view to lowering the regenerati on temperature.

(3) Systems studies of groundwater cooling.

(4) Interdisciplinary studies of ground-water hydrology for heat-transfer applications.

(F) Space-Heating

(1) Continued research on heat-pump cycles and technology to extend the useful temperature range.

(2) Systems studies of solar-assisted heat pumps.

(3) Systems studies (and hydrology) of using ground water as the lowtemperature reservoir of a heat-pump syst em.

(4) Basic heat-transfer studies at solid-fluid interfaces, with a view to decreasing $T$ across heat exchangers working not far from ambient temperatures.

(G) Hot Water

(1) Detailed measurements and modeling of patterns of hot-water heating and use in houses and buildings.

(2) Systems studies of heating or "boosting" water at the point of use.

(3) Continued development of solar hot-water heating systems.

(H) Lighting

(1) Basic research on gas discharges and on fluorescence with a view to increasing the efficacy of light sources and controlling the color.

(2) Development of small and/or screw-in fluorescent lamps (mostly engi neering).

(3) Development of efficient $\mathrm{kHz}$ power supplies and further studies of frequency-dependence of fluorescent-lamp efficacy.

(4) Interdisciplinary studies of lighting needs for various tasks--intensity, uniformity, spectral distribution. 
(5) Explorati on of more effective ways to use sunlight indoors.

\section{(I) Instrumentation}

(1) Development of easy-to-use local heat flux meter.

(2) Development of cheap home instruments for monitoring and control, such as a clock-programmed thermostat, a degree-days-per-gallon meter (with suitable time averaging) and an on-line monitor of furnace burner efficiency.

(3) Packaging of a meter to measure air exchange rate in a rom or a building.

(4) The development for 1 arger buildings of on-line monitoring of several features of air quality coupled with control of reconditioned air vs. fresh air; the development of devices to recondition air.

(5) Development of infrared equipment for diagnostic studies of houses. 
THE AUTOMOB ILE (pp. 11, 12)

(A) The Power Plant

(1) Basic studies of the combustion process; development of advanced combustion diagnos tic techniques (see APS 1974b).

(2) Continued research on external combustion engines (Rankine, Stirling).

(3) Continued research on small diesel engi nes, to reduce their weight, noise, smoke, and odor.

(4) Studies of a variety of hybrid power plants (small internal combustion engi nes plus a source of boost power).

(5) Extended studies of fuel emulsions and novel fuels (see APS 1974b).

(B) Energy S torage

(1) Further systems studies of harnessing braking energy with a dynamotor.

(2) Basic research on rechargeable batteries (see Electrochemical processes, below).

(3) Experimental and theoretical studies of flywheel storage.

(C) Weight

(1) Exploration of lighter automobile structural materials.

(2) Studies of the crashworthi ness of lighter (not necessarily smaller) cars.

(D) Tires and Suspension

(1) Basic studies of viscoelastic materials and exploration of radically new tire designs.

(2) Exploration of tradeoffs in function among tires, wheels, and suspension, with a view to increasing the role of the suspension and decreasing that of the tire, to preserve ride and safety while decreasing rolling resistance.

(E) Air Drag

(1) More elaborate studies, experimental and theoretical, of automobile (also truck) air drag, including the effect of relative motion of the vehicle belly and the road.

(F) Instrumentation

(1) Development of a sophisticated yet inexpensive miles-per-gallon meter capable of integrating over various times or distances.

(2) Implementation of other mon itoring meters of engine efficiency, fuel flow, automatic-transmissi on gear. 


\section{(G) Accessories}

(1) Development and refinement of heat-powered air conditioners for automobiles and trucks.

\section{(H) Automobile References}

TEP, Research and Development Opportunities for Improved Transportation Energy Usage, summary of the Transportation Energy Panel, report No. DOT-TSC-0ST-7314 (U. S. Depar tment of Transportati on, September 1972.)

NAS, An Evaluation of Alternative Power Sources for Low-Emission Automobiles (Nati onal Ac ademy of Sciences, Washington, D. C. 1973).

INDUSTRIAL PROCESSES (pp. 12, 13)

\section{(A) Electrochemical Processes}

(1) Basic research on the physics of charge transfer at electrolyte-electrode interfaces.

(2) Basic physical studies of the principles of solid electrolytes.

(3) Continued search for rechargeable batteries of greater energy density.

(4) Basic research on all aspects of surface phenomena, especially as applied to fuel-cell performance.

\section{(B) Photochemical Processes}

(1) Exploration of catalyzed solar photolys is of water.

(2) Continued studies of the semiconductor physics of photovoltaic cells.

\section{(B) Physical Processes}

(1) Studies of adsorption techniques for molecular separation.

(2) Basic research on transport in membranes.

(3) Careful studies of the energy inefficiencies in ore benefication and water desalination to seek ways to approach more closely the min imum separative work.

(D) Heat Transfer

(1) Basic studies of heat transfer at interfaces--the role of convection, the role of surface irregularities.

(2) Basic studies of boiling.

(3) Fundamental investigati on of two-phase flow.

(4) More detailed disarssions of these areas are presented on pages 122-134. 


\section{Critical Summary}

The AIP Study is probably the best single study of overall energy conservati on research needs that has been performed to date. It reviews a wealth of physical data in order to highlight opportunities for energy conservati on and then addresses these opportunities through well-reasoned and detailed disussions of the technologies in question. The resulting list of R\&D needs is the most comprehensive available.

The only weakness of the study stems from the broad scope of what has been attempted. Because the list of R\&D needs is so $1 \mathrm{mg}$, the report makes a summary of needs, which while concise, tends to look like a laundry list without obvious justification in end-use terms. Upon reading the supporting text, one finds that this is definitely not the case. A great deal of analys is lays the foundation for evaluating the conservation potential for almost any piece of research that could be performed. This particular study stops short of performing this $t$ ype of specific analysis of individual res earch tasks, but provides essential input to such a project.

\section{Comments}

Ross and Williams have followed up on the AIP work and their work makes a good compani on to this study.

Reviewed by WJH. 


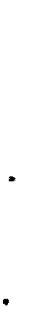


- Report No. 5

I. American Society of Mechanical Engineers. Research Needs Report:

Environmental and Conservation Research. American Society of Mechanical Engineers Task Force on Environmental and Conservation Research, American Society of Mechanical Engineers, New York, 1979.

II. Technical and/or End-Use Focus

Research opportunities focused on environmental and conservation research addressable by mechanical engineers. Conservation broken down into energy and materials.

III. Types of Information Provided

1. Little energy use data.

2. Some estimates of possible efficiency gain.

3. No estimates of time to commercialization.

4. No review of existing research.

5. No methodology presented.

IV. R\&D Opportunities

(1) Combustion - heat transfer from combustion products, combustion stability, combustion of mixtures over an extended fuel-air range, and alternate fuels are all promising R\&D topics that could improve efficiencies in highway vehicles, aircraft, rail, marine, pipeline, residential and industrial use. Examples of advanced concepts are stratified charge, prevaporizing burners in boilers and furnaces and using coal or coal-derived fuels in industrial process burners.

(2) Fuel Cells - for electric power generation using alternate fuels with improved efficiency ( 38 to $50 \%$ ). Fuel cell technology base needs to be broadened to allow fuel flexibility, lower costs, higher reliability and the development of advanced fuel cells (especially the molten carbonate fuel ce11).

(3) Alternative Engine Cycles - In particular, Stirling and closed Brayton cycle engines have varied applications including high grade heat topping, in-plant power generation, integrated and total energy systems, etc. Current engines are too costly and expensive. Critical needs are for development of low cost heat-source heat exchangers for the Brayton engine and ceramic materials for the Stirling engine.

(4) Gas Turbines - Need high efficiency, low cost, multifuel industrial gas turbines ( 5 to $25 \mathrm{MW}$ ) for integrated energy systems, pipeline pumping, marine and railway propulsion and dispersed power generation. Also need to commercialize highly efficient, heavy-fuel tolerant gas turbines ( 25 to $100 \mathrm{MW}$ ) for industrial cogeneration power plants and utility intermediate load power generation.

(5) Heat Recovery Systems (Heat Exchangers) - Development of more compact and efficient heat exchangers is needed. Corrosion resistant materials are needed. Research needs to be done on once-through 
boilers and heat exchangers for organic Rankin cycle waste heat recovery systems.

(6) High Temperature Power Cycles - Peak steam power plant temperatures are currently about $540^{\circ} \mathrm{C}$. Some of the high temperature energy available (i.e. between $2500^{\circ} \mathrm{C}$ and $540^{\circ} \mathrm{C}$ ) could be converted into electricity by devices such as the Lysholm helical screw expander or the thermionic convertor. Both device and material development is needed.

- Efficiencies:

Steam cycle

Steam cycle + thermionic

$36 \%$

Steam cycle + thermionic + MHD

$47 \%$

$62 \%$

- References:

Fitzpartrick, G. 0., E. J. Britt, "G. Carnasciali. 1977." Increased Central Station Powerplant Efficiency with a Thermionic Topping System", Proc. 12th Intersociety Energy Conversion Engineering Conference, Washington, D. C., August 1977, pp. 1602-1609.

(D) Energy Conservation in Buildings

(1) Insulation Materials - Cheaper and more efficient insulating and sealing materials. Window coatings (low infrared emissivity, or high reflectivity depending upon application. Also photosensitive coatings.

(2) Building Control Strategies - Research needed into accurate, low cost computer methods for determining building loads and transient conditions in order to select and operate energy conserving equipment for all types of buildings in any location.

V. Critical Summary

A nice laundry list with some detail, technically accurate, not well justified.

VI. Comments

R\&D opportunities presented should be considered in light of any justification attainable before prioritizing them.

Reviewed by WEG. 
- Report No. 6

I. American Society of Mechanical Engineers. Research Needs Report: Fundamental Research Needs. American Society of Mechanical Engineers Task Force on Fundamental Research, American Society of Mechanical Engineers, New York, 1978. ASME Task Force on Fundamental Research, American Society of Mechanical Engineers, New York, 1978.

II. Technical and/or End-Use Focus

Broad, non-specific focus.

III. Types of Information Provided

1. No end-use energy data were reviewed.

2. No energy savings estimate was made.

3. No est imate of time to commercialization was made.

4. No review of existing programs was made.

5. R\&D opportunities identified by singling out specific disciplines for thorough scrutiny by a task force of sufficient power. References $5,6,7,12,13,14,15$ and 16 ( 1 ist attached) deal with planning R\&D activities.

IV. R\&D Opportunities

The following R\&D areas were listed and discussed in a half page. It was intended that they be then submitted to specific discipline task forces.

- Heat transfer

- Fluid mechanics

- Materials

- Thermodynamics including combustion or reaction kinetics.

- Dynamics and control

- Tribology

V. Critical Summary

A broad brush look not necessarily complete, with no detail or justification.

IV. Comments

Broadly supports other R\&D studies.

Reviewed by WEG. 
References

(1) McC. Mathias, Charles, Jr.: Wanted: More Support for Basic Research. C\&EN, Feb. 14, 1977, p. 2.

(2) Naval Research Advisory Committee: Basic Research in the Navy. Volumes 1 and 2, June 1959. Prepared by Arthur D. Little, Inc., under Contract NONR $-2515(00)$.

(3) Anon: Technology in Retrospect and Critical Events in Science. Volumes 1 and 2, January 1969. Prepared by IIT Research Institute under Contract NSF-C535 for the National Science Foundation.

(4) Naval Analys is Memorandum DR/NAM-6, Naval Research Utility. July 1968.

(5) Anon: An Approach to the Evaluation of Basic Research Projects. NSF-C481, June 1967.

(6) Anon: A Methodological Approach to Measuring Change in Science Produced by Basic Research, NSF-C528, November 1968.

(7) Anon: A Comparative Study of the Prospective and Retrospective Approaches to the Evaluation of Proposed Basic Research, NSF C561, July 1969.

(8) Foy, Rustrum: The Unhealthy State of Basic Research. C\&EN, Jan. 10, 1977, P. 4.

(9) Editor's Page: Max Tishler on Basic Research. C\&EN March 28, 1977, p. 5.

(10) Anderson, W. J.: Fundamental Research Needs: A Status Report of the Task Force on Fundamental Research. ASME Paper 76-WA/RGPC-5.

(11) Kaufman, C. B.: The Future Social Climate for R\&D. Research Management, January 1975, pp. 29-32.

(12) Gear, A. E.: A Review of Some Recent Developments in Portfolio Modelling in Applied Research and Development. IEEE Transactions on Engineering Management, Vol. EM-21, No. 4, November 1974, pp. 119-125.

(13) Moore, R. L.: Methods of Determining Priorities in a Program of Research. IEEE Transactions of Engineering Management, Vol. EM-21, No. 4, November 1974. pp. 126-140.

(14) Verschuur, J. J., and Potjer, A. A.: Maximization of the Economic Value of Research Through Quant ifying the ReTations Between Research and the Market. IEEE Transactions on Engineering Management, Vol. EM-21, No. 4, November 1974, pp. 115-188.

(15) Havemeyer, C., and Lorentzen, R. R.: SARA-A Research Planning Tool RCA Eng. Vol. 21, No. 3, Oct.-Nov. 1975, pp. 74-77.

(16) Grossman, D. and Gupta, S. N.: Dynamic Time-Staged Model for R\&D Portfolio Planning-A Real World Case. IEEE Transactions on Engineering Management, Vol. EM-21, No. 4, November 1974. pp. 141-147.

(17) Sabersky, R.H.: Heat Transfer in the Seventies. Journal of Heat and Mass Transfer, Vol. 14, pp. 1927-1949. 
- Report No. 7

I. Anderson, Carl J. Research and Development Needs for Transportation. Lawrence Livermore Laboratory, Aprit 10, 1975.

II. Technical and/or End-Use Focus

As implied by the title, this document is concerned solely with the transportation end-use sector.

III. Types of Information Provided

1. Transportation end-use data from 1971 were reviewed.

2. No estimates of energy savings from research were made.

3. The author looks toward a time to commercialization of 20-25 years for the research project.

4. Apparently few programs existed at the time and those that did were sparsely funded. Thus, existing programs were not reviewed.

5. No methodology for identifying R\&D opportunities was given.

IV. R\&D Opportunities

(1) Alternate fuels.

(2) Electric vehicles.

V. Critical Summary

This article was written in the wake of the first oil embargo and hence is a report advocating the redirection of programs estimated when oil was cheap and copious. The author does not attempt to deal with specific research needs.

To justify government involvement the author notes the heavy automotive use of fuel oil in 1971 and he notes that recent innovations (stratified charge, disc brakes, automatic transmissions, power steering, rotary engines, radial tires, etc. ...) have come from outside the U. S. auto industry.

The title R\&D Needs for Transportation is perhaps a misnomer since few needs were identified other than the need for a more efficient engine. Since the report dealt primarily with the general need for more research, a more appropriate tit le might be "The Need for Government Sponsored R\&D in Transportation".

IV. Comments

Reviewed by GJH. 


\section{REFERENCES}

1. Secretary Kissinger, Dept. of State Bulletin, 12/2/74.

2. Anderson, et al. An Assessment of U.S. Energy Options for Project Independence. LLL, Sept. 1, 1974.

3. Energy Conservation in the U.S.: Short Term Potential 1974-1978, National Petroleum Council (March 1974).

4. Project Independence Report, Federal Energy Administration (Nov. 1974).

5. Federal Research and Development Program Plan for Transportation Energy Conservation, DOT-OST-TST-74-16, May 21, 1974.

6. Hearings and Research on Ground Propulsion Systems Subcommittee on Space Science and Applications, Feb. 4-6, 1974 (quoted in No. 8).

7. P. Chenea at a Meeting of the GM Public Policy Committee, 1970, (quoted in No. 8).

8. FEA Energy R\&D Office, "The Role of the Federal Government in Automotive R\&D", 11/6/74.

9. D. L. Ray, "The Nation's Energy Future", Dec. 1, 1973 WASH 1281.

10. "ERDA Contingency Study - New Automotive Power Systems", July 1974, AEC. 
- Report No. 8

I. Battelle Columbus Laborator ies. Developing a Maximum Energy Efficiency Improvement Target for SIC 28: Chemicalsand Allied Products. Vol. I. Draft Target and Support Document, Battelle Columbus Laborator ies, Columbus, Ohio. July 1976. Sponsored by FEA.

II. Technical and/or End-Use Focus

The focus of the study is to develop an energy conservaton target for the chemical and allied products industries which could be met by 1980 . The emphasis was on determining near-term applications that could save energy, rather than determining where R\&D could save energy in the long run.

III. Types of Information Provided

1. Fuels and electricity consumed in 1972 are given for each of the 4digit industries within SIC 28. Some analyses showing energy use by unit operation are also given.

2. Specific savings from R\&D were not identified.

3. No times to commercializatin were given.

4. No reserch programs were reviewed.

5. No methodology for identifying R\&D opportunities was presented.

IV. R\&D Opportunities

1. Process development for polymer production in SIC $2821,(\mathrm{pg} .84)$.

2. Developing less energy intensive processes for synthetic rubber production ( $\mathrm{pg} .88$ ). Rubber production via slurry or bulk reaction could be significantly less energy intensive than solution processes currently used.

- Potential saving of $50 \%$ of energy used in solution processes.

3. Specialized catalysts for solution processes (pg. 89).

- Energy used in polymerization of butadiene can be reeduced $50 \%$ by proper catalyst selection, which may be a representative figure.

V. Critical Summary

The report is very comprehensive in its treatment of the near-term energy conservation potential with in SIC 28. The level of detail in identifying where conservation is possible with in each 4-digit industry is good. Because R\&D does not generally have an impact on energy conservation in the short run, very few R\&D opportunities are described. 
The reviewed report was a draft that was assembled on a tight schedule. The authors point out that data available for estimating energy conservation potential were scarce, and that in many cases, inconsistency occurred in the data that were available.

\section{Comments}

The energy consumption and other information in this report would be useful to a future study directed specifically at identifying R\&D opportunities for SIC 28.

Reviewed by TAW. 
- Report No. 9

I. Battelle Columbus Laboratories. Implementation of Energy Conservation Technology in the Steel Industry. VoTs. I and II. Battelle Columbus Laboratories, Columbus, OH, August 1980.

\section{Technical and/or End-Use Focus}

As implied by the title, the focus of this report was on the steel industry. The study did not consider the mining of ore but did include all steps from the attainment of the ore to the shipping of the final product.

\section{Types of Information Provided}

1. End-use data relating to processes in the steel industry were reviewed.

2. Potential energy savings were thoroughly investigated.

3. Rough estimates of commercialization times were of ten given.

4. Existing programs were reviewed.

5. The project identification methodology was clearly described. Initially, previous studies were reviewed and contacts were made in the steel industry to generate a list totaling 93 potential projects. The first screening criteria consisted of two parts:

(1) The potential technology must conserve, or allow a fuel switch from a critical fuel to a less critical fuel of, at least 0.01 Quad. per year, and

(2) the technology must be capable of commercialization by 1985 . The first screening step reduced the candidate technologies to 23 . In the second screening, the candidates were analyzed in greater depth use four additional criteria:

(1) potential to conserve energy,

(2) Tevel of investment required,

(3) user benefits, and

(4) other influences (regulatory, social, environmental, etc.)

The technologies were rated on a scale from one to five using each criteria and the product of the four scores yielded the overall rating. These scores were used as an aid, not a determinant, in narrowing the field further to seven technologies. This mode was chosen as a result of recognizing that the method of ranking was imperfect and that other factors may affect the appeal of a technology. These seven technologies were then evaluated relative to each other with consideration given to:

(1) energy benefits,

(2) costs to industry,

(3) operational risks, and

(4) timeliness.

As a result of this final comparison, three technologies were recommended. 
IV. R\&D Opportunities

Three technologies were recommended from the 93 considered. These suggestions were:

(1) - Energy Management by Computer Modeling and Control ( $p .3-2,8-31,9-$ 1).

This project was recommended because of its high overall apppraisal. The principals are we 11 known and generic, but the application is very specific.

- The potential estimated energy savings are 0.20 Quad per year and the probable savings by 1985 above that which would be expected to occur without this program are 0.006 Quad per year.

- The implementation time is by 1985 .

Current programs inc Tude:

- In land Steel's energy model (p. 9-3).

Kashima Steel's energy management system ( $p .9-4)$.

Purdue University systems control (p. 9-13).

(2) - Improved Forge Furnaces (p. 10-1).

This project was also selected due to its high overall appraisal. The technology is applicable to thousands of units and many forging businesses which qualify as small businesses.

- The potential energy savings are 0.10 Quad per year and the probable savings by 1985 above that which would be expected to occur without this program are 0.042 Quad per year.

- The implementation time is by 1985 .

- Hague International design (p. 10-1).

(3) - High-Temperature Recuperators (11-1).

- Current recuperators are limited by temperatures we 11 below those available in waste streams.

- The maximum potential energy savings are 0.05 Quad per year and the probable savings by 1985 above that which would be expected to occur without this program are 0.01 Quad per year.

- The implementation time is by 1985 .

V. Critical Summary

The approach used to identify the energy conserving technologies was clearly and thoroughly explained. The authors emphasized the necessity of soliciting input from the steel industry both to better insure a comprehensive list and understanding of the technologies and to facilitate acceptance of the report with in the industry. 
Since the study was concerned with the near term implementation of a few projects, the limiting time frame quickly excluded technologies of interest to ECUT. In the first screening step, technologies which could not be implemented by 1985 were omitted from further evaluation. Thus ECUT candidate technologies were only treated cursorily.

The short time frame also necessitated that only proven technologies warrented consideration. Research and development needs were not included in the selection process while market penetration was a major factor.

In responding to the task of identifying three of the most promising technologies which can save a significant amount of energy by 1985, the authors chose a logical methodology and produced a lucid and well documented report.

VI. Comments

Reviewed by GJH. 


\section{ATTACHMENTS}

Some of the companies known to be manufacturing and/or conducting research, development, and demonstration work on high-temperature recuperators are:

\section{Ceramic Recuperators}

British Steel Corporation, England

Coors Porcelain Company, Golden CO

Genera 1 Atomic, San Diego CA

GTE Sylvania, Towanda PA

Hague Internationa l, South Portland ME

Midland Ross Corporation, Toledo $\mathrm{OH}$

Priest Furnace Ltd., England

Solar Turbines, San Diego CA

Terra-Tek, Salt Lake City UT

Thermal Transfer Corporation, Monroeville PA

High-Temperature Metallic Recuperators

AiResearch Manufacturing Company, Torrance CA

GEF I, Krofeld, West Germany

Holcroft \& Company, Livonia MI

Institute of Gas Technology, Chicago IL

Metallurgical Engineers Ltd., London, England

Rekuperator AG, Dusseldorf, West Germany 
TABLE 8-2. STEEI INDUSTRY LAUNDRY LIST

Octobẹ 31, 1979 (Revised)

Technologies are grouped by major process segments.

Numbering was purposely not consecutive, so that additions could be inserted at the proper place at later date.

Numbers in superlor parentheses refer to references and notes at the end of the cable.

\section{Code for Step 1 Screening}

* - Survives screening. Moves to Step 2.

XI - Screened out on basis that substantial implementarion by end of 1985 is unlikely.

XE - Screened out on basis that amount of energy chat will be conserved (or swltched to a less-critical fuel) is likely to be less than 0.01 Quad annaliy.

XS - Screened out because of a special consideration. The nature of the special consideration is indicated by a supergcript described at the end of "ihis table.

Step 1 Results

XI, ZS (a)

$\star$

$\mathbf{X T}$

II

XE, XI, ZS ${ }^{(\mathrm{b})}$

XII

II, $x s^{(b)}$

$X+85(b)$

\section{Cokemaking}

(1) Formed coke ${ }^{(1)}$

(2) Charging of preheated coal to ovens $(1,2)$

(3) Dry quenching of coke ${ }^{(1)}$

(4) Automatic thermal control of coke batterles (5)

(5) Thermal stabilization of coke(5)

(6) Thin-wall coke ovens (5)

(7) Reduced-temperature coking (semcoke) (5)

(8) Partial (surface) coking (sent-coke) (5)

(continued) 
TABLE 8-2. COnEtaued

Sted 1 Resules

III

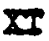

II. III

$x^{(b)}$

XE, 2x; $\operatorname{xs}^{(b)}$

*

$\star$

$\operatorname{zs}^{(b)}, \pi 5, \pi$

XI

Ex

IE

$\star$

$x^{(c)}$

III

2I

tes

$\operatorname{zs}^{(d)}$

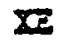

II, IS (b)

XE

$x 5^{(b)}, x$

EI, IE

$\star$

$x^{(b)}$

zc. $\mathrm{zs}^{(b)}$

•

\section{Asglomerat100 and Iromaketrs}

(11) Self-reductag agelomeraces (carbon-bear1ag) for $B F(2)$

(12) Prereduceton quftar fioel seages of aselomerazion $(5)$

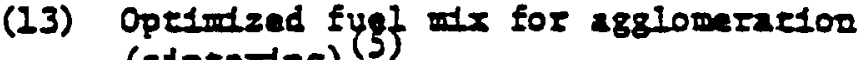
(staterlog)

(14) Subst1tution of semlcoke of char for coke broeza for agglomeratedor (5)

(15) Incover of bear from flue gas in agglomerating plang(5)

(16) Difect une of cosl in manufacture of oxtde pellets (11, 12) (zeplace oil or gas) (17) Improved statering process (HeDowell-

(21) Prebertag of $\mathrm{Ia}$ matartals to $\mathrm{BF}^{(4)}$

(22) Inproved chargarg techofiques for $B F(5)$

(23) Incrensed use of basic sincer in $B F(5)$

(24) Dse of disect reduced iron in BF burden $(2,5)$

(25) Injeceion of coel into $B F^{(1)}$

(26) Injection of hydrocarboas to $B F(5)$

(27) Infection of bot reductng gases to BF (13) zone-controlled wodified BF.

(28) Tas-bonded green briquetss charged to BF ${ }^{(5)}$

(29) Evaporartive cooling of $\mathrm{BF}^{(1,3)}$

(30) Inproved effectiveness of BF blast stoves (4)

(31) Eortehrent of BF a1s with oxygen (5)

(32) Blowing of BF with stratgite oxygei (10stead of 215$)(5)$

(33) Bell-lese cop for high-pressure BF(14, 15)

(34) Cooling of combuetsor-zone parts with serm langend of varer (sceam euperheater) (5)

(35) Use of BF rop pressure to generate Clectrict5g (1)

(36) Computer control of BF shermal and dersllurgical processes (5)

(37) Decreased slag polume (Itcher ore) (5)

(38) Segregatton of BF top gas (5)

(39) Increased zecovery of BF cop gas (5)

(Conctinued) 
TABLE 8-2. Cone1nued

Step 1 Results

20., 20, $25^{(b)}$

$\mathrm{xS}^{(\mathrm{c})}$

xe, XI, $x s^{(c)}$

XII

Xe

$X I, X E$

II

ZIE

EI

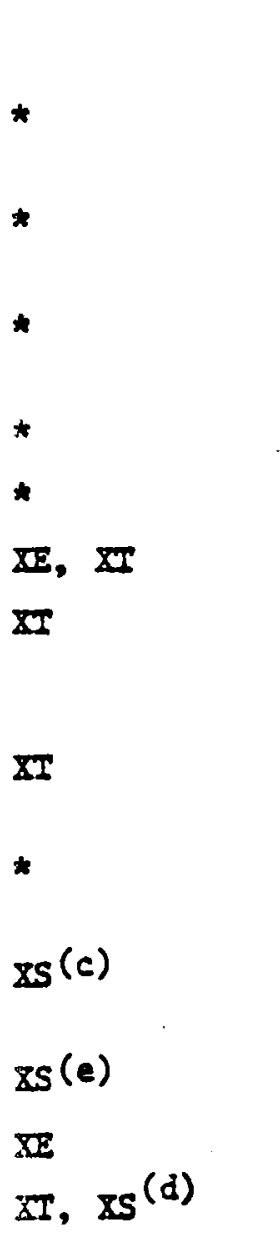

Agglomeration and Ironmak1ng Continued

(40) Stripping of $\mathrm{N}_{2}$ and $\mathrm{CO}_{2}$ from BF cop gas (5)

(41) Exteraal desulfurfzation of BF hot metal (1)

(42) Direct reduction of 1ron ore(7)

(43) Blomass as a fuel/reductant for 1ron ore ${ }^{(2)}$

(44) Hydrogen as reductant for 1ron ore(2)

(45) Alkaline carbonates aq cacalyses for reduction of 1ron ore ${ }^{(2)}$

(46) Recovery of heat from BF slags(16)

(47) Eydrometallurgfcal production of $150 \mathrm{~g}$ by electrolysis $(2,8)$

(48) Nuclear-dertyed hear for reduction of 1ron ore $(2)$

Steelmaking

(51) Increased use of BOF off gas (1) (suppressed combust10r) (52) Induction furmace superheating of $B F$
hot metal for BOF

(53) Preheating of scrap charges to steelmaking

(54) Jse of EF top gas to preheat scrap(5)

(55) Woolworth scrap preheater(17)

(56) Plasma-are steelmaktog $(2,8)$

(57) Direct (conffnuous) tronmaking/ steelmaking $(2,8)$ (ore to steel in one step)

(58) "S" process; $(8)^{\mathrm{R} \text { shaft over vertical }}$

(59) Conversion of regular-power EF's to h1gh power(18)

(60) Optintzing silicon content of bot metal from $B F(5)$

(61) Opelotizing temperature of hot metal from $B F(5)$

(62) Improved transportation of hot metal (5)

(63) Increased use of direct reduced iron ${ }^{(5)}$.

(Contsaued) 
IABLE 8-2. Conctaued

Step 1 Results

$\star$

$\star$

III
Steelmaiestog

(Conetrund)

(64) Compucer opermation of power use in Er $(3,5)$

(65) Prebarting of ladies (19)

(66) Elecerlc are furaece modification (20)
E

ET

XIr

-

$x, x^{(c)}$

$\star$

EE, II

XII

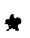

$r s(c)$

2

$\star$

跬

$25(c)$

III

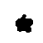

*

\section{Casting, Beating, and Bolling}

(71) Direce casting of thio-gage steel sheet $(2,8)$

(72) Conetruous theocastigg of steel stip (3)

(73) Direct rolltag of tagoes and slabs (1)

(74) Esgh-tomeracure 10specilod and surface coods $=10 \operatorname{sing}(3,5)$

(75) Iaduc $=1$ on bentso of slabs, billets, and bars (I)

(76) Monoberm slab-reherting Eurpace (1)

(77) Evaporactie cootlfo of skids in

(78) Elecerte resiotance beartag of billets (21)

(79) DC electitte Ieststance bentog of continuous sheers (22) (ValJim Corp.)

(80) N1trogeo-based earburtzing atoospheres $(3,23)$

(81) Direce Et fing for bacch werling (replace

(82) Improved slot forge furace (3)

(83) Futdized-bed beat trantwenc for pares (3)

(84) Cerame-fiber 1nsulacton $(7,24)$

(85) Stenl sheet tia powder petarlurgog $(2,8)$

(86) Bentsg furance destgons for lecreased efflclency (10) (Bolcroft MPE)

(87) Compurertzed anealing system. for barch coli mealing (10) (Engtreeriog Corp. of Amer1ea)

(Conefoued) 
TABLE 8-2. Continued

Step 1 Resulles

$\star$

XE

Xs (d)

zs (d)

XII

XI, $X S(a)$

XII

II

SI, $\mathbb{X I}$

XI

$\mathrm{zS}^{\text {(d) }}$

$\star$

$x S^{(c \cdot d)}$

*

*

$\overline{x S}(c, d)$

$\mathbf{X I}$
Foundry

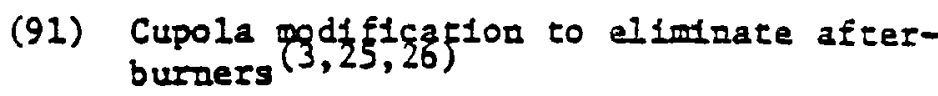
(92) Coal-fired rotary furpace for melting
1ron (replace o11) (27)

\section{General}

(101) Waste heat recovery (1)

(102) Cogeneration $(3,4)$

(103) Gasification of coal to produce fuel (2)

(104) Gasification of coal in $B F^{(9)}$

(105) Gasffication of coal to produce reducing
gas

(106) Enrtchment of combustion a1s In oxygen content (3) (by means other than addit1on of elemental oxygen)

(107) Cothane Pfocess for making rethane from

(108) Alr-fuel ratso controllers (wultiburner combus tors) (3)

(109) B1gh-temperature sensors ${ }^{(2)}$

(110) Energy management through computer modeling and control (2)

(111) Increase yield of various frod and steel processes $(7)$

(112) Yetall1c councerflow recuperators (3)

(113) Ceramic recuperators (3)

(114) Increased recycling of scrap (7)

(115) \#lgh-temerature recuperator/burner/ductizg (3)

(Continued) 
IABLE 8-2. Conc1nued

Wotes for Step 1 Screeplag (Spectal Cons 1derztor)

$\mathbf{z s}^{(a)}$

$x s^{(b)}$

$25^{(c)}$

Screnating influesed by extstence or plase for a major developwent or demonerration profect.

Subseanesal question about cechnteal feesibilit5.

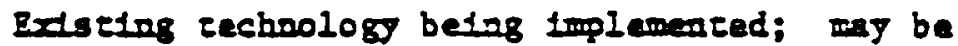
subject to restratres imposed by rechnology or

$255^{(d)}$ econowics.

$\mathbf{x s}^{(\mathbf{e})}$

Gererte techolog is recognized as appropriace but spectfies need to be developed.

A subset of Irem (52), which bas been retalned. 
References to Table 8-2.

(1) "Energg Conservation in the Steel Industry"; AISI; May 26, 1976.

(2) "Potent1al Technolog1cal Changes"; recent D.S. Government Agency report; currently restricted.

(3) "Program Description"; DOE Offlce of Industr1al Programs; Jaruary, 1979.

(4) "Prlor1ty LIstigg of Iadustrial Processes by Total Energy and Potenctal for Sarings"; Zonex Corporarton for ERDA; 1977.

(5) "The Steel Industry"; Industrlal Internat1onal Data Base, Conntitee on the Challenges of Mocern Soclety; prepared by Gordian Assoclates for ERDA, 1977.

(6) "How Induct1on Heat1ng Bypasses Energy Mess"; John J. Obrzur; Iron Age; September 10, 1979 ; pp 55-58.

(7) Battelle Columbus Division

(8) "Toward Radical Changes in Steelmakeng"; Julian Szekely; :II Technology Review; February, 1979; PP 23-39.

(11) The Bureau of Mres Looks at Coal Fir1ng for Induction of Iron Ore Pellets", Part I by Donald W. Fromer, Sk1lilings' Minlog Review, 64, No. 16, April 19, 1975;

Part II by John C. N1gro, Skillings' Minlag Review, 64, No. 17, Apri1 26, 1975.

"Preliminary Experiments in Pellet Induration Us1ng a CoalFired Cyclone Combuster"; N1gro, J. C., and Zahl, R. K.; SixtIllngs' Mlaing Rev1ew; 65, No. 24; June 12, 1976.

"Concepts for an Improved Blast Furace System"; Chaflin, B. 3.; Iron and Sreel Engtneer; November 1976; pp 25-29.

"A Study of -Improved Fuel Effectiveness in the Iron and Steel and Paper and Pulp Industries"; Gyftopoulos, E., Dullay, J. B., and ifydek, S. E.; to Nat1onal Sclence Foundat1on; by Thermo Electron Corporat1on; March, 1976; p 6-7.

\footnotetext{
"Bell-less Top for B1gh-Top Pressure Furaaces"; Heynert, G., and Legilie, E.; Developments in Irommakting Practice; Iron and Steel Institute Special Report, November 1972; No. 152.
} 


\section{Beferences}

(Concioued)

(16)

"Report of the Proceedings of the Eorerg Besenrch and Developwent Admintstration Workshop on Blgh-Tempermerara Waste Eent Recovery and Detlizat1on"; to Depertweat of Energ: by Washtrgton Sc1enctific Merkat1ng; August 25 \& 26, 1977; pp $43-44$.

(17) Iron and Steel Engtoner; July, 1979; p.33.

(18) "gnergy Dse By the Steel Indusery in North Amertca"; Group Study by Batcelle Columbus Div1ston; July 30 , 1971; PP IV-6 to 9 .

(19) Reference 16; p 44 .

(20) DOE sponsored project wh vIII; as per R. Sheneman, Octobar 10, 1979.

(21) "glectalc Conductive B11let Benters"; Betse, B. G.; Iron and Steel Engloeer; Februnry, 1977; PP 38-42.

(22) "Dlrece-Correat Blectriesl Beat Irentment of Continwous Ketel Sheets in a Protective Atmosphere"; U.S. Patent 4,081,296; March 28, 1978.

(23) Muenral Ges Prtces, Techaleal Problens Iusa Beads to K1trogen Atmospheres"; Amertcan Keeal Murket Heat Ireatiog Report; Auguat 20, 1979 ; p 18.

(24) "Lukens fights the patural gas bactle by zeductng its ezergy consumpton"; 33 vagezine; Seprember, 1976; pp 34-37.

"The Copola-Dying or Revirizg"; Hefoe, B. I.; Foundry I \& I; Juee, 1976; pP 102-109.

"Ithe Kew Economics of the Cupola"; Behder, J. E.; Foundry 4 \& I; January 1976; pp 102-109.

"Clearfield Kachtre's Coal-Fired Furace Saves on velfotg

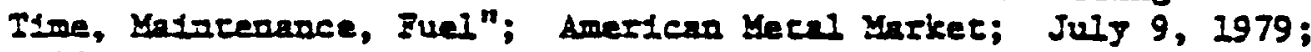
p 15.

"Potental for Energy Conservarton in the Steel Industrg"; BatrelleColumbus to Federal Energ Admirtstracton; vay 30, 1975;

Conteres No. CO-04-51874-00. NIIS \$1O. 2B 244,097/AS.

"Development and Escablishmeat of Energy Efficlency Improvement Iargets for Prtonty Ketal Indus=-1es; SIC 33"; Bartelle-

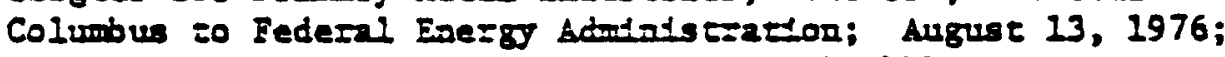

Conerace to. C0-04-60609. VIIS No. PS 269,822. 
- Report No. 10

I. Berg, Charles A. Energy Conservation in Industry: The Present Approach, The Future Opportunities. Council on Environmental Quality, May 1979.

II. Technical and/or End-Use Focus

As an example of the technological changes that can result in energy savings in industry, this report focused on the iron and steel industry.

III. Types of Information Provided

1. Energy-use data in major process steps were discussed.

2. Potential energy savings were occasionally mentioned but not always included as necessary motivation for the research.

3. Development times were occasionally estimated but were not generally included.

4. A review of relevant research programs was conducted.

5. No methodology for identifying R\&D opportunities was given.

IV. R\&D Opportunities

(1) Plasma Arc Steel Making (p. 44).

(2) Direct Steelmaking with Nuclear Energy (p. 44).

(3) Direct Electrolytic Reduction of Iron Ore (p. 44).

(4) Electrolytic Refining of Iron (p. 44)

- Smith, U.S. patent \#3,118,816

(5) Direct Electrolytic Reduction of Iron Oxides to Pure Iron (p. 44).

- Vozhova, 1966. Russian patent.

(6) Produce Electric Power During 0x-Red Reaction (p. 50) also to generate $\mathrm{H}_{2}$ as a reducing agent

(7) Powder Metallurgy (p. 57)

(8) Plasma Arc Spray Forming (p. 60)

(9) Electroforming (p. 60)

(10) Plasma Arc Steelmaking and Spray Forming together ( $p .60$ )

(11) Direct Electric Resistance Heating ( $p$. 62)

(12) Vacuum Furnace (p. 63)

(13) Coatings With High IR Reflectance and High Durability (p. 63)

(14) High Frequency Induction (p. 63) 


\section{Critical Summary}

The author asserts several times in his report that he does not attempt to be comprehensive in his treatment of conservation potential in the iron and steel industry. Rather, the focus was on the potential for conceptual advances in industry, with iron and steel chosen for illustrative purposes.

The level of detail with which the author described the projects and conceptual advances was variable. Some concepts have been known for years, some are currently being developed, and others are not being matured and are only accorded brief description.

Justification for the projects was purposely not presented solely in terms of energy saved. The author believes that defining one's acceptance criteria in that way is too limiting. Instead the author proposes that the processes be judged by the more general criteria of economic efficiency, gauging the price of energy and all other required resources. In this way, the author feels that more energy saving opportunities may be found than if saving fuel by modifying conventional technology were the primary goal. As a result savings from advanced technologies are of ten reported in terms of material saved, increased production, or increased thermal efficiency. However, since the ideas mentioned in the report were not intended as concrete research projects, justifying the projects was of secondary importance.

VI. Comments

Reviewed by GJH. 


\section{$\underline{\text { References }}$}

Arthur D. Little, Inc., Research, Development and Demonstration for Energy Conservation: Preliminary Identification of Opportunities in Iron and Steelmaking, Department of Energy Contract No. EC-77-C-03-1962, January 1978.

Berg, Charles A., and Hague Internationa1, Efficient Operation of Slot Forging Furnaces, prepared for the U.S. Department of Energy, TID-27440, 1977.

Berg, C.A., "Process Innovation and Changes in Industrial Energy Use," Science, Vol. 199, Feb. 19, 1978, pp. 608-614.

Boltz, R.K., Production Processes: Their Influence on Design, Penton Press, Cleveland, 1949.

Boorstin, D.J., The Landmark History of the American People, From Appromattox to the Moon, Random House, New York, 1970.

Chenery, E.G., "Processes and Production Functions from Engineering Data," in Studies in the Structure of the American Economy, by W.W. Leontief, New York, 1953.

Cook, Earl, "Limits to Exploitation of Nonrenewable Rescurces," Science, Vol. 191, Feb. 20, 1976, pp. 677-682.

Crestani, A.B., Neumann, J.W., and Cruse, C.L., "Status of Armco's Reduction Process," American Iron and Steel Institute Technical Session, May 22, 1974.

Dancy, T.E., "Integrated Steelmaking Sidbec-Dosco Using Direct Reduction and Electric Furnaces," American Iron and Steel Institute Technical Session, May 22, 1974.

Douglas, P.H., Theory of Wages, Macmillan, New York, 1937.

Enos, J., "Innovation and Invention in the Petroleum Refining Industry," in The Rate and Direction of Inventive Activity: Economic and Social Factors, Princeton University Press, Princeton, N.J., 1962.

EPA (Environmental Protection Agency), Environmental Considerations of Selected Energy Conservaing Manufacturing Process Options, Vol. III, Iron and Steel Industry Report, EPA-600/7-76-034C, 1976.

Gabor, Dennis, "The Scientist in the New Society," Tykotchner Memorial Lecture, University of Illinois, Champaign-Urbama, May 1, 1972. 
Hamberg, D., "Invention in the Industrial Research Laboratory," The Journal of Political Econony, Vol. LXXI, No. 2, April 1963.

Hatsopoulis, G., Widner, T., Gyftopoulos, E. and Sant, R., "A National Policy for Industrial Conservation," Thermo Electron Corporation, Waltham, Mass., 1977.

Heffernan, G.R.; "Two Routes to Steel," IEEE Conference Record of the Eleventh Bicennial IEEE Conference on Electric Process Heating in Industry, 1973.

Hogan, W.T. (S.J.), and Koelble, F.T., Purchased Ferrous Scrap, United States Demand and Supply Outlook, study prepared for the American Iron and Steel Institute, Indistrial Economics Research Institute, Fördham University, New York, June 1977.

Hotelling, H., "A General Theory of Depreciation," Journal of the Anerican Statistical Association XX, PP. 340-353, 1925.

Jewkes, J., Savens, D. and Stilerman, R., The Sources of Invention, Macmillan, London, 1958.

Lutz, F. and Lutz, V., The Theory of Investment of the Firm, Chapter VII, Princeton University Press, 1951.

National Science Foundation, Research and Development in Industry, 1975 NSF 77-324.

OTA (Office of Technology Assessment), Radically Innovative Steelmaking Technologies, a workshop held at the Massachusetts Institute of Technology, April 25, 1978, Chairman: Professor J. Szekeley.

Peck, M.J., Competition in the Aluminum Industry, Harvard University Press, Cambridge, Mass. 1961.

Pilkington, Sir Alastair, "The Development of Float Glass," The Glass Industry, February 1963, p.180 \& ff.

Pinkington, Sir Alastair, "The Float Process," Joumal of the Institute of Fuel, $\underline{252 /}$, July 1970.

Robinson, Joan, "The Production Function and the Theory of Capital," Review of Economic Studies, Vol. 21, No. 2, 1955.

RRN/A (Robert R. Nathan Associates), Iron and Steel Scrap: Its Accumulation and Availability as of December 31, 1975, prepared for the Metal Scrap Research and Education Foundation, Washington, D.C., August 1977. 
Salter, W.E.G., Productivity and Technical Change, Cambridge University Press, 1966.

Samuelson, P., Economics, McGraw Hill Book Company, Inc., New York, 1952.

Samuelson, P., Economics, 9th edition, McGraw Hill Book Company, Inc., Net York, 1973.

Smailer, R.M., Jensen, B.J., and Scott, W.W., Jr., "Utilization of Direct Reduction Iron in Electric Steel Making," American Iron and Steel Institute Paper, 22nd General Meeting, May 22, 1974.

Solow, R.Y., "Technical Change and the Aggregate Production Function," The Review of Economic's"and Statistics, Vol. XXXIX, August 1957.

Sporn, P., Technology, Engineering and Economics, M.I.T. Press, Canbridge, Mass., 1969.

Stanford Research Institute (SRI), Patterns of Energy Consumption in the Lnited States, prepared for the Energy Policy Staff, Office of Science and Technology, office of the President, Washington, D.C., U.S. Government Printing Office, 1972.

Trinks, H., and Mawhinney, M.H., Industrial Furnaces, Vol. II, John Wiley \& Sons Inc., New York, 1967.

U.S. Department of Energy, Criteria for Evaluating Conservation R\&D Opportunities, 1978.

U.S. Department of the Interior, Minerals and Materials, a monthly survey, February 1978.

U.S. Steel Corporation, The Making, Shaping and Treating of Steel, Pittsburg, 1971.

Walker, B.H., and Fuss, L.N., "Manufacturing Processes for the Production of Near Net Superalloy Disk Shapes by Isothermal Forging," AFML report IR-278-5-III, Air Force Materials Laboratory, 1976; Net Shape Metalworking Program Review, Riviera Beach, Fla., Dec. 6-8, 1976. 


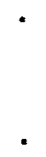

.

. 
- $\quad$ Report No. 11

I. Brookhaven National Laboratory. Future Raw Materials and Energy Use in Industry - A Research Agenda, A workshop sponsored by the Division of Industrial Energy Conservation, U.S. Department of Energy (DOE), November 910, 1978.

II. Technical and/or End-Use Focus

The focus of this report was industrial energy conservation. The research agenda is organized according to specific industries.

III. Types of Information Provided

1. No review of energy end-use data was made.

2. No estimates of energy savings were given.

3. No estimates of times to commercialization were given.

4. No review of existing research programs was made.

5. The list of research needs was prepared by industry personnel and reflects the ir knowledge of their industries but does not represent any systematic attempt at identifying needed R\&D.

IV. R\&D Opportunities

This report did not address end-use energy flows, time to commercialization, process efficiencies, or further references relating to the R\&D opportunities that were identified. Thus, items 2-5 in this outline are all empty. To save space, the R\&D opportunities that follow are presented as a laundry list organized by industry.

A. Agriculture (p.18)

(1) Germ plasm research (preservation)

(2) Photosynthetic efficiency

(3) Fertilizer efficiency

B. Forest Products, Pulp and Paper

(1) Biological, genetic improvements in trees (p.27)

(2) Improved pest control (p.27)

(3) Water removal (p.29)

- dry forming

- fundamentals of fiber - fiber bonding

- fundamentals of fiber - solvent interaction

- high consistency forming/cleaning

- high temperature forming 
(4) Drying (p.29)

- pressing

- physical displacement

- fluid displacement

- fluid displacement

- electromagnetic displacement

(5) Chemical cycle $(p .29)$

- chemistry of c'austicization

- new lime producing technology

- electrochemical regeneration using reducing power of black liquor

- plasma technology

(6) Power systems (p.30)

- fundamentals of wood combustion (gasification, cogeneration applications)

(7) Environmental (p.30)

- low level heat utilization

- low cost heat exchangers

- solid waste (sludge) utilization

- non-biological effluent treatment

C. Iron and Steel Processing

(1) Improved blast furnace process (p.38)

- distribution of gas \& solids

- modeling of fluid flow in furnace, strength of materials that go into furnace, relative size of materials, etc.

(2) Improved particle reduction (low energy) (p.38)

- pelletizing

- sintering

- cokemaking

(3) Research that supports alternatives to blast furnaces (direct reduction, plasma steelmaking, nuclear steelmaking, direct refining....) (p.39)

- problem of containment (refractories)

- basic mechanisms of oxidation \& reduction

- material requirements (severe in nuclear steelmaking)

- generating and maintaining plasma flows

- methods of applying energy, particularly electrical

(4) Impurities removal from scrap (p.40) 
(5) Environmental questions ( $p .41)$

- basic mechanisms of fume formation, fine particle technology, dust formation, gas cleaning mechanisms, slag processing, materials recovery.

(6) Solidification (form nearer to final product) (p.41)

- studies of effects on properties and processing of various heat transfer rates, cooling rates, and solidification rates

- modification of limiting factors (thermal diffusity...)

- basic properties of melts \& slurries

- formation properties of surfaces

- effects of non-uniformities such as fluid-flow, heat transfer, fusion temperature, \& compositional variations on processing and properties

(7) Heating solid steel

- pulse heating

- induction heating

- resistance heating

- basic research (electrical properties of steel, effect of heating rates \& method of energy application on properties, methods of applying energy)

(8) Alternative techniques

- powder rolling

- electrodeposition (spraying to final shape)

- projectile forming

- codeposition of alloys

D. Glass, Cement and Ceramics

(1) High temperature phase composition studies would lead to high temperature processing units ( $p .51)$

(2) More efficient heat exchangers to preheat raw materials using waste heat (p.51)

(3) Development of radically changed compound composition in cement (e.g.j) silicates and aluminates that form at lower temeratures)

(4) Develop coal gasification units so that ash, sulfur and alkalies are not added to clinker composition (p.52)

(5) High temperature filtration to use $800-900 \mathrm{~F}$ waste heat from cement plants to produce electricity (p.52)

(6) Develop small non-rotating furnaces to produce portland cement $(\mathrm{p} .52)$ 
(7) Study processes to produce high quality clinker from waste cement dust (p.52)

(8) Fundamental studies on the brittle nature of ceramic materials; success will permit use of high temperature stable materials for turbine applications yielding magnificantly higher efficiencies ( $p .53)$

(9) Innovative glass melting process research, e.g., high energy concentration in a small area and with rapid transport of batch through the zone (p.53)

(10) Fundamental studies for increasing the fuel effectiveness in firing ceramic products; some processes are only $5-10 \%$ efficient ( $p .53)$

(11) Fundamental system analysis for net process energy consumption, e.g., conversion to electricity from gas or oil for glass melting.

(12) New plants follow markets, need for local material and process variations to fit optimal model; basics of reformulation are not we 11 established and research is necessary (p.53)

(13) Utilization of waste materials, tailings, recycle, etc., (p.53)

a) fly ash

b) calcium sulfate

c) slags and scorias

d) substitution for asbestos or other materials where there are environmental problems

(14) Alkali resistant glass applicable to reinforce concrete, (e.g., reactions of cement with other filler materials) ( $p .53$ )

(15) Reaction of materials thermal or chemical prior to processing (p.53)

(16) Reliable temperature measurement process diagnostics (p.53)

(17) Understand fine particle processes and characterization techniques (p.53)

(18) Lower temperature processes (p.53)

(19) Foamed ceramic materials; high strength at low density. (Low with construction group) (p.53)

(20) Glass and steel furnace refractories research to improve vessel life and product quality

(21) Heat storage, (high temperature regenerative process) encapsulation in stable refractory material of materials which will change phases 
(22) Fundamental research on grinding processes

(23) Fundamental research on surfaces of ceramics

(24) Coating of fine mineral particles, e.g., coating of fluxing materials on aggregate materials of proper size distribution in order to develop better ceramic bodies at lower temperatures

(25) Fundamental research on fly ash

(26) Selected phase equilibrium diagrams

(27) Ability to predict fundamental properties of cement products reduces the requirement for overdesign

(28) Change in standards from composition to performance standards permits substitutional materials in cements

(29) Development of algorithms models for use in real industrial processes

E. Chemicals and Polymers

(1) Fundamental research in catalysis (p.67)

(2) Biomass conversion to chemicals \& polymers (p.67)

(3) Coal liquefaction \& gasification to provide chemical feed stocks $(p .68)$

(4) Fundamental research on corrosion (p.68)

(5) Fundamental research in surface chemistry (p.68)

(6) Utilization of government owned \& operated high energy radiation sources for chemical process research (p.68)

(7) Polymer characterization in a fundamental sense (p.68)

(8) Provide (through NBS) continuing characterization of basic physical \& thermochemical data on materials of interest to chemical \& polymer industry (p.68)

Note: Items $5-8$ are identified in the study as lower priority than items 1-4.

F. Textiles

Suggested general research areas to realize scenario of 2000 A.D. textile plant.

(1) Fiber and Raw Material

a. Maximize use of raw material

b. Separation; recovery, and reuse of fiber, chemicals 
(2) Auxiliaries

a. Improved process efficiency

b. Product modification

c. Improved in-plant environment for process control and workplace

(3) Machinery

a. More efficient machines

b. Continuous product flow

c. Retrofits for improved efficiency

(4) Process Improvement

a. New, more efficient routes from fiber to product

b. Low-energy processing

c. Reduce use of liquids

d. Compressed process lines

e. Continuous flow, improved materials handling

(5) Product Improvement

a. Improve durability, useful life

b. Improved performance

c. Individualization of basic product through finishing versus construction

Additional specific topics suggested by panelists for research attention:

(1) Development of new generic fibers from renewable resources.

(2) Optimization of fiber blends and fabric finishes for both function and ease of separation and recycling.

(3) Development of economic recycling techniques for extraction of fibrous materials from finished fabrics.

(4) Development of new end uses for textile and apparel industry byproducts.

(5) Development of new natural fibrous and auxiliary raw materials.

(6) Development of effective energy cost accounting by style, shade, etc.

(7) Improved screening and evaluation of developments and innovations, from within and without the textile industry, for possible implementation in material and energy conservation.

(8) Development of effective mechanical dewatering techniques to minimize energy required for drying (paper industry analogy).

(9) Development of pressurized hot water vs. steam for process heating systems (includes reuse of hot process liquors).

(10) Development of improved insulation and heat storage technologies to minimize heat energy requirements. 
(11) Development of automatic power factor correction techniques for individual electric motors.

(12) Control and correction of high-frequency transient peaks by Zener diodes.

(13) Improved synchronous switching of heavy electrical loads.

(14) Development of more efficient electrical motors.

(15) Improved management and control of electrical energy demand.

(16) More effective manpower training in energy-conservative skills (possible new incentives for conservation).

(17) Minimize air cooling and humidification requirements for effective material performance in processing (example: condition only material and machinery area, not entire mill atmosphere).

G. Manufacturing

(1) Coal utilization for energy \& raw materials (p.104)

(2) Cogeneration utilizing waste heat (p.104)

(3) Generic disciplines that boradly impact manufacturing (e.g., combustion research for low temps., powder metallurgy, net-shape forming, metal \& plastic forming, wear, tribology, automatic welding processes, surface coatings) (p.104-105)

(4) Long-range research on inspection, non-destructive testing, product failure, mechanism \& fracture mechanics (p.104)

(5) Factory automation, sensing \& modeling (p.104)

H. Raw Materials, Exploration and Extraction

$\underline{0 i 1}$

(1) Methods to find oil in stratigraphic traps (p.113)

(2) Ways to determine spatial distribution between drillholes of fluids (oil, gas, water) and rock (p.113)

(3) Improve ability of injected fluids to displace oil in reservoirs (p.,113)

(4) Cheaper, faster drilling (p.113)

(5) Means to mine depleted oil fields (p.114)

(6) Develop seafloor production and transport systems for use under permanent ice (p.114) 
(7) Understand behavior of rock-fluid systems in outer 10,000 meters of earth's crust (p.114)

Coal, 0il Shale, Tar Sands

(8) Means to mine thick underground seams (p.114)

(9) Develop method of partial mining followed by underground gasification (coal), retorting (oil shale), or mobilization (tar sand) (p.115)

(10) Automate underground mining (p.115)

(11) Stabilize roofs ahead of underground working faces (p.115)

(12) Enhance recovery of coal (p.115)

(13) Methods for reclaiming land that has been mined ( $p .116)$

Uranium

(14) Extraction of uranium from low concentrations (p.116)

(15) Solve support \& environmental control problems of deep sandstone deposits ( $p .116)$

(16) Improve methods of evaluating future supplies and costs (p.117) Geothermal Fluids

(17) Develop new ways to find geothermal reservoirs ( $p .117)$

(18) Means to evaluate quality of geothermal reservoirs before drilling ( $p .117)$

(19) Improved drilling technology (p.117)

(20) Predict recharging rate of a geothermal reservoir \& estimate total recoverable energy ( $p .117)$

(21) Solve problems associated with disposal or reinjection of spent brine (p.117)

Non-Energy Minerals

(22) Develop new ways of making holes in the ground (p.117)

(23) Method to cheaply, quickly, continuously assay the walls of a drilling hole (p.118)

(24) Determine distribution of desired material between holes (p.118)

(25) Improve remote exploration \& discovery tools (p.118)

- geophysical means to distinguish limestone from dolomite 
- geophysical means to distinguish chalcopyrite from pyrite

- geophysical means of penetrating highly conducting or attenuating overburden w/o excess ive power requirements

- airborne induced polarization unit

- induced polarization unit to penetrate below 1,000 ft. \& electromagnetic unit to penetrate below $300 \mathrm{ft}$.

- means of determining breaking characteristics of rock from drill hole data

\section{Extraction}

(26) Determine rock properties \& outline ore bodies ahead of drilling or mining face by indirect methods ( $p .119$ )

(27) Reduce waste breaking, handling \& transport (p.119)

(28) Develop continuous self-adjusting mining system ( $p .120)$

(29) Bioleach ore deposits \& tight oil reservoirs (p.120)

(30) Find \& recover seafloor nodules (p.120)

\section{Processing}

(31) Develop a data bank on the physical \& chemical properties of metals \& the ir compounds ( $p .121$ )

(32) Recover valuable minerals from waste products (mill tailings, smelter dust \& slag, scrubber sludge, steel plant slag, thermal power plant ash, garbage) (p.121)

(33) Find better ways of fracturing rock ( $p .121$ )

(34) Improved understanding of fluid flow through static \& dynamic particle systems ( $p .122)$

(35) Augment understanding of the physics \& chemistry involved in mineral processing (p.122)

(36) Improve flotation \& flocculation processes by research on surface active agents (p.122)

(37) Improve separation of minerals by use of high-gradient, highfield magnets ( $p .122$ )

(38) Methods to extract minerals or metals from seawater P.122)

I. Construction

(1) State-of-art study or summary should be conducted on construction materials and methods with respect to energy utilization. An energy budget model should be developed, giving consideration to value engineering vs. energy engineering. Cost in dollars and $\mathrm{kW}$ to build, operate and salvage/recycle. Cost effectiveness vs. energy effectiveness. Emphasize energy savings

(construct vs. operate) in design (p.127) 
(2) Study of the effect of restrictive elements or labor, government, environmental, safety and codes with aim of standardization to improve energy efficiency and minimize restraints - reassess and recommend for legislation ( $p .127)$

(3) Educational input of energy effectiveness to industry and owners (p.127)

(4) Scheduling - a greater percent of engineering and purchasing should be completed before bidding ( $p .127)$

(5) Soil mechanics

- sonic quarrying, tunneling and drilling

- soil sampling

- in situ testing

- pile driving - pile replacement

- movement of earth, rock and similar materials

- earth compaction

(6) Site preparation - soil stabilization for site access (water, snow, mud consolidation)

(7) Concrete

- transportation/placement, e.g., air blown

- curing/stripping time reduction

(8) Improved tensile strength - reduced resteel, e.g., fiber concrete (p.128)

(9) Joint preparation - adhesive bonding (p.128)

(10) Strength measurement criteria and redefinition (p.128)

(11) Flammability studies - forms and scaffolding (p.128)

(12) Steel - splicing and tying methods (p.128)

(13) Material replacement (p.128)

- cement and concrete substitutions - blast furnace slag, fly ash, waste

- coatings for piping (cladding)

- aluminum wire termination research

- insulation for process industry and commercial buildings

(14) Adhesives - in lieu of welding or fasteners ( $p .128$ )

(15) Metals joining - e.g., diffusion bonding of structural steel, reinforcing steel and piping (p.128)

(16) Cutting techniques for concrete and steel using laser beams and plasma torches (p.128) 
(17) Standardized connections - electrical (p.128)

(18) Explosive techniques - safety, precision (p.128)

(19) Destructive techniques - recycling, salvage (p.128)

(20) Waste product utilization - recycling (p.128)

(21) Heat storage and conservation (p.128)

(22) Non-destructive examination techniques (p.128)

(23) Quality assurance techniques (p.128)

(24) Centralized construction - float to location (p.128)

(25) Centralized location - industrial and power parks ( $p .128)$

(26) Prefabrication - larger modules (p.128)

(27) Equipment handling systems (p.128)

(28) Instrumentation - sensing of primary elements - pressure, temperature, mo isture, 3-dimensional strain measurements (p.128)

(29) Fracture mechanics and structural analysis (p.128)

(30) Temporary power sources (p.128)

(31) Temporary heating sources - replace petroleum (p.128)

J. Non-Ferrous Metal Processing

(1) Direct reduction of aluminum (p.133)

(2) Inert anodes ( $p .133$ )

(3) Replacement of petroleum coke $w /$ coke from coal in anodes ( $p .133$ )

(4) Purification technology for recycling aluminum alloys (p.133)

(5) Develop alternative processes for extracting copper, lead, zinc, and nickel from sulfide ores (p.136)

(6) Study of impurity element distribution between slag, metal, matte and gas phases (p.137)

(7) Basic research in grinding (only about $5 \%$ efficient) (p.138)

v. Critical Summary

This report is basically a set of lists of needed research projects put together by groups of knowledgeable persons from various industries. There is no tight structure or methodology that binds the lists together. Thus, while this report presents a massive "laundry list" of industrial energy 
conservation ideas, it does not attempt to justify them in either end-use or technical terms.

VI. Comments

Reviewed by WJH 
- $\quad$ Report No. 12

I. Committee on Nuclear and Alternative Energy Systems. Energy in Transition 1985-2010. National Academy of Sciences, Washington, D.C., W.H. Freeman: San Francisco, 1979.

- funding from NAS and ERDA.

II. Technical and/or End-Use Focus

The focus of the study is on development of alternate energy supply and demand scenarios. R\&D needs come out of the discussions of demand scenarios, presented in the Report of the Demand and Conservation Panel.

III. Types of Information Provided

1. A fairly detailed review of energy use is made in the Report of the Demand and Conservation Panel and models of energy use in the various sectors are utilized to project alternate consumption scenarios.

2. Specific savings from R\&D not identified.

3. No estimates of times to commercialization were given.

4. No review of existing research programs was made.

5. Whatever methodology that was utilized was not made explicit in the reports. The R\&D needs were presented as "obvious good ideas".

IV. R\&D Opportunities

Buildings and Appliances

(1) Basic Studies of Properties of Materials (p. 117).

(2) Basic Studies of Automatic Control Technology (p. 117).

(3) Automatic Setback Thermostats (p. 117)

(4) Pilot/Burner Retrofit (p. 117).

(5) Reinsulation Methodologies (p. 117).

(6) Solar Water Heating and Passive Design

(7) Metering for Fime-Dependent Utility Pricing

(8) Automatic Ventilation Control for Building and Appliances

(e.g. clothes dryer)

(9) High Performance Electric and Heat Driven Heat Pumps

(10) Solar Space Cooling

(11) Sophisticated Appliance Controls and Integrated Appliance Design

(12) More Sophisticated Design of Buildings to Provide Desired Amenities at Low Energy Demand. 


\section{Buildings and Appliances References}

Authur D. Little. 1975. An Impact Assessment of ASHRAE Standard 90-75; Energy Conservation in New Building Design. Cambridge, Mass.: Arthur D. Little.

Bligh, T. P., and R. Hamburger. 1974. Conservation of Energy by Use of Underground Space. In Legal, Economic and Energy Considerations in the Use of Underground Space, pp. 103-118. Papers presented at a workshop organized by Standing Committee No. 3 (Demand Forecasting, Use of Sub-surface Space, Legal Requirements, and Standards), U. S. National Committee on Tunneling Technology, National Research Council, held in conjunction with the Engineering Foundation conference on Need for National Policy for Use of Underground Space, June 24-29, 1973, South Berwick, ME. Washington, D. C.: National Academy of Sciences. Available from National Technical Information Services, Springfield, Va. (PB236-755).

Cohn, S., E. Hirst, and J. Jackson. 1977. Econometric Analyses of Household Fue 1 Demands. Oak Ridge, Tenn.: Oak Ridge National Laboratory (ORNL/CON-3).

Doe 1, S. H. 1975. Energy Use and Conservation in the Residential Sector: A Regional Analysis. Santa Monica, Calif.: Rand (R-1641-NSF).

Energy Research and Development Administration. 1976. The Electrodeless Fluorescent Lamp Fact Sheet. Washington, D. C.: Energy Research and Development Administration.

Federal Energy Administration. 1976a. Technical Background Information for Appliance Efficiency Targets for Kitchen Ranges and Ovens. Draft, Washington, D. C., April.

Federal Energy Administration. 1976b. Technical Background Information for Appliance Efficiency Targets for Water Heaters. Draft, Washington, D. C., April.

Fraker, H., and E. Schorske. 1973. Energy Husbandry in Housing: An Analysis of the Development Process in a Residential Community, Twin Rivers, N. J. Center for Environmental Studies. Princeton, N. J.: Princeton University.

General Services Administration. 1975. Energy Conservation Design Guidelines for New Office Buildings. Washington, D. C.: General Services

Admin istration.

Herendeen, R. A., and J. Tanaka. 1975. Energy Cost of Living. Center for Advanced Computation. Urbana, I11.: University of I11ino is (CAC 171).

Hirst, E. A., and R. Hoskins. 1977. Energy Cost Analysis of Residential Water Heaters. Oak Ridge, Tenn.: Oak Ridge National Laboratory (ORNL/CON-10).

Hirst, E. and J. Jackson, 1977. Historical Patterns and Residential and Commercial Energy Uses. Energy 2(2):131-40.

Hirst, E., W. Lin, and J. Cope. 1976. An Engineering-Economic Model of Residential Energy Use. Oak Ridge, Tenn.: Oak Ridge National Laboratory (ORNL / TM-5470). 
Hirsh, E., J. Cope, S. Cohn, W. Lin, and R. Hoskins. 1977. An Improved Engineering-Econom ic Model of Residential Energy Use. Oak Ridge, Tenn.: Oak Ridge Nati onal Laboratory (ORNL/CON-8).

Hise, E. C., and A. S. Holman. 1975. Heat Bal ance and Efficiency Measurements of Central, Forced Air, Residential Gas Furnaces. Oak Ridge, Tenn.: Oak Ridge National Laboratory (ORNL/NSF-EP-88).

Hise, E. C., J. C. Moyers, and H. C. Fisher. 1976. Design Report for the ACES Demonstration House. Oak Ridge, Tenn.: Oak Ridge National Laboratory (ORNL / CON-1).

Hittle, D., and B. Sliwinski. 1975. CERL Thermal Loads Analys is and System Simulati on Programs. Vols. 1 and 2. Champaign, I11.: Construction Engineering Research Laboratory (Interim Report E-81).

Hittman Associates. 1972. Residential Energy Consumption: Phase 1 Report. Columbia, Md.: Hittman Associates (HUD-HAI-1).

Hoskins, R., and E. Hirst. 1977. Energy and Cost Analys is of Residential Refrigerators. Oak Ridge, Tenn.: Oak Ridge National Laboratory (ORNL/ CON -6$)$.

Jackson, J. R., S. M. Cohn, J. Cope, and W. S. Johnson. 1978. The Commercial Demand for Energy: A D isaggregated Approach. Oak Ridge, Tenn.: Oak Ridge National Laboratory (ORNL/CON-15).

Jackson, J. R., and W. S. Johnson. 1978. Commercial Ener gy Use: A Disaggregation by Fue 1, Building Type, and End Use. Oak Ridge, Tenn.: Oak Ridge Nati onal Laboratory (ORNL/CON-14).

Katona, C. 1975. Psychological Economics. New York: Elsevier Scientific Publishing $\mathrm{Co}$.

Lin, W., E. Hirst, and S. Cohn. 1976. Fuel Choices in the Household Sector. Oak Ridge, Tenn.: Oak Ridge National Laboratory (ORNL/CON-3).

Morrison, B. M. 1976. Residential Energy Consumption: Socio-Physical Determinants of Energy Use in Single Family Dwellings. Institute for Family and Child Studies. East Lansing: Michigan State University.

Moyer, J. C. 1973. The Room Air Conditioner as an Energy Consumer. Oak Ridge, Tenn.: Oak Ridge National Laboratory (ORNL-NSF-EP-59).

Mutch, J. J. 1974. Residential Water Heating: Fuel Conservation, Economics, and Public Policy. Santa Monica, Cal if.: Rand (R-1498-NSF).

Newton, G. C. 1976. Energy and the Refrigerator. Technology Review 78(3):5763 .

Peoples, G. 1975. Sealed 0 il Furnace Combustion System Reduces Fuel Consumption. Dallas: Lennox Industries.

Peterson, S. R. 1976. Economic Optimization in the Energy Conservation Design of Single-Family Housing. Draft for Discussion at the American Society of 
Heating, Refrigerating, and Air Conditioning Engi neers (ASHRAE) Symposium, Dal 1 as, February 1-5.

Pilati, D. A. 1975a. The Energy Conservation Potential of Winter Thermostat Reducti ons and Night Setback. Oak Ridge, Tenn.: Oak Ridge Nati onal Laboratory (ORNL -NSF -EP -80).

Pilati, D. A. 1975b. Room Air Conditioner L if et ime Cost Considerations: Annual Operating Hours and Efficiencies. Oak Ridge, Tenn.: Oak Ridge Nationa 1 L aboratory (ORNL -NSF-EP-85).

Pilati, D. A. 1976. Residential Energy Savings Through Modified Control of Space-Conditioning Equipment. Energy 1(3).

Salter, R. G., R. L. Petruschel1, and K. Wolf. 1976. Energy Conservation in Non-Residential Buildings. Santa Monica, Calif.: Rand (R-1623-MSF).

Shick, W. L. and R. A. Jones. 1976. The Illinois Lo-Cal House. Small Homes Council, Building Res earch Council. Urbana, I11.: University of I11inois.

Socolow, R. H. 1976. Energy Conservation in Existing Residences: Your Home Deserves a House Cal1. Paper presented at the Conference on Ener gy Efficiency as a National Priority, Washington, D. C., May 20.

Thompson, P. T., and I. Mactavish. 1976. Ener gy Problems: Public Beliefs, Attitudes, and Behaviors. Urban and Environmental Studies Institutes. Allendale, Mich.: Grand Valley State College.

U. S. Department of Commerce. 1975a. Projections of the Number of Households and Families: 1975-1990. Population Estimates and Projections, Series P-25, No. 607 . Bureau of the Census. Washington, D. C.: U. S. Government Printing 0 ffice.

U. S. Department of Commerce. 1975b. Projections of the Population of the United States: 1975 to 2050. Population Est imates and Projections, Series P25, No. 601. Bureau of the Census. Washington, D. C.: U. S. Government Printing Office.

Wheeler, J., M. Grabaud, and J. P. Acton. 1975. How Business in Los Angeles Cut Energy by 20 Percent. Santa Monica, Calif.: Rand ( $p-5417)$.

Wurm, J., G. Panikker, and W. Staats. 1976. Sea sonal Performance Evaluation of Smal1 Engi ne-Driven Heat Pumps. Chicago: Institute of Gas Technology.

\section{Transportation}

(1) Basic Studies of Materials Properties (e.g. strength-to-weight) (p. 117).

(2) Thermodynamics of Internal/External Combustion Engines (p. 117).

(3) Chemical Ener gy Storage (p. 117).

(4) Automatic Control Technology (p. 117).

(5) Specific Data on Factors that Influence Fuel Economy of Existing Cars 
(p. 117).

(6) Improved Power-to-Weight Ratios, as well as Interior Volume-to-Weight Ratio

(7) Instrumentation to Provide Driver with Rea l-T ime Data on Fuel Efficiency

(8) Improved Traffic Control

(9) New Motors

(10) Improved Aerodynamic Design for Cars and Trucks

(11) New Primary Energy Sources (liquid, electric) (p. 117)

(12) Improved Intermodel Transfer Technology (p. 117)

(13) Technology for Improved Energy Efficiency in Air Transport. (p. 117)

(14) Applied Engine Combustion Research (p. 185, Report of the Demand and Conservati on Panel)

(15) Electric Vehicles, including R\&D on Batteries, Fuel Cells, Controls, Electrical Supply Structures, and New Engi nes for Autos and Trucks (p. 185)

(16) Aircraft Engines with Higher Efficiencies and Lower Emissions (p. 185)

(17) Lighter Weight Materials/Structures Using Composite and Non-Ferrous Materials, Improved Structural Designs, etc. (p.185)

(18) Alternative Energy Sources (synthetic fuels from coal and biomass, hydrogen, fuel cells, etc. (p. 185)

(19) Basic Res earch on Combustion, Materials for El ectrochemical Processes, and Systems. (p. 185)

\section{Transportation References}

Abel son, Philip H., and Allen L. Harmond. 1977. The Electronics Revolution. Science $195: 1085$.

Altendorf, J. P., and A. Kalberlah. 1976. A Comparison Between the Primary Ener gy Consumpti on of Electric and Gasoli ne Powered Vehicles. Paper presented at Fourth International Electric Vehicles Symposium, Dusseldorf, Germany, August 31-September 2.

American Public Transit Association. 1976. Transit Fact Book. Washington, D. C.: American Public Transit Association.

Ayres, R., R. M. Doggett, et al. 1975. Automobile Forecasting Models. Prepared for the Office of Technology Assessment, United States Congress. Draft, International Research and Technology, McLean, Va., September.

Ayres, R., et al. 1976. Automobile Forecasting Models. Draft Working Paper. 
MCL ean, Va.: Internati onal Res earch and Technology (IRT-446-12).

Bernard, Martin J. III, and Joseph L. Shofer. 1975. Policy Search Model for Evaluating Future Nati onal Transportati on Strategies Under Ener gy and Environmental Constraints. Paper presented at the Third Intersociety Conference on Transporation. Technical Sessi on on Resource/E ner gy Strategies, Atlanta, July 16.

Boeing Commercial Airplane Co. 1975. Intercity Passenger Transportation Data. Vol. 1: Service and Economic Comparisons; Vol. 2: Ener gy Comparisons.

Carley, William. 1976. Nation's Airlines Face Key Problem. Wall Street Journal. October 22.

Civil Aviation Advisory Group. 1976. Air Transportation: Comparative Assessment of Its Public Benefits.

Coon, C. W., et al. 1974. Technological Improvements to Automobile Fuel Consumpti on. Prepared for the U. S. Envi rormental Protection Agency and the U. S. Department of Transportation. San Antonio, Tex.: Southwest Research Institute.

DeLeuw Cather and Co. 1975. Case Studies of Transit Energy and Air Pollution Impacts. Prepared for the U. S. Envi romental Protecti on Agency. Washington, D. C.: DeLeuw Cather and Co. (68-01-2475).

Dickerson, Stephen L., and Raymond E. Goodson. 1975. A Low Cost/High Performance Resolution of the Urban Transportation Problems of Congestion, Energy, and Pollution. Paper presented at the Third Inter-society Conference on Transportation, At lanta, July 14-18.

Difiglio, Carmen, and Damain Kulash. 1976. Marketing and Mobility. Marketing and Mobility Pane 1, Interagency Task Force on Motor Vehicle Goals Beyond 1980, U.S. Department of Transportation, Washington, D.C.

Drake, John W. 1974. Social, Political, and Economic Constraints on Airline Fuel Optimization. Transportation Research $8(4 / 5)$.

Eltinge, Lamont. 1973. 1970's Development of 21st Century Mobile-Dispersed Power. Portland, Ore.: Society of Automotive Engi neers.

Friedman, K. M. 1977. Telecommunications and Transportation Energy Demand: Opportunity and Caveats. Ener gy Communications 3(6):555-600.

Goodson, R. E. 1976. Energy Utilization by Various Modes of Transportation. Address to the Automobile and Manufacturing Meeting, Society of Automotive Engineers, Detroit, October 15. In Energy and Transportation. Warrenda le, Pa.: Soc iety of Automotive Engineers (SP-406).

- 1977a. Conservation and Transportation: The Primary Issues. Paper presented at Joint Resources for the Future/Electric Power Res earch Institute Workshop on International Energy Consumption, Washington, D. C., September 1516 .

- 1977b. Federal Regulation of Motor Vehicles: A Summary and 
Analysis. Institute for Interdisciplinary Engi neering Studies, Purdue University. Washington, D. C.: U. S. Department of Transportation (2305867 ).

- 1977c. A Statement on the Potential for Transportation Energy Conservation. Prepared for the Hearings of the Subcommittee on Energy Conservation and Regulation, Committee on Interior and Insular Affairs, U.S. Senate, April 4.

, et a 1. 1977. Opportunity and Risks Assessment for Electric and Hybrid Vehicles. Institute for Interdisciplinary Engi neering Studies, Purdue Unversity. Washington, D. C.: U. S. Department of Transportation.

Goodson, R. E., K. M. Friedman, et al. Transportation Energy Conservati on $/$ Demand Opti ons to 2010. Purdue University. Prepared for the Demand and Conservation Panel, Committee on Nuclear and Alternative Energy Systems, Nati onal Res earch Council, Washingt on, D. C.

Hagey, Graham, and William Hamilton. 1976. The Future of Electric Land Transportation in the United States. Warrendale, Pa.: Society of Automotive Engineers (760118).

Harkness, Richard C. 1976. Technology Assessment of Telecommunications/ Transportati on Interaction, Vol. 1: Introducti on, Scenario, Development, and Policy Analysis. Draft, Stanford Research Institute. Prepared for the Office of Exploratory Res earch and Problem Assessment, National Science Found ation, September.

Harvey, D. G., and W. R. Menchen. 1975. A Technology Assessment of the Transition to Advanced Automotive Propulsion Systems. Columbia, Md.: Hittman Associates (H1 T-541).

Hirst, E. 1974a. Direct and Indirect Energy Requirements for Automobiles. Oak Ridge, Tenn.: Oak Ridge Nati ona 1 Laboratory (ORNL-NSF-EP-64).

- 1974b. Direct and Indirect Energy Use for Commercial Aviation. Transportation Res earch $8(4 / 5)$.

Hittman Associates. 1974. The Automobile, Energy, and the Environment. Columbia, Md.: Hittman Associates.

Hurter, D. A., and W. D. Lee. 1975. A Study of Technogical Improvements to Optimize Truck Configurations for Fuel Economy. Arthur D. Little. Springfield, Va.: National Technical Information Service (PB-238693).

Jet Propulsi on Laboratory. 1975. Should We Have a New Engine? An Automobile Power Systems Evaluation: Technical Report, Vol.2. Pasadena: Cal ifornia Institute of Technology.

Kendal1, E. T. 1975. Fuel Economy/Emission Tradeoff Study. Working Paper, Transporati on Systems Center. Cambridge, Mass.: U. S. Department of Trans portation (409-75-01).

Lathy, Charles E. 1975. Telecommunications Substitutability for Travel: An Ener gy Conservati on Potential. Office of Telecommunications. Washington, D. C.: U. S. Department of Commerce. 
MITRE. 1974. Energy and Envi romental Aspects of U. S. Transportation. In Energy Primer. Transportation Systems Center. Cambridge, Mass.: U. S. Department of Transportation.

Motor Vehicle Manufacturers Association. 1976. Motor Vehicle Facts and Figures '76. Detroit: Motor Vehicle Manuf acturers Association.

National Academy of Engineering. 1969. Telecommunications for Enhanced Metropolitan Function and Form. Committee on Telecommunications. Prepared for the Director of Telecommunications Management, Office of Emergency Preparedness, Executive Office of the President. Washington, D. C.: Nati onal Academy of Engineering.

National Aeronautics and Space Administration. 1975. Aircraft Fuel Conservati on Technology. Washington, D. C.: Nati onal Aeronautics and Space Administration.

National Research Council. 1974. The Rel ationship of Emissions to Ambient Air Quality. Vol. 3 of Air Quality and Auto Emissions Control. Coordinating Committee on Air Quality Studies, National Academy of Sciences-National Ac ademy of Engi neering. Prepared for the Committee on Public Works, U. S. Senate. 93rd Cong., 2d sess. Washington, D. C.: U. S. Government Printing Office $(93-24)$, p. 8 .

National Research Council. 1976. Criteria for Energy Storage R\&D. Committee on Advanced Ener gy Storage Systems, Ener gy Engi neering Board, Assembly of Engineering. Washington, D. C.: National Academy of Sciences.

Nilles, Jack M., R. Roy Carlson, Jr., Paul Gray, and Gerhard Hanneman. 1976. Tel ecommun ications-Transportation Tradeoffs: Options for Tomorrow.

New York: Wiley-Interscience.

Office of Technology Assessment, U. S. Congress. 1975. Energy, the Economy, and Mass Transit. Springfield, Va.: National Technical Information Service (PB-250624).

Piasetzki, J. 1976. On the Substitutability of Communications for Transportation: A Selectively Annot ated Bibliography. Council for Planning Librarians Exchange Bibliographics. Monticel10, I11.: Council of Planning Librarians (1099).

Pikarsky, Milton, and Daphne Christensen. 1976. Urban Transportation Policy and Management. Lexington, Mass.: D. C. Heath.

Pilati, David. 1974a. Airline Energy Use and Conservation Strategies. Oak Ridge, Tenn.: Oak Ridge Nati onal Laboratorv (ORNL-NSF -EP-69).

- 1974b. Energy Use and Conservation Alternatives for Airplanes. Transportation Research 8(4/5):433-41.

Pollard, J., D. Hiatt, D. Rubin. 1975. A Summary of Opportunities to Conserve Transportati on Energy. Transportati on Systems Center. Cambridge, Mass.: U. S. Department of Transportation (DOT-TSC-OST-75-22).

Povinelli, F.P., J.M. Klineberg, and J. J. Kramer. 1976. Toward a National 
Objective: Improving Aircraft Efficiency. Astronautics and Aeronautics 14 (February): 18-31.

Real Estate Research Corporation. 1974. The Costs of Sprawl. Prepared for Council on Envi romental Quality, U. S. Department of Housing and Urban Development, and U. S. Environmental Protection Agency. Washington, D. C.: U. S. Goverment Printing Office (041-011-0022).

Sheridan, David C., John J. Bush, and William R. Kuziak. 1976. A Study of the Ener gy Utilizati on of Gasoline and Battery-Electric Powered Special Purpose Vehicles. Warrendale, Pa.: Society of Automotive Engineers (760119).

Staley, J. L. 1979. A Transportati on Ener gy Use Forecasting Mode 1: An Integrated Model Approach. New York: Garland Publishing.

Steiner, John E. 1976. Future Technology in Commercial Airplanes. Paper presented to the American Society of Civil Engineers, Philadelphia, September 30.

Strobotne, R. L. 1974. Evolution and Effects of Energy Conservation in the Transportati on Sector. Paper presented at annual meeting of American Association for the Advancement of Science, San Francisco.

Stuntze, Mayo S., Jr., and Eric Hirst. Energy Conservation Potential of Urban Mass Transit. Federal Energy Administration Conservation Paper No. 34. Springfield, Va.: Nati onal Technical Inf ormation Service (PB-245 $336 / 9 \mathrm{BA})$.

Transportation Association of America. 1976. Transportation Facts and Trends. Washington, D. C.: Transportation Association of America.

U. S. Department of Commerce. 1975. Statistical Abstract of the United States. Bureau of Census. And earlier editions. Washingt on, D. C.: U. S. Government Printing Office.

U. S. Department of Transportation. 1974a. Highway Travel Forecasts. Office of Highway Planning, Federal Highway Administration. Springfield, Va.: National Technical Information Service (PB-239169).

- n.d. Automobile Standards for 1981-84. Rule-making support paper, National Highway Traffic Saf ety Adninistration. Washington, D. C.: U. S. Goverment Printing Office.

1974b. Potential for Motor Vehicle Fuel Economy Improvement. With the U. S. Envi romental P rotecti on Agency, joint report to Cangress. Washington, D. C.: U.S. Department of Transportation.

- 1974c. A Report for Ener gy Conservation Through Public Mass Transportation Improvements. Washington, D. C.: U. S. Department of Transport ation.

- 1975a. Climatic Impact Assessment Program Report. Springfield, Va.: National Technical Service.

- 1975b. Potential for Motor Vehicle Fuel Economy Improvement. Report No. 7: Truck and Bus Panel. With the U. S. Envi rormental Protection Agency. Washington, D. C.: U.S. Department of Transportation. 
1976a. Aviati on Forecasts: Fiscal Years 1977-1978. Federal

Aviation Administration. Washington, D. C.: U. S. Department of

Transportation.

- 1976b. Commercial Vehicle Post-1980 Goals Study. Inter-agency Task

Force. Washington, D. C.: U.S. Department of Transportation.

- 1976c. Energy Impact Analys is Resource Information. Federal Highway

Administration. Washington, D. C.: U. S. Department of Transportation.

- 1976d. Energy Statistics. Transportation Systems Center.

Cambridge, Mass.: U. S. Department of Transportation (DOT-TSC-OST-76-30).

- 1976e. Motor Vehicle Goals Beyond 1980. Air Quality Panel,

Interagency Task Force. Washington, D.C.: U.S. Department of

Transportation.

- 1976f. Motor Vehicle Goals Beyand 1980. Main Vol., Executive

Summary, and Panel Report. Washington, D. C.: U. S. Department of

Trans portation.

- $1976 \mathrm{~g}$. Motor Vehicle Goals Beyond 1980. Draft, Vols. 1 and 2.

Washington, D. C.: U. S. Department of Transportation, September 2.

- 1976h. National Transportation Trends and Choices to the Year 2000.

Draft, Washington, D. C., June 1 .

- 1976i. Proposed Programs for Aviation Energy Savings. Federal

Aviati on Administration. Report to the Congress. Washington, D. C.: U. S. Department of Transportation.

- 1976j. Summary of National Transportation Statistics.

Transportati on Systems Center. Washington, D. C.: U. S. Goverment Printing Office.

1977. National Transportation Trends and Choices: To the Year

2000. Washington, D. C.: U. S. Goverment Printing Office (050-000-00124-5).

U. S. House of Representatives. 1975. Electr ic Vehicle Research, Devel opment, and Demonstrati on Act of 1975. Hearings before the Subcommittee on Energy Research, Development, and Demonstration, Committee on Science and Technology, June 3-6. Washington, D. C.: U. S. Goverment Printing Office $(94-27)$.

U. S. Senate. 1975. Electr ic Vehicle Research, Devel opment, and Demonstration Act of 1975. Hearings before the Special Subcommittee on Science, Technology, and Commerce, Committee on Commerce, October 7 and 10. Washington, D. C.: U. S. Goverment Printing Office (94-96).

Urban Systems Research and Engineering. 1976. Baseline Energy Forecasts and Analysis of Alternative Strategies for Airline Fuel Conservation. Federal Energy Administration Conservation Paper No. 48. Springfield, Va.: National Technical Information Service (PB-255 351/9BA).

Watkins, Robert, and G. Scott Rutherford. 1975. A Survey of Urban

Transportation Control Strategies for Reducing Energy Consumption. Paper 
presented at the Third Intersociety Conference on Transportation, Atlanta, July $14-18$.

Wilchom, S., B. Burright, J. Enns, and T. Kirkwood. 1975. How to Save Gasoline: Public Policy Alternatives for the Automobile. Prepared for the National Science Foundation. Santa Monica, Cal.: Rand (R-1560-NSF).

Industry

(1) Materials Properties at High Temperature (p. 117).

(2) Characteristics of Industrial Combustion (p. 117).

(3) Heat Transfer and Recovery Methods (p. 117).

(4) Automatic Control Technology (p. 117).

(5) Improved Methods for Energy Monitoring and Housekeeping (p. 117).

(6) Improved Methods for Scrubbing Combustion Gases (p. 117).

(7) Process Retrofit Technologies (p. 117).

(8) Improved Combustion of Marginal Fuels (p. 117).

(9) Cogeneration of Heat and Electricity (p. 117).

(10) Automatic Monitoring of Energy Performance (p. 117).

(11) Low-Temperature Heat Utilization (p. 117).

(12) Basic New Processes that Reduce Overall Requirements for Energy and Other Resources (e.g. recycling, durability) per unit output.

(13) Modification of Material Properties to Enable Replacement of EnergyIntensive Materials with Less Energy-Intensive Material in Specific Applicati ons.

\section{Industrial References}

Ayers, R. U., and M. Narkus-Kramer. 1976. An Assessment of Methodologies for Estimating National Energy Efficiency. Arlington, Va.: International Res earch and Technology Corporation.

Barnes, R. W. 1976. The Potential Industrial Market for Process Heat from Nucl ear Reactors. Dow Chemical Co. Oak Ridge, Tenn.: Oak Ridge National Laboratory (ORNL /TM-5516).

Battel le Columbus Laboratories. 1975. Potential for Energy Conservation in the Steel Industry. Prepared for the Federal Ener gy Administration. Columbus, Ohio: Battel le Columbus Laboratories.

Board of Governors, Federal Reserve System. 1977. Industrial Production: 1976 Revisions. Washington, D. C.: Board of Governors, Federal Reserve System. 
Booz-Allen and Hamilton. 1975. Energy Consumption in the Food System. Bethesda, Md.: Booz-Allen and Hamilton.

General Motors. 1977. Industrial Energy Conservation: 101 Ideas at Work. Energy Management Section. Detroit: General Motors.

Gordian Associates. 1975. The Potential for Energy Conservation in Nine Selected Industries. 9 vols. Prepared for the Federal Energy

Administration. Washington, D.C.: Gordian Associates.

Hal 1, E. H., W. J. Hanna, L. D. Reed, J. Varga, Jr., D. N. Willians, K. E. Wilkes, B. E. Johns on, W. J. Mueller, E. J. Bradbury, and W. J. Frederick. 1975. Evaluation of the Potential for Energy Conservation in Seven Basic Industries. Battelle Columbus Laboratories. Springfield, Va.: Nati onal Technical Information Service (PB-244772).

Industry Week. 1977. New Rate Plan to Hike Industry Electric Bills. September 12, p. 135 .

Institute for Energy Analysis. 1976. Economic and Environmental Implications of a U. S. Nucl ear Moratorium 1985-2010. Prepared for the U. S. Nucl ear Regul atory Comm ission. Oak Ridge, Tenn.: Inst itute for Energy Analys is (ORAU/IEA-76-4).

Nydick, S. E., J. P. Davis, J. Dunlay, S. Fain, and R. Sukhuja. 1976. Study of In-Plant Power Generation in the Petroleum, Chemical and Paper Industries. Thermo Electron. Springfield, Va.: National Technical Information Service (PB-255659).

Resource Planning Associates. 1977. The Potential for Cogeneration Development in the Chemical Industry by 1985 . Inter im report to the Federal Energy Adninistration. Cambridge, Mass.: Resource Planning Associates, June.

Spencer, R. S., et al. 1975. Energy Industrial Center Study. Prepared for the Nati onal Science Foundation. Midland, Mich.: Dow Chemical Co.

Starr, C. 1975. A Strategy for National Electricity Production. Paper presented at the National Res earch Council Ener gy Engi neering Board Summer Session, Woods Hole, Mass.: July-August.

U. S. Department of Commerce. 1975a. Historical Statistics of the United States: Colonial Times to 1970. Bureau of Census. Washington, D. C.: U. S. Goverment Printing Office (003-024-00120-9).

- 1975b. Statistical Abstract of the United States: 1975. Bureau of the Census. Washington, D. C.: U. S. Goverment Printing Office $(0324-01050-0)$.

von Hippel, F., and R. Williams. 1976. Energy Waste and Nuclear Power Growth. Draft, Center for Envi rormental Studies. Princet on University Princeton, N. J. August.

Williams, R. H. 1978. Industrial Cogeneration. Center for Environmental Studies, Report No. 66. Princet on, N. J.: Princet on University.

V. Critical Summary 
Quite apart from its well-publicized difficulties as a major energy study, the CONAES Study represents a very weak R\&D needs study. It falls into the frequent trap of simply presenting a "laundry list" of research needs, many of which appear quite reasonable, with almost no justification or explanation of why the research is needed. The research needs are presented as if it is perfectly obvious that they are necessary from both a technical and an energy conservation standpoint. While they may have been obvious to the CONAES Panel, many persons are likely to want more justification than the opinion of the authors of the study before they accept the R\&D needs. Thus, the CONAES Report represents at best a "tickle list" of ideas for consideration in an R\&D Needs study. To do a complete job, one would have to exami ne the energy flows addressed by the research, identify specific technical barriers, survey the extent to which the research is being covered in existing programs, and

prioritize R\&D needs according to the ir appropriateness for federal funding. $\mathrm{Cl}$ early, the CONAES work represents only a small step toward completion of a full-blown R\&D needs identification effort.

\section{Comments}

To glean all of the R\&D needs in CONAES, one must consult the Report of the Demand and Conservati on Panel (a separate document), as well as the main report. The main report is an incomplete summary of the other reports.

Reviewed by WJH. 
.

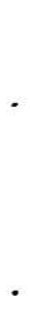

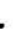


- Report No. 13

I. Cremers, C. J. "Environmental and Conservation Research Needs in the Eighties", American Society of Mechanical Engineers Publication 76-WA/ RGPC-2. American Society of Mechanical Engineers, New York, 1976.

Summary of contribution by the Research and Goals Committee of ASME.

II . Technical and/or End-Use Focus

Research opportunities focus on environmental and conservation research addressable by mechanical engineers. Conservation is broken down into energy and materials.

\section{Types of Information Provided}

1. No energy use data were reviewed.

2. No energy savings data were given.

3. No estimate of time to commercialization.

4. No review of existing research.

5. No methodology presented.

IV. R\&D Opportunities

(1) Waste heat utilization (from power generation plants) assessments of the previous and existing state of the art need to be made before an assessment ${ }^{+}$most likely directions for R\&D can be made.

(2) Heat Exchangers (single-phase $\mathrm{HX}$, oil coolers, evaporators, and condensers). - There is insufficient knowledge of details of flow and tranfer mechanisms, as well as the effects of manufacturing tolerances and geometric perturbations on the performance of the heat exchanger, the role of contaminants, and the effect of fouling.

(3) Internal combustion engines - Alternative engine cycles, more efficient carburation of fuel injection, computer control, stratified charges and higher operating temperatures are all areas needing further R\&D. Better and more rapid means of heat exchange and regeneration in Stirling engines must be found.

(4) Industrial gas turbines - have not been exploited to the ir full potential.

- Design data are needed for advanced turbine and compressor configurations.

- High temperature materials needed to withstand higher. temperatures - research needed on composites, ceramics, and metals.

(5) Alternates to petroleum fuels - e.g. hydrogen from water by thermochemical means, methanol from coal, fuel cells.

(6) Heat Pump Systems - lack of information on seasonal operation. 
Need modeling of system and load to determine economics of operation.

(7) Furnace Systems - frequently have low efficiencies. Suggest studies of furnace operation, draft control, heat exchange design and controls.

(8) Waste heat recovery from buildings - computer modeling of systems and control strategies.

(9) Insulating materials - cheaper and more efficient. Insulative panels for inside mounting in retrofit applications where between the walls insulation may not be attractive.

v. Critical Summary

A laundry 1 ist of R\&D opportunities. Apparently accurate technically, but not well justified. No references.

VI. Comments

Useful as a shopping list to be investigated in the process of determining ECUT R\&D needs.

Reviewed by WEG. 
- Report No. 14

I. Department of Energy. Department of Energy Program Objectives, Fluid Waste Heat Recovery and Utilization. TID-28393. Department of Energy, Washington, D.C., February 1978.

II. Technical and/or End-Use Focus

This report discussed fluid waste heat recovery in both the industrial and residential/commercial end use sectors, with the emphasis on the former.

III. Types of Information Provided

1. No review of energy end-use data was made.

2. Conservation potential for may of the suggestions was included.

3. Expected development times were usually included.

4. Projects undertaken as the result of a workshop in 1976 were described.

5. No methodology for ident ifying R\&D opportunities was given.

IV. R\&D Opportunities

See the review of the parent report, Workshop on Fluid Waste Heat Recovery and Utilization, November 17-19, 1976.

V. Critical Summary

This report is a response to action taken as a result of a workshop held in 1976.

This report is a companion to a more complete document (1976) which describes each conservation need. Both documents are the result of a workshop involving persons from industry and agriculture who gathered to recommend government sponsored development projects related to conserving energy by utilizing waste heat.

Though many suggestions were presented, all deal with short-term projects ranging from several months to a few years. The approach at identifying projects was very use specific and few suggestions with generic motivation were put forth. This feature allowed the workshop participants to quant ify the energy potential and expected effort for each project.

Since that workshop in 1976 several projects have been undertaken and the status of the projects are described here.

VI. Comments

Reviewed by $\mathrm{GJH}$ 

- Report No. 15

I. Department of Energy. Report of the Proceedings of the DOE Workshop on Energy Conservation in the Textile Industry. TIC-10007. Division of Industrial Energy Conservation, Department of Energy, January 24 and 25, 1978.

II. Technical and/or End-Use Focus

As implied by the title, this report focuses on the textile industry.

III. Types of Information Provided

1. No review of energy end-use data was made.

2. Potential savings were estimated for most of the projects proposed.

3. Approximate R\&D times were estimated for most of the project.

4. Programs funded by the conservation office were briefly reviewed.

5. The workshop participants were identified from various trade and professional contacts. They were then assembled in informal roundtable discussions to explore near-term needed research.

IV. R\&D Opportunities

See attached pages.

V. Critical Summary

The professional backgrounds of the workshop participants likely aided in a comprehensive survey of salient needs within the four subcategories:

1) textile energy management systems, 2) preparation and dyeing,

3) finishing, 4) textile yarn and fabric. The time frame of the research and development was very much in the near term, several months to a few years. The projects were therefore suggestions of incremental improvement rather than of major change.

Most of the projects recommended were specific to various textile processes. However, a few projects such as drying and cogeneration did have greater generic utility.

Due to the short nature of the workshop, energy use data wasn't we 11 researched. To estimate the energy savings the panelists were limited to a "best guess". A fair amount of uncertainty thus surrounds these values.

The attached tables list the projects suggested by the workshop participants and also provide a prioritization with in each working group. Even though this is a useful feature, the method used to assign the ratings wasn't explained in the report.

VI. Comments 
TEXTILE ENERGY MANAGEMENT SYSTEMS

\begin{tabular}{|c|c|c|c|c|c|c|}
\hline Project & Priority & $\begin{array}{l}\text { Estimated } \\
\text { Energy } \\
\text { Conserved }\end{array}$ & $\begin{array}{l}\text { 'Time } \\
\text { Frame }\end{array}$ & Cost & $\begin{array}{l}\text { Eederal } \\
\text { Role }\end{array}$ & Reference \\
\hline $\begin{array}{l}\text { Heat Recovery of } \\
\text { Contaninated } \\
\text { Exhausts }\end{array}$ & $H \doteq g h$ & $\begin{array}{l}25 \% \text { of drver } \\
\text { energy } \\
\text { consumption }\end{array}$ & $\begin{array}{ll}R-2 & \text { Yrs } \\
D-1 & \text { Yr } \\
D-1 & \text { Yr }\end{array}$ & & $\begin{array}{l}R-1.00 \% \\
D-75 \% \\
D-50 \%\end{array}$ & $\begin{array}{r}\text { Page } \\
37\end{array}$ \\
\hline $\begin{array}{l}\text { Energy Analysis of } \\
\text { Textile Processes }\end{array}$ & IIigh & & $R-3$ to 5 YCS & $\mathrm{R}-9$ man yrs & $\mathrm{R}-100 \%$ & 38 \\
\hline $\begin{array}{l}\text { Development of } \\
\text { Coal Boiler }\end{array}$ & High & 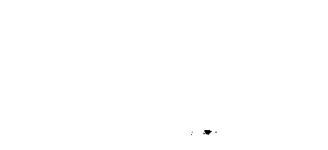 & $\begin{array}{ll}R-1 & \text { Yr } \\
D-2 & \text { Yrs } \\
D-2 & \text { Yrs }\end{array}$ & $\begin{array}{l}\mathrm{R}-2 \text { man yrs } \\
\mathrm{D}-20 \text { man } \mathrm{yrs} \\
\mathrm{D}-\$ 3.5 \mathrm{MM}\end{array}$ & $\begin{array}{l}R-100 \% \\
D-100 \% \\
D-75 \%\end{array}$ & 38 \\
\hline $\begin{array}{l}\text { Improvement of } \\
\text { Drying Technology }\end{array}$ & Iigh & $\begin{array}{l}20 \% \text { of } \\
\text { drying } \\
\text { energy }\end{array}$ & $\begin{array}{ll}R-1 & Y r \\
D-2 & Y r s \\
D-1 & Y r\end{array}$ & $\begin{array}{l}\text { R-4 man yrs } \\
D-\$ 250 \mathrm{M} \\
D-\$ 150 \mathrm{M}\end{array}$ & $\begin{array}{l}\mathrm{R}-100 \% \\
\mathrm{D}-75 \% \\
\mathrm{D}-75 \%\end{array}$ & 39 \\
\hline
\end{tabular}

PREPARATION AND DYEING

\begin{tabular}{|c|c|c|c|c|c|c|}
\hline Project & Priority & $\begin{array}{l}\text { Estimated } \\
\text { Energy } \\
\text { Conserved }\end{array}$ & $\begin{array}{l}\text { Time } \\
\text { Erame }\end{array}$ & Cost & $\begin{array}{l}\text { Federal } \\
\text { Role }\end{array}$ & Reference \\
\hline Moisture Mnalyzer & 1. & .0025 quad & $\begin{array}{ll}R-2 & \text { yrs } \\
D-1 & \text { Yr } \\
D-1 & \text { Yr }\end{array}$ & $\begin{array}{l}R-\$ 180 \mathrm{M} \\
\mathrm{D}-\$ 90 \mathrm{M} \\
\mathrm{D}-\$ 90 \mathrm{M}\end{array}$ & $\begin{array}{l}R-85 \% \\
D-85 \% \\
D-\quad 0 \%\end{array}$ & 43 \\
\hline
\end{tabular}

\section{Project Overview Matrix}




\begin{tabular}{|c|c|c|c|c|c|c|}
\hline Project & Priority & $\begin{array}{l}\text { Estimated } \\
\text { Energy } \\
\text { Conserved }\end{array}$ & $\begin{array}{l}\text { Time } \\
\text { Frame }\end{array}$ & $\cos t$ & $\begin{array}{l}\text { Federal } \\
\text { Role }\end{array}$ & Reference \\
\hline $\begin{array}{l}\text { Exhaust Gas } \\
\text { Incineration }\end{array}$ & 2 & $\begin{array}{l}1.1 \times 10^{13} \\
\text { Btu's }\end{array}$ & $R-1 \quad y x$ & $\mathrm{R}-\$ 250 \mathrm{M}$ & $\begin{array}{l}R-100 \% \\
D-100 \% \\
D-20 \%\end{array}$ & 43 \\
\hline $\begin{array}{l}\text { Pad/Batch } \\
\text { Preparation and } \\
\text { Dyeing }\end{array}$ & 3 & .0033 Quads & $\begin{array}{ll}R-2 & \text { yrs } \\
D-2 & \text { Yrs } \\
D-1 & \text { yr }\end{array}$ & $\begin{array}{ll}R-\$ 250 & M \\
D-\$ 250 & M \\
D-\$ 500 & M\end{array}$ & $\begin{array}{l}R-80 \% \\
D-60 \% \\
D-50 \%\end{array}$ & 44 \\
\hline $\begin{array}{l}\text { Energy Optimization } \\
\text { in Textile Scouring }\end{array}$ & 4 & .0576 Quads & $\begin{array}{ll}R-2 & \text { yxs } \\
D-1 & y r \\
D-1 & y r\end{array}$ & $\begin{array}{l}\mathrm{R}-\$ 500 \\
\mathrm{D}-\$ 500 \mathrm{M} \\
\mathrm{D}-\$ 1 \quad \mathrm{MM}\end{array}$ & $\begin{array}{l}R-100 \% \\
D-80 \% \\
D-60 \%\end{array}$ & 44 \\
\hline $\begin{array}{l}\text { Energy Efficient } \\
\text { Moisture Removal } \\
\text { Systems }\end{array}$ & 5 & $\begin{array}{l}1.0-25 \% \text { of encrgy } \\
\text { consumed for } \\
\text { moisture removal }\end{array}$ & $\begin{array}{ll}R-2 & \text { yrs } \\
D-1 & \text { yr } \\
D-1 & \text { yr }\end{array}$ & 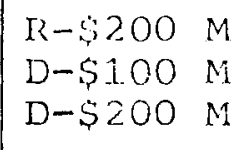 & $\begin{array}{l}R-100 \% \\
D-90 \% \\
D-50 \%\end{array}$ & 45 \\
\hline $\begin{array}{l}\text { Cleaning Exhaust } \\
\text { Emissions for } \\
\text { Heat Recovery }\end{array}$ & 6 & $\begin{array}{c}7.1 \times 10^{12} \\
\text { Btu's }\end{array}$ & $\begin{array}{ll}R-1 & Y r \\
D-1 & Y r \\
D-1 & Y r\end{array}$ & $\begin{array}{ll}R-\$ 50 & M \\
D-\$ 50 & M \\
D-\$ 200 & M\end{array}$ & $\begin{array}{l}R-1.00 \% \\
D-1.00 \% \\
D-50 \%\end{array}$ & 46 \\
\hline $\begin{array}{l}\text { Direct Application } \\
\text { of Process Chemicals }\end{array}$ & 7 & $\underset{B O E}{0.4 \times 10^{6}}$ & $\begin{array}{ll}R-4 & \text { yrs } \\
D-2 & \text { yrs } \\
D-1 . & \text { Yr }\end{array}$ & $\begin{array}{l}R-\$ 400 \\
D-\$ 200\end{array}$ & $\begin{array}{l}R-100 \% \\
D-80 \% \\
D-50 \%\end{array}$ & 46 \\
\hline $\begin{array}{l}\text { Low-Energy } \\
\text { Continuous Dye } \\
\text { Systems }\end{array}$ & 8 & .0268 Quads & $\begin{array}{ll}R-2 & \text { Yrs } \\
D-1 & \text { Yr } \\
D-1 & \text { Yx }\end{array}$ & $\begin{array}{l}R-\$ 500 \mathrm{M} \\
D-\$ 500 \mathrm{M} \\
\mathrm{D}-\$ 1 \mathrm{MM}\end{array}$ & $\begin{array}{l}R-30 \% \\
D-65 \% \\
D-50 \%\end{array}$ & 47 \\
\hline Sludge Incineration & 9 & $\begin{array}{c}\begin{array}{c}1.4 \times 10^{12} \\
\text { Btu's }\end{array} \\
\end{array}$ & $D-2$ yrs & & $\begin{array}{l}D-100 \% \\
D-20 \%\end{array}$ & 47 \\
\hline $\begin{array}{l}\text { Anerobic Digestion } \\
\text { of Sludge }\end{array}$ & 9 & $\begin{array}{l}\text { 1. } 5 \times 10^{12} \\
\text { Btu's }\end{array}$ & $D-2$ yrs & $D-\$ 500 \%$ & $\begin{array}{l}12-100 \% \\
D-1.00 \%\end{array}$ & 47 \\
\hline
\end{tabular}


'TEX'TILE YARN AND FABRIC

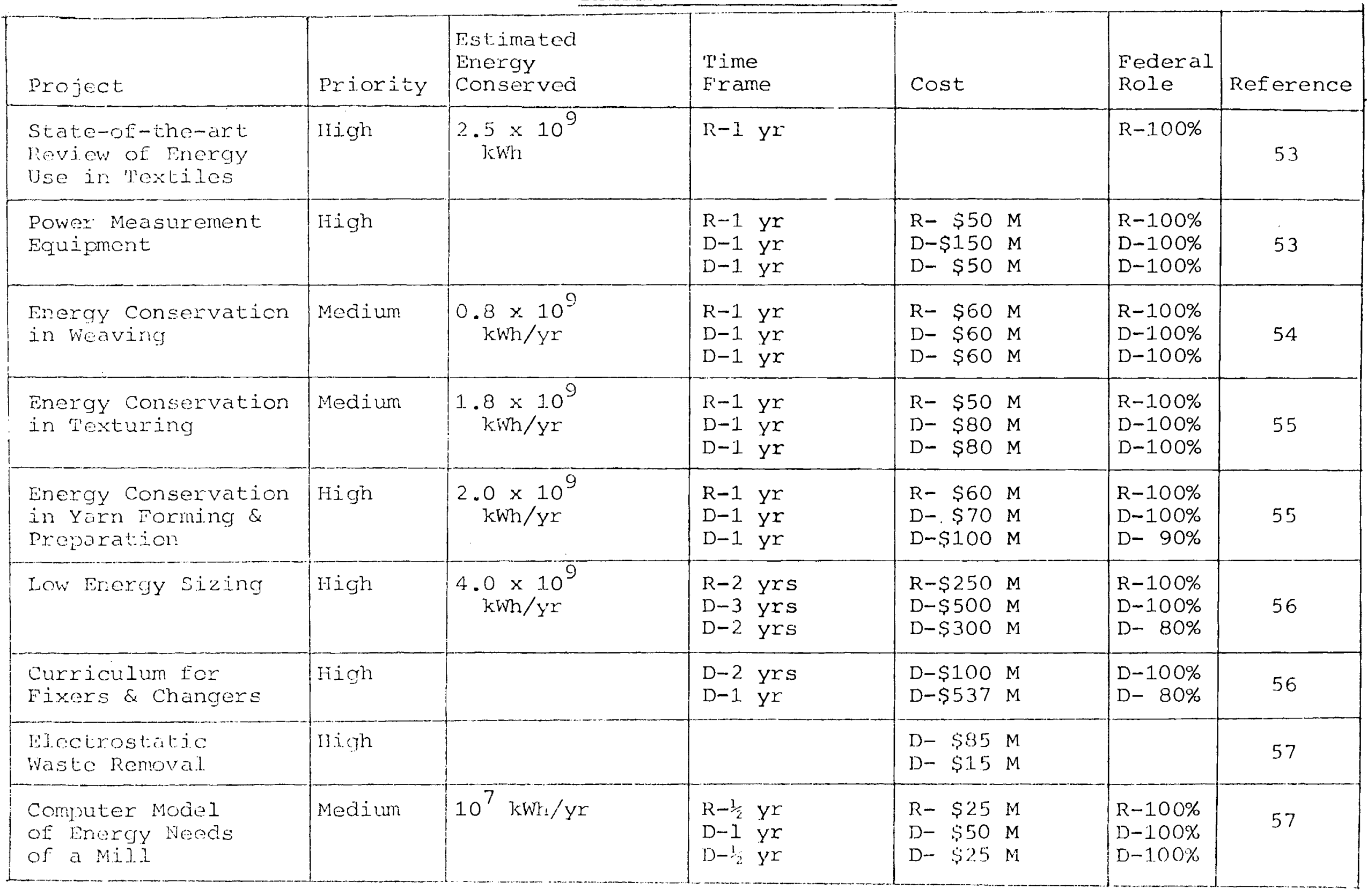




\begin{tabular}{|c|c|c|c|c|c|c|}
\hline Project & Priority & $\begin{array}{l}\text { Estimated } \\
\text { Energy } \\
\text { Conserved }\end{array}$ & $\begin{array}{l}\text { 'Time } \\
\text { Frame }\end{array}$ & $\cos t$ & $\begin{array}{l}\text { Eodoral } \\
\text { Role }\end{array}$ & Reference \\
\hline $\begin{array}{l}\text { Optimizing Power } \\
\text { Needs of Greige Mill }\end{array}$ & High & $\begin{array}{c}675 \times 10^{6} \\
\mathrm{kWh} / \mathrm{yr}\end{array}$ & $D-1 \quad y^{r}$ & $\mathrm{D}-\$ 250 \mathrm{M}$ & $D-75 \%$ & 57 \\
\hline $\begin{array}{l}\text { Energy Conservation } \\
\text { via Lubricants }\end{array}$ & Medium & $\begin{array}{l}5 \% \text { of textile } \\
\text { mill energy use }\end{array}$ & $\begin{array}{ll}R-1 & Y r \\
D-1 & Y r \\
D-1 & Y r\end{array}$ & $\begin{array}{l}R-\$ 50 \\
D-\$ 100 \\
D-\$ 50\end{array}$ & $\begin{array}{l}R-100 \% \\
D-100 \% \\
D-80 \%\end{array}$ & 58 \\
\hline $\begin{array}{l}\text { Tuft to Yarn } \\
\text { System }\end{array}$ & High & & $\begin{array}{ll}R-3 & \text { Yrs } \\
D-2 & \text { Yrs } \\
D-1 & \text { Yrs }\end{array}$ & & & 59 \\
\hline $\begin{array}{l}\text { Electrostatic } \\
\text { Spinning }\end{array}$ & Medium & $\begin{array}{l}30 \% \text { of energy } \\
\text { used by present } \\
\text { Equipment }\end{array}$ & $\begin{array}{ll}R-3 & \text { Yrs } \\
D-2 & \text { Yrs } \\
D-1 & y r\end{array}$ & & & 59 \\
\hline
\end{tabular}

\section{FINISHING}

\begin{tabular}{|c|c|c|c|c|c|c|}
\hline Project & Priority & $\begin{array}{l}\text { Estimated } \\
\text { Energy } \\
\text { Conserved }\end{array}$ & $\begin{array}{l}\text { Time } \\
\text { Frame }\end{array}$ & cost & $\begin{array}{l}\text { Federal } \\
\text { Role }\end{array}$ & Reference \\
\hline $\begin{array}{l}\text { Low Temperature } \\
\text { Curing }\end{array}$ & High & $\begin{array}{c}0.6 \times 10^{6} \\
B \cap E / Y r\end{array}$ & $\begin{array}{ll}R-2 & \text { Yrs } \\
D-1 & Y r \\
D-1 & Y r\end{array}$ & $\begin{array}{ll}R-\$ 320 & M \\
D-\$ 160 & M \\
D-\$ 100 & M\end{array}$ & $\begin{array}{l}R-75 \% \\
D-75 \% \\
D-50 \%\end{array}$ & 63 \\
\hline $\begin{array}{l}\text { Optimization of } \\
\text { Drying } \\
\text { Techniques }\end{array}$ & High & $\begin{array}{c}2.5 \times 10^{6} \\
B \cap \mathrm{B} / \mathrm{Yr}\end{array}$ & $\begin{array}{ll}R-1 & Y r \\
D-1 & Y r \\
\mathrm{D}-1 & Y r\end{array}$ & $\begin{array}{l}R-\$ 75 \mathrm{M} \\
D-\$ 75 \mathrm{M} \\
D-\$ 75 \mathrm{M}\end{array}$ & $\begin{array}{l}D-95 \% \\
D-95 \% \\
D-95 \%\end{array}$ & 63 \\
\hline $\begin{array}{l}\text { Metering Techniques } \\
\text { for Finishing } \\
\text { Agents }\end{array}$ & High & $\begin{array}{l}2.25 \times 10^{6} \\
\mathrm{BOE} / \mathrm{Yr}^{-}\end{array}$ & $\begin{array}{ll}\mathrm{R}-1 & \mathrm{Yr}^{\mathrm{r}} \\
\mathrm{D}-2 & \mathrm{Yrs}^{\mathrm{r}} \\
\mathrm{D}-1 & \mathrm{Yr}^{\mathrm{r}}\end{array}$ & $\begin{array}{l}R-\$ 80 \\
D-\$ 400\end{array}$ & $\begin{array}{l}R-75 \% \\
D-75 \% \\
D-50 \%\end{array}$ & 63 \\
\hline
\end{tabular}




\begin{tabular}{|c|c|c|c|c|c|c|}
\hline Project & Priority & $\begin{array}{l}\text { Estjmatea } \\
\text { Energy } \\
\text { Conserved }\end{array}$ & $\begin{array}{l}\text { 'I'ime } \\
\text { Frame }\end{array}$ & $\cos t$ & $\begin{array}{l}\text { Federal } \\
\text { Role }\end{array}$ & Reference \\
\hline $\begin{array}{l}\text { Exhaust } \\
\text { Incineration }\end{array}$ & High & $\begin{array}{l}\text { 1. } 2 \times 10^{6} \\
\mathrm{BOE} / \mathrm{Yr}\end{array}$ & $\begin{array}{ll}R-1 & \text { yr } \\
D-1 & \text { yr } \\
D-2 & \text { yrs }\end{array}$ & $\begin{array}{ll}\mathrm{R}-\$ 500 & \mathrm{M} \\
\mathrm{D}-\$ 500 & \mathrm{M} \\
\mathrm{D}-\$ 500 & \mathrm{M}\end{array}$ & $\begin{array}{l}R-100 \% \\
D-75 \% \\
D-50 \%\end{array}$ & 64 \\
\hline $\begin{array}{l}\text { Fifluent } \\
\text { Neutralization } \\
\text { Via Fluo cases }\end{array}$ & Mediun & $\begin{array}{l}0.4 \times 10^{6} \\
\operatorname{sOE} / y^{2}\end{array}$ & $\begin{array}{ll}R-2 & \text { yrs } \\
D-2 & \text { yrs } \\
D-2 & \text { yrs }\end{array}$ & $\begin{array}{ll}\mathrm{R}-\$ 500 & \mathrm{M} \\
\mathrm{D}-\$ 500 & \mathrm{M} \\
\mathrm{D}-\$ 1.5 & \mathrm{MM}\end{array}$ & $\begin{array}{l}R-100 \% \\
D-75 \% \\
D-50 \%\end{array}$ & 64 \\
\hline $\begin{array}{l}\text { New Size } \\
\text { Developmert }\end{array}$ & Medium & $\begin{array}{c}1200-1600 \\
\mathrm{Btu} / \mathrm{Lb}\end{array}$ & $\begin{array}{l}\mathrm{R}-3 \text { yrs } \\
\mathrm{D}-1 \text { to } 2 \text { yrs }\end{array}$ & & & 65 \\
\hline $\begin{array}{l}\text { Study of the } \\
\text { Machnozzle }\end{array}$ & Mediun & $\begin{array}{l}2.5 \times 10^{6} \\
130 \mathrm{H} / \mathrm{yr}\end{array}$ & $\begin{array}{ll}R-1 & \text { Yr } \\
D-1 & Y^{r} \\
D-1 & Y^{r}\end{array}$ & $\begin{array}{l}\mathrm{R}-\$ 50 \mathrm{M} \\
\mathrm{D}-\$ 25 \mathrm{M} \\
\mathrm{D}-\$ 25 \mathrm{M}\end{array}$ & $\begin{array}{l}R-1.00 \% \\
D-1.00 \% \\
D-50 \%\end{array}$ & 65 \\
\hline Radiation Curing & Medium & $\begin{array}{l}9 \times 10^{6} \\
\text { BOE/Yr }\end{array}$ & $\begin{array}{ll}R-2 & \text { yrs } \\
D-1 & \text { yr } \\
D-1 & \text { Yr }\end{array}$ & $\begin{array}{ll}R-\$ 170 & M \\
D-\$ 800 & M \\
D-\$ 800 & M\end{array}$ & $\begin{array}{l}R-80 \% \\
D-65 \% \\
D-55 \%\end{array}$ & 65 \\
\hline $\begin{array}{l}\text { Systems Analysis } \\
\text { of a pinishing } \\
\text { plant }\end{array}$ & Medium & & & $\mathrm{R}-\$ \$ 100 \mathrm{M}$ & & 66 \\
\hline $\begin{array}{l}\text { New Bleaching } \\
\text { Technology }\end{array}$ & Medium & $\begin{array}{l}0.46 \times 10^{6} \\
\text { BOE/yr }\end{array}$ & $\begin{array}{ll}R-1 & \text { yr } \\
D-1 & y r \\
D-1 & y r\end{array}$ & $\begin{array}{l}R-\$ 150 \\
D-\$ 100\end{array}$ & $\begin{array}{l}R-70 \% \\
D-60 \% \\
D-50 \%\end{array}$ & 66 \\
\hline $\begin{array}{l}\text { Altcrnate Tuels } \\
\text { for Finishing }\end{array}$ & Medium & & & & & 66 \\
\hline $\begin{array}{l}\text { Microwave or } \\
\text { Dielectric Heating }\end{array}$ & Low & & & & & 67 \\
\hline
\end{tabular}




\begin{tabular}{|l|l|l|l|l|l|}
\hline Project & Priority & $\begin{array}{l}\text { Estimated } \\
\text { Energy } \\
\text { Conserved }\end{array}$ & $\begin{array}{l}\text { Fime } \\
\text { Frame } \\
\text { Roleral }\end{array}$ & Reference \\
\hline $\begin{array}{l}\text { Modification of } \\
\text { Team Can }\end{array}$ & Low & & & 67 \\
\hline $\begin{array}{l}\text { Flame Curing } \\
\text { Finishes }\end{array}$ & $\begin{array}{l}\text { Very } \\
\text { Low }\end{array}$ & & & & \\
\hline
\end{tabular}




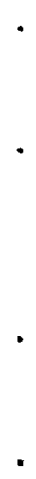


- $\quad$ Report No. 16

I. Department of Energy. Research Workshop on Energy Conservation Through Enhanced Heat Transfer. C00-4649-8. U.S. Department of Energy, October 1979.

II. Technical and/or End-Use Focus

The focus of the report is on heat transfer problems in the industrial end use sector.

III. Types of Information Provided

1. No review of energy end-use data was made.

2. No estimates of energy savings from research were made.

3. No estimates of times to commercialization were given.

4. Existing research programs sponsored by DOE in heat recovery and heat exchangers were reviewed. The four categories are: 1) performance and reliability penalties inflicted by heat exchanger environment, 2) efficient, economical high temperature heat recovery, 3) poor economics in recovery of low temperature waste heat, and 4) test and evaluation of improved heat exchangers.

5. No methodology for identifying R\&D opportunities was given.

IV. R\&D Opportunities

AIR CONDITIONING AND REFRIGERATION

(1) Augmented surfaces are needed to yield enhanced performance under dehumidifying, frosting, or icing conditions.

(2) Contact resistance in the use of augmented fin surfaces must be reduced.

(3) The maldistribution of fluid needs to be studied.

(4) Fouling factors must be better understood.

CHEMICAL AND PROCESS INDUSTRIES

(1) Fouling data must be improved.

HEAT RECOVERY

(1) Fouling of augmented surfaces must be understood.

(2) The aging effect of boiling needs to be understood.

(3) The influence of tube row, tube spacing, fin height, and upstream turbulence on tubes with low fins in cross flow must be understood.

(4) The performance of finned tubes with shroud shapes needs to be determined. 
(5) Heat exchangers with variable fin density.

(6) Augment tubes with thermoelectric el ements.

(7) Heat pipe exchanger evaluation.

(8) Finned plastic heat exchangers and plastic coated exchangers.

\section{Critical Summary}

This report is a good overview of a rrent government funded research programs in heat transfer and of further research opportunities as percieved by members of the technical field.

Due to the workshop format used to generate the report, the document isn't comprehensive, but many of the salient needs in heat transfer are described. The disaussion is predominately technical and many specific needs are included. Energy conservation potential was not included as a point of discussion.

As seen in Section four, many of the research suggestions are for basic $r$ ather than applied research.

In addition to the presentations from the work groups, the document al so included the question and answer periods following the presentations. The comments offered were often interesting supplements to the information provided by the work groups.

VI. Comments

Reviewed by GJH. 
- $\quad$ Report No. 17

I. Energy Research and Development Administration. Agricultural Processing Industry Workshop on Energy Conservation. CONF-760355. Division of Industrial Energy Conservation, Energy Research and Development Administration, Washington, D.C., March 4-5, 1976.

II. Technical and/or End-Use Focus

As implied by the title, the focus of this report was on the agricultural processing industry.

III. Types of Information Provided

1. No review of end-use data was made.

2. Savings were estimated for most of the projects recommended by the workshop participants.

3. Estimates for most projects were given along with estimates of funding.

4. No review of existing research programs was made.

5. No methodology for identifying R\&D opportunties was presented.

IV. R\&D Opportunities

See attached sheets.

V. Critical Summary

The focused topic of the workshop allowed the participants to be comprehensive with in these limits. The suggestions for research and development were applied to very specific needs in agricultural processing. These needs predominately involved short-term research efforts; hence, most projects included in the report were expected to bear fruit in several months to a few years.

To further spec ify the projects, anticipated levels of funding were also included. To further justify the projects, estimates of potential energy savings were often given; however, the sources of these estimates were usually not cited.

\section{Comments}

Reviewed by GJH 
ATTACHMENTS

\section{APPENDIX B - CHAIRMEN'S SUMMARY REMARKS}

Chemicals 23

Dairy 25

Fruits and Vegetables 29

Grain 33

Meats 37

Textiles 41

APPENDIX C - RECOMMENDED PROJECTS

Chemicals

1. Alternate sources of feed stocks for ammonia plants to replace natural gas with coal

2. Conservation of energy during production of phosphoric acid

3. Use of coal as a fuel for ammonia plants instead of natural gas

4. Study total energy consumption uf marketing systems for anhydrous ammonia versus nitrogen solution

5. Conservation of energy in granulation plants

6. Improve heat recovery in existing ammonia plants

7. Conserve energy in phosphate rock mining by extracting $\mathrm{P}_{2} \mathrm{O}_{5}$ directly from rockclay matrix

8. Combine the operations of an anhydrous ammonia plant and a steel blast furnace

9. Conservation of energy through minimum tillage

10. Improve efficiencies of pollution control equipment in fertilizer plants

11. Conservation of electrical power in granulation plants 


\section{APPENDIX - C - RECOMMENDED PROJECTS}

Chemicals (continued)

12. Efficient marketing and distribution of fertilizers and agricultural chemicals

13. Use of byproducts in agriculture

14. Solar evaporation of potash brines to concentrate and crystallize potash

15. Wet grinding of phosphate rock

$\underline{\text { Dairy }}$

16. Development and dissemination of technical educational materials and technology transfer

17. Development of alternatives to current package sealing techniques

18. Integrated energy systems for dried food products

19. Utilization of heat pumps in current manufacturing processes

20. Utilization of solid wastes as an energy source

21. Development of a 2:1 sterile concentrate milk beverage

22. Identification and evaluations of constraints on energy utilized by the dairy products industry

23. Improvement of energy efficiency of inplant clean-up practices

24. Phase I: Feasibility study of sterile fluid milk as a major conservation measure; Phase II: Development and demonstration of a pilot system

Fruits and Vegetables

25. Heat recovery - gases and water 


\section{APPENDIX C - RECOMMENDED PROJECTS}

Fruits and Vegetables (continued)

26. Methane production and anaerobic digestion of wastes

27. Improved steam traps

28. "Good management"

29. Systems studies of industrial parks

30. Fuel substitution

31. Improved combustion efficiency

32. Improved refrigeration equipment and processes

33. Bulk reduction to decrease handling, warehousing and transportation costs

34. Earth covered and/or underground storage of cold and/or frozen products

35. Packaging

36. Water removal

37. Sterilization

38. Equipment ratings

39. Evaluation of current practices in food processing firms

40. Education of the public

Grain

41. Improved heat transfer and heat recovery capability of drying systems

42. Improved technology for process and moisture control

43. Iiquid concentration

44. Improved heat recovery systems 
APPENDIX C - RECOMMENDED PROJECTS

Grain (continued)

45. Alternate fuels to replace natural gas

46. Alternate processing and formulation methods to reduce energy consumption

47. Improved equipment design

Meats

48. Systems analysis of energy use in the meat industry

49. Automatic air/fuel ratio control for small boilers

50. Recycle waste water effluents through reclamation system to produce crystal clear potable water certifiable by U.S. Health Dept. laboratories

51. Re-use of hot and/or tempered water through filtration

52. Reduce energy used in beef and hog viscera inspection tables

53. Reduce energy used in high pressure and high temperature water beef carcass washer

54. Substitution of sanitation for refrigeration energy to reduce energy used in chilling red meats

55. Elimination of after-burners

56. Investigate use of outside winter air for refrigeration in northern plants

57. Recovery of lost heat escaping plant in waste effluent

58. Reduce natural gas consumption in hog singeing operation

59. Develop means of eliminating condensation on plant ceiling that is less energy intensive than current procedure 


\section{APPENDIX C - RECOMMENDED PROJECTS}

Meats (continued)

60. Hot deboning

61. Industrial boiler system

62. Minimize packaging material for meats

63. Development of alternate methods for chilling carcasses

64. Develop alternate method of removing water from material to be rendered inedible

65. Better ammonia and freon refrigeration systems and controls for defrosting

66. Raise low pressure steam to 100 psig level by compression cycle

67. Elimination of steam traps with introduction of a sump at lower physical level and pumping of condensate under pressure to steam generator

68. Improving scalding and de-hairing methods for hogs, on-line with mechanical equipment and chemicals

69. Microwave for processing - new construction

70. Pressurize meat processing smoke houses

71. Reduce energy use in refrigerated transport

72. Demonstration of energy conservation measures

73. Vacuum chilling and storage of red meat

74. Immersion chilling of red meats

75. Reduction of the amount of water used in all meat and poultry processing plants

76. 4-day, 40-hour work week effect on energy consumption, and effect on economies of various plant capacities 
APPENDIX C - RECOMMENDED PROJECTS

Textiles

77. Conversion from pneumatic to mechanical materials handling at gins

78. Ginning waste as a substitute fuel for drying

79. Generation of power for cotton gins by using gin waste

80. Compression process using hydraulic power instead of steam power

81. Reduction of energy consumption in wool scouring

82. Reduction of hot water usage in wetprocessing of cotton-containing textiles

83. Elimination of drying processes in wetprocessing of cotton-containing textiles

84. New fiber-to-yarn techniques for agricultural fibers

85. Field cleaning of seed cotton

86. Improved lint cleaning at gins

87. Improvement of efficiency of gin seed cotton dryers 

- Report No. 18

I. Energy Research and Development Administration. ERDA Workshop on Energy Conservation in Agricultural Production. CONF -760763. Energy Research and Development Administration, Washington, D.C., July 15-16, 1976.

II. Technical and/or End-Use Focus

As implied by the title, this report focuses on agricultural production.

III. Types of Information Provided

1. No review of energy end-use data was made.

2. The potential for energy savings was included for each suggested project.

3. Times to commercialization (or research development times) were estimated.

4. No review of existing research programs was made.

5. No methodology for identifying R\&D opportunities was given.

IV. R\&D Opportunities

See attached pages.

V. Critical Summary

The time focus of the projects suggested by the workshop participants was very near term: several months to a few years. Given this frame, the projects were generally directed at specific uses and few generic activities were recommended. The report nonetheless provides a good overview of immediate needs in agricultural production.

Though the workshop members were probably comprehensive in their netting of salient needs, justification in terms of energy conservation potential is uncertain because the sources were not cited.

VI. Comments

Reviewed by $\mathrm{GJH}$ 


\section{APPENDIX B - Chairmen's Summary Remarks}

Crop Production Systems 21

Animal Production Systems 25

Greenhouses and Other Production systems 29

On-Farm Processing 31

Water Resources 35

Utilization of Agricultural By-Products 39

APPENDIX C - Recommended Projects

Crop Production Systems

1. Reduction of Transport Energy in Crop Production

2. Energy Conservation through Reduced Tillage

3. Cropping for More Energy-Efficient Food Chains

4. Loss Reduction in Harvesting

5. Multiple Cropping for Energy Efficiency

6. Reduced Weather Vulnerability

7. Alternate Portable Fuel systems for Aqricultural production

8. A Systems Approach to Energy Conservation in Agricultural production

9. Effect of Continuous Crop Residue Removal on Soil productivity

10. Agricultural Utilization of Non-Agricultural By-Products

11. Energy Conservation through Genetic Improvement

12. Increase Efficiency of Nutrient Utilization

13. Energy Reduction through Increased Pesticide Efficiency 
APPENDIX C - Recommended Projects (continued)

Crop Production Systems (continued).

14. Biological Nitrogen Fixation

Animal Production Systems

15. Improvement of the Energetic Efficiency of Animals By Physiological and Nutritional Means

16. Matching Animal Production with Processing or Manufacturing Process

17. Recovery and Development of Energy from Animal Excreta

18. Conservation of Energy Used for Handling Livestock Waste

19. Conservation of Energy in the Construction and Use of Buildings for Livestock Production

20. Conservation of Energy Used to Control the Environment in Livestock Housing

21. Improve Motor Efficiency and Make More Efficient Use of Motors in Farmstead Equipment

22. Energy Conservation in Feed-Handing Equi.pment

23. Minimizing Energy Costs of Environmental Modifications of Animal Production Systems

24. Energy Self-Sufficient Animal Production Systems

25. Future Requirements for Energy in Animal and Poultry Production

26. Conserving Energy in Transport

27. Integrated Milk Production and Sanitation systems 
APPENDIX C - Recommended Projects (continued)

Animal Production Systems (continued)

28. Feasibility of the Utilization of Industrial Low Temperature Waste Heat

29. Develop and Demonstrate Forage and Grain Handling Systems

30. Promotion, Acceptance, and Adoption of Energy-Saving Methods of Livestock Production

31. Potential for Energy-Flexible Systems

32. The Facts of Meat Animals and Energy Use

33. Development of Effective Animal Manure Management Systems

34. Improved Milk-Handling Procedures

Greenhouses and Other Production Systems

35. Energy-Effective Use of Iighting Systems for Heating and Constant Year-Round Production

36. Reducing Heat Losses in Greenhouses

37. Reducing Energy Consumption for Cooling Greenhouses

38. Improved Greenhouse Heating Systems

39. Greenhouse Orientation and Shape

40. Increased Space Utilization in Greenhouses

41. Development of New Construction Materials for Greenhouses

42. Biological and Physiological Alterations of Crops

43. Systems Analysis of Intensive Vegetable, Grain and Flower Production for Energy Conservation 
APDENDIX C - Reccmmended Projects (continued)

Greenhouses and Other Production Systems (continued)

44. Reduction of Energy Use in the Transportation and Marketing of Vegetables, Fruits, and Flowers

45. Substitution of Scarce Fuels

46. Combination Systems

47. Increasing Efficiency of MaterialsHandling Systems in Aquacultural Production

48. Utilizing Low Grade waste Heat in Aquacultural Production

49. Improving Efficiencies of Vehicle Use in Aquacultural Production

50. Domestic Aquacultural Production

51. Combination Systems for Aquacultural Production

52. Establishing Data Base for Energy Conservation in Controlled-Environment Agriculture

On-Farm Processing

53. Annual Cycle Energy Systens Applied to Farm Processing

54. On-Farm Milk Volume Reduction Systems

55. Demonstrating Energy Conservation through Recycled Heat from Dairy Farm Milk Refrigeration Units

56. Energy Conserved and Effect on Electrical Demands Resulting from Peak Load Shifting

57. Establishing Energy Use Patterns for Iivestock Feed Processing/Handling systems

58. Grain Dryer Fuel from Non-Grain Plant Parts 
APPENDIX C - Recommended Projects (continued)

On-Farm Processing (continued)

59. Heat Recovery Systems for Crop Dryers

60. Low Temperature Grain Drying

61. Innovative Design of Grain Dryers

62. Investigation of the Technical and Economic Feasibility of a Coal-Fired Grain Dryer

63. Evaluation of Technical and Economic Feasibility of Heat Pumps for Grain Drying

64. Direct Oil-Fired Burner for Crop Drying

65. Utilization of Lined Tunnels Below Grade as a Heat Exchanger

66. Preservatives to Delay Drying as Applied to Cereal Grains

67. Development and Demonstration of Dryeration

68. Use of Industrial Waste Heat for Crop Drying

69. Containerization for Low-Energy Grain Handling

Water Resources

70. National Impacts of Energy Conservation in Water Resources

71. Energy Limitations for Reclamation of Submerged Lands

72. Irrigation Management

73. Energy Conservation Due to Improved Pumping Plant Efficiencies 
APPENDIX C - Recommended Projects (continued)

Vater Resources (continued)

74. Development of Educational Material for Evaluating Alternatives to Improve Pumping. Plant Efficiency

75. Alternate Sources of Energy for Pumping Water

76. Alternate Source of Energy - Coal-Fired Steam Turbine

77. Wind as a Source of Energy for Pumping Water

78. Solar Energy as an Alternate Source of Energy for Pumping Water

79. Improvement of Motor and Engine Efficiencies

80. Improvement of Pump Efficiency

81. Development of New Well Screens and Gravel Pack Procedures to Reduce Drawdown in Wells

82. Irrigation System Efficiency

83. Water Application Efficiency

84. Crop Response to Limited Water and Nitrogen Input

85. Use of Waste Water to Replace Pumped Water

86. Energy Conservation in Agricultural Drainage Installation

87. Energy Conservation by Improved Drainage Pumping Plant Efficiencies

88. Drainage Materials and Design Practices for Energy Conservation

89. Development of a Simplified Flow Meter

90. Measures for Retaining Water on Land to Reduce Irrigation Pumping 
APPENDIX C - Recommended Projects (continued)

Water Resources (continued)

91. Water Harvesting as an Alternative to Pumped Irrigation

92. Recharge of Aquifiers to Reduce Lift for Pumped Irrigation

Utilization of Agricultural By-Products

93. Development of Methods for Harvesting, Storing and Transporting Crop Residues Considering off-the-Farm Use

94. Availability of Field Crop Residues for Specific Crops and Regions

95. Definition of Economical Methods of Whole Crop Harvesting for Optimum Grain Quality, Energy Use, and Residues Collection

96. Practicality of the Redesign of Grain Crops to Maintain Grain Yield But Increase Total Biomass

97. Demonstration of Direct Combustion of Field Crop Residues for On-the-Farm Use

98. Demonstration of Direct Combustion of Field Crop Residues for Off-the-Farm Use

99. Define and Demonstrate Gas-Generating Systems for Farm and Off-the-Farm Use

100. Define and Demonstrate Optimum Liquid Fuel Production Systems

101. Define and Demonstrate Optimum Systems for Production of Industrial Chemicals from Collected Agricultural Residues

102. Increase Developmental Efforts on the Enzymatic Hydrolysis of Cellulosic Residues to Sugars

103. Demonstration of Practical Methods of $\mathrm{CO}_{2}$ Enrichment for Increasing Crop Growth 
APPENDIX C - Recommended Projects (continued)

Utilization of Agricultural By-Products (continued)

104. Integration of Animal Feeding, Fuel Production and Fertilizer Use in the Use of Crop Residues and Animal Wastes

105. Use of Mineral Content Derived from Crop Residues

106. Relative Efficiency and Economic Aspects of Utilizing Manure

107. Development of Energy-Efficient Equipment to Collect, Process, Store and Re-Feed Lives tock Wastes

108. Health and Consumer Aspects in the Feeding of Animal Wastes to Livestock

109. Demonstration of Cascade Feeding Systems for Poultry, Steers, and Brood Cattle

110. Feasibility of Converting Feedlot Wastes to Industrially Useful Oxychemicals 


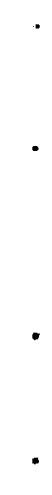

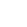


- $\quad$ Report No. 19

I. Energy Research and Development Administration. ERDA Workshop on Fluid Waste Heat Recovery and Utilization. CONF-761157. Division of Industrial Energy Conservation, Energy Research and Development Administration, Washington, D.C., November 17-19, 1976.

II. Technical and/or End-Use Focus

The majority of the workshops concerned segments of the industrial sector: agriculture, chemicals, food processing, metals, petroleum, pulp and paper, and textiles. An additional group discussed community systems.

III. Types of Information Provided

1. No review of energy end-use data was made.

2. For each suggested project, energy savings were estimated.

3. R\&D times for many of the projects are estimated.

4. No review of existing research programs was made.

5. The workshop participants were chosen from those recommended from professional societies and industry. The participants did not discuss the methods used to arrive at their suggestions.

IV. R\&D Opportunities

See attached sheets for general descriptions of R\&D needs.

V. Critical Summary

The techical and professional backgrounds of the participants contributed toward presenting a comprehensive sampling of salient low temperature heat recovery needs in the various industries.

The R\&D projects recommended were directed at specific end uses and were generally short-term efforts - several months to a year. The participants did not investigate the generic potential of ihe projects suggested, but most of the projects can be classified in one of eight broader headings: 1) system studies, 2) decontamination, 3) heat exchangers, 4) augmentation techniques, 5) enhancement iechniques, 6) environmental conditioning, 7) storage and transport, and 8 ) process modification.

Though potential energy savings were estimated for each of the projects the sources of the estimates were not given. The numbers thus involve a fair degree of uncertainty.

VI. Comments

This workshop and document motivated the work reported in the report titled DOE Program Objectives, Fluid Waste Heat Recovery and Utilization, February, 1978.

Reviewed by $\mathrm{GJH}$ 


\section{APPENDIX B - CHAIRMEN'S SUMMARY REMARKS}

Agriculture

Chemicals

Community Systems

Food Processing

Petroleun

Pulp and Paper

\section{APPENDIX C - RECOMMENDED PROJECTS}

Agriculture

1. Heat and Mass Transfer in Soils as Applied to Soil Warming

2. Distribution for Piping Systems for Soil Warming and Subsurface Irrigation

3. Crop Variety Testing in Waste Heat-Warmed Soil Conditions

4. Utilization of Area Waste Heat by Area Agricuture

5. Intensive Integrated Fish Production Utilizing Waste Heat

C. Utilizing Waste Heat from Steam Electric-Generating Plants in the Culture of Aquatic Food

7. Development of Intensive Catfish Fingerling Production System Utilizing Power Plant Discharge Water

8. Large Scale Environmental Control Complexes

9. Heating Greenhouse Crop-Rooting Media and Enhancement of Greenhouse Above Root Media Atmosphere with $\mathrm{CO}_{2}$ from Relatively Clean Stack Heating 
10. Utilizing Power Plant Waste Heat for Greenhouse Environmental Control

11. Utilization of Waste Heat in Closed-Loop, Dehydration-Pelletizing Systems

12. Methods for Waste Heat Transport with Distance Limitations

13. Identification of Potential Areas of Using Waste Heat for Crop Drying

14. Heat Storage for Agricultural Uses

15. Design Equations for Heat Pipes/Heat Exchangers

16. Mechanisms for Utilizing Waste Heat to Dry Agricultural Crops

17. Economic Feasibility of Soil Warming Systems

18. Production of Fresh Water in Arid Regions Using Waste Heat

19. Environmental Control of Poultry Houses Utilizing Waste Heat Contained in Liquid Streams

20. Environmental Control of Swine Houses Utilizing Waste Heat Contained in Liquid Streams

21. Use of Low Grade Energy Contained in Liquid Effluents for Dairy Operations

22. Survey of Waste Heat Recovery and Utilization for Agricultural Applications

23. Technology and Information Transfer

24. Advancement of Refrigeration and Air Conditioning Technologies Utilizing Waste Heat

25. Systems Approach to Utilizing Waste Heat in Intensive Crop Production and Marketing 
26. Utilization of Waste Heat to Enhance Biogas Production

27. Frost Control via Waste Heat Sources

28. Waste Heat Utilization to Improve Quality of Inland Water Streams

29. Improvement of Biogas Production System Reliability

30. Enhanced Water Plant Production for Food; Feed, and Biomass via Waste Heat

31. Use of Waste Heat to Enhance Composting

Chemicals

32. Handbook on Waste Heat Recovery Systems and Applications

33. Study of Possible Modes for Federal Incentives Regarding Energy Conservation

34. Lower Cost Heat Exchangers

35. Low Cost Chilled Water

36. Industrial Heat Pumps

37. Expander Technology

38. Exchanger Coolant Flow Control

39. Pipe Tracing, Monitoring and Control

40. Determination of Fluid Physical and Thermodynamic Properties

41. Study of Insulation Characteristics

Community Systems

42. Inventory of Ener.gy Sources and Energy Needs 
43. Impact of Waste Heat Utilization on Power Plant Engineering

44. Energy Transport and Storage

45. Utilizing Effluent Waste Energy in Heating/Cooling Buildings

46. Waste Heat Utilization for Multiculture Biological Systems

47. Recreational Use of Waste Heat

48. Waste Heat for Desalination

Food Processing

49. Refrigeration Waste Heat Recovery

50. Dryer Exhaust Recovery with Fouling Control

51. Heat Storage in Small Volumes

52. Vapor Compression with Wetter Steam

53. Improve the Efficiency of Absorbers for $140^{\circ} \mathrm{F}$. Input Water

54. Heat Pump or Heat Pipe for $250^{\circ} \mathrm{F}$. Waste Heat Elevated to $400^{\circ} \mathrm{F}$. in Cereal Manufacturing

55. Waste Water $100^{\circ} \mathrm{F}$. to $180^{\circ} \mathrm{F}$. for Sanitizing and Thawing

56. Increase of Water Temperature for Clean-up Using Solar Augmentation

57. Heat Exchanger Cleaning and Filtering for Fouling Prevention

58. Reuse of Hot or Tempered Water Through Filtration

59. Recovery of Contaminated Condensate for Reuse 
60. Electrical Production During Generation of Low Pressure Steam

61. Fuel Cell Application

Meta1s

62. Heat Exchanger Development

63. Flexible Membrane Heat Exchanger Development

64. Bleedwater Chemical Treatment

65. Vapor Recompression of $125^{\circ} \mathrm{F}$. Steam

66. Recover Energy from Spent Bauxite Discharge

67. Source-Sink Location Coordination

Petroleum

68. Low Level Waste Heat Recovery Evaluation

Pulp and Paper

69. Converting Waste Heat in Low Temperature Water to Higher Temperature Water via Heat Pump

73. Conserving Hood Waste Heat via Heat Pumps

71. Improved Low Temperature Heat Exchangers

72. ASME Coding of Compact Heat Exchangers

73. Application of Fluidized Bed Heat Exchangers to Waste Heat Recovery

74. Investigation of Feasibility of Bark Drying for Heat Recovery

75. Utilization of Heat Sinks or Balancing Condensers 
76. Economics of Solar Augmentation and Conceptual Design of System for Waste Stream Heat Recovery in Pulp and Paper Industry

77. Improved Paper Machine Hood Economizers

Textiles

78. Development of a Moisture Meter

79. Mass and Energy flows in a Textile Finishing Plant

80. Wet Process Modification

81. Tenter Frame Drying

82. Dewatering Processes

83. Heat Pump Utilization of Waste Heat Streams

84. Application of Heat Pumps to Specific Textile Processes

85. Heat Recovery from Boiler Stack Gas

86. Anaerobic Digestion of Concentrated Waste

87. Projection of Future Solar Collector Costs

88. Foam Dyeing

89. Het-on-Wet Dyeing and Finishing

90. Spray Dyeing and Finishing

91. Vapor Dyeing and Finishing

92. Electrostatic Deposition of Dyes and Finishes

93. Radiation Curing 


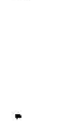

.

. 
- Report No. 20

I. Energy Research and Development Administration. ERDA Workshop on High

Temperature Waste Heat Recovery and Utilization. Division of Industrial

Energy Conservation, Energy Research and Development Administration, Washington, D.C., August 25 and 26, 1977.

II. Technical and/or End-Use Focus

The majority of the workshop sessions concerned segments of the industrial sector: cement and ceramics, chemicals, glass, non-ferrous metals, petroleum, and iron and steel. An additional group discussed integrated industrial parks.

III. Types of Information Provided

1. No review of energy end-use data was made.

2. Potential energy savings were occasionally included with each of the project suggestions.

3. Expected R\&D times were estimated for each of the suggested projects.

4. No review of times to commercialization was made.

5. No methodology for identifying R\&D opportunities was given.

IV. R\&D Opportunities

See attached sheets for a summary.

V. Critical Summary

Industrial representatives contributed to this workshop by presenting a comprehensive sampling of salient high temperature heat recovery needs in the various industries.

The R\&D projects recommended were directed at specific end uses and were generally short term; a few years. The participants did not attempt to investigate the generic potential of the projects suggested, but most projects can be classified under one of the three broader headings: 1) systems studies, 2) process modification, and 3) heat recovery technology.

Though potential energy savings were estimated for each of the projects, the sources of the estimates were not given. The numbers thus involved a fair degree of uncertainty.

\section{Comments}

The format of this workshop is very similar to a previously held workshop, Fluid Waste Heat Recovery and Utilization, November 17-19, 1976 (CONF-761157). The fluid waste heat workshop concerns potential energy savings in low temperature streams, thus complementing the information provided in this high temperature workshop.

Reviewed by $\mathrm{GJH}$ 
Topic

Industry

Group
Project Number

\section{Systems Studies}

- thermodynamic analysis of energy-intensive processes

- thermal audit of waste heat sources

- energy storage and transport
Glass

Industrial Parks

Chemicals

Glass

Cement \& Ceramics

Chemicals

Industrial Parks

Non-Ferrous Metals

Petroleum

Iron \& Steel

Glass

Petroleum

Industrial Parks
11

30,34

12

$18,19,20$

7

17

31,32

39

48

52,54

24,27

41

33

\footnotetext{
metering
}

Process Modification

- absorption-refrigeration Chemicals 16

Petroleum 43

- stack gas heat recovery

Chemicals 10

Glass 28

Industrial Parks 35

Petroleum 47

- high temperature preheated combustion

Cement \& Ceramics

Chemicals

19 air and burners

- oxygen-enriched

Non-Ferrous Metals

37

Petroleum

46

Iron \& Steel

52

Glass

26

combustion air

Cement \& Ceramics

Glass

Iron \& Steel

5,6

25

53 


\section{Topic}

Heat Recovery Technology

- heat exchangers

- heat pumps

- bottoming cycles

- electrical power generation
Industry

Group

Project Number

$\begin{array}{ll}\text { Cement \& Ceramics } & 1,2,3,6,7 \\ \text { Chemicals } & 10,15 \\ \text { Glass } & 21,22,23, \\ & 29,28 \\ \text { Industrial Parks } & 35 \\ \text { Non-Ferrous Metals } & 36,38 \\ \text { Petroleum } & 44,45,47 \\ \text { Iron \& Steel } & 49,50,51, \\ & 52\end{array}$

Cement \& Ceramics

Petroleum

4

Cement \& Ceramics

Chemicals

Cement \& Ceramics

Chemicals

Petroleum

Iron \& Steel
42

6

10,15

8,9

13,14

40,44

49 
- 
- Report No. 21

I. Energy Task Group, Comittee on Materials (COMAT). Federal Council for Science and Technology, Needs for Energy-Related Materials Research and Development. Volume 1. Near-Term Energy Program. ERDA 76-28V1 (Preliminary Version), ERDA Technical Information Center, Oak Ridge, Tennessee. Has 5 appendices. Executive Summary published in 1977 as NP-21665. Available from National Technical Information Service, Springfield, VA. 1976.

\section{Technical and/or End-Use Focus}

Seven study panels addressed the following areas:

- Fossil Energy

- Nuclear Energy

- Solar and Geothermal Energy

- Energy Conversion, Storage, and Transmission

- Conservation and Recovery of Materials and Energy

- Materials Supply and Management

- Multi-Impact Basic Research and Exploratory Development

III. Types of Information Provided

1. Energy end use data not reviewed.

2. Energy savings from research not estimated.

3. Time to commercialization not considered.

4. Existing research programs reviewed broadly in main text. Some specific programs and funding levels are reviewed in the Appendices.

5. Report did not present a methodology for identifying research. Panels of experts reviewed existing research programs and then recommended changes in program levels and priorities.

IV. R\&D Opportunities

- The list of R\&D opportunities is, by necessity, long and broadly stated. They are summarized in the Executive Summary. Somewhat more detail, although still general, is available in the body of the report and Appendices.

- Existing research funding levels for various areas are summarized in the attached tables. The report and Appendices contain some additional detail and discussion.

- References for the four panel reports that have the most relevance to energy conservation R\&D are attached. 
V. Critical Summary

This COMAT report presents a broad view of materials R\&D opportunities for energy supply, conversion and use. This report covers R\&D opportunities through 1985. No report was issued on intermediate term (to 2000) and long-term R\&D opportunities. Several earlier reports had described the needs for energy-related materials R\&D, such as the following reports by the National Academy of Sciences:

- Materials Technology in the Near Term Energy Program. 1974.

- Materials and Man's Needs. 1974.

- Mineral Resouces and the Environment. 1975.

The intent of the subject COMAT report was to complement previous materials R\&D opportunities reports by specifying and setting priorities on the materials R\&D efforts needed to meet the objectives of the national energy plans (ERDA-48 and later ERDA 76-1). To meet these objectives the COMAT report has very little detail. Technical accuracy is not assessable based upon the information provided in the report itself, but it does appear to be very good. The stated R\&D opportunities are not justified in the COMAT report; they are based upon programatic goals (e.g., demonstrated a new process or device by year $X$ ) and the knowledge of the individual panel members. It is noteworthy that the panels were composed exclusively of personnel from government agencies; no private industry participation is evident.

VI. Comments

The report represents the broad government view of energy related materials R\&D opportunities in the year 1976. While little justification of R\&D opportunities is given, their list provides a useful check list to compare against lists coming from other R\&D opportunties lists which originate more directly from studies of material using devices and processes.

Reviewed by WEG. 


\section{Report of Energy Conversion, Storage, and Transmission Panel}

Table 1-PRIORITY RATING AND BUDGET ANALYSIS OF ENERGY CONVERSION MATERIALS R\&D PROGRAM (NEAR-TERM)

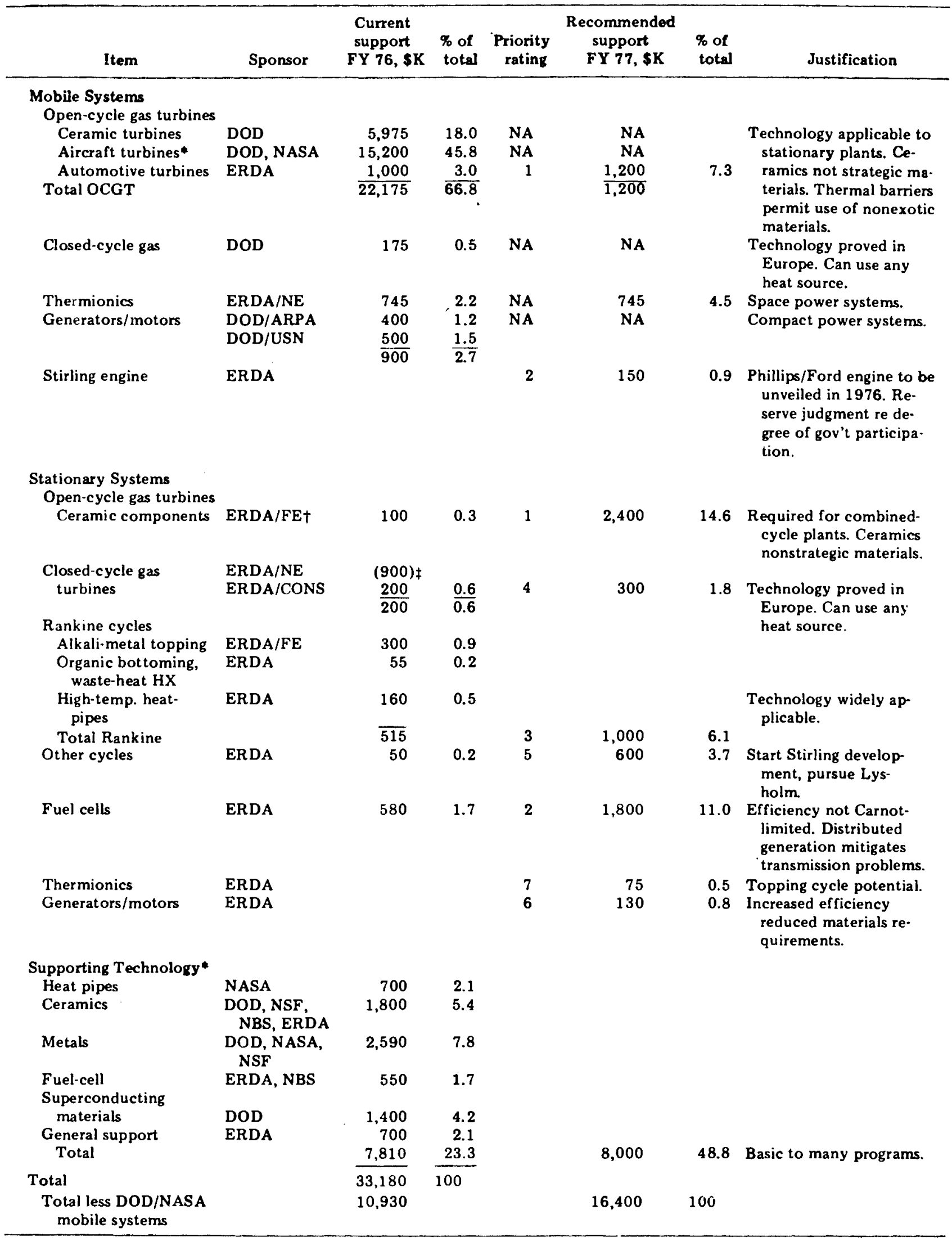

* DOD data incomplete.

†Estimate of S. Friedman, ERDA/FE.

B. 133

¥ Not expected to continue, therefore not included in the totals. 


\section{REFERENCES}

1. Creating Energy Choices for the Future, A National Plan for Energy Research, Development and Demonstration, Vol. 2, Program Implementation, p. 58, ERDA Report ERDA-48, 1975.

2. Ref. 1, p. 171.

3. Ref. 1, p. 7.

4. An Analysis of the ERDA Plan and Program, pp. 68-69, U. S. Congress, Office of Technology Assessment, October 1975 .

5. Ref. 1 , p. 78 .

6. Record of the Tenth Intersociety Energy Conversion Engineering Conference, August 18-22, 1975, IEEE Catalog No. 75CHO 983-7 TAB, pp. 496-512.

7. The Stirling Automotive Power System, Chap. 6 in Should We Have a New Engine? An Automobile Power System Evaluation Vol. 2, Technical Reports, Report JPL-SP43-17, pp. 6-27, California Institute of Technology, August 1975.

8. Ref. 7, pp. 6-28.

9. Ref. 1, p. 65.

10. Ref. 1, pp. 78-79.

11. Ref. 1, p. 68.

12. Ref. 1, p. 61.

13. Ref. 1, p. 63. 


\section{Report of Conservation and Recovery of Materials and Energy Panel}

Table 8-BUDGET ANALYSIS-NEAR-TERM PROGRAM

\begin{tabular}{|c|c|c|c|c|}
\hline Item or program & $\begin{array}{c}\text { Approximate } \\
\text { budget for } \\
\text { FY 76, } \$ 1000\end{array}$ & $\begin{array}{l}\% \text { of } \\
\text { total }\end{array}$ & $\begin{array}{l}\text { Recommended } \\
\text { budget for } \\
\text { FY } 77, \$ 1000\end{array}$ & $\begin{array}{l}\text { \% of } \\
\text { total }\end{array}$ \\
\hline I. Reduced energy consumption in the materials cycle & $(19,850)^{*}$ & $(92)^{*}$ & $(28,500)^{*}$ & $(88)^{*}$ \\
\hline A. Management of the materials cycle & $(4,549)^{*}$ & $(21)^{*}$ & $(7,200)^{*}$ & $(22)^{*}$ \\
\hline Systems study of the cycle & 685 & 3 & 2,000 & 6 \\
\hline Development of substitute materials & 1,717 & 8 & 2,200 & 7 \\
\hline Improve the data base on energy use in the cycle & $1,440 \dagger$ & 7 & 1,800 & 6 \\
\hline Integrated studies to support policy implementation & 707 & 3 & 1,200 & 4 \\
\hline B. Reduced energy use in materials production & $(6,560)^{*}$ & $(30)^{*}$ & $(10,300)$ & $(32)^{*}$ \\
\hline Assessment of alternate processes & 2,121 & 10 & 3,500 & 11 \\
\hline R\&D on new and improved processes & 3,876 & 18 & 5,800 & 18 \\
\hline Materials science and engineering & 563 & 3 & 1,000 & 3 \\
\hline C. Resources from wastes & $(8,741)^{*}$ & $(41)^{*}$ & $(11,000)^{*}$ & $(34)^{*}$ \\
\hline Materials from urban wastes & 1,189 & 6 & $(1,400)$ & 4 \\
\hline Energy from urban wastes & 2,289 & 11 & 3,500 & 11 \\
\hline Energy and resources from agricultural wastes & 1,180 & 6 & 1,300 & 4 \\
\hline Energy from wood wastes & 278 & $<1$ & 500 & 2 \\
\hline Material from combustion and conversion wastes & 1,440 & 7 & $(1,600)$ & 5 \\
\hline Energy and materials from waste-water sludges & 665 & 3 & 1,000 & 3 \\
\hline Energy and materials from industrial waste & 878 & 4 & $(1,200)$ & 4 \\
\hline All & 822 & 4 & 500 & 2 \\
\hline $\begin{array}{l}\text { II. Materials for improving efficiency in end uses of energy } \\
\text { A. Materials property assessment for emerging energy }\end{array}$ & $(1,684)^{*}$ & $8 *$ & $(3,800)^{*}$ & $(12)^{*}$ \\
\hline technologies & 105 & $(<1)^{*}$ & 500 & 2 \\
\hline B. Materials development to support energy conservation & $(1,579)^{*}$ & $(7)^{*}$ & $(3,300)^{*}$ & $(10)^{*}$ \\
\hline Buildings and consumer products & 530 & 2 & 1,000 & 3 \\
\hline Ind ustrial end use & 1,024 & 5 & 2,000 & 6 \\
\hline Transportation systems and vehicles & 25 & $<1$ & 300 & 1 \\
\hline Totals & 21,534 & $100 \%$ & 32,300 & $100 \%$ \\
\hline
\end{tabular}

* Subtotal.

†The figure for data collection includes about $\$ 250 \mathrm{~K}$ that overlaps with the Materials Supply and Management Panel program.

\section{REFERENCES}

1. Energy Research and Development Administration, A National Plan for Energy Research, Development, and Demonstration: Creating Energy Choices for the Future, Volume I: The Plan. Washington, D.C., U.S. Government Printing Office, ERDA-48, June 1975.

2. Ref. 1, p. III-1.

3. Energy Research and Development Administration, A National Plan for Energy Research, Development, and Demonstration: Creating Energy Choices for the Future, Volume II: Program Implementation. Washington, D.C., U.S. Government Printing Office, ERDA-48, June 1975.

4. Ref. 3, p. 70 .

5. Office of Emergency Preparedness, Energy Conservation, A Staff Study Prepared for the Energy Subcommittee of the Domestic Council, July 1972.

6. Federal Energy Administration, Project Independence Report, November 1974.

7. Energy Policy Project of the Ford Foundation, A Time to Choose: America's Energy Future, Ballinger Publishing Co., Cambridge, Mass., 1974.

8. R. Herrendeen and C. Bullard, Energy Cost of Goods and Services, 1963 and 1967, Document 140, Center for Advanced Computation, University of Illinois, Nove mber 1974.

9. P. F. Chapman, Energy Costs: A Review of Methods, Energy Policy, 2(2): 101 (June 1974).

10. National Science Foundation, Report of the NSFStanford Workshop on Net Energy Analysis, Aug. 25-28, 1975.

11. International Federation of Institutes for Advanced Study, Energy Analysis Workshop on Methodology and Conventions, Aug. 25-30, 1974, Stockholm, Sweden.

12. National Academy of Sciences, Materials Technology in the Near-Term Energy Program: Report of the Ad Hoc Committee to the Science Advisor to the President, p. 51, National Academy of Sciences, Washington, D.C., September 1974 .

13. John B. Wachtman, The Office of Technology Assessment: Overview and Materials Programs, West Coast Meeting, Society of Automotive Engineers, Inc., Warrendale, Pa., August 1975. 


\title{
Report of Materials Supply and Management Panel
}

\author{
REFERENCES
}

Table 4-FUNDING ESTIMATES FOR FEDERAL PROGR AMS ON MATERIALS SUPPLY AND MANAGEMENT

\begin{tabular}{|c|c|c|}
\hline Research program & Sponsor & $\begin{array}{c}\text { FY } 76 \\
\text { funding, } \\
\$ \text { millions }\end{array}$ \\
\hline $\begin{array}{l}\text { Uranium resource assessment } \\
\text { Nuclear processing develop- } \\
\text { ment (gas diffusion, isotope } \\
\text { fuels, laser separator, gas } \\
\text { centrifuge) }\end{array}$ & ERDA & $\begin{array}{l}14.0 \\
14.8\end{array}$ \\
\hline Nuclear waste management & & 25.9 \\
\hline $\begin{array}{l}\text { Materials research } \\
\text { (substitution) }\end{array}$ & & 0.9 \\
\hline $\begin{array}{l}\text { Minerals and materials } \\
\text { information and analyses }\end{array}$ & DOI/BOM & 15.2 \\
\hline $\begin{array}{l}\text { Metallurgy (processes and } \\
\text { substitution) }\end{array}$ & & 22.0 \\
\hline $\begin{array}{l}\text { Minerals and materials resource } \\
\text { information and analyses }\end{array}$ & DOI/USGS & 2.5 \\
\hline $\begin{array}{l}\text { Geological research on mineral } \\
\text { deposits }\end{array}$ & & 12.0 \\
\hline Metal substitutes & & $\begin{array}{l}\text { Included } \\
\text { elsewhere }\end{array}$ \\
\hline $\begin{array}{l}\text { Seabed assessment, structural } \\
\text { materials, resources, geology }\end{array}$ & NSF & 8.6 \\
\hline $\begin{array}{l}\text { Conservation of materials, new } \\
\text { production processes }\end{array}$ & NSF/RANN & 3.3 \\
\hline Efficiency of wood processing & DOA/FS & 6.2 \\
\hline $\begin{array}{l}\text { Extraction and harvesting of } \\
\text { wood }\end{array}$ & & 1.8 \\
\hline $\begin{array}{l}\text { Metallurgical materials proper- } \\
\text { ties and composition analysis }\end{array}$ & NBS & 4.0 \\
\hline $\begin{array}{l}\text { Development of efficient power } \\
\text { plants and designs for ships }\end{array}$ & $\mathrm{DOC}$ & 4.0 \\
\hline $\begin{array}{l}\text { Use of secondary woods, supply } \\
\text { of copper }\end{array}$ & DOS & 0.2 \\
\hline Minerals Attaché Program & & 0.3 \\
\hline $\begin{array}{l}\text { Com-Ply products and innova- } \\
\text { tive piping }\end{array}$ & HUD & 0.1 \\
\hline $\begin{array}{l}\text { Chromium, magnesium, manga- } \\
\text { nese, etc. }\end{array}$ & $\begin{array}{l}\text { Nat. Mat'l } \\
\text { Advisory } \\
\text { Board }\end{array}$ & $\begin{array}{l}\text { Included } \\
\text { elsewhere }\end{array}$ \\
\hline & $\begin{array}{l}\text { Federal } \\
\text { Preparedness } \\
\text { Agency }\end{array}$ & 0.3 \\
\hline TOTAL & & 136.1 \\
\hline
\end{tabular}

1. A National Plan for Energy Research, Development \& Demonstration: Creating Energy Choices"for the Future, Vol. 2, Program Implementation, ERDA Report, ERDA48, June 1975.

2. Federal Energy Administration, Project Independence Report-Task Force Report, Availabilities, Requirements, and Constraints on Materials, Equipment and Construction, 1974.

\section{BIBLIOGRAPHY}

Albers, John P., and Walter J. Bawiec, Non-Fuel Minerals and Materials Needed by the United States Energy Industry - A Preliminary Report, U. S. Geological Survey open-file report, 1975 .

Bennethum, Gary, and L. Courtland Lee, Is Our Account Overdrawn?, Mining Congr. J., 61(9): 33-48 (1975).

Brobst, Donald A., and Walden P. Pratt (Eds.), United States Mineral Resources, U. S. Geological Survey Circular $682,1973$.

Calkins, J. A., Olaf Kays, and E. K. Keefer, CRIB-The Mineral Resources Data Bank of the U.S. Geological Survey, U. S. Geological Survey Circular 681, 1973.

Carlson, Jack W., Reliable Mineral Supply for the Future?, Mining Congr. J., 61(11): 42-47 (1975).

Council on International Economic Policy, Special Report - Critical Imported Materials, Superintendent of Documents, U. S. Government Printing Office, Washington, D. C., 1974.

Energy and Hydrocarbons in the U.S. to 1985, Vol. 2, The Pace Company.

Environmental Quality - 5th Annual Report on Environmental Quality, Council on Environmental Quality, 1974.

Mineral Resources and the Environment, National Research Council, February 1975.

Minerals Yearbooks, U. S. Department of Interior.

National Academy of Sciences-National Research Council, Mineral Resources and the Environment, National Academy of Sciences, Washington, D. C., 1975.

Office of Business Economics-Economic Research Service, Projections, U. S. Water Resources Council, 1972.

Statistical Abstracts, Bureau of the Census.

U. S. Bureau of Mines, The Bureau of Mines Minerals Availability System and Resource Classification Manual, U. S. Bureau of Mines Information Circular 8654, 1974.

U. S. Department of the Interior, Mining and Minerals Policy, 1975, and Commodity Data Summaries, 1975, Annual Report of the Secretary of the Interior under the Mining and Minerals Policy Act of 1970 (P.L. 91-631), Parts 1 and 2, Superintendent of Documents, U. S. Government Printing Office, 1975.

The U.S. Energy Problem, Vol. 2, Appendices, Part B, Inter Technology Corporation, RANN, November 1974.

U. S. Geological Survey, Mineral Resource Perspectives 1975, U. S. Geological Survey Professional Paper 940, 1975.

U. S. National Commission on Materials Policy, Material Needs and the Environment Today and Tomorrow, Superintendent of Documents, U. S. Government Printing Office, Washington, D. C., 1973. 
Table 1-PROGRAM FOR BASIC RESEARCH FOR NEAR-TERM GOALS

(Parentheses enclose Materials Sciences, DPR, ERDA, total for topic)

\begin{tabular}{|c|c|c|c|c|c|c|}
\hline & \multicolumn{6}{|c|}{ Funding, millions of dollars (1976) } \\
\hline & FY 76 & 77 & 78 & 79 & 80 & 81 \\
\hline Metals and alloy development & $(13.4)$ & & & & & \\
\hline Fracture & 0.5 & 1 & 1.5 & 2 & 2.5 & 3 \\
\hline Creep mechanisms & 0.5 & 2 & 3 & 3 & 3 & 3 \\
\hline Stress rupture life & & 2 & 3 & 3 & 3 & 3 \\
\hline \multicolumn{7}{|l|}{ Stress rupture life with } \\
\hline cyclic loading & 0.4 & 1 & 1 & 1 & 1 & 1 \\
\hline Stress corrosion cracking & 0.5 & 3 & 4 & 5 & 6 & 7 \\
\hline Thermodynamics & & 1 & 1.5 & 2 & 2.5 & 3 \\
\hline Coatings development & 0.3 & 2 & 2 & 2 & 2 & 2 \\
\hline \multicolumn{7}{|l|}{ Theory/modeling } \\
\hline (lifetime pred'n) & 0.3 & 1 & 1.5 & 2 & 2.5 & 3 \\
\hline Erosion mechanisms & 0.4 & 2 & 2.5 & 3 & 3 & 3 \\
\hline Corrosion mechanisms & 0.5 & 3 & 3.5 & 4 & 5 & 6 \\
\hline Thermodynamics & 0.5 & 1 & 1.5 & 1.5 & 1.5 & 1.5 \\
\hline Kinetics & 0.5 & 3 & 3 & 3 & 3 & 3 \\
\hline Hydrogen embrittlement & 0.5 & 2 & 3 & 4 & 5 & 5 \\
\hline Thermodynamics & 0.3 & 2 & 3 & 4 & 4 & 4 \\
\hline Hydride (structures) & 0.5 & 1 & 1.5 & 2 & 2 & 2 \\
\hline \multicolumn{7}{|l|}{$\begin{array}{l}\text { Metals and alloys (for light-water } \\
\text { reactors) }\end{array}$} \\
\hline Stress corrosion cracking & 0.5 & 3 & 3 & 3 & 3 & 3 \\
\hline Radiation effects & 7 & 8 & 9 & 10 & 10 & 10 \\
\hline Welding and joining & 0.2 & 1.5 & 2 & 2.5 & 2.5 & 2.5 \\
\hline \multicolumn{7}{|l|}{ Ceramics } \\
\hline Slag properties & 0.5 & 2 & 2.5 & 3 & 3 & 3 \\
\hline Refractories (corrosion) & & 0.5 & 1 & 1.5 & 2 & 2 \\
\hline Thermodynamics & 0.5 & 0.5 & 1 & 1.5 & 2 & 3 \\
\hline Kinetics & 0.2 & 0.5 & 1 & 1.5 & 2 & 3 \\
\hline Microstructure effects & 0.2 & 0.5 & 1 & 1.5 & 2 & 3 \\
\hline Temperature-gradient effects & 0.2 & 0.5 & 1 & 1 & 1 & 1 \\
\hline Erosion & 0.2 & 0.5 & 1 & 1.5 & 2 & 2 \\
\hline Thermal shock studies & 0.1 & 0.5 & 1 & 1.5 & 2 & 3 \\
\hline Fracture mechanics & 0.2 & 0.5 & 1 & 1.5 & 2 & 3 \\
\hline Microstructure development & 0.5 & 1 & 1.5 & 2 & 2.5 & 3 \\
\hline Nonoxide ceramics & 0.5 & 2 & 2.5 & 3 & 3.5 & 4 \\
\hline Processing & 2 & 2.5 & 3 & 3 & 3 & 3 \\
\hline Mechanisms of naw formation & & 1.5 & 2 & 3 & 3 & 3 \\
\hline Scale-up & & 1 & 1.5 & 2 & 2.5 & 3 \\
\hline Single-crystal growth & 0.3 & 1 & 1 & 1 & 1 & 1 \\
\hline Crack-growth mechanisms & & 0.5 & 1 & 1.5 & 2 & 3 \\
\hline Variable environments & & 0.5 & 0.5 & 0.5 & 0.5 & 0.5 \\
\hline Design techniques (brittle) & & 1 & 1.5 & 2 & 2 & 2 \\
\hline Design techniques (composites) & & 0.5 & 1 & 1.5 & 2 & 3 \\
\hline \multicolumn{7}{|l|}{ Thermal-insulation studies } \\
\hline Bulk conductivity & 0.2 & 0.5 & 1 & 1.5 & 2 & 3 \\
\hline IR coating materials & & 0.5 & 1 & 1.5 & 2 & 2.5 \\
\hline Measurement developments & & 0.5 & 1 & 1 & 1 & 1 \\
\hline Polymers & $(0.3)$ & & & & & \\
\hline & 5 \\
\hline Ultraviolet degradation & & & & & & \\
\hline mechanisms & & 0.5 & 1 & 1.5 & 2 & 2.5 \\
\hline Corrosion & & 0.5 & 1 & 1.5 & 2 & 2.5 \\
\hline Crazing & & 0.5 & 1 & 1.5 & 2 & 2.5 \\
\hline Coal chemistry & & 3 & 4 & 4 & 4 & 4 \\
\hline Coal structure & & 0.5 & 1 & 1 & 1 & 1 \\
\hline Amorphous carbons & & 0.5 & 1 & 1.5 & 2 & 2.5 \\
\hline Composites & $(1.0)$ & 2 & 3 & 4 & 5 & 6 \\
\hline Fiber development & & 2 & 3 & 4 & 4 & 4 \\
\hline Interface bonding & & 1 & 1.5 & 1.5 & 1.5 & 1.5 \\
\hline Micromechanics & & 0.5 & 1 & 1.5 & 1.5 & 2 \\
\hline Surfaces & (3) & & & & & \\
\hline Corrosion films & & 2 & 3 & 4 & 5 & 5 \\
\hline Catalysis & & 2 & 3 & 4 & 5 & 5 \\
\hline Equipment/instruments & & 15 & & & & \\
\hline Totals & $\overline{23}$ & 90 & $\overline{105}$ & 129 & $\overline{147}$ & $\overline{163.5}$ \\
\hline
\end{tabular}




\section{REFERENCES}

1. A National Plan for Energy Research, Development and Demonstration, ERDA Report ERDA-48, Vols. 1 and 2, 1975.

2. Exploring Energy Choices, Ford Foundation, 1974.

3. Materials Technology in the Near-Term Energy Program, National Academy of Sciences, 1974.

4. Materials and Man's Needs (COSMAT Report), National Academy of Sciences, 1974.

5. Report of the Committee on Structural Ceramics, Report AB-320, National Academy of Sciences, 1975.

6. Critical Needs and Opportunities in Fundamental Ceramics Research: MIT Meeting Summary, ERDA Report ERDA-9, 1975.

7. Thermodynamics and National Energy Problems, National Academy of Sciences, 1974.

8. Report on the Federal R\&D Program for FY 76, Federal Council for Science and Technology, Superintendent of Documents, U.S. Government Printing Office, Washington, D.C., 1975.

9. Materials Sciences Programs, FY 1975, Division of Physical Research, ERDA Report ERDA-55, July 1975.

10. Inventory of Federally Supported Materials R\&D for FY 76, COMAT Report, Federal Council for Science and Technology. 


\section{- Report No. 22}

I. The Engineering Societies Commission on Energy (ESCOE). Basic Research in Engineering: Advanced Industrial Technology. U.S. Department of Energy, Washington, D.C., February 1979.

II. Technical and/or End-Use Focus

This report focused on energy conservation methods in industrial technology. Specific areas addressed were: design methods, manufacturing processes, industrial sensors and measurement techniques, and tribology.

\section{Types of Information Provided}

1. Energy end-use data were discussed qualitatively as certain manufacturing processes were discussed. The primary emphas is for data presentation was an energy supply source.

2. No energy savings were estimated.

3. No times to commercialization were given.

4. No review of existing research programs was made.

5. Research opportunities were chosen by committee concensus according to the following criteria:

- potential for major breakthrough

- potential for fast commercialization

- critical information for filling technology gaps

- energy and economic advantages

- significant advance in engineering technology base. However, methods for analyzing energy distributions and uses in industrial processes were recommended for further study.

\section{Individual Research Needs Were Described as Follows :}

1. Design

- Data bank and advanced Methodology Handbook incorporating life cycle energy accounting.

- Greater incorporation of computer-aided design, computational methods, and optimization techniques.

2. Manufacturing Processes

- Advance physical understanding and mathematical modeling techniques.

- Analysis of energy required for various materials and processes to produce a specific part.

- Methods to assess and reduce net energy content of manufactured parts (i.e. starting with new net shape forms in machining processes).

3. Sensors and Measurement Techniques

- Real-time process control for manufacturing operations.

- Quantitative NDE for energy conservation, transmission and and production systems.

- Automated inspection systems for remote hazardous environments.

- Sensors for well logging and minerals exploration.

4. Tribology

- Self powered sensors for remote monitoring. Research opportunities were reviewed from "Strategy for Energy Conservation through Tribology" by Pinkus and Wilcock. 
v. Critical Summary

The qualitative nature of much of this report indicated that the understanding of basic industrial processes is insufficient in many cases to adequately define needed research. Therefore, recommendations were made for further study to classify these processes and develop methodologies in relation to energy use analysis.

Instrumentation and measurement systems were considered to have sufficient technological basis to recommend specific programs and est imate costs.

The emphasis of the report was on energy conservation for the production of small discrete batches of manufactured components, since $75 \%$ of all metal parts are produced in this manner.

The report in general was oriented toward long term research goals.

\section{Comments}

None.

Reviewed by REW. 
- Report No. 23

I. The Engineering Societies Commission on Energy (ESCOE). Basic Research in Engineering, Fluid Dynamics and Thermal Processes. FE-2468-54. Department of Energy, Washington, D.C., August 1979.

II. Technical and/or End-Use Focus

As the title implies, the technical focus of the paper is fluid dynamics and thermal processes. End-use discussions include the industrial and transportation sectors with most examples relating to the former.

II I. Types of Information Provided

1. No end-use data were reviewed.

2. No estimates of energy savings were given.

3. No times to commercialization for technologies were given.

4. No detailed review of existing programs was described.

5. The methodology used was that of a survey. Initially, ASME sections relating to the topic were consulted. 600 questionnaires were sent out from which 170 'useful' responses were received. The information was categorized into general areas and presented by groups of ESCOE members.

IV. R\&D Opportunities

See attached pages.

V. Critical Summary

This is a very technically or iented report concerning basic research needs in fluid dynamics and some thermal processes. The research was not suggested with energy conservation as a primary goal. Increased energy efficiency was assumed to be a natural consequence of a greater basic understanding of a process of phenomenon. This can be seen in the R\&D need summaries attached, in which the reason for the needs is technical justification.

Through the survey/workshop method used in generating the report, a wide breadth of activities was collected. The descriptions of the activities are thorough and are equivalent to the "Research Activity" or "task" level.

As a technical document, this report rates highly. The primary deficiency of the report is the lack of more in depth reasons for needs in terms of end use energy or process improvements.

VI. Comments

Reviewed by $\mathrm{GJH}$ 
Table 2.4: BASIC RESEARCH NEEDS INVENTORY

Fluid Dynamics and Thermal Processes, Fluid Flow

Primary Research Category: Multiphase Flows

Secondary Research Category: Fundamental Understanding

\begin{tabular}{|c|c|c|}
\hline Researen Needed & Application & Reason for Need \\
\hline Fielo Equations & reneral & $\begin{array}{l}\text { Determine ance and for all the } \\
\text { proper form for the space - time } \\
\text { overaged field equations to resolve } \\
\text { questions of consistancy }\end{array}$ \\
\hline $\begin{array}{l}\text { General extension of } \\
\text { sirgle-phase theories to } \\
\text { miltifhase flows (Poiseuille, } \\
\text { Covezte, rotating. Stability, } \\
\text { ete.) }\end{array}$ & $\begin{array}{l}\text { All future applications } \\
\text { where multiphese flows } \\
\text { are of potential useful- } \\
\text { ness }\end{array}$ & $\begin{array}{l}\text { Virtually all work done to date } \\
\text { has been emperical or semiempirical } \\
\text { in nature with specific need in } \\
\text { mind. Practically no directed } \\
\text { fundamental work has been under- } \\
\text { taken towards simpie extension of } \\
\text { single phase ideas to multiprase } \\
\text { fiov fields }\end{array}$ \\
\hline $\begin{array}{l}\text { Flow pattern extenston of } \\
\text { range }\end{array}$ & $\begin{array}{l}\text { Hixers, separators, liouid } \\
\text { metal mHD generators, geo- } \\
\text { thermal weills }\end{array}$ & $\begin{array}{l}\text { Improve efficiency of given systems } \\
\text { by artifically extending fiow } \\
\text { regime of enhanced or efficient } \\
\text { characteristics }\end{array}$ \\
\hline $\begin{array}{l}\text { Fiow pattem sizbility } \\
\text { with heat transfer }\end{array}$ & Condensors and reheaters & $\begin{array}{l}\text { Condensation-induced flow regime } \\
\text { collapse reduces hed transfer rate } \\
\text { and changes flow rates causing } \\
\text { oscillation }\end{array}$ \\
\hline $\begin{array}{l}\text { Flow patierr transition } \\
\text { and stability }\end{array}$ & AII multiphase flow systems & $\begin{array}{l}\text { All mess, momentum, and energy } \\
\text { exchange processes are governed by } \\
\text { the flow configurations wich govern } \\
\text { contact area and gradients }\end{array}$ \\
\hline Laminar and turbulent transport & $\begin{array}{l}\text { Injectors, jets, furnaces, } \\
\text { combustors }\end{array}$ & $\begin{array}{l}\text { Improved product design and } \\
\text { efficiency }\end{array}$ \\
\hline Modeling of turbulent transport & Coal utflization & $\begin{array}{l}\text { Developing improved systems for } \\
\text { processing and buming of coal }\end{array}$ \\
\hline Regions of laminar separation & $\begin{array}{l}\text { Aerodynamic hardware and } \\
\text { artificial organs }\end{array}$ & $\begin{array}{l}\text { To prevent failure by proper design } \\
\text { for safety and economic purposes }\end{array}$ \\
\hline Turbulent dispersion & Contactors & $\begin{array}{l}\text { Prevention of stable emulsion pro- } \\
\text { duction of radioactive waste }\end{array}$ \\
\hline $\begin{array}{l}\text { Turbulen: transport droplets } \\
\text { and particies }\end{array}$ & $\begin{array}{l}\text { Fuel injectors, soot trans- } \\
\text { port }\end{array}$ & $\begin{array}{l}\text { Dominant behavior in numerous pro- } \\
\text { cesses requiring energy utilization } \\
\text { optimization with littie knowledge } \\
\text { ovallable }\end{array}$ \\
\hline $\begin{array}{l}\text { Unsteady flow effects on } \\
\text { pressure. drop and heat trans- } \\
\text { fer in multi dimensional sys- } \\
\text { ters }\end{array}$ & $\begin{array}{l}\text { Particulate combustion, } \\
\text { heat exchangers }\end{array}$ & $\begin{array}{l}\text { Improve efficiency of carticulate } \\
\text { or heterogeneous combustion systems } \\
\text { and to improve knowiedge regarding } \\
\text { coal dust explosions }\end{array}$ \\
\hline Unsteady now effects & $\begin{array}{l}\text { Heat exchangers, high tem- } \\
\text { peratures multiphase devices } \\
\text { (combustors) }\end{array}$ & $\begin{array}{l}\text { For startup and shut dow predic- } \\
\text { tions as well as cyclic behavior } \\
\text { for energy system optimization. }\end{array}$ \\
\hline
\end{tabular}


Table 2.4 (Cont.): BASIC RESEARCH NEEDS INVENTORY

Fluid Dynamics and Thermal Processes, Fluid Flow

Primary Research Category: Multiphase Flows

Secondary Research Category: Eundamental Understanding

\begin{tabular}{|c|c|c|}
\hline Research Needed & Aoplication & Reason for Heed \\
\hline $\begin{array}{l}\text { Unsteady flow effects in } \\
\text { mulidirensional boundary } \\
\text { layers }\end{array}$ & $\begin{array}{l}\text { Compressors and other turbo- } \\
\text { machinery. }\end{array}$ & $\begin{array}{l}\text { Greatly imorove efficlency in } \\
\text { rotating machinery }\end{array}$ \\
\hline Unsteady flow effects & $\begin{array}{l}\text { Fusion reactor blankets and } \\
\text { confinement systers }\end{array}$ & $\begin{array}{l}\text { Improve design and optimize blanket } \\
\text { regions especially with pulsed } \\
\text { intermittent flows and energy } \\
\text { deposition in conlex gecietrice }\end{array}$ \\
\hline $\begin{array}{l}\text { Pressure drop in packed } \\
\text { beds }\end{array}$ & $\begin{array}{l}\text { Contactor, distillation } \\
\text { towers, gas absorption sys- } \\
\text { tems, cooling towers }\end{array}$ & $\begin{array}{l}\text { Imorove throughout rates thereby } \\
\text { reducing process eneray requirenents }\end{array}$ \\
\hline $\begin{array}{l}\text { Imoroved understanding of } \\
\text { pressure losses }\end{array}$ & $\begin{array}{l}\text { ofl wells, pipelines, geo- } \\
\text { thermal wells }\end{array}$ & $\begin{array}{l}\text { Inprove perforrance predictions, } \\
\text { increase yieid, inorove efficiency }\end{array}$ \\
\hline Packed bed behavior & Filters & $\begin{array}{l}\text { Improve efficiency of filters used } \\
\text { in containment or cnvironmental } \\
\text { protection areas }\end{array}$ \\
\hline $\begin{array}{l}\text { Motion of granular } \\
\text { materials }\end{array}$ & $\begin{array}{l}\text { Transport and processing } \\
\text { systems for cool, agri- } \\
\text { cultural products, ores. } \\
\text { chemicals. etc. }\end{array}$ & $\begin{array}{l}\text { Reduction in transport and process } \\
\text { costs and energy requirements }\end{array}$ \\
\hline $\begin{array}{l}\text { Fluid profile effects roids. } \\
\text { velocities. temperatures in } \\
\text { both steady and transient flows }\end{array}$ & $\begin{array}{l}\text { Generalized advanced energy } \\
\text { systers and components }\end{array}$ & $\begin{array}{l}\text { Need more detailed information for } \\
\text { accurate predictions and calculations } \\
\text { for imoroved efficiency, reduced } \\
\text { margins, reduced conservatism with } \\
\text { maintained safety }\end{array}$ \\
\hline $\begin{array}{l}\text { Multidimensional experimental } \\
\text { data }\end{array}$ & All multiphase equipment & $\begin{array}{l}\text { Improved understanding leading to } \\
\text { better computational methods for } \\
\text { improved design capability, } \\
\text { reduced conservatism, and betier } \\
\text { efficiency }\end{array}$ \\
\hline $\begin{array}{l}\text { Boundary layer and secondary } \\
\text { flows }\end{array}$ & Turbomachinery & Improved efficiency \\
\hline Heat transfer & $\begin{array}{l}\text { Nuclear reactors, heat ex- } \\
\text { changers, refrigeration sys- } \\
\text { tems, etc. }\end{array}$ & $\begin{array}{l}\text { Optimize equipment size relative to } \\
\text { duty }\end{array}$ \\
\hline Bubble dynamics & Contactors & $\begin{array}{l}\text { Design improvenents to imorove } \\
\text { efficiency in gas-1 lquid systems }\end{array}$ \\
\hline $\begin{array}{l}\text { Interactions with solid } \\
\text { structure from erosion or } \\
\text { damage standpoint }\end{array}$ & $\begin{array}{l}\text { All current and advanced } \\
\text { energy systers having two- } \\
\text { phase flow fields - coal } \\
\text { lqquefaction. geothermal } \\
\text { turbines. nuclear turuines, } \\
\text { fusion power plants, ete. }\end{array}$ & $\begin{array}{l}\text { Extension of equioment } l i f e \text { and im- } \\
\text { proved safety through elimination } \\
\text { or reduction of destruc:ive poten- } \\
\text { tial of multiohase flows due to } \\
\text { droplet erosion, cavitation, vi- } \\
\text { bration, deformation, etc. }\end{array}$ \\
\hline
\end{tabular}




\section{Table 2.5: BASIC RESEARCH NEEDS INVENTORY \\ Fluid Dynamics and Thermal Processes, Fluid Flow Primary Research Category: Multiphase Flows \\ Secondary Research Category: Interphase Transfers and Nonequilibrium}

\begin{tabular}{|c|c|c|}
\hline Researeh Heeded & Application & Reason for Heed \\
\hline $\begin{array}{l}\text { Improved understanding of incer- } \\
\text { facial transfer of mass, momen- } \\
\text { tum. and energy }\end{array}$ & $\begin{array}{l}\text { All advanced energy system } \\
\text { dpolication having multiphase } \\
\text { flow fielos }\end{array}$ & $\begin{array}{l}\text { Ceyelocment of advanced predictive } \\
\text { tools for develooment, design and } \\
\text { optimization }\end{array}$ \\
\hline $\begin{array}{l}\text { laproved understanding of tran- } \\
\text { sient and steady state transfer } \\
\text { mechanisms }\end{array}$ & $\begin{array}{l}\text { All advanced energy system } \\
\text { application having mulciphase } \\
\text { flow fields }\end{array}$ & $\begin{array}{l}\text { Development of advanced predictive } \\
\text { tools for development, cesign, and } \\
\text { optimization }\end{array}$ \\
\hline $\begin{array}{l}\text { lnoroved understanding of inter- } \\
\text { face formation, deformation. and } \\
\text { renewal mechanisms }\end{array}$ & $\begin{array}{l}\text { All advanced energy system } \\
\text { application having multiphase } \\
\text { flaw fields }\end{array}$ & $\begin{array}{l}\text { Prediction of ohenomena based on } \\
\text { interface transier laws will reguire } \\
\text { not only a understanding of the } \\
\text { transfer laws themselves but an } \\
\text { understanding of factors aifecting } \\
\text { the transier areas }\end{array}$ \\
\hline Holecular scale rodeling & $\begin{array}{l}\text { Many current and advanced } \\
\text { energy system divices }\end{array}$ & $\begin{array}{l}\text { Almost inoossible to predic: rates } \\
\text { in areas there safety or performance } \\
\text { are affecied }\end{array}$ \\
\hline $\begin{array}{l}\text { Improved understanding of } \\
\text { carttation phenomena }\end{array}$ & $\begin{array}{l}\text { High soeed multiphese flows, } \\
\text { propellar efficiency. flash- } \\
\text { ing impellor efficiency }\end{array}$ & $\begin{array}{l}\text { Improve efficiency, reduce erosion, } \\
\text { reduce noise in sys iens where the } \\
\text { potential for cavitation exists }\end{array}$ \\
\hline $\begin{array}{l}\text { Imoroved understanding of } \\
\text { cavitation phenomena }\end{array}$ & Pumps and components & $\begin{array}{l}\text { Reduce potential for flow induced } \\
\text { vibration and resultant darage }\end{array}$ \\
\hline $\begin{array}{l}\text { Improved understanding of } \\
\text { cavitation phenomend }\end{array}$ & Fow control devices & $\begin{array}{l}\text { Design optimization and reduce dariage } \\
\text { potential noise reduction }\end{array}$ \\
\hline $\begin{array}{l}\text { Inproved understand of cavitation } \\
\text { phenamena in entering passages }\end{array}$ & High speed pumps and turbines & $\begin{array}{l}\text { Oamage and noise reduction, imoroved } \\
\text { efficiency }\end{array}$ \\
\hline $\begin{array}{l}\text { Oirect contact condensation } \\
\text { limit of condensing rates }\end{array}$ & $\begin{array}{l}\text { Many current and advanced } \\
\text { energy system devices }\end{array}$ & $\begin{array}{l}\text { A high penaley is paid in terms of } \\
\text { size and efficiency due to our lack } \\
\text { of understanding }\end{array}$ \\
\hline $\begin{array}{l}\text { Vapor release in suddeniy } \\
\text { expanded systems }\end{array}$ & $\begin{array}{l}\text { Muclear reactor safety, } \\
\text { UNG transport }\end{array}$ & $\begin{array}{l}\text { Safety analysis of power generation } \\
\text { and LMG transport systems }\end{array}$ \\
\hline $\begin{array}{l}\text { Transient phase geometry } \\
\text { determination }\end{array}$ & Steam generators & $\begin{array}{l}\text { To determine potential for pocket } \\
\text { formation and race of pocket col- } \\
\text { lapse condensing induced wat.er } \\
\text { hammer }\end{array}$ \\
\hline $\begin{array}{l}\text { Particulate or oroplet } \\
\text { continuum coupling }\end{array}$ & $\begin{array}{l}\text { Power generation systern, } \\
\text { polution treatient systems, } \\
\text { gasification processes, coal } \\
\text { transport. ete. }\end{array}$ & $\begin{array}{l}\text { Imorove efficiency of particulate or } \\
\text { droplet transport and combustion } \\
\text { systems, morove or el iminate } \\
\text { polutants }\end{array}$ \\
\hline $\begin{array}{l}\text { Lstablishment, maintenance } \\
\text { and bolling in thin filso }\end{array}$ & $\begin{array}{l}\text { oref, waste heat, recovery } \\
\text { systens, low potential trans- } \\
\text { fer device }\end{array}$ & $\begin{array}{l}\text { Very high heat transfer rates ray } \\
\text { be obtained with thin films result- } \\
\text { ing in large improvements in effi- } \\
\text { cency but mechanisms are not well } \\
\text { unders tood }\end{array}$ \\
\hline
\end{tabular}


Table 2.6: BASIC RESEARCH NEEDS INVENTORY

Fluid Dynamics and Thermal Processes, Fluid Flow

Primary Research Category: Multiphase Flows

a) SECONOARY RESEARCH CATEGORY - MULIOIMEMSIONAL ANO ORIEMTATIONAL EFFECTS

\begin{tabular}{|c|c|c|}
\hline Research Heeded & Apolication & Reason for leed \\
\hline $\begin{array}{l}\text { Fundamental analysis and data } \\
\text { in general internal flaw sys- } \\
\text { tems as diffuses, bends. } \\
\text { around obstructions, etc. }\end{array}$ & $\begin{array}{l}\text { General multiphase fluid } \\
\text { flaw systems }\end{array}$ & $\begin{array}{l}\text { Information lacking for future } \\
\text { developments in all areas where } \\
\text { multidimensional fields must be } \\
\text { considered }\end{array}$ \\
\hline $\begin{array}{l}\text { General multidimensional } \\
\text { behavior in laminar and } \\
\text { turbulent flows }\end{array}$ & $\begin{array}{l}\text { All advanced multiphase } \\
\text { flow systems }\end{array}$ & $\begin{array}{l}\text { Advanced energy doolications designs } \\
\text { need methods for assessinent of effi- } \\
\text { ciency and optimization }\end{array}$ \\
\hline $\begin{array}{l}\text { Flow mixing due to strong } \\
\text { and weak cross flows }\end{array}$ & $\begin{array}{l}\text { Many multiphase flow } \\
\text { systems }\end{array}$ & $\begin{array}{l}\text { Little is known regarding mora cem- } \\
\text { plicated aspects of multipnase sys- } \\
\text { tems beyond single gearetries sucn } \\
\text { as round tubes and annuli }\end{array}$ \\
\hline $\begin{array}{l}\text { General multidimensional } \\
\text { model ing in turbulent fows } \\
\text { Including general stability } \\
\text { criteria }\end{array}$ & $\begin{array}{l}\text { Almost all advanced energy } \\
\text { sysiems and components in- } \\
\text { eluding heat exchangers. } \\
\text { fusion systems. OTEC. et. }\end{array}$ & No information available \\
\hline $\begin{array}{l}\text { Inside blades and passages, } \\
\text { mitidinensional flow flelds, } \\
\text { branches } \\
\text { Relative velocity and phase } \\
\text { distribution in horizontal } \\
\text { and inclined ducts }\end{array}$ & $\begin{array}{l}\text { Two-phase turbomachinery } \\
\text { Nuclear reactor systems }\end{array}$ & $\begin{array}{l}\text { Advanced energy application designs } \\
\text { need methods for dssessment of ef- } \\
\text { ficiency and optimization } \\
\text { Yirtually no infomation available }\end{array}$ \\
\hline $\begin{array}{l}\text { Fundamental anaiysis and data } \\
\text { in general intermal flow sys- } \\
\text { tems as diffuses, bends, } \\
\text { around obstructions, ete. }\end{array}$ & $\begin{array}{l}\text { General multiphase fluid } \\
\text { flow systems }\end{array}$ & $\begin{array}{l}\text { Information lacking for future } \\
\text { developments in all areas where } \\
\text { multidimensional fields must be } \\
\text { considered }\end{array}$ \\
\hline $\begin{array}{l}\text { Fow mixing due to strong } \\
\text { and weak cross flows }\end{array}$ & $\begin{array}{l}\text { Many multiphase flow } \\
\text { systers }\end{array}$ & $\begin{array}{l}\text { Little is known regarding more } \\
\text { complicated aspects of mul tionase } \\
\text { systems beyond simole geomatries } \\
\text { such as round tutes and annuli }\end{array}$ \\
\hline $\begin{array}{l}\text { General multidirensional } \\
\text { modeling in iurtulent flows } \\
\text { including general stability } \\
\text { critaria }\end{array}$ & $\begin{array}{l}\text { Aimost all advanced energy } \\
\text { systems and componenes in- } \\
\text { cluding heat exchangers, } \\
\text { fusion systems. OTEC. etc. }\end{array}$ & No information available \\
\hline $\begin{array}{l}\text { Relative velocity and phase } \\
\text { distribution in horizontal } \\
\text { and inclined ducts }\end{array}$ & Nuclear reactor systems & Virtually no information availabie \\
\hline $\begin{array}{l}\text { Develop theory and data in } \\
\text { rotating flows }\end{array}$ & Adyanced steam turbines & $\begin{array}{l}\text { Two-phase turbines appear aterac- } \\
\text { tive for use in advanced energy } \\
\text { conversion systers suen as solar } \\
\text { waste heat or autamotive, seo- } \\
\text { thermal, and rarine power systems }\end{array}$ \\
\hline $\begin{array}{l}\text { Steady and unsteady flow } \\
\text { behavior in blades and } \\
\text { passages }\end{array}$ & Turbomachinery, pumps & $\begin{array}{l}\text { No information dvailable for design } \\
\text { of advanced multiphase equipment }\end{array}$ \\
\hline
\end{tabular}


Table 2.6 (Cont.): BASIC RESEARCH NEEDS INVENTORY

Fluid Dynamics and Thermal Processes, Fluid Flow

Primary Research Category: Multiphase Flows

a) SECONOARY RESEARCH CATEGORY - MULTIDIMENSIOHAL AND ORIENTRTIONAL EFFECTS

\begin{tabular}{|c|c|c|}
\hline Research Heeded & Application & Reason for Need \\
\hline $\begin{array}{l}\text { Steady and unsteady flows } \\
\text { in orffices. entrances, exits, } \\
\text { branches }\end{array}$ & $\begin{array}{l}\text { Art interdal multiphase sys- } \\
\text { tems - refrigeration. air } \\
\text { conditioning, turbomachinery } \\
\text { nuclear reactor accicent } \\
\text { andysis }\end{array}$ & $\begin{array}{l}\text { Little or no information is avall- } \\
\text { able to enable accurate designs. } \\
\text { development, or odtimization cal- } \\
\text { culations to be undertaken }\end{array}$ \\
\hline $\begin{array}{l}\text { Theories for flashing flows } \\
\text { through valves and orifices }\end{array}$ & $\begin{array}{l}\text { Nuclear reactor systems - } \\
\text { other two-phase systems }\end{array}$ & $\begin{array}{l}\text { For design detemination of back } \\
\text { pressures and stresses in piping } \\
\text { systens. }\end{array}$ \\
\hline $\begin{array}{l}\text { Movement of droplet fields } \\
\text { through nozzles }\end{array}$ & $\begin{array}{l}\text { Geothermal power recovery } \\
\text { systens }\end{array}$ & $\begin{array}{l}\text { Design of advanced two-phase flow } \\
\text { turbines }\end{array}$ \\
\hline $\begin{array}{l}\text { Heltidimensional particulate } \\
\text { and granular flows }\end{array}$ & $\begin{array}{l}\text { Pneumatic or slurry trans- } \\
\text { port systems, blood flows. } \\
\text { spray systems }\end{array}$ & $\begin{array}{l}\text { Improve design capabilities in areas } \\
\text { where particle or granule trajec- } \\
\text { tones are important especially for } \\
\text { spray cooling }\end{array}$ \\
\hline $\begin{array}{l}\text { Fows around tubes and } \\
\text { baffles }\end{array}$ & Heat exchangers & $\begin{array}{l}\text { Hethod currently used are largely } \\
\text { empirical. Significant improve- } \\
\text { ments in efficiency may result fram } \\
\text { better understanding }\end{array}$ \\
\hline $\begin{array}{l}\text { Three-dimensiond flows } \\
\text { with shocks }\end{array}$ & $\begin{array}{l}\text { Advanced propulsion sys - } \\
\text { terms }\end{array}$ & $\begin{array}{l}\text { Improve existing methodology for } \\
\text { cesign and development to achieve } \\
\text { improved efficiency }\end{array}$ \\
\hline $\begin{array}{l}\text { Develop two-phase "Reynoids" } \\
\text { flow whe thods }\end{array}$ & Two-phase bearings & $\begin{array}{l}\text { Little information available which } \\
\text { will allow development of multi- } \\
\text { phase bearings to eliminate com- } \\
\text { plicated and costly external and } \\
\text { separated iubrication systems for } \\
\text { turbines }\end{array}$ \\
\hline
\end{tabular}

b) SECONDARY RESEARCH CATEGORY - COMPUTATIONAL METHODS

\begin{tabular}{|c|c|c|}
\hline Research Needed & Application & Reason for Heed \\
\hline $\begin{array}{l}\text { General multidimensional } \\
\text { behavior in laminar and } \\
\text { turbulent flows }\end{array}$ & $\begin{array}{l}\text { All advanced multiphase flow } \\
\text { systems }\end{array}$ & $\begin{array}{l}\text { idvanced energy application designs } \\
\text { need methods for assessment of } \\
\text { efficiency and optimization }\end{array}$ \\
\hline $\begin{array}{l}\text { Inside blades and passages, } \\
\text { multidimensional flow fields. } \\
\text { branches }\end{array}$ & Two-phase turbomachinery & $\begin{array}{l}\text { Advanced energy application designs } \\
\text { need methods for assessment of } \\
\text { efficiency and optimization }\end{array}$ \\
\hline $\begin{array}{l}\text { Around tubes, plates, and } \\
\text { biffles }\end{array}$ & $\begin{array}{l}\text { Heat exchangers, air } \\
\text { cleaners, etc. }\end{array}$ & $\begin{array}{l}\text { Improved design methods, reduce cost } \\
\text { due to elimination of experiments }\end{array}$ \\
\hline
\end{tabular}


Table 2.7: BASIC RESEARCH NEEDS INVENTORY

Fluid Dynamics and Thermal Processes, Fluid Flow

Primary Research Category: Multiphase Fiows

a) SECONDARY RESEARCH CATEgORY - MISCELLALIEOUS MEEDS

\begin{tabular}{|c|c|c|}
\hline Research Needed & ADDlication & Reas on for Heed \\
\hline $\begin{array}{l}\text { Pressure drop, concentration, } \\
\text { ear, abrasion relationships } \\
\text { in siurries } \\
\text { Optimize mixture and particle } \\
\text { size in coal slurries } \\
\text { study effects of liquid or } \\
\text { particulate ingacts on } \\
\text { materials } \\
\text { Cavitation-corrosion inter- } \\
\text { actions }\end{array}$ & $\begin{array}{l}\text { Spray systens, contustors, } \\
\text { filters, nuclear reactor } \\
\text { systems, :Ho generators, } \\
\text { transport systems } \\
\text { Coal transport and other } \\
\text { particuiate or granular } \\
\text { slurry systems } \\
\text { Coal transport } \\
\text { All multiphase applica- } \\
\text { tions esp. rotating ma- } \\
\text { chinery } \\
\text { Rotating equipment. } \\
\text { raives, orifices }\end{array}$ & $\begin{array}{l}\text { Behavior from size and irajectory } \\
\text { standpoint is not well known and. } \\
\text { therefore, ddvanced system develop- } \\
\text { ment and optimization is difficult. } \\
\text { de-entrainment of liquid droos on } \\
\text { structure is important in emergency } \\
\text { cooling considerations } \\
\text { Improved efficiency and structural } \\
\text { integrity of such systems } \\
\text { Minimize losses in particulate } \\
\text { transport systems } \\
\text { Equipment life extension and safety } \\
\text { improvements } \\
\text { Improve life and safety of such } \\
\text { equipment }\end{array}$ \\
\hline b) SECONOARY & RESEARCH CATEGORY - BOOY FORCE & EFFECTS \\
\hline Research Needed & Application & Reason for Need \\
\hline $\begin{array}{l}\text { Pulsed magnetic field } \\
\text { effects }\end{array}$ & $\begin{array}{l}\text { Liquid metal MHO, ceal- } \\
\text { fired plasma MOO } \\
\text { Fuston power systens }\end{array}$ & $\begin{array}{l}\text { Performance of advanced w0 gen- } \\
\text { erators is critical to the overall } \\
\text { cycle efficiencies and depends } \\
\text { heavily on such interactio.ls } \\
\text { Properly design and optimize fusion } \\
\text { blankets and maçnetic and irertial } \\
\text { confinement systems }\end{array}$ \\
\hline $\begin{array}{l}\text { Centrifugal separation } \\
\text { effects } \\
\text { Electrostatic field } \\
\text { effects }\end{array}$ & $\begin{array}{l}\text { Turborachinery and rotating } \\
\text { instrumentation } \\
\text { Electrostatic precepitates }\end{array}$ & $\begin{array}{l}\text { Design and optimization of advanced } \\
\text { energy systems components - reduced } \\
\text { stress on turbomachinery blades } \\
\text { improve efficiency of particulate } \\
\text { removal systems }\end{array}$ \\
\hline
\end{tabular}


Table 2.8: BASIC RESEARCH INVENTORY

Fluid Dynamics and Thermal Processes, Fluid Flow Primary Research Category: Fluid-Structure Interactions

\begin{tabular}{|c|c|c|}
\hline Research Needed & Application & Reason for Heed \\
\hline $\begin{array}{l}\text { - Mean effects } \\
\text { - Instantaneous local effects } \\
\text { - Integrated effects }\end{array}$ & $\begin{array}{l}\text { Design of buildangs, large } \\
\text { structures. Bridges. solar- } \\
\text { collectors, power towers. } \\
\text { wind turbine supports ojec } \\
\text { pipes and support structures }\end{array}$ & $\begin{array}{l}\text { Proper designs, earthauake energy } \\
\text { conservation. prevention of fallures } \\
\text { ind domsoges io collector ficlos and } \\
\text { wind turbines. Placement and design } \\
\text { of cold water pipe in ortec }\end{array}$ \\
\hline $\begin{array}{l}\text { brasd baste research } \\
\text { in now separtion. re. } \\
\text { attachment, vortex shedding } \\
\text { and flutd structure inter- } \\
\text { actions. Flow over tube } \\
\text { bundies and tn nuclear } \\
\text { reactor cores }\end{array}$ & $\begin{array}{l}\text { resign of hest exchanges. } \\
\text { nuclear reactors, turbines, } \\
\text { rousing machinery }\end{array}$ & $\begin{array}{l}\text { Hogher efficiencies and lower cost } \\
\text { in hed exchange equirment. better } \\
\text { rotacing mochinerg, safer nuclear } \\
\text { reactors }\end{array}$ \\
\hline
\end{tabular}

Table 2.10: BASIC RESEARCH NEEDS INVENTORY

Fluid Dynamics and Thermal Processes, Fluid Flow

Primary Research Category: Biological, Geologicai, and Environmental Eluid Elow

\begin{tabular}{|c|c|c|}
\hline Research Needed & Apolication & Reason for lleed \\
\hline $\begin{array}{l}\text { Basic understanding of flow } \\
\text { ohenomena in porous media } \\
\text { including pressure drop, and } \\
\text { heat transfer }\end{array}$ & $\begin{array}{l}\text { Oil recovery (secondary) } \\
\text { flitraticn clean up of oil } \\
\text { spills, geothermal heat re- } \\
\text { covery, thermal insulation }\end{array}$ & $\begin{array}{l}\text { Not enough information is ayaliasle, } \\
\text { little possibility ior using ba:d } \\
\text { for design. no verification }\end{array}$ \\
\hline $\begin{array}{l}\text { Determine mechanism of pro- } \\
\text { cesses involving fouling of } \\
\text { hest exchangers especially } \\
\text { in arine environments }\end{array}$ & $\begin{array}{l}\text { Improve hest exchanger per- } \\
\text { formance for OTEC apolica- } \\
\text { tion }\end{array}$ & $\begin{array}{l}\text { Economic feasidility of closed cycle } \\
\text { OTEC depends on size of hedt ex- } \\
\text { changers. Must size them correctly }\end{array}$ \\
\hline $\begin{array}{l}\text { Basic studies of now and } \\
\text { stability of stratified } \\
\text { nutd with body forces. } \\
\text { Experinental verification on } \\
\text { large scale }\end{array}$ & $\begin{array}{l}\text { Solar ponds atnospheric } \\
\text { phenomena inversion layers } \\
\text { geophysical fluid mechanics }\end{array}$ & $\begin{array}{l}\text { Improved design, control of insiabi- } \\
\text { lities or detivation of instabilities } \\
\text { to oreak up inversion layars }\end{array}$ \\
\hline $\begin{array}{l}\text { Mon-kewtonian flow in } \\
\text { caplliaries }\end{array}$ & Biood flow & Medical \\
\hline
\end{tabular}


Table 2.11: BASIC RESEARCH NEEDS INVENTORY

Fluid Dynamics and Thermal Processes, Fluid Flows

Primary Research Category: Facilities and Instrumentation Secondary Research Category: Instrumentation.

\begin{tabular}{|c|c|c|}
\hline Research lleeded & Appiteation & Reason for Heed \\
\hline $\begin{array}{l}\text { Develoo remote field veloc- } \\
\text { ity sensors and flow visu- } \\
\text { dization techniques }\end{array}$ & $\begin{array}{c}\text { Turbomachines, Dumps, } \\
\text { large fluid machinery } \\
\text { - }\end{array}$ & $\begin{array}{l}\text { It ts now extremely difficult io } \\
\text { visualize and medsure flow fields } \\
\text { that are indecessible and thus to } \\
\text { improve understanding of motion and } \\
\text { losses in such situdtions }\end{array}$ \\
\hline $\begin{array}{l}\text { Develop remote particle } \\
\text { or droplet sensing and } \\
\text { sizine techniques }\end{array}$ & $\begin{array}{l}\text { Ali particulate and } \\
\text { slurry systers }\end{array}$ & $\begin{array}{l}\text { Improve data base upon which under- } \\
\text { standing and design ootimization of } \\
\text { failure energy systems must be odsed }\end{array}$ \\
\hline $\begin{array}{l}\text { Develop remote bubble } \\
\text { velocity and sizing } \\
\text { methods }\end{array}$ & $\begin{array}{l}\text { All multiphase downs } \\
\text { in advanced energy } \\
\text { systems }\end{array}$ & $\begin{array}{l}\text { Improve data base upon which under- } \\
\text { standing and design ootimization of } \\
\text { fatlure energy systems must te based }\end{array}$ \\
\hline $\begin{array}{l}\text { Develop local ohase } \\
\text { volune fraction and } \\
\text { velocity rejsuring } \\
\text { systers for internediate } \\
\text { and high speed flow }\end{array}$ & $\begin{array}{l}\text { All advanced energy sys- } \\
\text { tem comoonents utilizing } \\
\text { mul tiphase flow fields }\end{array}$ & $\begin{array}{l}\text { llo me thods currently exist for ace- } \\
\text { quately measuring ohase velocities } \\
\text { doove } 1-2 \mathrm{~m} / \mathrm{s} \text {. Almost all flom sys- } \\
\text { tems have higher sieeds. This infor- } \\
\text { mation is desoerately neeted ior at- } \\
\text { vanced development methods }\end{array}$ \\
\hline $\begin{array}{l}\text { Dereiop inexpensive sen- } \\
\text { sors for consurer use }\end{array}$ & All consumer devices & $\begin{array}{l}\text { For measurement and cantrol of flow } \\
\text { temperature, yalve, mass, heat trans- } \\
\text { fer, etc. of devices on the consuner } \\
\text { level to improve comsurer product } \\
\text { efficiency }\end{array}$ \\
\hline Develop dam flow nonitor & $\begin{array}{l}\text { Ground water storage sys. } \\
\text { tens }\end{array}$ & $\begin{array}{l}\text { Present techniques are cumbersone, } \\
\text { expensive, time constining, and not } \\
\text { particularly useful }\end{array}$ \\
\hline $\begin{array}{l}\text { Development of various in- } \\
\text { struments for extrene envi- } \\
\text { ronments (gressure, tem- } \\
\text { perature, oynamics) }\end{array}$ & $\begin{array}{l}\text { Advanced energy conver- } \\
\text { sion systems, plasina MHO } \\
\text { generators, advanced nu- } \\
\text { clear reactor safety } \\
\text { studies, gas turbine } \\
\text { studies }\end{array}$ & $\begin{array}{l}\text { Cata on behavior of materials under } \\
\text { extreme conditions are dimos: non- } \\
\text { existant. Yet super cesigr drid ra- } \\
\text { liable operation of dovanced sysiens } \\
\text { requires such data }\end{array}$ \\
\hline $\begin{array}{l}\text { Develop iriexpensive, port- } \\
\text { able, reliable laser anemo- } \\
\text { meter }\end{array}$ & General flow measurement & $\begin{array}{l}\text { A cheap portzole Laser anemenser } \\
\text { would be a powerful : ool in sany } \\
\text { areas of fluid mechanics }\end{array}$ \\
\hline $\begin{array}{l}\text { Process and reaction moni- } \\
\text { tors - improvement }\end{array}$ & $\begin{array}{l}\text { General chemical and } \\
\text { ehermal processes }\end{array}$ & 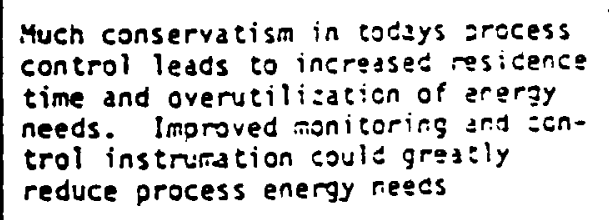 \\
\hline $\begin{array}{l}\text { Transient and unsteady flow } \\
\text { and pressure measurement }\end{array}$ & Tubomachinery & 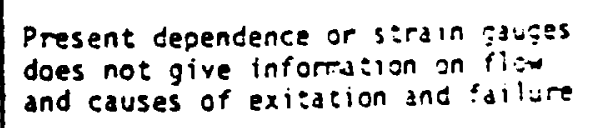 \\
\hline $\begin{array}{l}\text { Develop interphase trans- } \\
\text { port measuring devices }\end{array}$ & $\begin{array}{l}\text { All multiphase flaws } \\
\text { and flow systems }\end{array}$ & $\begin{array}{l}\text { Advanced predictive teols are relyirg } \\
\text { more and more on inierpise i-jester } \\
\text { descriptions out lit:le esta exis: :0 } \\
\text { quantify suen descriptions }\end{array}$ \\
\hline
\end{tabular}




\section{Table 2.11 (Cont.): BASIC RESEARCH NEEDS INVENTORY}

Fluid Dynamics and Thermal Processes, Fluid Flow

Primary Research Category: Eacilities and Instrumertation Secoriary Research caregory: Instrumentation

\begin{tabular}{|c|c|c|}
\hline Research needed & Application & Reason for Need \\
\hline $\begin{array}{l}\text { Develop improved relocity } \\
\text { meesuring devices for dif- } \\
\text { ficult environments }\end{array}$ & Basic fluid flow studies & $\begin{array}{l}\text { Lov's or hot wires are accurate but } \\
\text { not useful in opagae or corrosive/ } \\
\text { erosive environments (such a high } \\
\text { pressure/temperature water) }\end{array}$ \\
\hline $\begin{array}{l}\text { Devices for measuring flow } \\
\text { phencrena in rotating pas- } \\
\text { soges transonic conditions }\end{array}$ & Turbomachinery research & $\begin{array}{l}\text { improved instrunentation is a key } \\
\text { link in improving understanding for } \\
\text { development of flow models and ac- } \\
\text { curate prediction techniques for im- } \\
\text { proved perforiance and optimization } \\
\text { in advanced energy systems compo- } \\
\text { nents }\end{array}$ \\
\hline $\begin{array}{l}\text { Devices for measuring comoo- } \\
\text { nents and phiese fiow rates in } \\
\text { multiphase flows } \\
\qquad\end{array}$ & $\begin{array}{l}\text { All multiphese flow sys- } \\
\text { tems and components }\end{array}$ & $\begin{array}{l}\text { None currently exist that are reli- } \\
\text { able but the most balance in steady } \\
\text { and transient flows is a fundamental } \\
\text { basis for comparison of predictive } \\
\text { techniques with experimental results }\end{array}$ \\
\hline $\begin{array}{l}\text { Particulate or droplet } \\
\text { velocity and size classi- } \\
\text { fication methods }\end{array}$ & $\begin{array}{l}\text { All dispersed particulate } \\
\text { and droplet flows }\end{array}$ & $\begin{array}{l}\text { Oniy rudinentary methods currently } \\
\text { exist but much research is needed } \\
\text { in these areas }\end{array}$ \\
\hline
\end{tabular}

Table 2.12: BASIC RESEARCH NEEDS INVENTORY

Fluid Dynamics and Thermal Processes, Fluid Flow Primary Research Category: Facilities and Instrumentation Secondary Research Category: Iacilities

\begin{tabular}{|c|c|c|}
\hline Research Heeded & ADplication & Reason for Need \\
\hline $\begin{array}{l}\text { General, multipurpose research } \\
\text { faciliay for basic studies in } \\
\text { multiptiase steady and unsieady } \\
\text { nows }\end{array}$ & $\begin{array}{l}\text { Improved undersianding of } \\
\text { multipnase flow Deridvior }\end{array}$ & $\begin{array}{l}\text { Develop inproved predictive tools } \\
\text { for develocment, design, and cDti- } \\
\text { mization of advanced energy systems }\end{array}$ \\
\hline $\begin{array}{l}\text { Research facility for high } \\
\text { temperzture, hign pressure } \\
\text { studies for fussion studies }\end{array}$ & $\begin{array}{l}\text { Development of fussion } \\
\text { bianket desions }\end{array}$ & $\begin{array}{l}\text { No flexible facility is available } \\
\text { for such studies }\end{array}$ \\
\hline $\begin{array}{l}\text { Research facility for use in } \\
\text { aerospace, meterological, and } \\
\text { combustion researeh }\end{array}$ & General studies & $\begin{array}{l}\text { A national facility does not cur- } \\
\text { rently exist and is needed for ad- } \\
\text { vanced studies supporting meteoro- } \\
\text { logical and combusion process } \\
\text { studies }\end{array}$ \\
\hline $\begin{array}{l}\text { Research facility for oeneral } \\
\text { multiphase flow studies }\end{array}$ & $\begin{array}{l}\text { Advanced energy system } \\
\text { development }\end{array}$ & $\begin{array}{l}\text { Improve data base for fundamental } \\
\text { understanding of multiphase flows }\end{array}$ \\
\hline $\begin{array}{l}\text { Calibration facility for } \\
\text { single and multiphese gas. } \\
\text { liquid and/or particulate } \\
\text { nows }\end{array}$ & $\begin{array}{l}\text { Advanced energy system } \\
\text { development }\end{array}$ & $\begin{array}{l}\text { Providing of national standards } \\
\text { facility for new instrumentation } \\
\text { development is crucial for imoroved } \\
\text { measurement techniques in all fluid } \\
\text { flow areas. None currentiy exists }\end{array}$ \\
\hline $\begin{array}{l}\text { Uitre high Reynolds number } \\
\text { now facility }\end{array}$ & $\begin{array}{l}\text { Advanced energy conver- } \\
\text { sion system such as OTEC }\end{array}$ & $\begin{array}{l}\text { Deterpine forces on biuff bodies at } \\
\text { Re>10 for OTEC and other offshore } \\
\text { studles }\end{array}$ \\
\hline
\end{tabular}


The major priorities appear to be ordered as follows:

- Multiphase and Multicomponent Flows

- Application to and experimental verification of extensions of single-phase flow theory to multi-phase, multicomponent turbulent flows.

- Detailed studies of nucleation phenomena and of interfacial structure and transfers. Th is should be done in simple and multidimensional geometries and free field flows. Objective determination of flow regimes and of phase and/or component spacetime distributions should be undertaken in laminar and turbulent flows.

- Fundamental studies regarding effects of scaling laws building on knowledge gained in the previously defined studies.

- Fluid Structure Interactions

- Research should be undertaken in energy-related problems of flow-induced vibrations due to both periodic and stochastic loadings. Such loadings may be due to such effects as vortex shedding or turbulent interactions in both free fields and boundary layers. Attention should be given to both coupled and uncoupled interactions. Areas of concern include, but are not limited to, tubes in heat exchangers and blades in turbines and compressors.

- Fluid/structural coupling in cases of both impulsive and aperiodic loadings should also be investigated. Such situations include condensation-induced water hamer, and transient decompressive reactions, for instance.

- Shear, Mixing, and Reactive Flow Effects

- In spite of current and continuous emphas is in boundary layer research, the difficult problems dealing with real systems still exist. The area of separation and reattachment remains unresolved and appears to be of central importance affecting performance, lifet ime, and safety of turbomachinery, among others. Significant gains in pre-service energy utilization appear possible with improved understanding which could be gained through such research.

- Fundamental studies into the flow patterns about road vehicles are needed and can be of great benefit. These flows involve three-dimensional bluff bodies, in extremely close proximity to a ground plane, with strong vortical wakes. Both wind-tunnel and analytical modeling studies are recommended.

- Research needed in internal flow with chemical reactions leading to a detailed understanding of the coupled processes which enable the development of more efficient, cleaner combustion systems. In th is category, particular emphas is 
should be placed on advanded analys is techn iques and instrumentation to study internal combustion automotive engines and others. 
Table 3.2 CRITICAL RESEARCH AREAS AND SPECIFIC TASKS

PARTICLE REMOVAL FROM LIQUIDS

- Particle removal from synthetic liquid fuels

- Extension of sedimentation theory to a wide range of particle sizes and to hindered settling regimes

- In situ particle size measurements at high temperatures and pressures

- Surface properties of particles in synthetic liquid fuels

- Electrically-induced agglomerates of suspended fission products

- Electrical enhancement of liquid filtration

- Concentration of solids in coal liquics by distillation

TRACE POLLUTANT REMOVAL

- Determination of adsorbent selectivity and regeneration methods for hydrocarbon removal from water

- Selective precipitation of trace heavy metal species

- Mechanisms of electrostatic precipitation

SEPARATIONS IN HOT GASES

- Regenerable mixed oxide sorbents for use in hot gases

- Particle removal from hot gases

RESOURCE BENEFICIATION

- Mechanisms of coal flotation

- High gradient magnetic separation of pyrites from coal

\section{CRYOGENIC SEPARATIONS}

- Mechanisms in cryocondensation pumping of hydrogen isotopes

- Studies of cryosorption separation of synthetic gas mixtures

REDUCTION OF ENERGY LOSSES IN SEPARATION PROCESSES

- Systems analysis for minimizing energy losses in Distillation systems 


\section{DIFFERENTIAL SOLUBILITY}

- Vapor-liquid equilibrium data for synthetic fuels

- Transport data for drying

- Asphaltene crystallization

- Supercritical extraction

\section{SURFACE-SEIECTIVE PROCESSES}

- Effects of surface adsorption on particle stability (both aqueous and nonaqueous environments)

- Mechanisms of solvent deashing

\section{IMPOSED GRADIENTS}

- Mechanisms of electrostatic coalescence

- New concepts for continuous electrophoresis

- Theory of density gradient centrifugal separation

- Transport mechanisms in continuous centrifuges

- New concepts for self-cleaning continuous centrifuges

\section{BARRIERS}

- Septum Filtration

- Investigate new concepts for continuous filtration

- Study new filtration media particularly for small particles

- Investigate the use of biological membranes for selective transport

- Study selective membrane permeability

BED FIITRATION

- Study particle interactions in fixed and fluidized beds including the effects of particle shape

- Investigate methods of enhancing particle capture

- Develop a theory to describe the inital part of the filtration curve where the filtration equation is inadequate for cake filtration

- Investigate filter precoats that are most suitable for non-aqueous systems

- Relate permeability and compressibility of filter cakes to particie characterization parameters

- Couple the study of particle penetration into substrates and cyclic methods to restore the original surface

- Investigate methods of displacing valuable product from the interstices and surfaces of precoats and cakes 


$$
\text { Table } 3.3 \text { (Cont.) }
$$

\section{SUPPORTIVE RESEARCH}

- Create a clearinghouse for information on novel separation techniques

- Investigate surface charges of particulates in nonaqueous environments

- Investigate instrumentation concepts for on-line, dispersed particulate characterization particularly at high temperatures 
The following pages from the report summarize the major specific R\&D needs and the research gaps they address.

\subsubsection{Nature of Work}

- Theoretical studies of appropriate cycles and suitable fluids.

- Experimental verification of heat transfer coefficient correlations.

- Experimental testing of chemical stability and corrosion.

- Design studies of suitable machinery.

\subsubsection{Research Gaps}

- Research is needed to improve our understanding of the basic phenomena involved in high flux heat transfer and prevention of burn-out.

- Knowledge of how materials perform in high heat flux systems must be developed. Improved materials may be needed.

\subsubsection{Research Needs}

- Development of an inexpensive low-energy method of producing crude oxygen or enriched air. Possible methods should be surveyed in planning the research. Possible techniques might make use of absorption, diffusion, and para-magnetic separation.

\subsubsection{Research Needs}

Superior processes are needed. Fundamental research might be performed in response to surveys of promising methods. Means that should be considered are: novel batteries; processes that produce a chemical fuel from waste energy which is, in time, used in a fuel cell to produce electricity during peak periods; suitable reversible chemical reactions where heat is absorbed with an endothermic reaction at the surplus heat location and the reaction is reversed at a distant location or different time period with the release of heat; and methods of storage of thermal energy by freezing (crystallization) and melting of high freezing point materials.

\subsubsection{Research Needs}

- Means to achieve higher gas convective heat transfer coefficients without increased energy expenditure of high-intensity turbulence. Possible methods include:

- Surface roughness

- Boundary layer thinning techniques

- Vibration

- Electrostatic fields 
- Focusing of heat transfer to achieve selective transfer, through the use of electrostatic or magnetic fields

\subsubsection{Research Needs}

- A better fundamental understanding of the effects of turbulence on combustion, especially of solid fuels, flame shaping, effects of combustion variables on flame heat transfer, and on pollution

- Development of furnace design methodology, especially with regard to heat transfer, to make furnace design more of a science than an art and to reduce dependence on empirical design of limited applicability.

- Develop scaling methods for fluid bed coal combustors and kinetics of coal combustion at high pressures

\subsubsection{Gaps}

Fundamental research directed toward determining lateral running rates of particles in the combustion bed, and combustion rates of fluid particles offers the possibility of predicting the required spacing of fuel feed points, and hence the number of feed points required.

Mixing rates are one aspect of the problem of scaling the mechanical behavior of fluidized beds, and fundamental research might be directed to the problem of developing reliable scaling methods.

Combustion rates could be studied separately on a relatively small scale. The spacing of fuel feed points is then determined by the requirement that lateral running times be short compared with combustion times.

For the basic research program, it is recommended that reactions and turbulence models be chosen when detailed experimental verification of resulting models can be obtained. Research on instrument techniques is al so appropriate.

Hydrocarbon oxidation under conditions where rates are such that incomplete oxidation is a problem is suggested as a high priority starting point. Practical problem areas are lean combustion, hydrocarbon destruction in the freeboard space of fluidized bed combustion and hydrocarbon emissions in transportation power plants.

- Mechanics and chemistry of char consumption and the interaction with ash under both combustion and gasification conditions

- Relative rates of thermal and catalytic reactions in hydrogenation catalyst particles

- Reactions and transport processes and solid state transformations in limestone particles under combustion, gasification and coal pyrolys is conditions

- Hydrogen/hydrocarbon reactions in slurry reactors

- Solid/hydrocarbon interactions in fluidized bed pyrolys is 
- Localized temperature fluctuations in fluidized bed combustion and gasifiers as related to ash and agglomeration

- Reactions of nitrogen and sulfur species in fluidized bed combustion

- Electrode reaction mechanisms including gas nucleation and evolution, dissolution and precipitation reactions and solid transformations

- Transport phenomena such as ionic transport in membranes and solid electrolytes and heat and mass transfer in porous electrodes

- Understanding and improvement of electrode catalyses with emphasis on aging processes in oxygen, hydrogen and chlorine electrodes, and electrocatalysis 
- Report No. 24

I. Georgia Institute of Technology. Energy Conservation in the Paper and Allied Products Industry, Phase I. DOE/CS/4098-T1. Department of Energy, Washington, D.C., October 1979.

II. Technical and/or End-Use Focus

Paper and Allied Products Industry

III. Types of Information Provided

1. No mention of end use data was made.

2. Fairly detailed energy savings analysis of two specific technologies was given.

3. No estimate was made of times to commercialization but the study did discuss barriers to implementation, such as manufacturability and cost. (Machnozzle, high feedstock temperatures).

4. No review of existing research was made.

5. No methodology for ident ifying research opportunities.

IV. R\&D Opportunities

1. Higher feedstock temperatures - allows for reducted viscosity and surface tension (and increased drainage reduces pumping losses) also means less heat would be needed in the drying section

- Energy Savings

$20 \times 10^{6}$ (tons of paper and board)

( 0.4 ton \& 0.4 tons) (steam saved) $=16 \times 10^{6}$ tons of dryer steam saved

$16 \times 10_{12}^{6}$ tons *2000 1b/ton * $1000 \mathrm{Btu} / \mathrm{Hb}=$

$32 \times 10^{12}$ Btu saved/yr

- Immediately available for commercialization except for cost problems

- Higher temperatures create problems:

- corrosion

- formation

- scales, deposits

- machine room temperature/insulation of pipes

- etc.

- References attached

2. Machnozzle - aids in the dewatering (or drying) part of paper making. The paper sheet laid down requires much less drying. $\mathrm{pg}$. 2,3 
- Energy Savings

$98,0001 \mathrm{bm} /$ day steam saved

$98,0001 \mathrm{bm} /$ day 350 days $/ \mathrm{yr} * 1000 \mathrm{Btu} / 1 \mathrm{~b}=3.5 \times 10^{10}$

Btu/yr

-- VERY ROUGH ESTIMATE -- 100 plants $=3.5 \times 10^{12}$

Btu/yr

- Nozzle available now

- cost possible problem

- plugging

- operability/down time

- References attached

V. Critical Summary

The detail was good in this report. However although the title sounds good, the discussion is completely limited to the two technologies discussed above. Most of the report discusses experiments done with the Machnozzle. Information given seemed good.

VI. Comments

Rev iewed by SGA. 
- Report No. 25

I. Gordian Associates. IEA Steel R\&D Report, Final Report. AL0-5076-TI. May 31, 1979.

II. Technical and/or End-Use Focus

Cooperative international research concerning the steel industry is the focus of this report.

III. Types of Information Provided

1. No review of end-use energy data was made.

2. No estimates of energy savings from research were made.

3. Rather than specify a time to commercialization, a funding period and expected effort were given for each of the research suggestions.

4. Existing programs were not mentioned.

5. In this study, the methodology consisted of steel representatives from the participating IEA countries being solicited for suggestions.

IV. R\&D Opportunities

All of the research and development suggestions were summarized in Appendix B.

A. Surface Inspection

(1) U1trasonic Methods

- development time - 2 yrs.

(2) Eddy Current Methods

- development time - 2 yrs.

(3) Optical \& Other Methods

- development time - 2 yrs.

(4) Development Program (selection of the most promising methods)

- funding period - 2 yrs.

B. Surface Conditioning

Hot Grinding

C. Heat Recovery

(1) Fluid Bed Cooling

- development time - 4 yrs. 
(2) High Temperature Heat Exchangers and Recuperators

(3) Dry Coke Quenching

(4) Ceramic Heat Wheel

(5) Scrap Preheating

(6) Heat Recovery from Slag

(7) Low Temperature Heat Recovery

D. Energy Conversion \& Combustion

(1) Continuous Gasification of Coal

- devel opment time - 2 yrs.

(2) Coal Injection with Plasma Burner

- development time - $1 \mathrm{yr}$.

(3) Pyrolysis of Low Grade Coals

(4) Heavy Fuel 0 il Combustion

(5) Blue Flame Burner

E. Material Properties

(1) Continuous Casting Slurries

(2) Hot Working \& Heat Treatment

- development time - 4 yrs.

V. Critical Summary

Since this document describes planned activities in an end use area, the justification of needs has apparantly been settled. Whether the suggested projects came about from a formal assessment of needs or a consensus of industrial contacts is not clear, but the latter is implied.

Member countries do not support all the activities but on $1 y$ those of national interest. For example, the U.S. is only planned to support the surface inspection development program, high temperature heat exchangers and recuperators, dry coke quenching, and scoop preheating.

This document fulfills the requirement of an activities report, but does not attempt to explain why the countries are supporting the projects. As a result, the report is very short, 5 pages of text.

VI. Comments

Reviewed by GJH. 
- Report №. 26

I. Grey, Jerry, Sutton, George W. and Zlotnick, Martin, "Fuel Conservation and Applied Research". Science 200, No. 4338, April 14, 1978, pp. 135-142.

II. Technical and/or End-Use Focus

The real focus of this paper is on the need for and the nature of applied research. In end-use terms, it focuses on automobiles.

III. Types of Information Provided

1. A very nice breakdown of where energy is used in an automobile was presented.

2. Estimates were given for specific improvements in terms of their impact on auto fuel use and national fuel use.

3. No estimates of times to commercialization were made.

4. No review of existing research programs was made.

5. The methodology used is to see that the research opportunities are selected to address major losses in automobile.

IV. R\&D Opportunities *

(1) Low air draft design (33\% reduction in auto drag) (p. 140). Current drag coefficients are 0.45 to 0.55 . Experts estimate 0.25 to 0.3 as a practical goal. Many gaps exist in the engineering information related to ground effect, influence of wheels and wheel wells, effects of intakes and cooling ducts, effects of flow control devices, such as dams, vanes, spoilers, flaps, and vents, and basic airflow over auto bodies. Increased understanding of three dimensional flows is necessary for improved aerodynamic performance.

- Could result in $8 \%$ reduction in auto energy consumption, $1 \%$ national reduction.

- References

Program Plan Report for Applied Research in Road Vehicles (TRW Energy Systems Planning Div., ERDA Contract E-1-76-C-03-1182, Task 17, 2a, July 1977.

(2) Piston ring-cylinder friction reduction (reduction of 25\%) (p. 140). $12 \%$ of mechanical work of engine is lost in this region because of friction and blow-by at this seal.

- Could result in $2.4 \%$ savings in automobile energy and $0.4 \%$ of total national energy $(70,000$ barrels of $0 i 1$ per day).

- References

0. Pinkus, D. F.. Wilcock, Strategy for Efficient Energy Utilization Through Tribology (Research Committee on Lubrication of the American Society of Mechanical Engineers, New York, 1977). 
(3) Adiabatic Diesel Engine (efficiency increase of 60\%) (p. 140).

- Could result in $40 \%$ reduction in auto energy consumption, $8 \%$ reduction in nati onal ener gy consumption.

- Ref erences

Same as item (1).

(4) Continuously Variable Transmission with Conventional Engine (p. 140) Need to achieve high efficiency and durability. The lubricant of the traction drive is a key component of developing the CVT.

- Could result in $20 \%$ reduction in auto ener gy consumption, $4 \%$ reduction in total national energy consumption.

- References

Same as items (1) and (2).

(5) Continuously Variable Transmission with Regenerative Braking (p. 140).

- Could result in $35 \%$ reduction in auto energy, $7 \%$ reduction in total energy.

- References:

Same as items (1) and (2).

(6) Improved Engine and Driveline Lubricants (p. 140). $25 \%$ reduction in engine friction. Low viscosity lubricants offer promise but are expensive and exhibit behavioral anomalies.

- Could result in $5 \%$ reduction in auto energy consumption, $1 \%$ reduction in total national energy consumption.

- References

Same as item (2).

(7) Low Drag Tires (50\% reduction in rolling resistance) (p. 140).

- Could result in $13 \%$ reduction in auto ener gy consumption, $2.5 \%$ reduction in national energy consumption.

- References

Same as item (1).

(8) Diesel Engines, Stirling Cycle, Gas Turbine (p. 140).

- Could result in $30 \%$ reduction in auto energy, $6 \%$ reduction in national energy.

- References: 
Same as item (1).

(9) Improved 0tto Cycle (p. 140).

- Could result in $25 \%$ reduction in auto energy, $5 \%$ reduction in national e ner gy.

- References:

Same as item (1).

(10) Valve Resizing (reduction of 60\% in pumping loss) (p. 140).

- Could result in $13 \%$ reduction in auto ener gy, $2.5 \%$ reduction in national energy.

- Ref erences:

Same as item (1).

(11) Xyl an Coating (halves valve friction) (p. 140).

- Could result in $15 \%$ reduction in auto energy, $3 \%$ of national total.

- References:

Same as items (1) and (2).

(12) Idle-off System (auts idle loss) (p. 140).

- Could result in $12 \%$ reduction in auto energy, $2.4 \%$ reduction in national total.

- References:

Same as item (1).

*It should be recognized that the savings from the various technologies discussed are not additive. The paper calculates total savings for various combinations of technologies (p. 141). Basically the maximum reduction results from combination of low air drag design, CVT with regenerative braking, low drag tires, and a diesel, stirling cycle, or gas turbine engine (assuming any are $30 \%$ more efficient than conventional engi nes), which increases the efficiency over current automobiles by 67 percent without reducing weight or size of the vehicles.

V. Critical Summary

Although this paper is very narrowly restricted to energy conservation in automobiles, it provides a very good model for how to go about identifying R\&D opportunities. The breakdown of where energy goes in a conventional automobile gives the analyst a valuable checklist of possible types of conservation techologies and highlights areas where major improvements are possible. A 
potential improvement on this approach would be to look at the efficiency of each component of the device or process in 2nd 1 aw terms as opposed to 1st 1 aw. However, even if such an improvement is made, one must take care in using the approach of identifying R\&D opportunities in response to a breakdown of e ner gy flows in a conventional process or device. The results may tend to be unimaginative because the approach does not encourage investigation of radically different means with which to achieve the same end use. It must be remembered that the end-use service is transportation, not automobiles. Thus, communications may be a substitute for some auto travel. Special attention needs to be given to radical approaches, al though it is not clear how this can be done systematically. The approach given in this paper provides a good beginning for developing an R\&D needs identification methodology.

VI. Comments

Reviewed by WJH. 
- Report No. 27

I. Hollander, Jack M. Basic Research Needs in Energy Conservation. LBL, 99939. Lawrence Berkeley Laboratory, University of California, October 1979.

II. Technical and/or End-Use Focus

This report discussed needs in the following end use areas: industrial processes, combustion systems, energy storage, conversion, and transmission, buildings, transportation, thermodynamics and system studies, and environmental impacts.

III. Types of Information Provided

1. Little end-use data were used. The report cites the need for more specific and thorough end-use data.

2. No estimates of energy savings from research were made.

3. Time to commercialization was not discussed, though the division between short and long term research was.

4. No review of existing research programs was made.

5. No methodology for identifying research opportunities was given; however, the report seemed to point to the need for a more comprehensive methodology.

IV. R\&D Opportunities

INDUSTRIAL PROCESSES

A. Basic materials processing -(paper, stee 1$)$

B. Basic mechanical studies

(1) Friction, lubrication

(2) Control of fluid flow

(3) Separation processes (osmosis, absorbtion)

(4) Heat transfer (at surfaces, boiling, two phase flow)

(5) Study of sensors (automatic control)

C. Process Control

(1) Catalytic Mechanisms

Relating to less severe and more selective reaction conditions

for coal liquification and gasification.

(2) In-situ Processing

Fluid flow in porous media of low void fraction.

(3) Control and Dynamic Interaction of Processes 
(4) Effective Use of Heat Exchange Through Control

D. Direct Coal Use

Fuel gas desulphurization must be improved

E. Processes

Fundamental chemical or mass transport mechanisms

F. Separation

In chemical and food processing, $80 \%$ of the energy use is attributed to distillation, evaporation, and drying.

G. Material Containing Devices

(1) Gas to gas heat exchangers.

(2) Vapor liquid contacting devices often over designed.

H. Electrochemical Processes

(1) Electrode geometry

(2) Surface Potential

(3) Boundary-Layer Control

(4) Non-aqueous Ionizing Media

(5) Corrosion Resistant Material

COMBUSTION SYSTEMS

A. Diesel Engines

(1) Soot

(2) In-situ on-line monitors to characterize particle emissions, combustion nuclei and gases.

B. Coal

(1) Understanding of chemical and physical phenomenon of caol combustion, gasification, and liquefaction.

(2) Rates and mechanisms releasing heat and pollution.

(3) Coupling of heat release and pollutant chemistry to turbulent field mechanisms.

(4) Flammability, flamespeed, toxicity.

(5) New diagnostic instruments to facilitate in identifying high temperature kinetics and turbulent fluid mechanics. 
ENERGY STORAGE, CONVERSION, AND TRANSMISSION

(1) Long distance power transmisison lines.

(2) Hydrogen storage, transmission, and use.

(3) Basic electro- and thermo-chemical studies for batteries.

BUILDINGS

(1) Heat pumps.

(2) Better hot/cold storage.

(3) Community heating.

(4) Controlling solar insolation through windows.

- Optical shutter with a variable solar transmission.

- Optical active materials

For example, photothermochromic and electrochromic, liquid crystal, colloidal suspensions, absorbtion edge shifts, solid state phase transformation, electrolytic precipitation of metals.

TRANSPORTATION

(1) Fundamental properties of fluids which might be used in advanced engines.

(2) Air drag.

(3) Telecommunication.

THERMODYNAMICS AND SYSTEM STUDIES

(1) Second law efficiency analysis

ENVIRONMENTAL IMPACTS OF ENERGY CONSERVATION STRATEGIES

(1) Ventilation systems

(2) Heat exchangers to tranfer both latent and sensible heat.

(3) Pollutant release from insulation.

(4) Formaldehyde release from particle board/plywood.

(5) Pollutant release from new building techniques.

- Nitric acid under pressure.

(6) Health effects of fiberglass

(7) Radon gas release from concrete bricks. 


\section{Critical Summary}

The thrust of the paper appears to be a justification of governmnet sponsored technical, social, and environmental research related to energy conservation. The author's examples of research needs thus take the form of an overview of the breadth of potential rather than an exhaustive list. The examples provided are a mix of general and specific activities. However, since research activities are emphasized rather than specific needs for energy research in certain areas, an assessment of energy savings in each area is not attempted.

The report was very readable and provides a good introduction to the breadth of possible energy conservation research efforts. For a 25 page paper, the author was amazingly thorough in his treatment. In general, a good summary.

V. Comments

Reviewed by GJH 


\section{REFERENCES}

1. Nationai Academy of Sclences. Report of the Committee on Nuclear and Alternative Energy Systems (CONAES). Chapter 2. NAS_NRC, Washington, D.C., 1979 (In press).

2. National Academy of Sclences. Report of the CONAES Panel on Energy Demand and Conservation. 1979 (In press).

3. Brooks, H. and Hollander, J. M. "United States Energy Alternatives to 2010 and Beyond: The CONAES Study." Annual Review of Energy, 4, 1979.

4. Schipper, L. "Another Look at Energy Conservation," Papers and Proceedings, American Economic Review. May, 1979.

5. National Academy of Sciences. Report of the CONAES Panel on Energy Supply and Delivery (1979) (In press).

6. J. H. Gibbons, "Long Term Research Opportunities," in Conservation and Public Policy, J. C. Sawhill, ed., Prentice-Ha1l, Inc. Englewood Cliffs; N. J. (1979).

7. W. R. Grimes et al, "Assessment of Basic Research Needs and Priorities in Support of Fossil Energy," Preliminary Draft (April 1979).

8. R. S. H. Mah (ed.), "Innovative Design Techniques for Energy-Efficient Processes," National Science Foundation Workshop Report, March 1975.

9. G. T. Rochelle, "Process Synthesis and Innovation in FGE," Report FP463-ST, Electric Power Research Inst \&tute, Palo Alto, July 1977.

10. T. W. Mix, J. S. Dweck, M. Weinberg and R. C. Armstrong, "Energy Conservation in Distillation," Chem. Eng. Prog., 74, (4) 49 (1979).

11. S. G. Unger, "Energy Utilization in the Leading Energy-Consuming Food Processing Industrles," Eood Technology 29 (12), 33 (1975).

12. C. D. Hollowell et al, "Chemical and Physical Characteristics of Vehicle Emissions," Lawrence Berkeley Laboratory Report LBL-5214, p. 54 (1976).

13. Chin Fu Tsang, "A Review of Current Aquifer Thermal Energy Storage Projects," Lawrence Berkeley Laboratory Report LBL-9211, May 1979. See also: Proceedings of Workshop on Thermal Energy Storage in Aquifers, LBL-k431, CONF-7805140, May, 1978.

14. Some references on photochromic materials:

a. Schulman, J. H., Compton, W. D., "Color Centers in Solids," MacMillan, M. Y., 1962; 

b. Megla, G. R., Applied Optics, 5, 6 (June 1966).
c. Seitz, F., Reviews Mod. Physics, 23,4 (October 1951)

15. K. M. Friedman and R. M. Obermann, "Transportation and Telecommunications: The Energy Implications." Annual Review of Energy, 4 1979 (in press).

16. A. B. Lovins, "Soft Energy Technologies," Annual Review of Energy, 3 , p. 477 (1978).

17. C. C. Hollowell, J. V. Berk and G. W. Traynor, "Impact of Reduced Infiltration and Ventilation on Indoor Alr Quality in Residential Buildings," LBL-8470, EEB-Vent 78-6, November 1978; ASHRAE Journal, 1979 (in press).

18. R. J. Budnitz, J. V. Berk, C. C. Hollowell, W. W. Nazaroff, A. V. Nero, and A. H. Rosenfeld, "Human Disease from Radon Exposures: The Impact of Energy Conservation in Buildings," LBL-7809, EEB-Vent 78-5, August, 1978; Energy and Buildings, 1979 (in press).

19. I. Schipper and A. Lichtenberg, "Efficient Energy Use and Well Being: The Swedish Example," Sclence, Dec. 3, 1976, 194, 1001-1013.

20. A. Doernberg, Energy Use in Japan and the United States. BNL 50713, UC-95c. August 1977. Upton, New York: Brookhaven National Laboratory.

21. T. V. Long and L. Schipper, "Resource and Energy Substitution," Energy, No. 1, 1978, 3, 63-79.

22. Griffia, J. 1979. Energy Conservation in OECD Countries. Cambridge, Mass.: Ballantine Books.

23. National Academy of Sciences. Report of the CONAES Resource Group on "Consumption, Location, and Occupation Patterns." Washington, D. C. (1979). 
- Report No. 28

I. Johnson, R. M., "Tribology: Research and Development Needs in Advanced Energy Technology," HEDL-SA-1191, 1977.

II. Technical and/or End-Use Focus

The report is focused on advanced energy technologies (fossil, nuclear, solar, etc.) with strong emphasis on nuclear, and the LMFBR in particular.

III. Types of Information Provided

1. No review of energy end-use data was made.

2. No estimates of energy savings from research were made.

3. No times to commercialization were given.

4. The "ERDA National Friction, Wear, and Self-Welding Program" was discussed.

5. No methodology for identifying research opportunities was given.

IV. Research Opportunities Were Established in General Terms:

1. Characterize long-term stability materials in high temperature, harsh environments.

2. Develop knowledge of properties of wear resistant materials, especially at higher temperatures.

3. Standardize wear testing methods and materials.

4. Organize existing and future data to be of maximum design use.

5. Establish a Tribology Information Center.

6. Support a National Tribology Testing Center.

Specific data needs are:

1. Characterize the time-temperature effects on hard surfacing materials.

2. Correlate microstructures and materials properties with friction and wear behavior.

3. Establish a list of reference properties for wear technology related materials.

- For additional references, see attached sheet.

V. Critical Summary

This report appears to be moderately comprehensive and detailed for the narrow scope it addresses. Research needs were justified only in the most general terms, primarily on technical merit.

VI. Comments

Rev iewed by REW. 


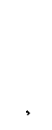


- $\quad$ Report No. 29

I. Klaus, E. E. "Energy Conservation in Road Transportation through Lubricant Technology," Lubrication Engineering. Vo1. 34.11, November 1978, pp. 611-617.

\section{Technical and/or End-Use Focus}

Discussion of end use was concentrated on automative applications in engines and transmissions.

III. Types of Information Provided

1. End-use energy consumption was reviewed.

2. Energy savings from research were estimated.

3. No est imates of times to commercialization were made.

4. Brief mentions of past technological advances were made in general to provide perspective, but no specifics were given.

5. Research opportunities were identified strictly by technical merit.

IV. Research Opportunities were Outlined in General Terms :

1. Improved understanding of the mechanics of boundary friction (sliding wear).

2. Improved understanding of chemistry of interactions among lubricant additives (compatibility and formulation techniques).

3. Improved understanding of relationships among viscosity, volatility, temperature, and wear.

4. Improved understanding of Non-Newtonian viscosity improvers.

5. Development of traction drive lubricant if this device is considered for implementation.

- Potential energy savings were estimated at $1 \%$ for improved viscometrics and $1 \%$ for improved boundary lubrication.

- For additional information; see attached references.

V. Critical Summary

This article gives an excellent and concise explanation of the technical and some nontechnical problems encountered in developing improved automatic lubricants. Items discussed ranged from the different types of lubrication occurring in various parts of the engine, to the base stocks required for new lubricant development. Of interest is the fact that viscometrics and boundary lubrication developments are independent of each other. Research needs were discussed in terms of technical advances required to achieve goals. Energy savings were quoted, but no details of the deviation of these estimates were provided.

VI. Comments

Good report for background reading (seven pages long).

Reviewed by REW. 


\section{REFERENCES}

1. Zolotnik, M., "Role of Tribology in ERDA's Mission and Programs," Tribology Workshop, February 1977, Washington, D.C.

2. Hays, D.F., "Gaspeth Sealing," Tribology Workshop, February 1977, Washington, D.C.

3. Pinkus, 0. and Wilcok, D. F., "Strategy for Energy Conservation through Tribology," 174 pages, The American Society of Mechanical Engineers, N.Y., 1977.

4. Haviland, M. L. and Davison, E. D., "Lubricant Viscosity Effects on Passenger Car Fuel Economy," SAE Trans., Paper 750675, 84 (1975).

5. Kanno, R., "The Adiabatic Diesel," Tribology Workshop, February 1977, Washington, D.C.

6. Stewart, R. M. and Selby, T.W., "The Rel ationship Between 0 il Viscosity and Engi ne Performance -- A Literature Search," pp. 1-19, ASTM STP 621, SAE Warrendale, Pennsylvania, 1977.

7. Stambaugh, R. L. and Kopko, R. J., "Behavior of Non-Newton ian Lubricants in High Shear Rate Applications," SAE Trans., Paper\#730487, 82 (1973).

8. Appeldoom, J. K., "The Present State of Lubrication and Its Relation to Rheolo gy," ASME Paper\#68-LKII -5, ASME-ASLE-ASTM Symposium on Lubrication and Lubricant Rheology, 1968.

9. Ambrose, H. A. and Taylor, J. E., "Wear, Scuffing and Spalling in Passenger Car Engines," SAE Trans., pp. 192-2a03, 63 (1955).

10. Wi11n, J.E. and Brett, P. S., "An Investigation into Piston Ring Scuffing During Running In," SAE Paper 750861, 1975.

11. Nutt, H. V., Lanen, E. W. and Edgar, J. A., "Effect of Surface Temperature on Wear of Diesel-Engi ne Cylinders and Piston Rings," SAE Trans., pp. $694-703,63(1955)$.

12. K1 aus, E. E. and Fenske, M. R., "Some Viscosity-Shear Characteristics of Lubricants," Lubr. Eng.., II, March-Apri1 (1955).

13. Stewart, R. M., Spohn, C. R. and Meyer, W. A. P.,, "Some Factors Contributing to Winter Hot Starting Difficulties in Automative Engines," SAE Trans., pp. 1453-65, 77 (1969).

14. Stewart, R. M., Spohn, C. R. and Meyer, W. A. P., "Influence of Lubricating 0 il Formulation on Winter Hot Starting Torque Requirement," SAE Trans., pp. $722-35,78$ (1970).

15. K1 aus, E. E., Tewksbury, E. JJ. and Fenske, M. R., "Preparation, Properties, and Some Applications of Super Refined Mineral 0 ils," ASLE Trans., 5, No. 1, pp. 115-25 (1962). 
16. Klaus, E. E. and Bieber, H. E., "Effect of Some Physical and Chemical Properties of Lubricants on Boundary Lubrication," ASLE Trans., 7 , pp. 1-10 (1964).

17. McMillan, M. I., "Engine $0 i 1 \mathrm{~V}$ iscosity Classifications -- Past, Present and Future," SAE Paper 770-73, pp. 21-32, ASTM STP 621, SAE, Warrendale, Pennsylvania, 1977.

18. So, B. Y., "Visosity-Pressure Correl ations for Liquid Mixtures," Ph.D. Thesis, The Pennsylvania Stae University, University Park, Pennsylvania, August 1975.

19. Dubois, G. B., Oovirk, F. W. and Wehe, R. L., NACA Contract No. NAW6197, Progress Report 9 (Revised), August 1953.

20. Anonymous, "Son ic Shear Stability of Polymer Containing 0ils," ASTM Test Method D2603-76, pp. 562-6, Annual Book of ASTM Standards, ASTM, Phil adelphia, Pennsylvania, 1976.

21. Klaus, E. E. and Jolie, R. M., "Effect of Polymer Structure on the Viscosity Properties of Polymer Solutions," ASME Paper No. 58-A-294, ASME, 1958.

22. Smalheer, C. V. and Smith, R. K., "Lubricant Additives," Lezius-Hiles Co., Cleveland, Ohio, 1967.

23. Hewko, L. 0., "Traction Drives," Tribology Workshop, February 1977, Washington, D.C. 

- Report №. 30

I. May, E. Kenneth, and Hooker, Douglas W. Reducing Fuel Usage Through Applications of Conservation and Solar Energy. SERI/TP-733-665, April 1980.

\section{Technical and/or End-Use Focus}

The focus was on the industrial end-use sector.

III. Types of Information Provided

1. Process heat demand in various temperature ranges as percentages of the total process heat demand for 1974 was graphed.

2. No direct energy savings were estimated, though examples of savings in a few plants were given.

3. No estimates of times to commercialization were given.

4. No review of existing research programs was made.

5. No methodology for ident ifying R\&D opportunities was given.

IV. R\&D Opportunities

(1) Less expensive heat exchangers operating at low differential temperatures ( $p .4)$

(2) Corrosion problems (p. 4)

V. Critical Summary

This is a very brief report describing the potential for solar energy in generating low temperature industrial process heat. The national potential was discussed first, then several case studies were described.

The report deals with the topic at a general level. Research and development needs are mentioned cursorily and conservation potential was not discussed thoroughiy.

This paper was delivered at the Western Plant Engineering Conference and the presentation was clearly flavored for this audience. The authors mention several times that plant management and plant supervisors were critical to the implementation and success of solar IPH. Increasing energy costs, a list of factors favoring solar IPH, and case studies were selected to be relevant for this audience.

VI. Comments

Reviewed by GJH. 
- Report No. 31

I. MITRE Corporation. An Agenda for Research and Development on End-Use Energy Conservation. Volumes I and II. Mtr-6577. McLean, VA, December 1973.

- Funded by Office of Energy R\&D Policy, National Science Foundation.

II. Technical and/or End-Use Focus

The main focus of this report is to recommend R\&D programs to enhance energy conservation at the point of use. It examines the

Residential/Commercial, Industrial, Agricultural, and Transportation sectors. However, because it is aimed at recommending budgets, the report gives a great deal of attention to non-technical R\&D, such as studies of incentives, etc.

III. Types of Information Provided

1. A review of old (1960-68) energy data was made.

2. Energy savings from research were estimated only in general terms, such as "better insulation reduced heating energy requirements by 18.6 ".

3. No estimates of times to commercialization for technologies were given.

4. No review of existing research programs was made.

5. The methodology used in this study is pretty much an "educated assessment" of the problem with the results presented as opinions rather than justifiable outcomes.

IV. R\&D Opportunities

(1) Develop a more efficient automobile engine (Stirling, Diesel, Rankine, DISC, Brayton) (p. III-76).

- Could save $15 \%$ of transportation fuel.

(2) Develop an improved transmission (e.g., continuously variable) (p. II I-76).

- Could save $10 \%$ of transportation fue 1 .

(3) Reduce Vehicle Drag (Aerodynamic and Rolling Resistance) (p. III$76)$.

- Could save $8-10 \%$ of transportation energy.

(4) Reduced Accessory Power (reduced capacity, constant speed drives) (p. II I-76).

- Could save $5 \%$ of transportation energy.

(5) Reduced Vehicle Weight (p. III-77).

- Could save $6 \%$ of transportation energy. 
(6) Develop High Performance Batteries for Electric and Hybrid Vehicles ( $p$. IV-18).

(7) Develop a Transportable Heat Engine Van capable of Delivering Steam and Refrigerant to Part-Time Food Processing Plants During Harvest. (p. II I-62).

(8) Develop Improved Fluidized Bed Combustors (p. II I-40).

- Increased efficiency of furnace and kiln operations for $30 \%$ to $50 \%$.

(9) Heat Pipes (p. III-40).

V. Critical Summary

This report is rather old (1973), and is therefore based on pre-embargo data. Thus, in 1980, many of the quantitative conclusions may no longer be accurate. However, the general tone of the report is quite contemporary and the conclusions are reasonable although not rigorous. In general, this is a good study for 1973 but has largely been displaced by other more recent studies.

VI. Comments

Reviewed by WJH. 
- Report No. 32

I. Office of Technology Assessment. Residential Energy Conservation. Vol. I. Office of Technology Assessment, Washington, D.C., 1978 est. (No date given).

II. Technical and/or End-Use Focus

Very Specific Focus on Residential (some commercial) Uses.

Parallel reports are currently being prepared by the same office for

Transportation and Industrial Energy Conservation.

III. Types of Information Provided

1. Very detailed review and summary of end-use data.

2. No estimates of energy savings were made, although some generalizations were made.

3. Times to commercialization were estimated for several technologies.

4. A brief review of existing research was made.

5. The study mentioned several times about having contacted manufacturers. Many of the opinions given seem to be from these contacts. This would seem to constitute some form of methodology.

IV. R\&D Opportunities (See Table 7s in Report)

3.0 Heating and Cooling Equipment

3.1 Direct Fossil-Fired Heating Equipment

3.2 $0 i 1$ and Gas Furnace Efficiency Improvements

- reduce burner firing rate (by $25 \%$ )

- boiler water temperature reduction $\left(35^{\circ} \mathrm{F}\right)$

- burner efficiency adjustment

- retention head burner

- vent damper

- stack heat reclaimer

- low input/variable firing rate burners

- ducting combustion air from outdoors

- modern high-efficiency burner-boiler

- blue flame burner-boiler

- outdoor boiler installation

- combustion air humidification

- water-oil emulsion

3.3 Advanced Fuel-Fired Equipment

- Pulse Combustion furnaces and boilers

- fuel-fired heat pumps

3.4 Electric Air-Conditioners and Heat Pumps

- more efficient compressors

- multiple compressors (enhance part-load efficiency) 
- improved heat exchangers

- more efficient motors

- automatic fan controls

- improved airflow

3.5 Gas-fired Heat Pumps and Air-Conditioners

- Absorpti on Air-Condi ti oners

- Absorption Heat Pumps

- Other gas fired heat pumps

- gas turbine

- Stirling engine

- diesel engines

- Rankine engines

4.0 Integrated App 1 i ances

4.1 Air condi ti oner/water heater

4.2 Furnace/water heater

4.3 Refrigerator/water heater

4.4 Drain water heat recovery

5.0 Controls and Distribution Systems

- controls for individual equipment (1ights, etc.)

- controls for space heating and cooling

6.0 Passive Solar Designs

- thermal storage

- indirect and direct gain

V. Critical Summary

The review was very comprehensive. Parts were sketchy, but it was meant to be a summary, not an exhaustive study. Technically it was sound. It did not attempt to justify R\&D needs, it merely assessed the current state.

VI. Comments

I felt it was by $f$ ar the most comprehensive summary of residential energy conservation I've read. It very accurately portrayed where current ener gy conservation potential exists.

Reviewed by SGH. 
- $\quad$ Report No. 33

I. Oppenheim, A. K. and F. J. Weinberg, "Combustion R\&D - Key to Our Energy Future", Astronautics and Aeronautics. November 1974, pp. 22-31.

II. Technical and/or End-Use Focus

Technical Focus - Combustion processes related to emissions and efficiency, principally in view of auto and aircraft engines.

III. Types of Information Provided

1. No energy end-use data were reviewed.

2. No estimate of energy savings was made.

3. Times to commercialization were not considered

4. Existing research programs (as of 1973) were mentioned and referenced.

5. No methodology for identifying R\&D opportunities was given.

IV. R\&D Opportunities (Given on Page 30)

(1) Experimental Investigators - facilities which should include:

- Molecular beams

- Shock tubes

- Explosion vessels

- Single pulse compression-expansion machines

- Flow combustion chambers

(2) Development of auxilliary apparatus and instruments.

(3) Theoretical and analytical studies.

(4) Hardware development testing.

(5) Evaluation.

V. Critical Summary

A good quick, well-referenced introduction to combustion R\&D. The exact needs, energy savings, pollution reduction are not given, but it is assumed that review of the 38 references would give a good "feel" for these things.

VI. Comments

Useful for idea collection for basic R\&D topics on combustion. Much sifting will be done before a good set of fundable projects is arrived at. Reviewed by WEG. 

- Report No. 34

I. Pinkus, 0. and Wilcock, A. F., "Strategy for Energy Conservation through Tribology, "Published by ASME, 1977.

II. Technical and/or End-Use Focus

This report discussed potential energy savings via tribology technology in the transportation, industrial, and utilities sectors. Important end-use applications identified were: automotive vehicles (engines, lubricants and transmissions), steam and gas turbines (bearings and seals), general industrial friction and wear, and heavy metal forming operations.

III. Types of Information Provided

1. Energy end-use data were reviewed in fair detail.

2. Energy savings were calculated.

3. Time to complete research was tabulated, but time for commercialization was estimated in passing in only a few cases.

4. Existing research programs were reviewed on ly in passing while discussing specific project objectives. No organized tabulation of existing research was given.

5. Project selection was based on five criteria: level of potential energy savings, technical feasibility, economic feasibility, response by industry and public, and national interest. Specific project areas were classified into "Recommended Projects" and "Study Panels" by the members of the workshop and advisory group.

IV. R\&D Opportunities

See attached sheet.

V. Critical Summary

This is in general a fairly comprehensive survey that is frequently referenced. Energy statistics are briefly reviewed in relation to tribology and are used in selecting specific projects to be recommended. Then background and supporting information is given in sufficient detail for each primary technical area considered, and potential energy savings are summarized. Finally, a detailed qualitative description is provided for each project recomended. The R\&D justification was established in part by opinion survey of technical experts. The weak points of the report appear to be the occasional unclear sources of reference energy savings data, and sometimes confusing computation or presentation of potential energy savings for specific projects. This is particularly evident in the areas of "general industrial friction and wear" and "metal procesing."

VI. Comments

Rev iewed by REW. 


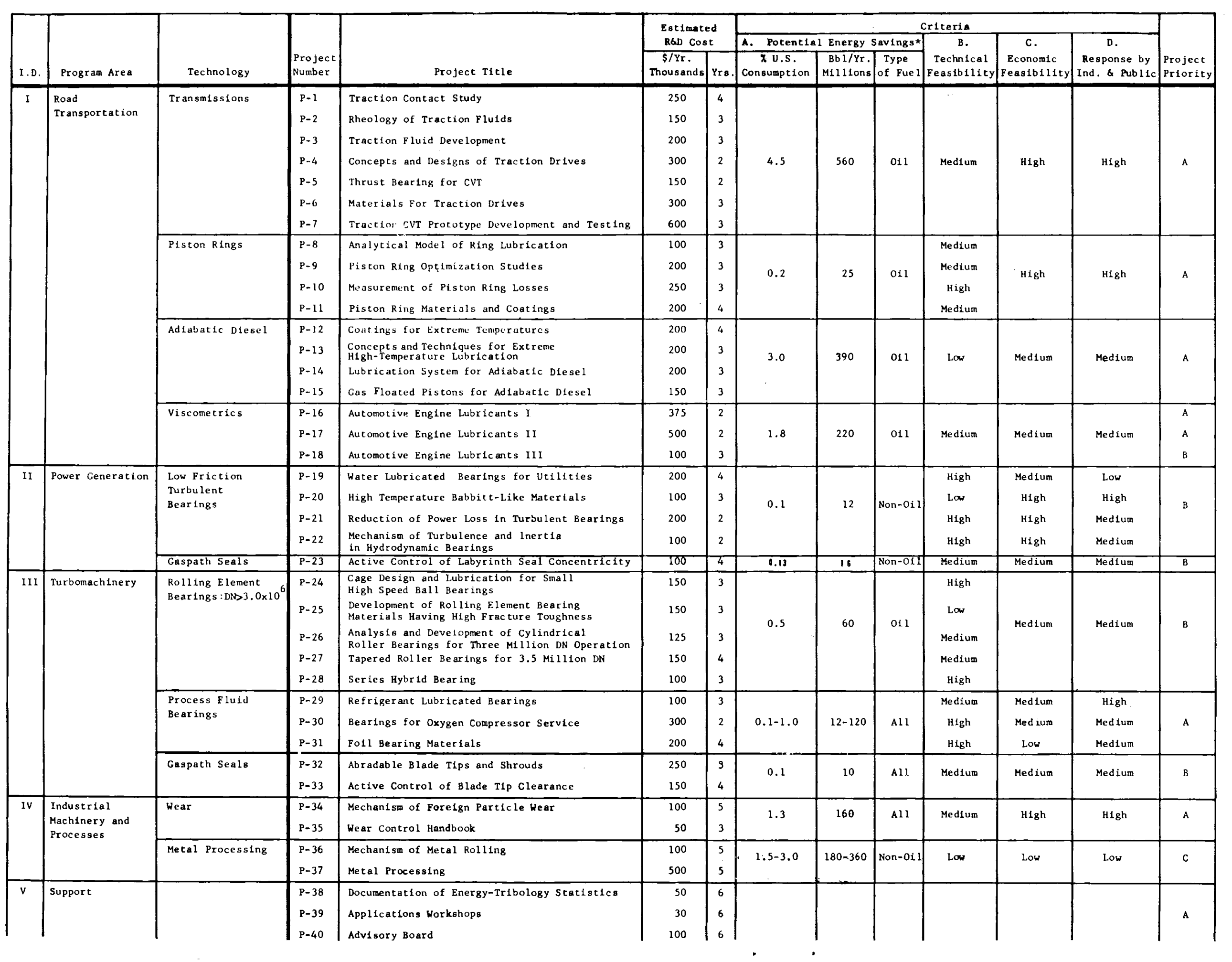




\section{A. REFERENCES}

1. Meyers, B., et al, "A Topping Cycle for Coal Fueled Electric Power Plants Using the Ceramic Helical Expander", paper presented at Symposium on Environment \& Energy Conservation, sponsored by EPA \& ERDA, September 1975 .

2. "Lubrication" Education and Research; A Report on the Present Position and Industry's Needs", Department of Education and Science, HMSO, London, G.B. 1966 .

3. "Tribologie" Bundesministerium fur Forschung und Technologie. Forschungsber1cht T76-38, Postfach 860880 , MUnchen 86, W. Germany, July, 1976.

4. Pinkus, 0., Tribology Workshop, February 7-9, 1977, Washington, D.C. (MTI, Latham, N.Y.)

5. Wilson, R.F., and Tierney, W.T., "Optimization of the Vehicle-Fuel-Refinery System", API 41st Mid-year Meeting, May 10-13, 1976, Los Angeles, Cal.

6. Zlotnick, M., "Role of Tribology In ERDA's Mission and Programs", Tribology Workshop, February 7-9, 1977, Wash1ngton, D. C. (ERDA, Washington, D. C.)

7. Hays, D.F., "Gaspath Sealing", Trlbology Workshop, February 7-9, 1977, Washington, D. C. (G.M. Research Labs., Warren, Mich.)

8. Tierney, W.T., Johnson, E.M., and Crawford, N.R., "Energy Conservation Optimization of the Vehicle-Fuel-Refinery System", SAE Paper 750673, Fuels \& Lubricants Meeting, June 3-5, 1975, Houston, Texas.

9. Rice, R., "Energy Efficiencies of the Transport System", Int. Aut. Engineers Congress, SAE, January 1973, Detro1t, Mich.

10. Pinkus, 0., Decker, 0., and Wilcock, D.F., "How to Save 5\% of Our Energy", Mechanical Engineering, September 1977.

11. "Energy Consumption In Manufacturing", by the Conference Board, Ballinger Publishing Co., Cambridge, Massachusetts, 1974.

12. Booser, E.R., "Fluid Film Bearings", Tribology Workshop, February 7-9, 1977, Washington, D. C. (General Electric Co., Schenectady, N.Y.)

13. Anderson, W.J., "Rolling Element Bearings", Tribology Workshop, February 7-9, 1977, Washington, D. C. (NASA-Lewis Res. Ctr., Cleveland, ohio.) 
14. Miller, D.R., "Traction Fluids", Tribology Workshop, February 7-9, 1977, Washington, D.C. (Monsanto Co., St. Louis, Mo.)

15. Hewko, L.0., "Traction Drives", Tribology Workshop, February 7-9, 1977, Washington, D. C. (New Departure, Sandusky, Ohio)

16. Lemanski, A.J., "R\&D Needs in Power Transmission Technology", Tribology Workshop, February 7-9, 1977, Washington, D. C. (Boeing Vertol Co., Philadelphia, Pa.)

17. Jost, H.P., "Economic Impact of Tribology", Mechanfcal Engineering, August 1975 .

18. Haviland, M.L., "Automotive Fuel Economy Gains Through Lubricatica Technology", Trłbology Workshop, February 7-9, 1977, Washington, D. C. (G.M. Research Labs, Warren, Mich.)

19. Kamo, R., "The Adiabatic Diesel", Tribology Workshop, February 7-9, 1977, Washington, D. C. (Cummins Engine Co., Columbus, Ind.)

20. DOD Industry Metal Chip Removal Conference, February 8-10, 1977, Daytona, Fla.

21. Seireg, A., University of Wisconstn, Madison, Wis., Oral Communfcation.

22. Johnson, R.N., "Research and Development Needs in Advanced Energy Technology" Tribology Workshop. February 7-9, 1977, Washington, D.C. (WestinghouseHanford Co., Richland, Washington) 
- $\quad$ Report No. 35

I. Resource Planning Associates. Implementation of Energy Conservation Technology in the Pulp and Paper Industry. Department of Energy, Washington, D.C., September 1980.

II. Technical and/or End-Use Focus

Pulp and Paper Industry - in general

III. Types of Information Provided

1. A brief overview of energy was presented (p. 12).

2. Energy savings were presented, ( $p .33,34, c .20, c .52)$.

3. Times to commercialization were given for technologies.

4. No review of existing research programs was made.

5. See attached pages for methodology used.

IV. R\&D Opportunities

General list: (see attachments)

Three technologies were looked at in detail:

A. Advanced air/fuel ratio control systems.

1. Automatic control of excess air to boilers by monitoring $\mathrm{CO}, \mathrm{O}_{2}, \mathrm{HC}$, and/or opacity. Controls were not justified when many of the boilers were installed years ago (with cheap fuel) see pg. 10.

2. See attached (up to $9 \times 10^{12}$ Btu total).

3. Available now.

4. None discussed.

5. None.

B. Heat recovery from paper dryers using heat wheels - involves the recovery of sensible heat from dryer exhaust air.

2. See attached (up to $22 \times 10^{12}$ Btu total).

3. Available now

4. None

5. None

C. Extended Slip Press

- removes more water from paper mechanically before going to

2. See attached (up to $32 \times 10^{12}$ Btu tota 1)

3. Available now

V. Criticality Summary

The study began very comprehensively by interviewing 33 companies for new technologies. However, the study was based on an agreement that the technologies must be available and influence the market significantly by 1985. Thus the long term ideas were out in the first pass. For the three main technologies looked at, the detail was amazing. Everything was considered. They even developed a program plan for implementation. It's unfortunate they didn't look at all of the ideas more closely. 
VI. Comments

They seem to be rather convinced on the necessity for government involvement in the near term projects.

Reviewed by SGH. 
Exhibit 8.1

Study Methodology

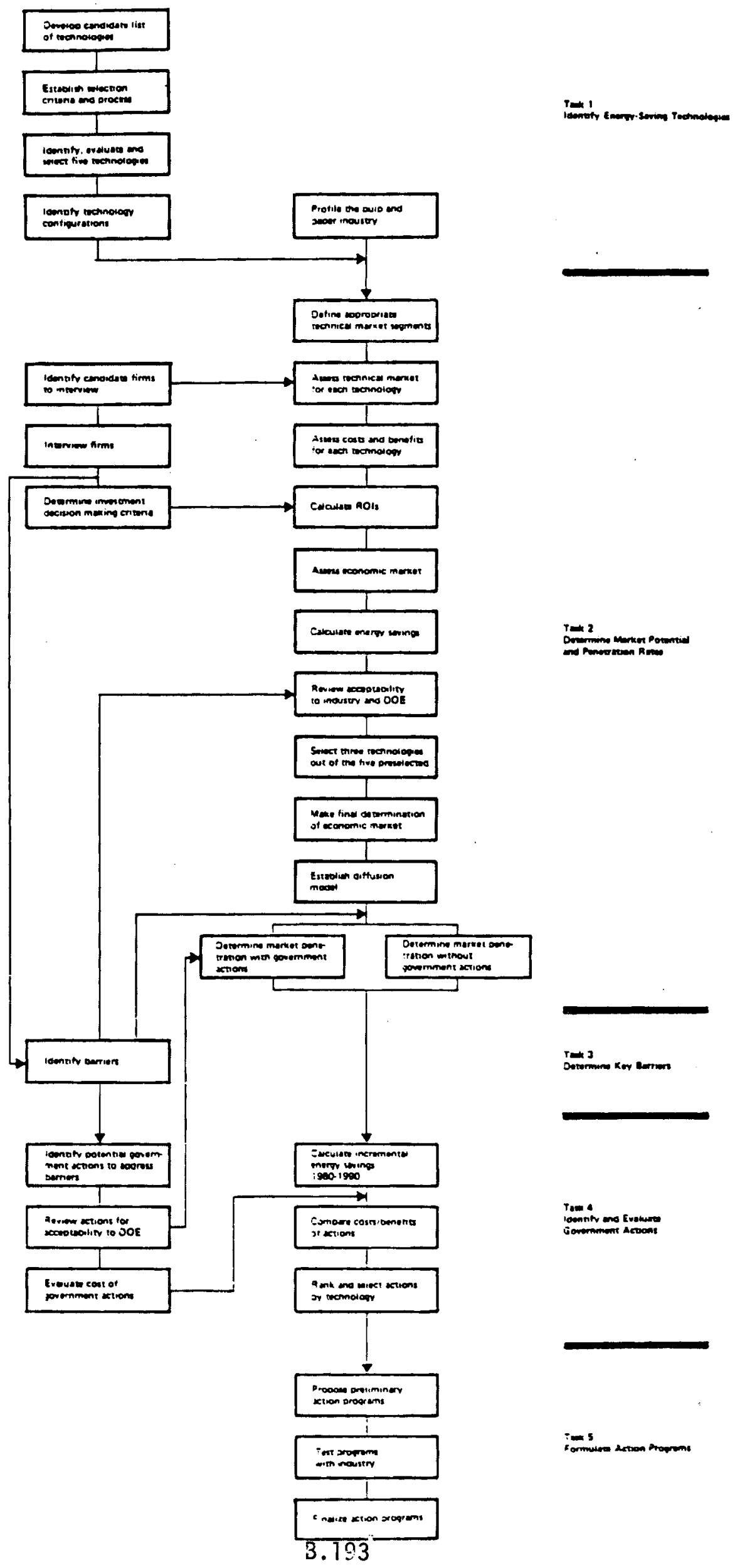




\section{Exhibit $\mathbf{B . 2}$}

\section{Results of Preliminary Screening of Technologies}

\begin{tabular}{|c|c|}
\hline Score & Technology \\
\hline 4.75 & Advanced air/fuel ratio controls \\
\hline 4.65 & Cogeneration \\
\hline 4.55 & Automatic contról bleaching \\
\hline 4.55 & Automatic control digester \\
\hline 4.55 & Automatic control recovery boiler \\
\hline 4.40 & Vapor compression \\
\hline 4.25 & Heat recovery from existing dryers \\
\hline 4.25 & Use of hot water from flue gas scrubbing to eliminate sieam usage in ine bleach plant \\
\hline 4.15 & Extended nip oress \\
\hline 4.05 & Corrosion-resistant economizers \\
\hline 4.00 & Hot water from flue gas scrubbing \\
\hline 3.95 & Bark and hog fuel preparation \\
\hline 3.90 & Increased end product moisture \\
\hline 3.85 & Paper pressing \\
\hline 3.75 & Steam distillation of methanol \\
\hline 3.70 & Mechanical pulping \\
\hline 3.70 & Waste paper characterization (subsequently, excanded to oulp siber characterization) \\
\hline 3.60 & Paper drying using mach air nozzle \\
\hline 3.55 & Computer applications to energy management \\
\hline 3.50 & Batch-digester heat reuse \\
\hline 3.50 & Waste-paper recycling \\
\hline 3.50 & Bark separation from chips \\
\hline 3.45 & High-consistency forming \\
\hline 3.35 & Dry forming \\
\hline 3.35 & Microwave drying \\
\hline 3.30 & Fluidized bed \\
\hline 3.10 & Energy management handbook \\
\hline 3.05 & Puip washing \\
\hline 3.00 & Hydropyrolysis \\
\hline 3.00 & Reuse of low-value heat :o heat chips \\
\hline 2.90 & Pulp pressing \\
\hline 2.65 & New recovery rechnology \\
\hline 2.55 & Clean-ourning bark burners \\
\hline 2.25 & Rankine and electric heat pump \\
\hline 2.25 & Solid waste disposal \\
\hline 2.25 & Rerzoiant recuperator \\
\hline 2.15 & Technical information \\
\hline 2.15 & Gasifier \\
\hline 2.15 & Frzeze irystallization oi black liquor \\
\hline 2.05 & Pressurized fluidized bed \\
\hline 2.05 & Resource recovery iogistics \\
\hline 1.95 & Reduce water io recovery oviier \\
\hline 1.30 & Vechanical dewatering \\
\hline 1.20 & Memorane technology ior air znrichment \\
\hline 1.20 & Cual-serived ve!s for comoined gas jieam :uroines \\
\hline 1.30 & Alternaive iue!s ior :ime kilns \\
\hline
\end{tabular}




\section{Exhibit 8.3}

\section{DOE-Supported Technologies Not Included in Set of Candidate Technologies for Immediate DOE Implementation Actions}

DOE-Supported Technology
Cogeneration
Corrosion-resistant economizers
Paper-drying using mach nozzle
High-consistency forming

Microwave drying

Hydropyrolysis

Rankine and electric heat pump

Reradiant recuperators

Freeze crystallization of black liquor

Mechanical dewatering
Primary Reason for Not Including

DOE is already conducting major programs related to cogeneration implementation.

There is no known supplier of the special metallurgical materials needed.

Technical problems currently being encountered may prevent implementation of the mach nozzle before 1985.

The new design of the high-consistency forming headbox has not been tested in actual operating conditions. The resulting perception of nigh technical risk would likely delay market introduction beyond 1985 .

Health and safety standards for a high-energy microwave system operated in proximity to mill workers will impose design and operating constraints that will probably delay implementation a number of years.

Uncertainty regarding project economics in a joint demonstration between government and industry will probably delay implementation beyond 1985.

Scale-up of available heat pump designs to a size and reliability appropriate for incustrial applications is expecied to delay implementation. Currently available heat pumps have limited application in the pulp and paper industry.

Reradiant recuperators have been designed primarily for high-iemperature applications such as an aluminum remelt furnace. Units suitable for the sulp and paper industry are not expected to be commercially available by 1985 .

Technical feasibility issues, questionable economics, anc a possible thermal pollution problem all indicate long-term implementation prospects (6-7 vears).

Translation of mathematical modeling resulis into useful hardware is not likely to occur in the near ierm. 


\section{Exlitbic 8.4}

\section{Factors Considered in Market Analysis}

\begin{tabular}{|c|c|c|c|}
\hline & Market Segmentation Factors & Technical Market Factors & Economic Market Factors \\
\hline 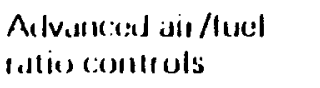 & - Boiler luel & - Boiler fuel & - Builer sice \\
\hline 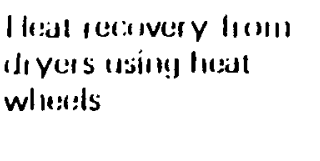 & $\begin{array}{l}\text { - Parker mills } \\
\text { - Papribuard mills }\end{array}$ & $\begin{array}{l}\text { - Higher basis-weight products } \\
\text { - Trine of diver houd } \\
\text { - Paper machines will upen } \\
\text { or closed hoods }\end{array}$ & $\begin{array}{l}\text { - Degree ol hood enclosing } \\
\text { - Puper muchine calpascily }\end{array}$ \\
\hline 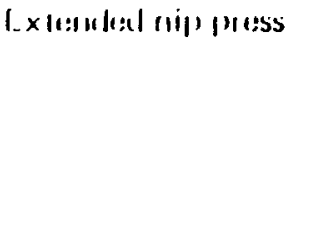 & $\begin{array}{l}\text { - Paper mills } \\
\text { - Paperboard mills }\end{array}$ & 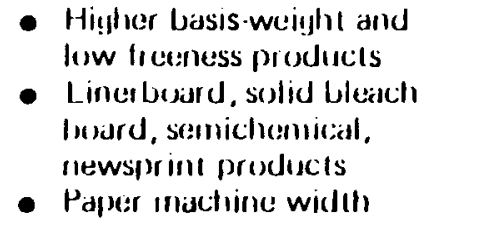 & $\begin{array}{l}\text { - Papmer machine capacity } \\
\text { (si<e, speed, basis } \\
\text { weighil) }\end{array}$ \\
\hline $\begin{array}{l}\text { L nen !ly mandgemenll } \\
\text { syslcins }\end{array}$ & $\begin{array}{l}\text { - Multiple-boriler fower } \\
\text { plarlss }\end{array}$ & - Number of boilers & $\begin{array}{l}\text { - Power plant configuration } \\
\text { (boilers, turbines, cogyenter } \\
\text { ation) } \\
\text { - Tolal stean production }\end{array}$ \\
\hline 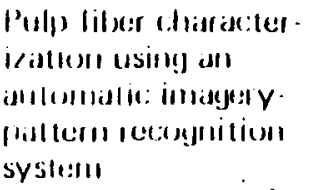 & - Pulp rinills & $\begin{array}{l}\text { - Pulping nrocess } \\
\text { (imecthanical, thermo- } \\
\text { mechanicial, and krafi) }\end{array}$ & $\begin{array}{l}\text { - Oisantily of pulp } \\
\text { prosluced } \\
\text { - Number ul pulping units }\end{array}$ \\
\hline
\end{tabular}

வு

Factors Considered in Market Analysis 
Exhibit

Energy Savings from

Advanced Air/Fuel Ratio Controls

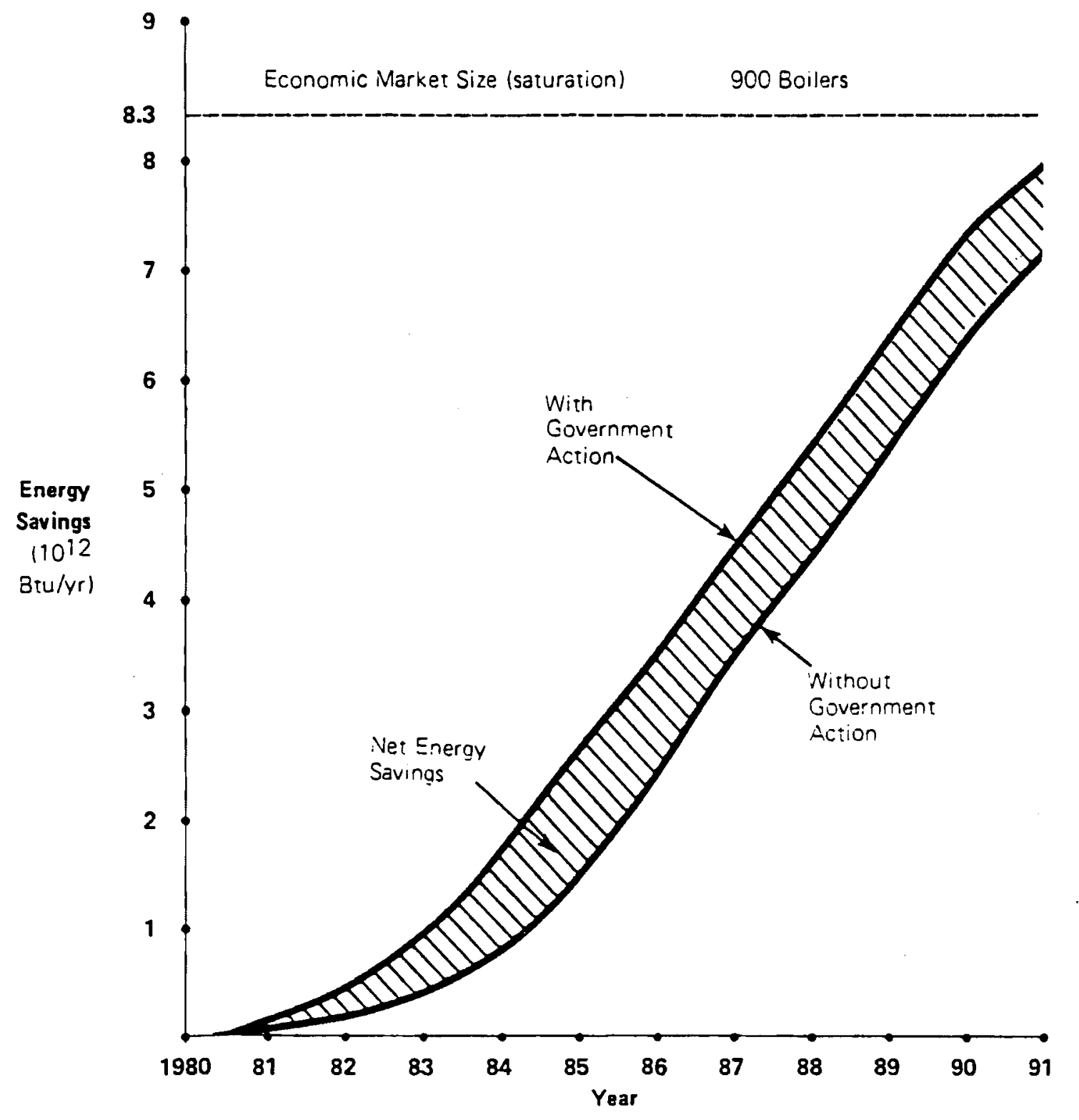


Exhibit C. 4

Energy Savings from Heat Wheels

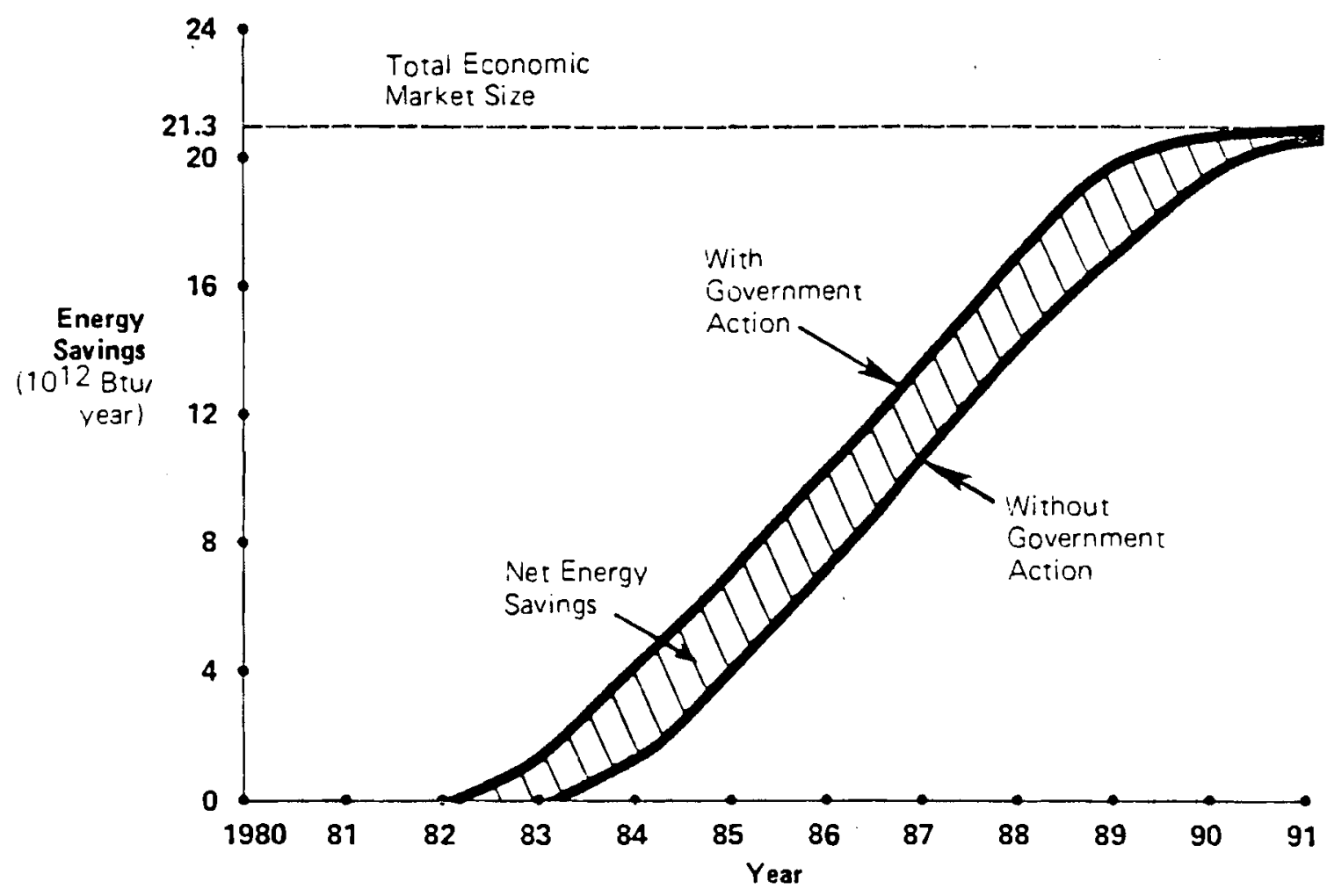


Exhibit C.10

Energy Savings from the Extended Nip Press

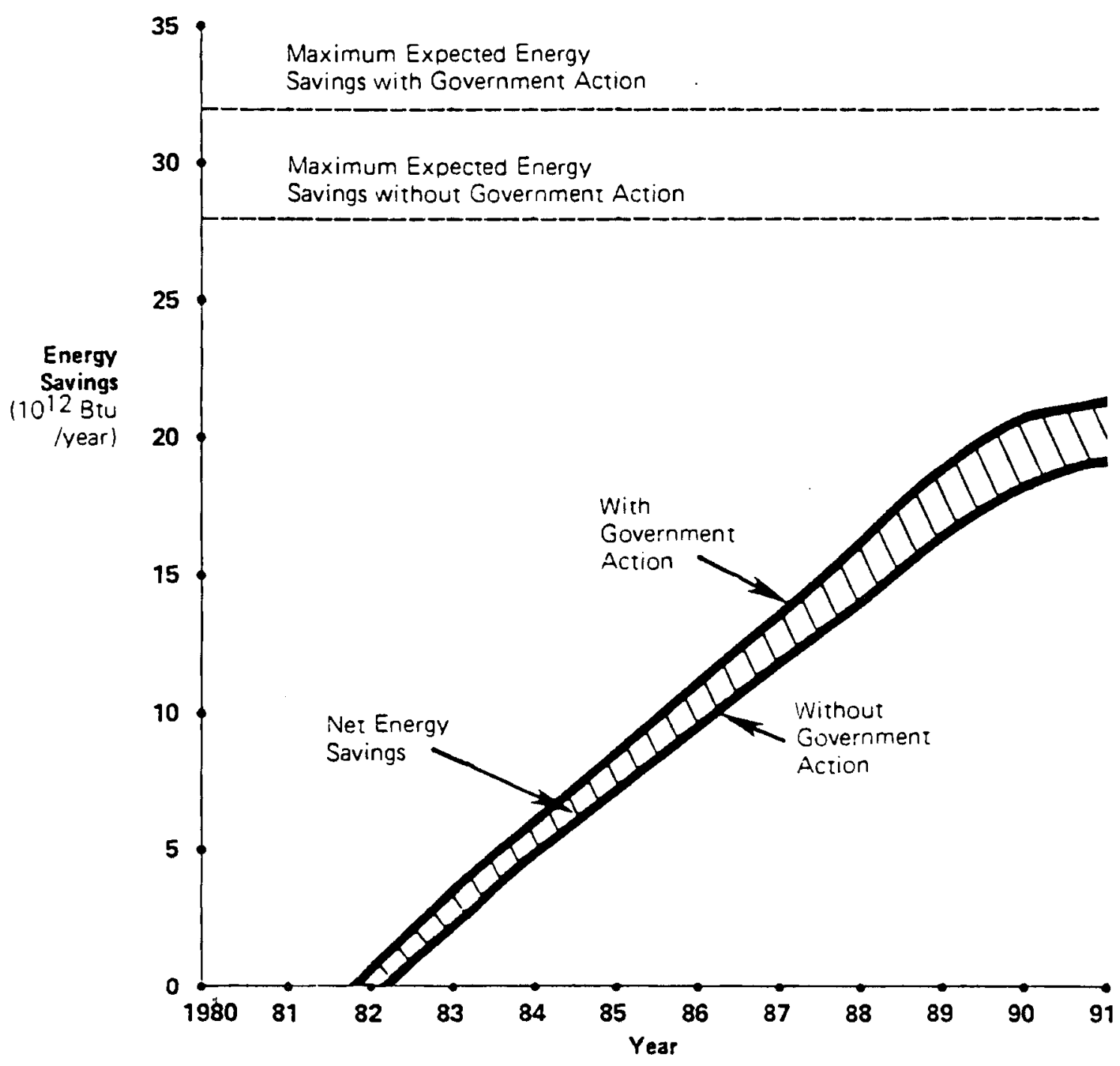




.

, 
- $\quad$ Report №. 36

I. Ross, Marc H., Williams Robert H. Our Energy: Regaining Control, McGrawHill, New York, 1981.

- independent funding sources

II. Technical and/or End-Use Focus

End-Use Orientation - focus on residential housing, industrial cogeneration, and automobile transportation.

III. Types of Information Provided

1. Fairly detailed review of gross energy consumption and market sizes (e.g. \# houses in year 2000) were given.

2. Maximum potential energy savings were calculated for each sector, but energy savings from specific R\&D were not identified.

3. No estimates of times to commercialization were given.

4. No review of existing research programs was made.

5. A systematic methodology was inherent in this study. Overall energy consumption patterns were examined to identify the three areas of primary concentration noted in (II.) Also, a second-law approach was used to identify areas of large potential savings and to justify efforts in particular areas.

IV. R\&D Opportunities

(1) Develop Hydraulic Transmission Systems to replace less efficient mechanical drives in machine power tools. ( $p$. 198)

- Would result in $20 \%$ savings in energy use in machine power tools.

- References:

J. Chase, NJD Lucas, W. Murgatroyd, "Industrial Energy Use - I: Power Losses in Electrically Driven Machinery", p. 179-196, Energy Research, Vol. 2, 1978.

N. Ladomatos, NJD Lucas, W. Murgatroyd, "Industrial Energy Use - II: Energy Use in a Light Engineering Factory," p. 375-388, Energy Research, Vol. 2, 1978.

N. Ladomatos, NJD Lucas, W. Murgatroyd, "Industrial Energy Use - III: The Prospects for Providing Motive Power in a Machine Tool Shop from a Centralized Hydraulic System," p. 19-28, Energy Research, Vol. 3, 1979.

(2) Develop Alternating Current Synthesizer for improving efficiency of industrial motors (p. 198).

- Would produce $50 \%$ savings in electricity used in industrial electric motors.

- References 
D. J. BenDaniel, E. Z. David Jr., "Semiconductor Alternating Current Motor Drives and Energy Conservation, Science 206, November 16, 1979, p. 773.

(3) Heat Transfer in Turbulent Flow (p. 220)

- References:

Efficient Use of Energy, A Physics Perspective, Vol. 25, American Institute of Physics Proceedings, 1975.

Jerry Grey, George W. Sutton, Martin Zlotnick, "Fuel Conservation and Applied Research," Science 200, p. 135, April 14, 1978.

Marc H. Ross, Robert H. Williams, "The Potential for Fuel

Conservation," Technology Review, February 1977, p. 48.

(4) Thermal Response of Buildings of Various Materials to Changing Weather Conditions ( $p .220)$.

- References:

Same as item (3).

(5) Friction and Lubrication (p. 220).

- References

Same as item (3).

(6) Air Drag on Surface Vehicles

- References:

Same as item (3).

V. Critical Summary

The Ross and Williams book is much more than an R\&D opportunities study. It devotes a gocd deal of effort to non-technical issues affecting energy conservation. This broadness of perspective gives the study's treatment of R\&D opportunities (albeit brief) a sense of realism. By carefully examining energy flows, demographic shifts, and degrees of saturation for various products, the authors make a plausible assessment of the overal! role that energy conservation can occupy in future energy strategies. Indeed, because of their pessimistic evaluation of the potential for customary estimates of energy demand in the future to be met by either nuclear or solar technologies, energy conservation is the cornerstone of the energy policy recommended by the authors. However, while this study sets the stage for R\&D opportunities assessment exercises, it does not complete the task. As can be seen from the R\&D opportunities that are listed in Section IV, a great deal of additional specification is necessary to justify the R\&D opportunities that were suggested by the authors. 
IV. Comments

This study should be read with the AIP study and the Ross and Willi ams Technology Review paper that are cited in item (3) in Section IV. In essence, the three pieces are a part of an overall study of energy conservation energy savings (potential and R\&D opportunities).

Reviewed by WJH. 


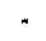


- $\quad$ Report No. 37

I. Schurr, Sam H., et.al. Energy in America's Future: The Choices Before Us, Johns Hopk ins University Press, Baltimore, 1979.

- research by Resources for the Future, funding at least partially from the Ford Foundation.

II. Technical and/or End-Use Focus

End-use orientation with focus on three segments of national energy use: residential space heating (about 10 percent of $U$. S. consumption), automotive transport (between 13 and 14 percent) and industrial process steam (about 10 percent).

III. Types of Information Provided

1. Study takes a very broad view of national energy use. Although formal justification of the three areas of concentration is not made, they appear sensible in light of the earlier discussions in the report, particularly in Chapter 2.

2. Energy savings are estimated only in broad terms. Savings are the result of a variety of research concepts, as well as public policy measures.

3. No estimates of times to commercialization are given, although many of the technologies considered are essentially available now and are simply in need of appropriate application.

4. No review of existing research programs was made.

5. An explicit methodology was not given in this study, but it did discuss the role of second law efficiencies and did review end use energy flows, making it more than a simple "laundry list."

IV. R\&D Opportunities

Residential Space Heating

- Efficiency of heating system could be cost-effectively improved by 20 percent (from 55 to 69 percent thermal efficient) Measures include:

(1) Electric Pilot for Gas Furnace (p. 130).

- Saves 6 million Btu/yr or about $5 \%$ of space heating energy.

- Some already available.

(2) Flue Damper for Gas Furnace (p. 130).

(3) Study of Air Infiltration (p. 131).

(4) Specially coated windows to inhibit radiative transfer (p. 131).

- Some already on market.

(5) Movable Window Insulation (p. 131). 
(6) Air to Air Heat Exchangers for Introducing Fresh Air (p. 131).

- Already in use in Sweden.

(7) Zoned Temperature Control (p. 131).

- Already in use to a small extent.

(8) Improved Heat Pumps (extraction of heat $f$ rom water and use of combustible fuel instead of electricity) (p. 131).

(9) Cogeneration (p. 131): correct e/s ratio, down-scaling.

- Can save as much as 30 percent of "base" fuel use.

(10) Solar Heating: economics, s eas onal storage, solar cogeneration of heat and electricity (p. 132).

(11) Passive Solar (p. 132).

(12) Integrated Appliance Use to Serve Multiple Applications (e.g. internal venting of dryer to provide heat) (p. 132).

Automotive Transport

(1) Electric Vehicles (1ightweight batteries and materials) (p. 197).

(2) Substitution of Communications for Travel (p. 198).

(3) Crashworthiness of Small Autos (p. 155).

- DOT Highway Traffic Safety Administration Program is performing research.

* However, report concludes that automotive R\&D is advancing at a pace which suggests that no bold policy initiatives are required. The goverment should not be involved in demonstration of technologies. Specifically, the government should not support efforts at engineering to improve automobile engine design. (p. 977).

Industrial Process Steam

Coge nerati on $\star \star$

(1) Fluidized Bed Combustors (including residential scale) (p. 165).

- References

A. B. Lovins, Soft Energy Paths, Harper 1977, pp. 46-48.

(2) Coal Fired Gas Turbines (p. 165).

(3) Coal-Fired Diesel Engines (p. 165).

(4) Coal-Fired Stirling or Ericsson Engi nes (p. 16). 
**The need for these technologies arises from the fact that generation technology with high electricity-to-steam ratios is not ready to use coal as a fuel. Cogeneration is more economical with high e/s ratios, provided industry can sel1 excess electricity ( $p$. 170).

General R\&D Opportunities

(1) Reduction of Friction Research (Tribology): broad application ( $p$. 477).

V. Critical Summary

The RFF Study is a massive, information-packed energy study that offers a wealth of useful data for performing energy analyses. However, it is not primarily an R\&D needs study. Where R\&D opportunities are discussed, they are generally peripheral to discussions of policy or the appropriate role for government. Also, the discussions of R\&D are plainly taken from the work of Ross and Williams and one might as well get these results direct from the horse's mouth by reading Ross and Williams' book and the AIP study. This does not mean that the RFF study is not useful in studying R\&D opportunities. On the contrary, the study goes a long way toward establishing the context for an R\&D opportunities study through its review of end-use energy consumption and discussions of non-technical barriers to energy conservation. The following list of non-technical barriers to residential energy conservation is crucial to market penetration and ultimate conservation potential of any residential conservation technology.

\section{Residential Conservation Barriers}

1. Conservation equipment is purchased by builders rather than homeowners.

2. Building codes are often based on specifications rather than performance.

3. Building industry has low capitalization and is therefore sensitive to first cost rather than life cycle cost.

4. Building industry is fragmented and horizontally stratified.

5. Building industry is craft oriented and resistant to change.

6. Feedback to residents is slow and difficult to interpret.

7. Dweller often does not directly pay utility bills.

8. Variety of buildings makes retrofits hard to standardize.

9. Conservation is generally compared to average energy costs rather than social replacement of marginal costs.

VI. Comments

This book is complementary to the work of Ross and Williams (indeed it was based on it). Reading them together gives good coverage to the areas of residential space heating, auto transport, and industrial process steam, although both stop short of a really thorough technical analysis of R\&D opportunities in these areas.

Reviewed by $W J H$ 

- $\quad$ Report No. 38

I. Stephens, J. R., W. R. Witzke, G. K. Watson, J. R. Johnson and W. J. Croft. Materials Technology Assessment for Stirling Engines. NASA TM-73789. NASA Lewis Research Center, Cleveland, Ohio, 1977.

II. Technical and/or End-Use-Focus

Assesses current state of the art of metals and ceramic with respect to Stirling engine and recommends materials R\&D programs needed.

III. Types of Information Provided

1. No energy and use data were reviewed.

2. No energy savings were estimated.

3. No time to commercialization estimates were made.

4. Existing research was not reviewed.

5. Engine design temperatures and stresses and related to existing material properties to point out needed areas of data development and property improvements.

IV. R\&D Opportunities

(1) Improved (Metal) Engine ( $p p .3-6$ ) - The heater head is the most critical component. Mechanical property data and required for candidate alloys under anticipated engine operating conditions. Hydrogen compatibility, permeation, and effects on properties need to be measured for uncoated and coated alloys. Lower costs, nonstrategic alloys need to be substituted.

- References 3 thru 12 attached.

(2) Advanced (Ceramic) Engine (pp. 748) - A paucity of data on candidate ceramic materials under estimated engine operating conditions exists. Because of its high temperature the air preheater is considered to be the most critical component. "Long term stability data at the air preheater temperature and long-term mechanical property data under operating conditions of the heater head are needed. Environmental effects (hydrogen and combustion gases) must be evaluated. Low cost fabrication technology must be developed for the various ceramic components - - in the advanced Stirling engine.

- Reference 5 of attachment.

V. Critical Summary

This is a summary paper with a low level of detail but a few good sounding references on the details of Stirling engine design. Economic and competitive (with respect to other engines) analysis not included. Justification of needed R\&D apparently assumed.

VI. Comments

A good, basic reference for materials work required for Stirling engines. 


\section{References}

1. Ragsdale, R. G.: Stirling Engine Project Status. ERDA Highway Vehicle Systems Contractor Coordination Meeting Held in Dearborn Mich., Oct. 4-6, 1977 .

2. Should We Have a New Engine? An Automobile Power Systems Evaluation. Jet P ropul si on Laboratory, JPL-SP 43-17, Vols. I and II: SAE-SP-399 and SAESP $-400,1975$.

3. Blankenship, C. P,; and Schulz, R. B.: Opportunities for Ceramics in the ERDA /NASA Continuous Combusti on Propul si on Systems Program. NASA TM $X-73597,1977$.

4. Postma, Norman D.; Van Giessel, Rob; and Reinink, Frits: The Stirling Engi ne for Passenger Car Application. SAE paper 730648, Sept. 1973.

5. Tomazic, William A.; and Cairelli, James E.: Ceramic Applications in the Advanced Stirling Automotive Engine. NASA TM X-73623, 1977.

6. van Beukering, H.C. J.; and Foller, H.: Present State of-the-Art of the Philips Stirling Engi ne. SAE paper 730646, June 1973.

7. Commodity Data Summaries, 1977: Bureau of Mines, U. S. Department of the Interior, 1977.

8. Shewmon, P. G.: Hydrogen Attack of Carbon Steel. Effect of Hydrogen on Behavior of Materials, A. W. Thompson and I. M. Bernstein, eds., AIME, 1976 , pp. 59-69.

9. Nel son, Howard G.; and Stein, James E.: Gas-Phase Hydrogen Permeation Through Alpha I ron, 4130 Steel, and 304 Stainless Steel from Less than $100 \mathrm{C}$ to near $600 \mathrm{C}$. NASA TN D-7265, 1973.

10. Louthan, M. R., Jr.; and Caskey, G. R., Jr.: Hydrogen Transport and Embrittlement in Structural Metals. Int. J. Hydrogen Energy, Vol. 1, 0ct. 1976, pp. 291-305.

11. Harris, J. A., Jr.; and Van Wanderham, M. C.: Properties of Materials in $\mathrm{High}$ Pressure Hydrogen at $\mathrm{Cryogeni}$, Room, and Elevated Temperatures.

(FR- 5768, Pratt and Whitney Aircraft; NASA Contract NAS8-26191.) NASACR-1243 94, 1973.

12. Kl ima, Stanley, J.; Nachtigal, Alf red J.; and Hoffman, Charles A.: Prel iminary Investigation of Effect of Hydrogen on Stress-Rupture and Fatigue Properties of an Imn-, a Nickel-, and a Cobalt-Base Alloy. NASA TN D-1458, 1962.

Reviewed by WEG. 


\section{B.3 BIBLIOGRAPHY OF ENERGY CONSERVATION RESEARCH OPPORTUNITIES}

- 1. A.D. Little, Inc. Environmental Considerations of Selected EnergyConserving Manufacturing Process Options. Vo 1. X. Cement Industry Report. EPA-600/7-76-034j. U.S. Environmenta 1 Protection Agency, Cincinnati, Ohio. 1976.

- 2. A.D. Little, Inc. RD\&D for Energy Conservation Preliminary Identification in Iron and Steelmaking. SAN/1692-1. Divis ion of Industrial Energy Conservation, U.S. Department of Energy, January 1978.

- 3. Aerodyne Research, Inc. An Assessment of the Potential Impact of Combustion Research on Internal Combustion Engine Emissions and Fue 1 Consumption. PB-0290953. Aerodyne Research, Inc. Bedford, MA, January 1979.

4. Aerospace Corp. Light-Duty Diesel Engine Development Status and Engine Needs. The Aerospace Corporation, August 1980.

- 5. American Institute of Physics. Efficient Use of Energy: AIP Conference Proceedings No. 25. American Institute of Physics, New York, 1975.

6. American Society of Mechanical Engineers. Heat Transfer in Energy Conservation. Heat Transfer Division, Energetic Division, November 27 December 2, 1977.

- 7. American Society of Mechanical Engineers. Research Needs Report:

Environmental and Conservation Research, American Society of Mechanical Engineers Task Force on Environmental and Conservation Research, American Soc iety of Mechanical Engineers, New York, 1979.

- 8. American Society of Mechanical Engineers. Research Needs Report: Fundamental Research Needs. Amer ican Society of Mechanical Engineers Task Force on Fundamental Research, American Society of Mechanical Engineers, New York, 1978.

- 9. Anderson, Car 1 J. Research and Development Needs for Transportation, Lawrence Livermore Laboratory, Apri1 10, 1975.

10. Bahadar, S. "Near Research and Development", J. Lubr. Tech., Trans Asme, V. 100 , n. 4, October 1978, p. 449-454.

- 11. Battelle Columbus Laboratories. Developing a Maximum Energy Efficiency Improvement Target for SIC 28: Chemicals and Allied Products. Vo 1. 1. PB269869. Battelle Columbus Laboratories, Columbus, OH, July 1976.

- 12. Battelle Columbus Laboratories. Implementation of Energy Conservation Technology in the Steel Industry. Vols. I and II. Battelle Columbus Laboratories, Columbus, OH, August 1980.

- 13. Berg, Char les A. Energy Conservation in Industry: The Present Approach, The Future Opportunities. Counc 11 on Environmental Quality, May 1979.

- 14. Brookhaven National Laboratory. Future Raw Materials and Energy Use in Industry - A Research Agenda. A workshop sponsored by the Division of Industrial Energy Conservation, U.S. Department of Energy (DOE), November $9-10,1978$. 
15. Burte, Wilfred J. Possible Energy Savings With the Help of Tribology, Especially in the Case of Motor Vehicles. Tech. Akad EssTinjen, Ger. (Erdoel Kohle Erdgus Petrochem Ver Brennst Chem V33 N. 2 Feb. 1980, p. 78-87).

16. Chakrabarty, A.M. "Which Way Genetic Engineering?" Industrial Research, Jan. 1976, pp. 45-50.

17. Cheng, H.S. List of Theses Topics in Tribology. American Society of Mechanical Engineers Publication, n. 76-Lub-G, 1976.

- 18. Committee on Nuclear and Alternative Energy Systems. Energy in Transition 1985-2010. National Academy of Sciences, Washington, D.C., W.H. Freeman: San Franc isco, 1979.

- 19. Cremers, C.J. "Environmental and Conservation Research Needs in the Eighties", American Society of Mechanical Engineers Publication 76-WA/RGPC-2. American Society of Mechanical Engineers, New York, 1976.

20. Department of Energy. Cogeneration: Technical Concepts, Trends, Prospects, DOE-FFU-1703. Department of Energy, Washington, D.C., September 1978 .

- 21. Department of Energy. Department of Energy Program Objectives, Fluid Waste Heat Recovery and Utilization. TID-28393. Department of Energy, Washington, D.C., February 1978.

- 22. Department of Energy. Report of the Proceedings of the DOE Workshop on Energy Conservation in the Textile Industry. TIC-10007. Division of Industrial Energy Conservation, Department of Energy, January 24 and 25, 1978.

- 23. Department of Energy. Research Workshop on Energy Conservation Through Enhanced Heat Transfer. C00-4649-8. U.S. Department of Energy, October 1979.

24. Dufek, V. Tribology Consolidates its Position. Rept. No. FTD-HC-23-148871. Foreign Tech. Div., Wright-Patterson AFB, 1971.

- 25. Energy Research and Development Administration. Agriculture Processing Industry Workshop on Energy Conservation. CONF-760355. Division of Industrial Energy Conservation, Energy Research and Development Administration, Washington, D.C., March 4-5, 1976.

- 26. Energy Research and Development Administration. ERDA Workshop on Energy Conversion in Agriculture Production. CONF -760763. Energy Research and Development, Washington, D.C., JuTy 15-16, 1976.

- 27. Energy Research and Development Administration. ERDA Workshop on Fluid Waste Heat Recovery and Utilization. CONF-761157. Division of Industrial Energy Conservation, Energy Research and Development Administration, Washington, D.C., November 17-19, 1976.

- 28. Energy Research and Development Administration. ERDA Workshop on High Temperature Waste Heat Recovery and Utilization. Division of Industrial Energy Conservation, Energy Research and Development Administration, Washington, D.C., August 25-26, 1977. 
29. Energy Research and Development Administration. A Federal Look at the Needs for Energy-Related Materials Research and Development. ERDA 76-28VI (Prelim. Version), ERDA Tech. Info. Center, Oak Ridge, TN. (Vol. 2 Intermediate and Long-Term Program appeared as a draft but apparently never was officially published). 1976.

30. Energy Research and Development Administration. Industrial Applications Study, Vol. III, Technology Data Base Evaluation of Waste Recovery Systems. C00-2862-3. Energy Research and Development Administration, Division of Conservation Research and Technology, Washington, D.C., January 1977.

31. Energy Research and Development Administration. Materials Sciences Overview, Vol. II Workshop Reports. ERDA 77-7672. Energy Research and Development Administration. NTISD, Springfield, VA, 1977. (Vol. 1 of this is an Executive Summary).

- 32. Energy Task Group, Committee on Materats (COMAT), Federal Council for Science and Technology, Needs for Energy-Related Material Research and Development. Vo . 1. Near Term Energy Program. ERDA 76-28VI, NTIS, Springfield, VA, 1976.

- 33. The Engineering Societies Commission on Energy (ESCOE). Basic Research in Engineering, Advanced Industrial Technology. FE-246 $\overline{8-56}$. Department of Energy, Washington, D.C., February 1979.

- 34. The Engineering Societies Commission on Energy (ESCOE). in Engineering, Fluid Dynamics and Thermal Processes. FE-2468-54. Department of Energy, Washington, D.C., August 1979.

35. Fox, J. L. "Biological Solutions to Industrial Energy Reduction," presented at the 1981 IECTC. Houston, TX, April 26-29, 1981.

36. General Electric Corporation. Cogeneration Technology Alternative Study Summary Report. Vol. 1. DOE/NASA/0031-80/1. Prepared for NASA-Lewis, Cleveland, $\mathrm{OH}$, April 1980.

37. General Electric Corporation. Cogeneration Technology Alternative Study Industrial Processes. Vol. 3. DOE/NASA-0031-80/3. Prepared for NASALewis, Cleveland, OH, April 1980.

38. General Energy Associates, Inc. Relevance of the Second Law of Thermodynamics to Energy Conservation. Vols. I and II. DOE/CS/40178. 000-01. National Bureau of Standards, Cherry Hill, NJ, January 1980.

- 39. Georgia Institute of Technology. Energy Conservation in the Paper and Allied Products Industry, Phase 1. DOE/CS/40098-T1. Department of Energy, Washington, D.C., October 1979.

40. Gordian Associates. Heat Pump Technology. HCP/M2121-01. Buildings and Community Systems Division, U.S. Department of Energy, June 1978.

- 41. Gordian Associates. IEA Steel R\&D Report, Final Report. AL0-5076-TI. May 31, 1979. 
42. Gorman, R. and K. L. Heitner, "A Comparison of Costs for Automobile Energy Conservation versus Synthetic Fuel Production," presented at the 5th International Automobile Propulsion Systems Symposium, April $14-18,1980$.

- 43. Grey, Jerry, Sutton, George W. and Zlotnick, Martin. "Fuel Conservation and Applied Research," Science 200. No. 4338, April 14, 1978, pp. 13542 .

44. Haines, L. F. and G. R. Morley, "Lubricant Development on British Rail," Proceedings of Institute of Mechanical Engineers. Vol. 192, December 1978, p. 333-342.

45. Halling, J. Tribology in Manufacturin Engineering. Institute of Mechanical Engineers (Cond.), Proc. v. 192, June 1978, p. 189-196.

- 46. Hollander, Jack M. Basic Research Needs in Energy Conservation. LBL-99939. Lawrence Berkeley Laboratory, University of California, October 1979.

47. Ivkovic, B. Z. "Tribological Characteristics of Cutting Fluids and Machining Costs," 2nd International Conference on Lubricating Challenges in Metalworking and Processing. IIT Research Institute, Chicago, IL, June 27-29, 1971.

48. Jet Propulsion Laboratory. Should We Have a New Engine, An Automobile Power Systems Evaluation. Pasadena, CA, August 1975.

- 49. Johnson, R. M. Tribology: Research and Development Needs in Advanced Energy Technology. (REPT NO: CONF-770237-1) HEDL SA-1191. Hanford Engineering and Development Laboratory, Richland, WA, 1977.

50. Jost, H. Peter. Economic Impact of Tribology. National Bureau of Standards Specifications Publication, 423, April 1976.

- 51. Klaus, E. E. "Energy Conservation in Road Transportation Through Lubrication Technology," Lubrication Engineering. Vol. 34 n. 11, November 1978, pp. 611-617.

52. Ku, P. M. "Energy and Materials Conservation Through Tribology," Lubrication Technology. Vol. 34, n. 3, March 1978, pp. 131-134.

53. Larsen, R. M. "Tribology: The Little known Science of Friction and Wear," Iron Age. v. 221, n. 44, November 1978, pp. 51-54.

- 54. May, E. Kenneth and Hooker, Douglas W. Reducing Fuel Usage Through Applications of Conservation and Solar Energy. SERI/TP-733-665, April 1980.

55. McDonald, C. F. "The Role of the Ceramic Heat Exchanger in Energy and Resource Conservaation," Journal of Engineering for Power. Vo1. 102, April 1980, pp. 303-315.

56. McNab, I. R. "Recent Advances in Electrical Current Collection," Wear. Vo 1. 59, n. 1, March 1980, pp. 259-a276. 
57. Miller, H. R. New Lube 0ils and Fuel Economy. (Edwin Cooper, Inc.) Proc., American Petroleum Institute, Refining Department: 71. 73(1978).

58. Miller, P., et. al. Plastic Heat Exchangers: A State-of-the-Art Review. ANL-79-12. Prepared by Argonne for the Department of Energy, Washington, D.C., July 1979.

- 59. MITRE Corporation. An Agenda for Research and Development on End-Use Energy Conservation. Volumes I and II Mtr-6577. McLean, VA, December 1973.

60. Mujumdar, Arun. Drying '80. Vo1. I \& II. Hemisphere Press, Washington, D.C., 1980.

61. NASA-Lewis. Cogeneration Technology Alternative Study (CTAS), Summary. Vo 1. 1. DOE/NASA/1062-80/4. Prepared for DOE, Washington, D.C.,

62. Newcomb, T.P. "Energy Dissipated During Braking", Wear. Vo1. 59, n. 2, March 1980, pp. 401-407.

63. O'Callaghan, Pau1. Energy for Industry. Pergamon Press, Oxford. 1979.

64. Office of Technology Assessment. Changes in the Future Use and Characteristics of the Automobile Transportation System. GPO, Washington, D.C., February 1979.

65. Office of Technology Assessment. Impact of Advanced Air Transport Technology, Part 1: Advanced High Speed Aircraft. GPO, Washington, D.C., Apri1 1980.

66. Office of Technology Assessment. Impacts of Applied Genetics: Microorganisms, Plants, and Animals. GP0, Washington, D.C. April 1981.

- 67. Office of Technology Assessment. Residential Energy Conservation. Volume I, Office of Technology Assessment, Washington, D.C., 1978 est. (No date given).

68. Office of Technology Assessment. Technology and Steel Industry Competitiveness. Office of Technology Assessment, GPO, Washington, D.C. June 1980.

- 69. Oppenheim, A.K. and F.J. Weinburg. "Combustion R\&D - Key to Our Energy Future", Astronautics and Aeronautics. November 1974, pp. 22-31.

70. Perez-Blanco, H., and F.C. Chen. "Some Concepts for Residual Heat Remova1". Alternate Energy Sources Conference. CONF-801210-11, December 1980 .

71. Pinkus, Oscar, Donald F. Wilcock. "Role of Tribology in Energy Conservation, Lubr. Eng. V34, n. 11, November 1978, p. 599-610.

- 72. Pinkus, Oscar, Donald Wilcox. Strategy for Energy Conservation Through Tribology, Pub1. by ASME, $197 \overline{7}$. 
73. Plevy, T.R.H. "The Role of Friction in Metal Working With Particular Reference to Energy Savings in Deep Drawing," Patterns of Tribology. Vol. II, p. 361-379 (also in Wear, Vol. 58 n. 2, p. 359-380, Feb. 1980).

- 74. Resource Planning Associates. Implementation of Energy Conservation Technology in the Paper and Pulp Industry. Department of Energy, Washington, D.C., September 1980.

75. Resource Planning Associates. Technical Overview of Cogeneration: The Hardware, the Industries, the Potential Development. SAN-1223-TI. Resource Planning Associates, Washington, D.C., prepared for the Department of Energy, December 1977.

- 76. Ross, Marc H., Williams, Robert H. Our Energy: Regaining Control. McGraw-Hi11, New York, 1981.

- 77. Schurr, Sam H., et. al. Energy in America's Future: The Choices Before Us, Johns Hopk ins University Press, Baltimore, 1979.

78. Semler, T.T., et. al. Potential Industrial Applications for Direct Contact Waste Heat Recuperator Systems. EGFG-CS-5328. Prepared by EG\&G for Department of Energy, Washington, D.C., February 1981.

79. Solar Energy Research Institute, Committee on Energy and Commerce. Building a Sustainable Future. Vols. I, II . Committee Print 97-K, Washington, D.C., Apri1 1981.

80. Somasundaran, P. and D.W. Fuerstenau. Research Needs in Mineral Processing. PB-260735. Available from NTIS, Springfield, Va., 1976.

81. Steering Committee for the Study of Research Applied to Naional Needs. Priorities for Research Applicable to National Needs. National Academy of Engineering, Washington, D.C. 1973.

- 82. Stephens, J.R., W.R. Witzke, G.K. Watson, J.R. Johnson, W.J. Croft. Materials Technology Assessment for Stirling Engine. NASA TM-73789. NASA Lewis Research Center, Cleveland, Ohio, 1977.

83. Szekely, Julian. "Radically Innovative Steelmaking Technologies," Howe Memorial Lecture, Metallurgical Transaction B. Vol. 11B, September 1980, pp. 353-371.

84. Tribological Consideration in the Hot Rolling of Low Carbon Steel, (Author, etc., unknown.)

85. TRW. Program Plan Report for Allied Research in Road Vehicles. Energy Systems Group, TRW, July 29, 1977.

86. United Technologies Corp. Cogeneration Technology Alternative Study Summary Report. Vol. 1. DOE/NASA/0030-80/1. Prepared for NASA-Lewis, Cleveland, $\mathrm{OH} .$, January 1980.

87. United Technologies Corp. Cogeneration Technology Alternative Study Energy Conversion System. Vo1. 3. DOE/NASA/0030-80/3. Prepared for NASA-Lewis, Cleveland, OH, January 1980.

88. Westinghouse. Industrial Cogeneration Optimization Program. Vol. 1. DOE/CS/05310-1. Department of Energy, Washington, D.C., January 1980. 


\section{DISTRIBUTION}

No. of

Copies

OFFS I TE

A. A. Churm

DOE Patent Division

9800 S. Cass Avenue

Argonne, IL 60439

27 DOE Technical Information Center

E. Karl Bastress

U.S. Department of Energy

Energy Conversion and

Utilization Division

1G-080 Forrestal Building

Washington, DC 20545

Michael D. Shapiro

U.S. Department of Energy

Energy Conversion and

Utilization Division

1G-080 Forrestal Building

Washington, DC 20545

James Eberhardt

U.S. Department of Energy

Energy Conversion and

Utilization Division

1G-080 Forrestal Building

Washington, DC 20545

Marvin Gunn

U.S. Department of Energy

Energy Conversion and

Utilization Division

1G-080 Forrestal Building

Washington, DC 20545

John Brogan

U.S. Department of Energy

Office of Energy Systems R\&D

Washington, DC 20545
No. of

Copies

\author{
Maxine Savitz \\ Deputy Assistant Secretary \\ of Conservation \\ U.S. Department of Energy \\ Washington, DC 20545 \\ Joseph A. Carpenter \\ Oak Ridge National Lab. \\ P.0. Box $X$ \\ Building 4508 N., Room 263 \\ Oak Ridge, TN 37830 \\ Jovan Mocanin \\ The Jet Propulsion Lab. \\ 4800 Oak Grove Drive \\ Mail Stop 122-123 \\ Pasadena, CA 91103 \\ Paul Massier \\ The Jet Propulsion Lab. \\ 4800 0ak Grove Drive \\ Mail Stop 122-123 \\ Pasadena, CA 91103 \\ William Thielbar \\ U.S. Department of Energy \\ Idaho Operations office \\ 550 Second Street \\ Idaho Falls, ID 83401 \\ Robert Holtz \\ Argonne National Lab. \\ Building 330 \\ 9700 South Cass Avenue \\ Argonne, IL 60439 \\ C. W. Robinson \\ Division $835 Z$ \\ Sandia Laboratories \\ P.0. Box 969 \\ Livermore, CA 94550
}


No. of

Copies

Dwain Diller

Continuous Process Technology Programs

National Bureau of Standards

325 S. Broadway

Boulder, CO 80303

D. L. Plymale

U.S. Department of Energy

Albuquerque Operations Office P.0. Box 5400

Albuquerque, NM 87115

Marc H. Ross

Physics Department

The University of Michigan

Ann Arbor, MI 48109

Yukio Nakamura

The Jet Propulsion Lab.

4800 0ak Grove Drive

Mail Stop 122-123

Pasadena, CA 91103

Char les Fink

Energetics, Inc.

2000 Century Plaza

Columbia, MD 21044

Howard Hagler

Hagler, Bailly \& Co., Inc.

$2020 \mathrm{~K}$ Street, N.W.

Suite 350

Washington, DC 20006

Dominic Monetta

Resource Alternatives, Inc.

1629 K Street, N.W.

Washington, DC 20006

Richard Silberglitt

DHR, Inc.

1055 Thomas Jefferson St. N.W.

Suite 414

Washington, DC 20009
No. of

Copies

Gabor Strasser

Strasser Associates, Inc. 2616 Pine Knot Drive

Vienna, VA 22180

Mart in V. Jones

Impact Assessment Institute

118 Monroe St., Suite 1311

Rockville, MD 20850

Thomas Bustard

Energetics, Inc.

2000 Century Plaza

Columbia, MD 21044

Stephen N. Bobo

Transportation Systems Center

Kendall Square

Cambridge, MA 02142

Robert E. Barrows

Starter Development

Ingerso 11-Rand Company

P.0. Box 7517

Roanoke, VA 24019

Robert G. Massey

Department of Energy

CE 122

1000 Independence Avenue

Washington, DC 20585

Dr. Richard P. De Filippi

Critical Fluid Systems, Inc.

25 Acorn Park

Cambridge, MA 02140

Stanley Sobczynski

Department of Energy

CE 122

1000 Independence Avenue

Washington, DC 20585

Chris Eagan

Concentration Specialists, Inc.

26 Dundee Park

Andover, MA 01810 
No. of

Copies

David Klimaj

Department of Energy

CE 122

1000 Independence Avenue

Washington, DC 20585

\section{Onsite}

DOE - Richland Operations

H. E. Ransom

99 Pacific Northwest Laboratory

F. W. Albaugh

W. B. Ashton (50)

R. S. Campbe 11

W. C. Cliff

S. D. Dah lgren

D. E. Deonigi

R. L. Dillon

J. E. Garnier
No. of

Copies

W. E. Gurwe 11 (5)

C. R. Hahn

G. J. Hane (10)

P. E. Hart

H. Harty

S. G. Hauser

B. M. Johnson

R. S. Kemper

R. S. Kemper

C. L. Mohr

L. T. Pedersen

L. D. Perrigo

R. P. Turcotte

0. J. Wick

T. A. Williams

R. E. Williford

T. L. Willke

Economics Library (5)

Publishing Coordination (2)

Technical Information Files HA (5) 


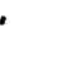

